\title{
Marília Normanton
}

Estudo da interação das células-tronco mesenquimais e linfócitos no modelo da doença do enxerto contra hospedeiro

Dissertação apresentada à Faculdade de Medicina da Universidade de São Paulo para a obtenção do título de Mestre em Ciências

Programa de Alergia e Imunopatologia

Orientadora: Dra. Luciana Cavalheiro Marti

São Paulo

2014 


\section{Marília Normanton}

Estudo da interação das células-tronco mesenquimais e linfócitos no modelo da doença do enxerto contra hospedeiro

Dissertação apresentada à Faculdade de Medicina da Universidade de São Paulo para a obtenção do título de Mestre em Ciências

Programa de Alergia e Imunopatologia

Orientadora: Dra. Luciana Cavalheiro Marti

São Paulo

2014 
Dados Internacionais de Catalogação na Publicação (CIP)

Preparada pela Biblioteca da

Faculdade de Medicina da Universidade de São Paulo

Creprodução autorizada pelo autor

\section{Normanton, Marília}

Estudo da interação das células-tronco mesenquimais e linfócitos no modelo da doença do enxerto contra hospedeiro / Marília Normanton. -- São Paulo, 2014.

Dissertação(mestrado)--Faculdade de Medicina da Universidade de São Paulo. Programa de Alergia e Imunopatologia.

Orientadora: Luciana Cavalheiro Marti.

Descritores: 1.Doença enxerto-hospedeiro 2.Transplante de medula óssea 3.Células-tronco adultas 4.Linfócitos T 5.Interleucina-7 6.Apoptose 7.Proliferação de células

USP/FM/DBD-139/14 
Aos meus queridos pais, Márcia e Percy, a quem serei eternamente grata por todo apoio, dedicação e amor. 


\section{AGRADECIMENTOS}

A Deus, pois nos momentos em que abandonar tudo parecia ser a saída mais fácil para todos os problemas, concedeu-me paz e força para seguir adiante.

Aos meus amados pais, Percy e Márcia, assim como ao meu irmão Guilherme, por terem me apoiado, pelo amor incondicional, pelo abraço nas horas difíceis, por acreditarem em mim, pelo carinho, por não medirem esforços para que eu concluísse essa etapa de minha vida e por não me deixarem desistir. Sem o amor e compreensão deles esse trabalho não teria sido alcançado.

À minha família, pelo amor e carinho de sempre e a quem dedico todas as minhas conquistas.

À minha orientadora, Dra. Luciana Cavarlheiro Marti, por acreditar no meu potencial, pelo apoio, inspiração no amadurecimento dos meus conhecimentos e conceitos que me levaram a execução e conclusão desta tese, por contribuir com o meu crescimento pessoal e profissional, e por ser um exemplo.

Às amigas, Heliene, Laiz e Suzana, agradeço pelo convívio, pela compreensão, amizade, pelas risadas e choros nas horas de desespero. Obrigada por permitirem que essa etapa fosse a mais divertida possível.

Obrigada aos amigos que tiveram paciência de entender minhas crises, em especial as amigas Tess Lynn e Paola, que mesmo de longe me apoiaram, acreditaram em mim. Agradeço pela força, pelo amor e por estarem ao meu lado sempre. Sem vocês, com certeza, teria sido impossível chegar até aqui.

Aos funcionários e alunos de pós-graduação do laboratório, em especial a técnica Marta Diniz, pela amizade e cuidado com os meus materiais.

Aos colegas do Laboratório do Instituto de Ensino e Pesquisa Albert Einstein, que direta ou indiretamente colaboraram para a conclusão desse trabalho. 
À Fundação de Amparo a Pesquisa do Estado de São Paulo e ao Instituto UNIEMP, pelo apoio financeiro para a realização do projeto, pelo interesse nesse assunto e pela bolsa de mestrado.

Ao Instituto de Ensino e Pesquisa Albert Einstein pelo espaço físico e equipamento de excelente qualidade.

À Faculdade de Medicina da USP, em especial ao departamento de Alergia e Imunopatologia, pelo espaço físico, pelo interesse no trabalho, pelas questões esclarecidas ao longo desses anos e por fazer de um sonho a realidade.

Agradeço a todos que acreditaram em meu potencial, na minha profissão, nas minhas ideias, nos meus devaneios e que direta ou indiretamente contribuíram com o desenvolvimento e conclusão deste trabalho.

Obrigada! 


\section{LISTA DE FIGURAS}

Figura 1 - Células T CD4+ antígeno-ativadas adquirem vários fenótipos determinados por citocinas e fatores de transcrição (82)

Figura 2 - Separador de células miniMACS (Miltenyi Biotec), utilizado na separação das células CD14+ (Fonte: http://www.miltenyibiotec.com) ........... 27

Figura 3 - Representação do modelo de controle positivo................................. 30

Figura 4 - Representação do modelo de simulação de DECH (Modelo Alogênico)

Figura 5 - - Representação do Modelo de co-cultivo com Th17

Figura 6 - Estratégia de anáise das populações de linfócitos ativados .............. 37

Figura 7 - A presença de MSCs reduz a ativação de linfócitos T CD3 e CD3:CD4

Figura 8 - Estratégia de análise de proliferação da população de linfócitos...... 38 Figura 9 - A presença de MSCs reduz a proliferação de linfócitos T CD3, CD3:CD4 e CD3:CD8

Figura 10 - A presença de MSC reduz a proliferação de linfócitos de maneira contato-independente.

Figura 11 - Caracterização fenotípica de células dendríticas derivadas de monócitos

Figura 12 - Padronização de reações alogênicas (MLR)

Figura 13 - Estratégia de seleção de população de linfócitos em proliferação.. 44

Figura 14 - Presença de MSC reduz a proliferação de linfócitos CD3 e CD3:CD4 alorreativos. 45

Figura 15 - IDT potencializa efeito antiproliferativo de MSCs em linfócitos ativados com PHA de maneira dose-dependente.

Figura 16 - A adição de triptofano recupera a proliferação de linfócitos T na presença de MSC

Figura 17 - Esquema sugerido da interação entre linfócitos T e MSC .............. 47

Figura 18 - A presença de MSC reduz apoptose de linfócitos.......................... 48

Figura 19 - Estratégia de análise de apoptose ................................................. 49

Figura 20 - Efeito de MSC na apoptose de linfócitos é parcialmente contato-

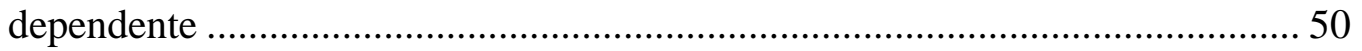

Figura 21 - Efeito anti-apoptótico em linfócitos é dependente de específicas

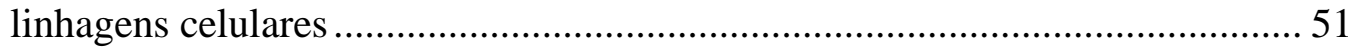

Figura 22 - Efeito anti-apoptótico em linfócitos é dependente de linhagens espécificas

Figura 23 - Presença de MSCs aumenta a expressão de CD127 em linfócitos estimulados com PHA.

Figura 24 - Efeito da IL-7 em linfócitos estimulados com PHA é similar ao efeito da presença de MSCs e a inibição de IL-7 nas culturas com MSC restaura a apoptose.

Figura 25 - Estratégia de seleção de população de MSC positiva para IL-7. .... 54

Figura 26 - Esquema sugerido da interação entre linfócitos T e MSC .............. 54

Figura 27 - Estratégia de avaliação dos linfócitos T vigens após seleção indireta com coluna de seleção .............................................................................. 55

Figura 28 - Imagem de um aglomerado de linfócitos após estímulo com microesferas anti-CD3/CD28 e citocinas......................................................... 56

Figura 29 - Estratégia de análise de população de linfócitos Th17 .................. 56 Figura 30 - Estratégia de gate para verificação da produção de IFN-y e IL-17A por linfócitos $\mathrm{T}$ 
Figura 31 - MSC reduzem a produção de IFN-y e IL-17A de linfócitos T virgens

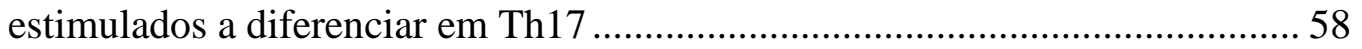

Figura 32 - Estratégia de gate para verificar a produção de citocinas por linfócitos em diferenciação para Th17 na presença de anti-IFN- $\gamma$ 59

Figura 33 - MSC interfere na produção de IL-17A por linfócitos em diferenciação

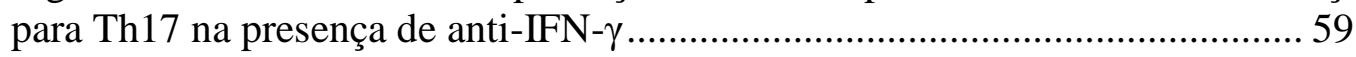

Figura 34 - Estratégia de análise de células T reguladoras ............................... 61 Figura 35 - A presença de MSCs não altera o número de células T reguladoras em culturas para diferenciação para Th17 62

Figura 36 - Esquema sugerido da interação entre linfócitos T e MSC .............. 62 


\section{LISTA DE ABREVIATURAS E SIGLAS}

ANOVA Análise de Variância (do inglês Analysis of variance)

APC Aloficocianina (do inglês Allophycocyanin)

APCs Célula Apresentadora de Antígeno (do inglês Antigen-presenting cell)

ATP Trifosfato de adenosina (do inglês Adenosine triphosphate)

BAD Antagonista de Bcl-2 de morte celular (do ingles Bcl-2-associated death promoter)

BAK Assassino 1 antagonista de Bcl-2 (do inglês Bcl-2 homologous antagonist killer)

BAX Proteína X associada ao Bcl-2 (do inglês Bcl-2-associated X protein)

Bcl-2 Linfoma 2 de célula B de leukemia linfoide crônica (do inglês $B$ cell CLL/Lynphoma 2)

Bcl-XL Gene relacionado com Bcl-2, isoforma longa (do inglês Bcl-2-related gene, long isoform)

BCR Receptor de célula B (do inglês B cell receptor)

BFA Brefeldina A (do inglês Brefeldin A)

BID Agonista de morte que interage com domínio BH3 (do ingles BH3 interacting-domain death agonist)

BIM Mediador de morte cellular interage com linfoma de célula B (do inglês B-cell lymphoma 2 interacting mediator of cell death)

Caspases Cisteíno-proteases de ácido aspártico (do inglês Cysteine-aspartic acid proteases)

CCR Receptor de quimiocina (do inglês chemokine receptor)

CD Aglomerado de diferenciação (do linglês Cluster of differentiation)

CTLA-4 Antígeno 4 Associado com linfócito T citotóxico (do inglês Cytotoxic $T$ Lymphocyte Antigen 4)

CY Ciclofosfamida (do inglês Cyclophosphamide)

DC Célula dendrítica (do inglês Dendritic cells)

DECH Doença do enxerto contra hospedeiro

DISC Complexo indutor de sinalização de apoptose (do inglês Death-inducing signaling complex)

DMEM Meio de cultura Dulbeco modificado (do inglês Dulbecco's Modified Eagle's Medium) 
DMSO Dimetilsulfóxido (do inglês Dimethyl sufoxide)

DNA Ácido desoxirribonucleico (do linglês deoxyribonucleic acid)

ERK1/2 Proteína quinase regulada por sinal extracelular (do inglês Extracellular signal-regulated protein kinases 1 and 2)

FADD Domínio de morte associado ao FAS (do inglês FAS-Associated deaht domain)

FASL Ligante de FAS (do inglês FAS-ligand)

FBS Soro Bovino Fetal (do inglês Fetal bovine serum)

FITC Isotiocianato de fluoresceína (do inglês Fluorescein isothiocyanate)

FoxP3 Cabeça em garfo/hélice P3 (do inglês forkhead box P3)

FSC Dispersão para frente (do inglês Forward Scatter)

GM-CSF Fator estimulador de colônias de granulócitos e macrófagos (do inglês Granulocyte-macrophage colony-stimulating fator)

GvL Enxerto contra leucemia (do inglês Graft versus leucemia)

GvT Enxerto contra tumor (do inglês Graft versus tumor)

HLA Antígeno Leucocitário Humano

HSCT Transplante de célula tronco hematopoiética (do inglês hematopoietic stem cell transplantation)

IDO Indoleamina 2,3 dioxigenase (do inglês Indoleamine 2,3-dioxygenase)

IDT Indometacina

IFN- $\gamma \quad$ Interferon $\gamma$

IL Interleucina (do inglês interleukin)

IRF Fator regulado por interferon (do inglês Interferon regulatory factor)

LAT Ligante para ativação de célula T (do inglês Linker for Activated T cells)

Lck Proteína tirosina quinase específica de linfócito (do inglês Lymphocytespecific protein tyrosine kinase)

LMN Linfomononuclear

LPS Lipopolissacarídeo (do inglês Lipopolysaccharide)

MHC Complexo principal de histocompatibilidade (do inglês Major histocompatibility complex)

MLR Reação mista de linfócitos (do inglês mixed lymphocyte reaction)

MO Medula Óssea

MSC Célula-tronco mesenquimal (do inglês Mesenchymal stem cell) 
NF- $k$ B Fator nuclear kappa B (do inglês nuclear factor kappa-light-chainenhancer of activated $B$ cells)

NIH Instituto Nacional de Saúde (do inglês National Institutes of Health)

NK Célula matadora natural (do inglês natural killers )

NLR Receptor semelhante a NOD (do inglês Nod like receptor)

P Passagem celular

PAMP Padrões moleculares associados a patógenos (do inglês Pathogenassociated molecular patterns)

PBMC Célula Mononuclear de sangue periférico (do inglês Peripheral blood mononuclear cell)

PBS Tampão fosfato-salino sem cálcio e sem magnésio (do inglês Phosphate buffered saline)

PE Ficoeritrina (do inglês Phycoerythrin)

PercP Proteína Clorofila Peridinina (do inglês Peridinin chlorophyll)

PGE2 Prostaglandina E2 (do inglês Prostaglandin E2)

PHA Fitohemaglutinina (do inglês phytohemaglutinin)

PMA Forbol 12-miristato 13-acetato (do inglês Phorbol 12-myristate 13acetate)

PRR Receptor de reconhecimento padrão (do inglês Pattern recognition receptor)

RADS Unidade de dose de radiação

ROR Receptor órfão retinóide (do inglês Retinoid-related orphan receptor)

SLP-76 Proteína leucocitária contendo domínio 2 homólogo ao Src (do inglês Src homology 2 domain-containing leukocyte protein of $76 \mathrm{kDa}$ )

SSC Dispersão para o lado (do inglês Sideward Scatter)

TCR Receptor de célula $\mathrm{T}$ (do inglês $T$ cell receptor)

TGF Fator de crescimento de célula T (do inglês $T$ cell grown fator)

Th Célula T auxiliar (do inglês Thelper cells)

TLR Receptor semelhante a Toll (do inglês Toll like receptor)

TNF Fator de necrose tumoral (do inglês Tumor necrosis factor)

Treg Célula T reguladora (do inglês Regulatory $T$ cells)

ZAP-70 Proteína quinase associada a cadeia zeta 70 (do inglês Zeta-chainassociated protein kinase 70) 


\section{LISTA DE SÍMBOLOS}

$\begin{array}{ll}\boldsymbol{\mu g} & \text { Micrograma } \\ \boldsymbol{\mu L} & \text { Microlitro } \\ { }^{\mathbf{0}} \mathbf{C} & \text { Grau Célsius } \\ \mathbf{c m} & \text { Centímetro } \\ \mathbf{g} & \text { Força Centrífuga Relativa } \\ \mathbf{m L} & \text { Mililitro } \\ \mathbf{n g} & \text { Nanograma }\end{array}$




\section{RESUMO}

Normanton M. Estudo da interação das células-tronco mesenquimais e linfócitos no modelo da doença do enxerto contra hospedeiro [Dissertação]. São Paulo. Faculdade de Medicina, Universidade de São Paulo; 2014.

Uma das principais complicações inerentes ao transplante de células-tronco hematopoiéticas é a doença do enxerto contra hospedeiro (DECH), que se trata da resposta imunológica contra os tecidos do receptor pelas células $\mathrm{T}$ do doador contidas no transplante. Este quadro é responsável por $15-30 \%$ das mortes que ocorrem após o transplante de células-tronco hematopoiéticas alogênicas. Apesar dos recentes avanços para reduzir a incidência de $\mathrm{DECH}$ através de alternância de regimes profiláticos reduzindo a intensidade do condicionamento, são poucos os tratamentos efetivos. Recentemente, o potencial imunomodulador das células-tronco mesenquimais tornou-se o foco de vários estudos. Alguns autores descreveram a atuação destas células na redução da resposta imunológica através da inibição da proliferação de células $T$, representando um novo potencial terapêutico para DECH.

Mediante esse conhecimento, investigamos o papel das células-tronco mesenquimais na proliferação, apoptose e na produção de citocinas por linfócitos T. Nossos resultados mostraram que a presença de células-tronco mesenquimais nas culturas regulam negativamente a proliferação de linfócitos $\mathrm{T}$ estimulados de forma independente de contato e a apoptose de forma parcialmente dependente de contato. Observamos também que linfócitos $\mathrm{T}$ virgens em diferenciação para Th17 na presença de célulastronco mesenquimais apresentam redução na capacidade de produzir duas importantes citocinas efetoras implicadas na $\mathrm{DECH}$, o interferon gama (IFN- $\gamma$ ) e a interleucina $17 \mathrm{~A}$ (IL-17A).

Investigamos se a prostaglandina E2 (PGE2), por depletar triptofano, estava envolvida com a diminuição de proliferação de linfócitos $\mathrm{T}$ quando em cultivo com células-tronco mesenquimais. Utilizamos nas culturas a indometacina (IDT), um anti-inflamatório bloqueador de cicloxigenase (COX 1 e 2) e portanto da via da PGE2. Entretanto, observamos que o bloqueio da via da PGE2 inibia ainda mais a proliferação de linfócitos $\mathrm{T}$ e isto ocorria de acordo com a dose de IDT. Com o resultado deste experimento concluímos que, se a proliferação de linfócitos é inibida pela depleção de triptofano do meio, ela não ocorre via PGE2. Entretanto ainda não conseguimos esclarecer se esta via é ativada por outras moléculas, ou se é esta a via realmente responsável pela inibição da proliferação de linfócitos.

No que concerne a via de inibição de apoptose, mostramos que a cadeia alpha do receptor de IL-7 (CD127) está aumentada na superfície de linfócitos T quando em presença de células-tronco mesenquimais. Verificamos que o bloqueio de IL-7 nas culturas aumenta a apoptose em linfócitos, bem como sua adição causa diminuição de apoptose. Identificamos a produção intracelular de IL-7 nas células-tronco mesenquimais, relacionando estas células e IL-7 com a inibição de apoptose em linfócitos T nestas condições.

Este trabalho gerou dados que permitiram a compreensão de alguns possíveis mecanismos pelos quais as MSCs podem atuar sobre linfócitos T ativados e/ou alorreativos; mecanismos estes que podem ser utilizados como base para futuras investigações na elucidação e prevenção da $\mathrm{DECH}$. 
Descritores: Doença enxerto-hospedeiro; transplante de medula óssea; células-tronco adultas; linfócitos T; interleucina-7; apoptose e proliferação de células 


\begin{abstract}
Normanton M. Study of mesenchymal stem cells and lymphocytes interaction in graft versus host disease model [Dissertation]. São Paulo. "Faculdade de Medicina, Universidade de São Paulo", 2014.
\end{abstract}

A major complication after hematopoietic stem cell transplantation is the graft versus host disease (GVHD), which is an immunological response of transplanted donor $\mathrm{T}$ cells against the recipient tissues; this outline is responsible for $15-30 \%$ of deaths that can occur after allogeneic hematopoietic stem cells transplant.

Despite recent advances in reducing GVHD incidence by alternating prophylactic regimens, thus reducing the intensity of conditioning, there are few effective treatments.

Recently, the immune modulatory potential of mesenchymal stem cells has become the focus of several studies. Some authors described the role of these cells in reducing immune response by inhibiting $\mathrm{T}$ cell proliferation, representing a potential new therapy for GVHD.

Through this knowledge, we investigated the mesenchymal stem cells role into $\mathrm{T}$ lymphocytes proliferation, apoptosis and cytokine production. Our results showed that the presence of mesenchymal stem cells into the cultures downregulates the proliferation of stimulated lymphocytes independent of contact and apoptosis of stimulated lymphocytes in partially contact-dependent manner. We also observed during naive $\mathrm{T}$ lymphocytes differentiation into Th17 cells, that the mesenchymal stem cell presence reduces the lymphocyte ability in producing the GVHD major effectors cytokines, interferon gamma (IFN- $\gamma$ ) and interleukin-17A (IL-17A).

We investigated whether prostaglandin E2 (PGE2) was involved in the reduction of $\mathrm{T}$ lymphocytes proliferation, when cultured with mesenchymal stem cells, by tryptophan depletion. Indomethacin (IDT), an anti-inflammatory drug blocker of cyclooxygenase (COX 1 and 2) and therefore PGE2 pathway, was used. However, we observed that, according to IDT dose, blocking this pathway further inhibited lymphocyte proliferation. With this result we conclude that if lymphocyte proliferation is inhibited by tryptophan depletion, it does not occur via PGE2. However, we still cannot say whether this pathway is activated by other molecules, or if this pathway is actually responsible for $\mathrm{T}$ lymphocytes proliferation inhibition.

Regarding the apoptosis inhibition in T lymphocytes, we show that the IL-7 receptor alpha chain (CD127) is increased on the surface of T lymphocytes when in the presence of mesenchymal stem cells. We found that IL-7 blockage in the cultures increases apoptosis in T lymphocytes, as well as their addition causes apoptosis decrease. We also identified the intracellular production of IL-7 on mesenchymal stem cells, linking these cells and IL-7 directly with apoptosis inhibition in T lymphocytes under these conditions

This work has generated data that allowed the understanding of some possible mechanisms by which MSCs can act on activated and/or alloreactive T lymphocytes; mechanisms that can be used as a basis for future research in the elucidation and prevention of GVHD. 
Descriptors: Graft vs host desease; bone marrow transplantation; adult stem cells; Tlymphocytes; interleukin-7; apoptosis and cell proliferation. 
FICHA CATALOGRÁFICA

\section{SUMÁRIO}

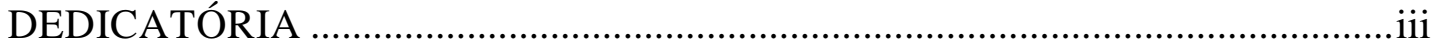

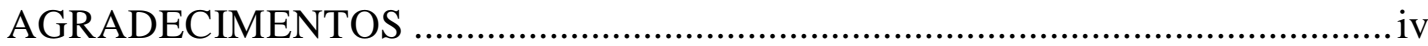

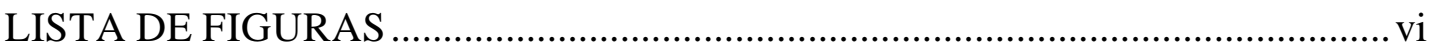

LISTA DE ABREVIATURAS E SIGLAS …................................................... viii

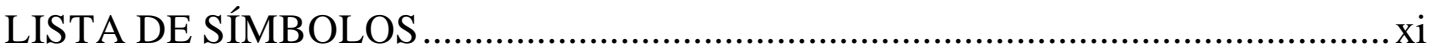

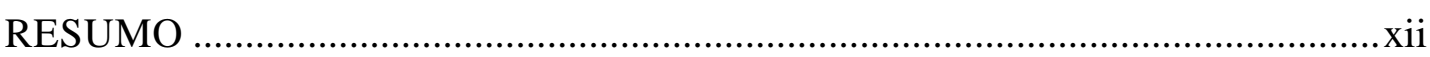

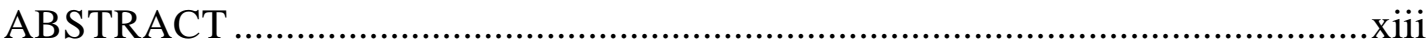

SUMMARY

1 INTRODUÇÃ

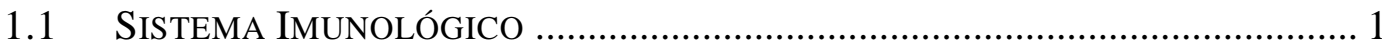

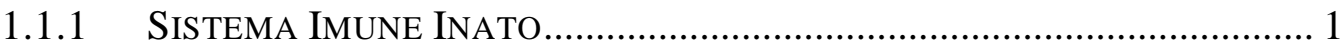

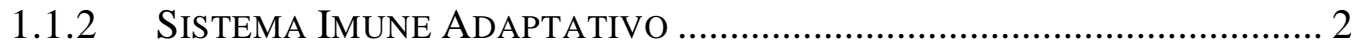

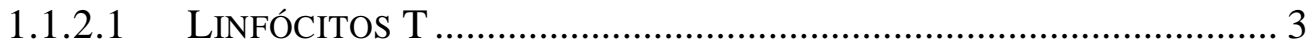

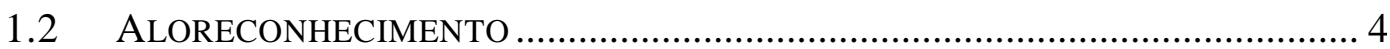

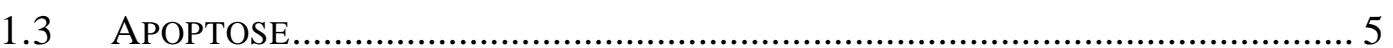

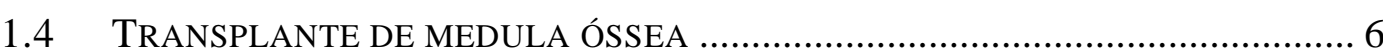

1.5 DOENÇA DO ENXERTO CONTRA HOSPEDEIRO (DECH) ............................. 9

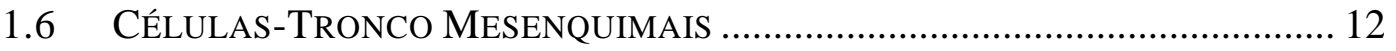

1.6.1 REGULAÇÃO IMUNE POR CÉLULAS-TRONCO MESENQUIMAIS .............. 12

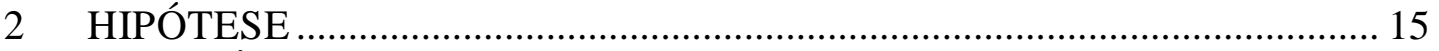

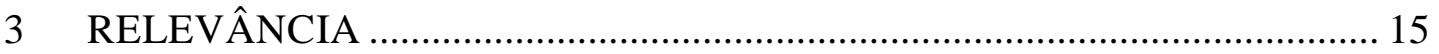

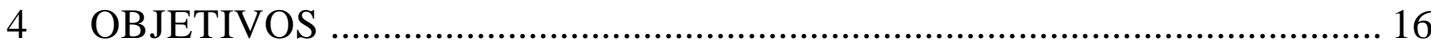

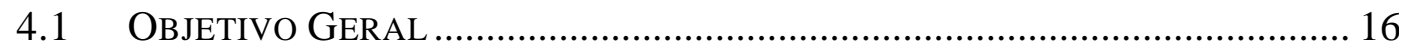

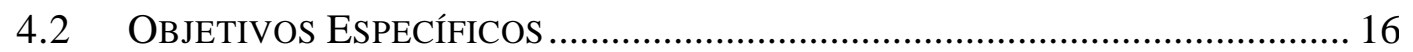

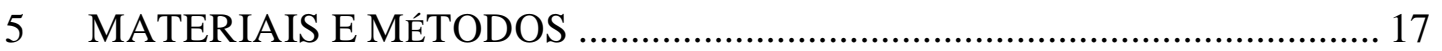

5.1 OBTENÇÃO DE CÉLULAS-TRONCO MESENQUIMAIS ...................................... 17

5.2 PlaQUEAMENTO DE CÉLULAS-TRONCO MESENQUIMAIS ........................... 18

5.3 CARACTERIZAÇÃO IMUNOFENOTÍPICA DE MSCS POR CITOMETRIA DE

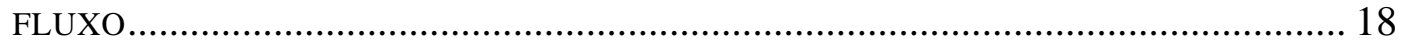

5.4 DIFERENCIAÇÃO DAS CÉLULAS-TRONCO MESENQUIMAIS ......................... 19

5.4.1 PROTOCOLO DE DIFERENCIAÇÃO ADIPOGÊNICA ................................. 19

5.4.2 PROTOCOLO DE DIFERENCIAÇÃO OSTEOGÊNICA................................ 19

5.4.3 PROTOCOLO DE DIFERENCIAÇÃO CONDROGÊNICA ….......................... 20

5.5 MÉTODOS DE COLORAÇÃO IMUNO-HISTOQUÍMICA .................................... 20

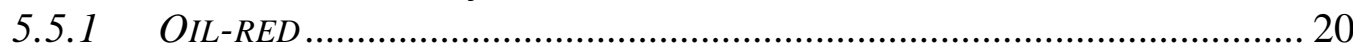

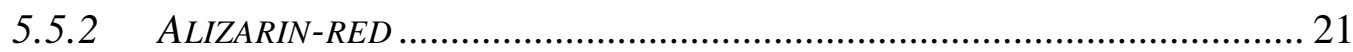

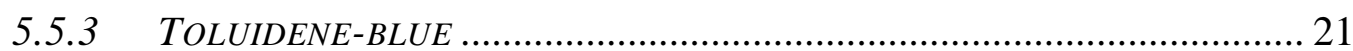

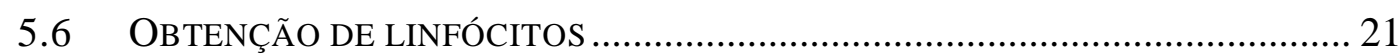

5.7 CARACTERIZAÇÃO IMUNOFENOTÍPICA DE LINFÓCITOS T .......................... 22

5.8 PROTOCOLO DE DIFERENCIAÇÃO EM LINFÓCITOS TH17 ........................... 22

5.9 CARACTERIZAÇÃO IMUNOFENOTÍPICA DOS LINFÓCITOS TH17 E TREG POR

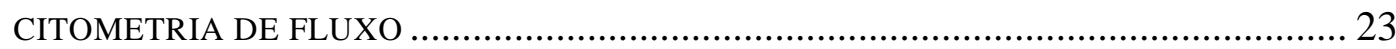

5.10 ENSAIOS DE PROLIFERAÇÃO E MORTE CELULAR ……........................... 25

5.11 OBTENÇÃO DE MONÓCITOS CD14 _.................................................... 25

5.12 PROTOCOLO DE DIFERENCIAÇÃO DE CÉLULAS DENDRÍTICAS ................ 27

5.13 CARACTERIZAÇÃO IMUNOFENOTÍPICA DE MONÓCITOS, CÉLULAS

DENDRÍTICAS IMATURAS E CÉLULAS DENDRÍTICAS MADURAS POR CITOMETRIA

DE FLUXO 
5.14 PROTOCOLO DE CONGELAMENTO E DESCONGELAMENTO DE CÉLULAS . 28

5.15 MODELOS UTILIZADOS IN VITRO ......................................................... 29

5.15.1 CONTROLE POSITIVO - ESTÍMULO COM PHA ................................. 29

5.15.2 SIMULAÇÃO DECH (MODELO ALOGÊNICO) …................................. 30

5.15.3 CO-CULTIVO DE CÉLULAS TH17 ................................................... 31

5.16 CULTURA CELULAR COM INDOMETACINA …........................................... 32

5.17 CULTURA CELULAR COM INTERLEUCINA 7 RECOMBINANTE HUMANA E

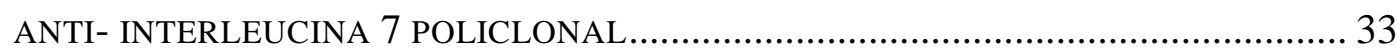

5.18 ENSAIO DE PRODUÇÃO DE IL-7 POR MSC ......................................... 34

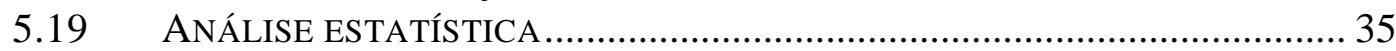

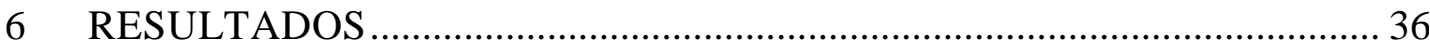

6.1 PARTE I - ISOLAMENTO E CARACTERIZAÇÃO DE CÉLULAS MESENQUIMAIS

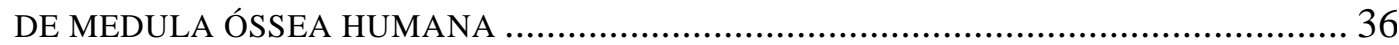

6.2 PARTE II - EFEITO DAS CÉLULAS-TRONCO MESENQUIMAIS NA ATIVAÇÃO E

PROLIFERAÇÃO DE LINFÓCITOS. ..................................................................... 36

6.2.1 A presença de MSC reduz a ativação de linfócitos estimulados com

PHA 36

6.2.2 A presença de MSC reduz a proliferação de linfócitos ativados com

PHA 38

6.2.3 MSC reduzem a proliferação de linfócitos de forma independente de contato 40

6.2.4 Diferenciação de células dendritícas alogenicas para realização de reação mista de linfócitos

6.2.5 Titulação de linfócitos:DCs para realização de MLR ....................... 42

6.2.6 MSC reduzem a proliferação de linfócitos estimulados com células dendríticas alogênicas

6.2.7 Indometacina potencializa o efeito antiproliferativo de MSC em linfócitos

6.2.8 A adição de triptofano recupera a proliferação de linfócitos na presença de MSC 46

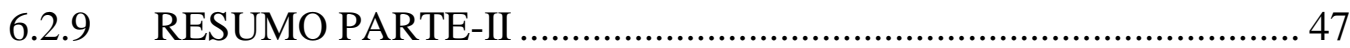

6.3 PARTE III - EFEITO DE MSCS NA APOPTOSE DE LINFÓCITOS .................. 48

6.3.1 A presença de MSC reduz apoptose de linfócitos estimulados com

PHA 48

6.3.2 O efeito anti-apoptótico das MSC em linfócitos é parcialmente-

dependente de contato

6.3.3 Células de origem mesodérmica reduzem a apoptose de linfócitos .... 50

6.3.4 MECANISMO DE AÇÃO DAS MSCS EM LINFÓCITOS ............................ 52

6.3.5 Bloqueio de IL-7 nas co-culturas aumenta a apoptose de linfócitos ... 52

6.3.6 MSC produzem a citocina IL-7 .................................................. 53

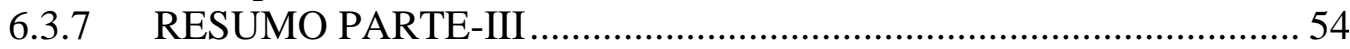

6.4 PARTE IV - EFEITO DAS MSCS EM LINFÓCITOS TH17 …........................... 55

6.4.1 Caracterização da população de linfócitos Th17 ................................ 55

6.4.2 MSC interferem na produção de IFN- $\gamma$ por linfócitos T...................... 56

6.4.3 MSC reduzem a produção de IL-17A por linfócitos ........................... 58

6.4.4 MSC reduzem a produção de IL-17A, mas não alteram porcentagem número de células T reguladoras nas culturas .................................................... 60

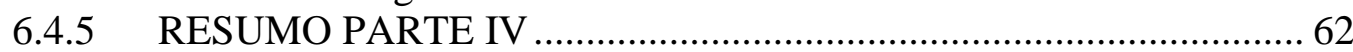

7 DISCUSS ÃO

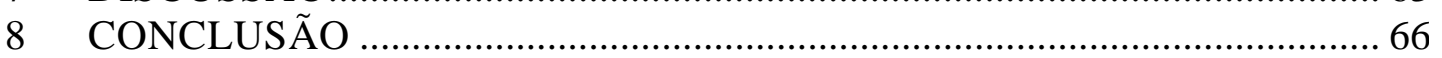




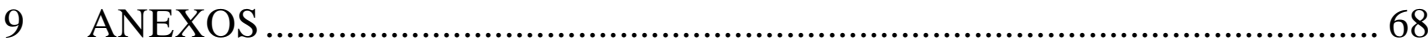

9.1 PARECER - CERTIFICADO DE APRESENTAÇÃO PARA APRECIAÇÃO ÉTICA . 68

9.2 TERMO DE CIÊNCIA DO COMITÊ DE ÉTICA EM PESQUISA …........................ 71

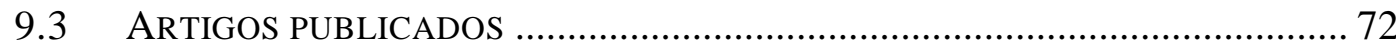

9.3.1 "ISOLAMENTO E CARACTERIZAÇÃO DE CÉLULAS-TRONCO MESENQUIMAIS DE FILTROS REUTILIZÁVEIS E DESCARTÁVEIS DE MEDULA ÓSSEA" 72

9.3.2 DADOS RECENTES EM IL-17 E TH17 E IMPLICAÇÕES NA DOENÇA DO ENXERTO CONTRA HOSPEDEIRO

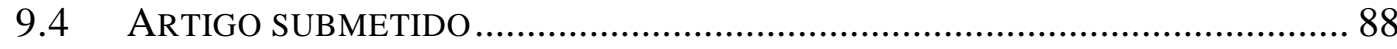

10 REFERÊNCIAS BIBLIOGRÁFICAS 110 


\section{INTRODUÇÃ̃o}

\subsection{Sistema IMUNOLÓgico}

O sistema imunológico é classificado em sistema imune inato e adaptativo, que são distintos principalmente em seus níveis de especificidade de reconhecimento de antígenos. Os receptores do sistema imune adaptativo mediam respostas altamente específicas, em contraste com os receptores mais promíscuos e menos específicos do sistema imune inato (1).

\subsubsection{Sistema IMUNE INATO}

A imunidade inata é uma resposta rápida e estereotipada a um grande número, mas limitado, de estímulos. É representada por barreiras físicas, químicas, biológicas, células especializadas e moléculas solúveis presentes em todos os indivíduos. Esta resposta ocorre independente do contato prévio com imunógenos ou agentes agressores, e não é alterada qualitativa ou quantitativamente após o primeiro contato com o antígeno (2).

As principais células efetoras da imunidade inata são: macrófagos, neutrófilos, células dendríticas (DCs) e células Natural Killer (NK). A fagocitose, liberação de mediadores inflamatórios, ativação de proteínas do sistema complemento, bem como a síntese de proteínas de fase aguda, citocinas e quimiocinas, são os principais mecanismos efetores na imunidade inata. Esses mecanismos são ativados por estímulos específicos, reconhecidos por seus receptores (3).

Os receptores presentes nas células do sistema imune inato são principalmente os receptores de reconhecimento padrão (PRR) expressos na superfície celular ou intracelular, como os receptores semelhantes à Toll (TLR) e receptores semelhante à NOD (NLR) $(4,5)$. Os PRR não reconhecem apenas padrões moleculares associados a patógenos (PAMPs), que incluem ácido nucléico, bacteriano e viral, lipopolissacarídeos (LPS), proteoglicanos e carboidratos, mas 
também reconhecem padrões moleculares associados a danos ao hospedeiro, como a adenosina tri-fosfato (ATP) e ácido desoxirribonucleico (DNA) próprio. O reconhecimento desses padrões resulta na sinalização intracelular e na ativação de fatores de transcrição, como o NF- $k \mathrm{~B}$ e fatores regulados por interferon (IRFs) (6). A ativação de fatores de transcrição leva à liberação de citocinas e quimiocinas conduzindo a um ambiente inflamatório, com recrutamento e ativação celular, incluindo a expressão de moléculas co-estimulatórias pelas células apresentadoras de antígenos (APC), cujo papel é crucial para ativação da resposta imune adaptativa (7).

\subsubsection{Sistema ImUne AdAPTATIVo}

As DCs são consideradas uma ponte entre a imunidade inata e adaptativa. As DCs são atraídas e ativadas por sinais liberados por células da imunidade inata e viabilizam a progressão da resposta imune adaptativa. Essas células residem em tecidos periféricos, como pele, fígado e intestino, onde capturam antígenos, se tornam ativadas e migram para órgãos linfóides secundários, como por exemplo, os linfonodos regionais, onde processam o antígeno. As DCs maduras expressam em sua membrana celular moléculas co-estimulatórias, B7-1 e B7-2, também conhecidos como CD80 e CD86, tornando-se capazes de co-estimular (8) e apresentar antígenos protéicos associados a moléculas de histocompatibilidade principal (MHC) aos linfócitos. DCs imaturas são altamente eficientes na captura de antígenos, enquanto que as maduras são muito eficientes na apresentação (9).

Essas células orquestram a migração de outros tipos celulares dentro dos linfonodos via a secreção de quimiocinas. As DCs também regulam a diferenciação, maturação e função de linfócitos de maneira contato-dependente e através da secreção de fatores solúveis, sendo, portanto, fundamentais para o início e coordenação da resposta imunológica adaptativa (9).

A resposta imune adaptativa depende da ativação de células especializadas e de moléculas solúveis produzidas por linfócitos. Suas principais características são: alta especificidade e diversidade de reconhecimento, memória, capacidade de finalizar a respota e tolerância. 
As principais células efetoras do sistema imune adaptativo são os linfócitos T e B, cuja ativação ocorre após a ativação do receptor de célula T (TCR) pela ligação com MHC presentes nas APC, ou pela ativação dos receptores de células B (BCR), respectivamente (10).

Juntos, os TCRs e BCRs possuem um vasto repertório, possibilitando o sistema imune adaptativo detectar qualquer antígeno. A ampla diversidade desses receptores é gerada por recombinação somática de regiões específicas do DNA, e cada receptor possui uma especificidade particular e é expresso em um clone de linfócitos.

As células precursoras dos linfócitos $\mathrm{T}$ deixam a medula óssea (MO) e migram para o timo, onde ocorre todo o processo de diferenciação e seleção. Apenas os linfócitos T diferenciados deixam o timo e caem na circulação. Os precursores dos linfócitos $\mathrm{B}$, permanecem na $\mathrm{MO}$ e, ao final de sua diferenciação, entram para a circulação e migram para órgãos linfóides secundários, onde exercem algumas de suas funções (11).

\subsubsection{LINFÓCITOS T}

No timo, os linfócitos $\mathrm{T}$ passam por vários processos para seu desenvolvimento que resulta do rearranjo gênico e expressão das cadeias $\alpha / \beta$ ou $\gamma / \delta$ do TCR, do co-receptor CD3 (12-14) e da expressão das moléculas CD4 ou CD8 na membrana celular, descritas como células $\mathrm{T}$ auxiliares (Th) ou citotóxicas, respectivamente (15). Após a expressão dessas moléculas, os linfócitos T seguem para o processo de seleção positiva $(16,17)$, onde peptídeos próprios são apresentados por células epiteliais do timo via MHC classe I ou classe II para linfócitos CD4 ou CD8, respectivamente, os linfócitos que não reconhecem os peptídeos próprios, mas são capazes de reconhecer as moléculas de MHC próprias, recebem sinais para sobrevivência e maturação (18-21). A seleção tímica positiva e negativa tem como objetivo a deleção de células com afinidade muito baixa ou muito elevada ao MHC e de células autorreativas (22). 


\subsection{Aloreconhecimento}

A aloreatividade se refere à capacidade da célula $\mathrm{T}$ em reconhecer complexos de peptídeos acoplados a MHC alogênico (23). Apenas de 1-10\% dos linfócitos são capazes de reconhecer MHC alogênico. Diferentes teorias têm sido propostas para tentar explicar essa alta frequência, mas este ponto ainda não foi elucidado (24).

O papel das DCs imunogênicas foi notado inicialmente no cenário de transplante, em um modelo de cultura celular para determinar rejeição de enxerto chamado de reação mista de linfócitos (MLR) (25). O MLR permite a detecção de incompatibilidades entre moléculas de MHC de doadores e receptores de transplante de órgãos. Essa incompatibilidade é frequente devido ao polimorfismo dos genes do MHC que leva a grande variabilidade fenotípica. Devido a esta grande variabilidade os linfócitos $\mathrm{T}$ reconhem as moléculas de $\mathrm{MHC}$ não próprias e reagem contra o tecido alogenico levando a rejeição (25).

Em 1986, Mosmann e colaboradores publicaram um trabalho sobre o comportamento clonal das células T CD4 (14). Frente a um amplo painel de antígenos específicos e clones de células $\mathrm{T}$ autorreativas, eles foram capazes de dividir essas células em dois grupos distintos: células auxiliares tipo 1 (Th1), cujos clones gerados na presença de interleucina (IL) 2, IL-3 e interferon gamma (IFN- $\gamma$ ) e células auxiliares tipo 2 (Th2), cujos clones são gerados na presença de IL-3, fator de crescimento de célula T (TGF) 2 e fator de crescimento de mastócito (2). Um trabalho subsequente de Cherwinski mostrou que os clones de Th1 eram gerados pela presença de IL-2, fator de estimulante de colônia de macrófago e granulócito (GMCSF) e IFN- $\gamma$, e os clones de Th2 gerados na presença de IL-4 e IL-5 (15).

Entretanto, trabalhos mais recentes mostram que a via de diferenciação de células auxiliares tipo 17 (Th17) e células T reguladoras (Treg) é separada da via de diferenciação Th1 ou Th2 (26). A via para a diferenciação em Th17 necessita de fator de transformação do crescimento (TGF- $\beta 1$ ) e IL-6, e é aumentado por IL-1 $\beta$ e fator de necrose tumoral (TNF- $\alpha$ ) (27). Em adição, os fatores de crescimento do receptor órfão retinóide (ROR) ROR $\gamma \mathrm{t}$ e $\mathrm{ROR} \alpha$ se mostraram críticos para $\mathrm{o}$ desenvolvimento de Th17. 
As citocinas de Th1 e Th2 inibem a diferenciação de outras células em Th17 como, por exemplo, a IL-2, IFN- $\gamma$ e IL-4. Em camundongos, as células Th17 são maioria nos pulmões, trato gastrointestinal e são consideradas importantes para a manutenção da defesa da mucosa do hospedeiro (28).

As células Th17 também mediam patologias em diversas condições autoimunes, o que acreditava ser somente por efeito de resposta Th1. Níveis elevados de IL-17 têm sido observados em artrite reumatóide, esclerose múltipla e doenças inflamatórias (29). Essas células estão envolvidas na remoção de patógenos extracelulares, particularmente em superfícies mucosas, onde a IL-17 induz o recrutamento e diferenciação de neutrófilos e IL-22 é necessária para a produção de defensinas antimicrobianas (30).

É razoável acreditar que as células Th17, juntamente com Th1, atuem na fisiopatologia das doenças autoimunes (31).

As células T CD4 também podem adquirir um perfil regulador, pois o fator de transcrição FoxP3 foi identificado como um regulador essencial e que controla a expressão de múltiplos genes que mediam suas funções supressoras $(32,33)$.

\subsection{APOPTOSE}

A apoptose é a morte celular programada e está envolvida em grande parte das respostas que ocorrem in vivo e in vitro. Existem duas vias de morte por apoptose, a via extrínseca ou via receptor de morte e via intrínseca ou mitocondrial.

A via extrínseca é iniciada pela ligação de receptores de morte situados na membrana celular, como o CD95 (também conhecido como FAS) que é uma proteína transmembrana responsável por transmitir sinais de morte para o interior da célula, esse receptor, ativado quando se liga ao seu ligante CD95L (FASL), leva a ativação da proteína adaptadora do domínio de morte associada ao FAS (FADD), formando o complexo de sinalização que induz morte (DISC) e ativação de cisteíno-proteases (caspases) (34).

A via intrínseca ou mitocondrial é induzida por estresse extracelular e envolve a ativação de mediadores pró-apoptóticos da família do linfoma de célula B 2 (Bcl-2), como o mediador de morte celular que interage com Bcl-2 (BIM), que leva a 
permeabilização da membrana mitocondrial e permite a ativação do apoptossomo que contém proteases apoptóticas (34).

Os membros da família do Bcl-2 podem ser divididos em três grupos: os membros pró-sobrevivência como o Bcl-2, Bcl-XL e Bcl-W, entre outros; os efetores, proteína $\mathrm{X}$ associada ao Bcl-2 (BAX) e do antagonista/morte de Bcl-2 (BAK), assim induzem a permeabilização da membrana mitocondrial e o terceiro grupo, que incluem proteínas de domínio homólogo ao Bcl-2, antagonistas de Bcl-2 (BIM e BAD) e que interagem com domínio de morte (BID) (35).

O processo de apoptose (via extrínseca e intrínseca) culmina na ativação de caspases, que são uma família de cisteínas proteases aspartato específicas, que clivam proteínas celulares essenciais (35), fragmentam o DNA e levam a formação de corpos apoptóticos que são, posteriormente, reconhecidos, por expressarem em sua membrana celular folfatidil-serinas, por fagócitos (36).

Citocinas como a IL-7 e IL-3 são importantes mediadoras do crescimento e sobrevivência dos linfócitos T e B. A IL-7, em particular, é necessária para a homeostase periférica das células $\mathrm{T}$ CD4 e T CD8 por mecanismos não completamente conhecidos (37-40). Essas citocinas são conhecidas por previnirem as células da apoptose através da indução de proteínas anti-apoptóticas como Bcl-2 ou Bcl-XL e por inibirem proteínas pró- apoptóticas, como BAX, BAD ou BIM (39, 41-43).

\subsection{Transplante de Medula ósSEa}

O histórico do transplante de medula óssea tem vários aspectos peculiares, desde os estudos iniciais até o seu reconhecimento em 1990 com o Prêmio Nobel de medicina ao Dr. E. Donnall Thomas.

No início do século 20, o trabalho de Alexis Carrel e outros, estabeleceram que aloenxertos de pele ou órgãos poderiam funcionar pelo período de uma ou duas semanas e depois seriam perdidos, ou seja, rejeitados (44).

Em 1940, Medawar e colaboradores, estabeleceram as bases imunológicas da rejeição ao enxerto alogeneico. Entretanto, a sugestão de que aloenxertos não seriam sempre rejeitados veio de Owen, que demonstrou que gemelares dizigóticos bovinos 
tinham uma mistura de células sanguíneas de cada parte. Billigham, Brent e Medwar mostraram que tolerância doador-específica em camundongos poderia ser induzida pela injeção de células do doador em recém-nascidos (44).

O início da imunologia dos transplantes foi descrita em detalhes por Woodruff (1960), que descreveu a tolerância a enxertos de pele induzida pelo transplante de MO. Esta observação foi feita após a publicação de Ford e colaboradores (1956) que demonstraram que camundongos irradiados que receberam infusão de MO apresentaram características citogenéticas da medula do doador (44).

Estudos realizados no sistema murino estabeleceram muitos dos fatores responsáveis pelo sucesso ou falha do transplante de MO. Os estudos iniciais foram detalhados no livro de van Bekkum \& De Vries (1967) e as observações mais importantes foram:

1. A primeira questão a ser respondida foi como as células da medula transplantada chegariam até a MO do receptor. No início as células foram injetadas de maneira intra-arterial, intraperitoneal e diretamente nas cavidades medulares, entretanto foi Van Bekkum e colaboradores que demonstraram que as células injetadas de forma intravenosa eram efetivas na repopulação medular; (45)

2. Células de MO alogênicas enxertadas em camundongos não isogênicos podiam desenvolver um ataque imunológico contra o receptor resultando em uma síndrome conhecida como "doença secundária". Esta doença é o resultado de uma reação imune dos linfócitos enxertados contra os tecidos do hospedeiro, hoje conhecida como a doença do enxerto contra o hospedeiro (DECH); (46)

3. Nos transplantes alogênicos a severidade da reação imune das células do doador contra o receptor é controlada por fatores genéticos; (47)

4. A histocompatibilidade era governada por um sistema maior e vários sistemas menores; (48)

5. Metotrexato podia prevenir e melhorar a DECH; $(49,50)$

6. Ciclofosfamida (CY) sozinha podia oferecer imunossupressão suficiente para enxertos alogênicos e (51) 
7. A importância do timo, células T, B e outros subtipos linfóides começam a ser definidos na biologia dos transplantes $(52,53)$.

As experiências iniciais com transplante de células tronco hematopoéticas (HSCT) se deram com as imunodeficiências. No final dos anos 60, as transfusões de plaquetas, antibióticos de amplo espectro e agentes anti-câncer mais efetivos já tinham sido desenvolvidos. $\mathrm{O}$ conhecimento crescente do sistema de histocompatibilidade levou a novas tentativas de transplante alogênico em pacientes humanos. Gatti e colaboradores (1968) reportaram o primeiro sucesso de enxerto alogênico em um paciente com deficiência imunológica combinada grave, ele utilizou como doador o irmão, que considerado com antígeno leucocitário humano (HLA) idêntico, entretanto uma tipagem subseqüente mostrou que o doador e receptor diferiam em alguns dos antígenos HLA (54). Outros dois sucessos similares foram reportados praticamente ao mesmo tempo $(55,56)$, os pacientes não necessitaram de terapia imunossupressora uma vez que eles eram imunoincompetentes devido à doença. Todos os três estavam vivos e bem 25 anos após o transplante (57).

Desde estes primeiros três casos de HSCT alogênicos de sucesso, mais de 800.000 pacientes receberam transplante alogênico ou autólogo (58). Esse tratamento tem sido usado mundialmente por mais de 50.000 pacientes a cada ano. Desde o início de 1970, a mortalidade durante os primeiros 100 dias após o HSCT tem diminuído devido a mudanças nos critérios de seleção de pacientes, refinamento dos regimes de condicionamento pré-transplante e melhoras na prevenção de doenças. As taxas de sobrevivência acima de um ano já ultrapassam 60\% para pacientes com HLA idêntico aos doadores (58). Com a diminuição da mortalidade precoce e maior uso do HSCT, o número de pacientes com boa sobrevida agora ultrapassam 150.000 e continua a crescer.

A primeira utilização intravenosa de MO foi realizada por Osgood em 1939. Os problemas iniciais foram grandes no início do transplante. No campo do transplante autólogo os desafios eram com a criopreservação da medula e no transplante alogênico, os problemas imunológicos com a rejeição (59). Em 1961, Friedman padronizou o MLR e somente com a caracterização do HLA o transplante alogênico ganhou mais impulso (60). 
George Mathé foi pioneiro no desenvolvimento do transplante de medula clínico e também o primeiro a descrever a doença do enxerto contra hospedeiro (DECH) em humanos. McFarland, em 1961, foi o primeiro a identificar que o condicionamento pré-transplante de MO era importante para a recuperação na nova medula e nos casos de leucemia, para a erradicação do tumor (61).

No Brasil, os estudos iniciais foram realizados pelo Dr. Ricardo Pasquini e seu grupo do Paraná, e em 1979 realizou o primeiro transplante no Brasil junto com o Dr. Eurípedes Ferreira (62).

\subsection{DOENÇA DO ENXERTO CONTRA HOSPEDEIRO (DECH)}

O número de transplantes alogênicos com células progenitoras hematopoéticas vem crescendo e mais de 50.000 procedimentos são realizados anualmente (63). O HSCT alogeneico é uma opção para a cura/melhora de inúmeras doenças hematológicas malignas, entretanto, o desenvolvimento da DECH limita o sucesso do HSCT alogênico e é fatal em aproximadamente $15 \%$ dos casos (64).

Progressos consideráveis têm sido descritos no desenvolvimento de métodos para evitar ou tratar a DECH aguda e crônica, as quais foram definidas após as características clínicas e patológicas dessas síndromes serem descritas em 1980 (65).

Essa complicação ganhou destaque quando recomendações do Instituto Nacional de Saúde (NIH) na conferência consenso sobre DECH foram publicadas em 2005-2006 (66-71). O documento produzido pelo consenso tinha três objetivos principais, primeiro definir critérios para diagnóstico de $\mathrm{DECH}$, definir um novo sistema de pontuação para a severidade da doença em cada órgão afetado (score clínico) e o NIH reconheceu duas principais categorias de $\mathrm{DECH}$, cada uma com duas subcategorias (66).

DECH aguda foi dividida em aguda "clássica" quando tem início inferior a 100 dias, a DECH crônica foi separada não apenas pelo tempo após o HSCT, mas também pela presença de critérios diagnósticos ou por achados distintos suportados por biópsia ou outros procedimentos. A DECH crônica clássica foi definida por manifestações crônicas na ausência de anormalidades como eritema cutâneo, função 
hepática anormal ou manifestações gastrointestinais típicas da aguda e a outra forma de crônica foi definida como uma sobreposição entre aguda e crônica $(66,72)$.

A patogênese da DECH envolve proliferação e ativação de linfócitos T e B alo e autorreativos, geração inapropriada de tolerância central e periférica e vários mecanismos inespecíficos de inflamação (73). O desenvolvimento e severidade da DECH nos receptores de transplante dependem de fatores como a idade, toxicidade do regime de condicionamento e técnicas de profilaxia (73).

As primeiras descrições de DECH aguda vieram após investigações sobre a capacidade da radiação de inibir a função da MO em 1950, quando ratos foram tratados com radiação e receberam esplenócitos de um doador não-congênito para facilitar à repopulação celular, porém, uma doença caracterizada pela perda progressiva de peso, postura arqueada, diminuição da atividade e diarréia foi notada (74). Inicialmente chamada de "doença secundária" ou "Runting" para diferenciar da toxicidade inicial do regime de condicionamento e sua aplasia resultante. $\mathrm{O}$ trabalho subseqüente indicou que as células $\mathrm{T}$ do doador no hospedeiro foram importantes mediadores da DECH (75-77).

Esta doença é resultado da interação complexa entre as células do sistema imune de ambos, doador e receptor. A fisiopatologia desse processo consiste em várias fases: $\left(1^{\circ}\right)$ o tratamento induz dano tecidual que leva a inflamação e posterior ativação de células apresentadoras de antígenos (APCs) e células T; $\left(2^{\circ}\right)$ a ativação das células $\mathrm{T}$ do doador leva a expansão clonal de células $\mathrm{T}$ efetoras; $\left(3^{\circ}\right) \mathrm{o}$ recrutamento das células $\mathrm{T}$ ativadas para os tecidos do receptor onde a inflamação leva a destruição dos tecidos (63).

A DECH aguda é considerada uma resposta imune dirigida principalmente por células Th1 e Th17, já a crônica é caracterizada como sendo predominantemente mediada por células Th2 (73) e também envolvendo resposta citotóxica mediada por células $\mathrm{T}$ aloreativas do doador contra tecidos do receptor e mediados por fatores secretados (perforinas, granzimas e citocinas inflamatórias) e de proteínas de superfície celular (FAS e FASL) (63).

Os alvos clássicos da DECH aguda são a pele, trato intestinal e fígado, já a crônica pode também atingir outros órgãos (olhos, mucosa oral, pulmão e trato 
genital) e mimetiza doenças autoimunes, como miastenia gravis ou citopenias autoimunes (78).

O dano tecidual causado por células $\mathrm{T}$ citotóxicas leva ao recrutamento de outras células efetoras, incluindo células NK e neutrófilos, que podem aumentar o dano tecidual e resultar em um estado de autoperpetuação que é difícil de controlar uma vez iniciado. A seqüência de eventos que levam ao desenvolvimento da DECH tem sido amplamente definida pelo uso de modelos animais. Trabalhos iniciais estabeleceram que a célula T alorreativa é a principal causa da doença $(79,80)$.

É importante ressaltar que a DECH é o resultado de uma resposta mediada por $\mathrm{T}$ virgem, visto que as células $\mathrm{T}$ de memória central e periféricas parecem não induzir, entretanto elas mediam a resposta do enxerto versus tumor (GvT), ou efeito mais conhecido como resposta do enxerto versus a leucemia (GvL) (81).

Ambas as células T, CD4 e CD8, do doador possuem um papel importante na sua patogênese. Assim, as técnicas mais efetivas para a prevenção e terapia desta doença focam na depleção, tolerização ou incapacitação funcional de células $\mathrm{T}$ do doador.

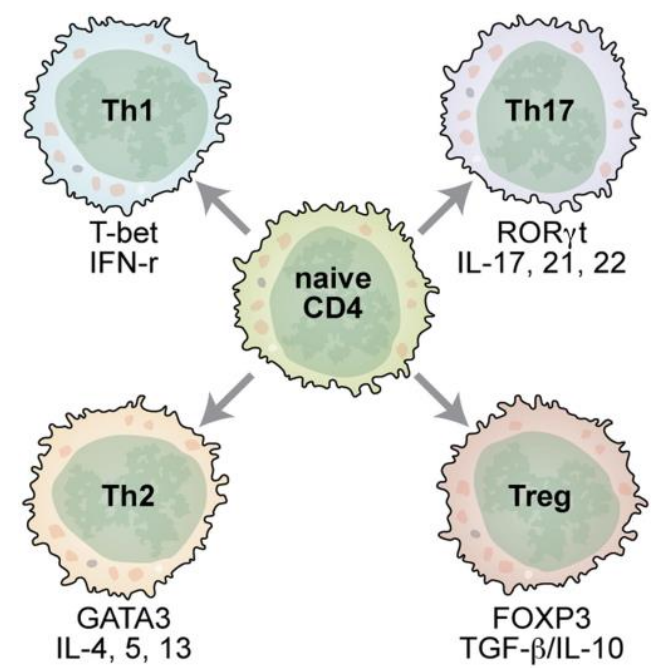

Figura 1 - Células T CD4+ antígeno-ativadas adquirem vários fenótipos determinados por citocinas e fatores de transcrição (82) 


\subsection{Células-Tronco Mesenquimais}

Células precursoras estromais multipotentes foram primeiramente descritas por Friedentstein e colaboradores em 1968, ele descreveu seu isolamento a partir de MO e caracterizou-as como células que proliferam in vitro de forma aderente ao plástico e de aparência fibroblástica capazes de formar colônias e diferenciar em osteócitos, condrócitos e adipócitos in vitro e in vivo (83-86).

Como resultado da suposta capacidade de auto-renovação e diferenciação, as células estromais derivadas de MO foram consideradas células-tronco por Caplan e chamadas de células-tronco mesenquimais (MSC) (87).

As MSCs podem ser obtidas a partir de vários tecidos como, por exemplo: MO, tecido adiposo e placenta. As MSCs possuem uma ampla capacidade de autorenovação in vitro e manutenção de sua multipotência. Por apresentarem capacidade de se diferenciar em células de linhagem mesodérmica acredita-se que elas possam ter um importante papel na reparação tecidual (88-91) e também se diferenciam em células de linhagem endodérmica e possuem um potencial de diferenciação neuroectodermica $(92,93)$.

Apesar da evidência de que as MSCs podem transdiferenciam em vários tipos de células, in vitro e in vivo, a contribuição real dessas células para a reparação de tecidos ainda não esta bem estabelecida (94).

\subsubsection{REgulaÇão IMUNE POR CÉlULAS-TRONCO MESENQUimais}

Recentemente, o potencial imunomodulatório de MSCs tornou-se o foco de vários estudos. Mais precisamente após Le Blanc e colaboradores descreverem um relato de caso de paciente com DECH aguda que recebeu infusão contendo MSC e em 2004, após duas infusões, o paciente apresentou melhora expressiva com redução do quadro da doença e nenhum efeito adverso foi reportado (95).

Mais tarde, estudo clínico de fase II realizado pelo mesmo grupo, mostrou que a taxa de resposta ao tratamento de DECH com MSC foi maior que 70\% e a eficiência do tratamento não estava relacionada ao grau de correspondência de HLA (96). 
Existem diferenças nas vias de sinalização relacionadas à imunomodulação entre MSCs derivadas de humanos e de modelo animal (97), porém, embora por vias diferentes tanto as MSCs de camundongos, macacos e humanos parecem ter efeitos semelhantes na inibição de proliferação de linfócitos (98).

Na presença de MSCs, a resposta de células T estimuladas por aloantígenos (99-101), antígenos peptídicos (102) mitógenos (101) e com anticorpos CD3/CD28 tem sido testadas e os resultados sugerem que este efeito imunossupressor das MSCs é inespecífico e através da inibição da proliferação de linfócitos.

Além disso, as MSCs possuem uma ampla gama de efeitos moduladores sobre células do sistema imune inato e adaptativo (97, 103). Elas podem inibir a proliferação de linfócitos T CD4 e T CD8 e modular suas respostas funcionais levando a uma diminuição da produção de IFN- $\gamma$, IL-2 e TNF- $\alpha$ e um aumento da secreção de IL-4 (100). As MSCs também podem induzir a diferenciação de células Tregs por liberação de citocinas (TGF $\beta$ e/ou IL-10), metabólitos, como a prostaglandia E2 (PGE2) ou enzimas, como a indoleamina-2,3-dioxigenase (IDO), que suprimem respostas citotóxicas (104). Além do efeito sobre as células T, as MSCs também podem atuar inibindo a diferenciação e proliferação de células B $(105,106)$.

Por outro lado, as MSCs ativadas podem bloquear a maturação de DCs (107), que são essenciais na indução da imunidade e tolerância, além de suprimirem a proliferação e citotoxicidade de células NK (108).

Para que as funções imunomoduladoras das MSCs sejam ativadas, existem relatos sobre a necessidade de ativação prévia por células imunes, através da secreção de citocinas pró-inflamatórias, como o IFN- $\gamma$ sozinho ou em combinação com TNF- $\alpha$, IL-1 $\alpha$ ou IL-1 $\beta$ (109, 110). Até o momento não se compreende totalmente como as MSCs exercem suas funções reguladoras, mas parecem ser mediados por ativação cumulativa de vários fatores solúveis como a IDO $(99,111)$, PGE2 (100, 112, 113) ou IL-6 $(103,114)$, fatores secretados pela própria MSCs após ativação (115).

Recentemente, um estudo demonstrou que as MSCs secretam diversas citocinas e além de promoverem a angiogênese também apresentam efeitos na quimiotaxia e apoptose celular (116). Além disso, citocinas como a IL-7, descrita 
como citocina secretada por células estromais, também é importante para a proliferação homeostática e sobrevivência de linfócitos $\mathrm{T}$ virgens, embora o seu mecanismo de ação não tenha sido completamente elucidado $(38,39)$.

Vários pesquisadores têm demonstrado a plasticidade das MSCs humanas em modelos animais e em ensaios clínicos $(117,118)$. No entanto, ainda existem poucos ensaios pré-clinicos e clínicos, o que limita o conhecimento (118). Diversos estudos sobre as atividades imunomoduladoras das MSCs foram documentados, mecanismos contato-dependente e fatores solúveis parecem colaborar para a indução da resposta imunomoduladora, porém os mecanismos ainda são parcialmente conhecidos (119). 


\section{HIPÓTESE}

Nossa hipótese é que por mecanismos não completamente definidos, as células-tronco mesenquimais são capazes de regular respostas altamente inflamatórias de linfócitos ativados.

\section{RELEVÂNCIA}

A DECH aguda apresenta um impacto muito grande no Sistema Único de Saúde (SUS) por ser uma das causas de prolongadas internações no pós-transplante de MO, bem como uma das principais causas de reinternação dos pacientes transplantados, de acordo com a portaria $n^{\circ} 1317 / G M$. Embora tenha sido descrita a identificação de DECH aguda por citocinas e fatores de transcrição, bem como a sugestão de que as MSCs estariam envolvidas na sua supressão de Th1 e Th17, esses trabalhos, em sua maioria, foram realizados em modelos animais. Existem variações significantes entre resultados obtidos em modelos animais e os resultados provenientes do sistema imunológico humano, devido a uma série de fatores como a diferente proporção entre os subtipos de linfócitos, receptores de NK, expressão de receptores toll-like, moléculas co-estimulatórias, produção e função de citocinas e quimiocinas (120).

Portanto, este estudo permite contribuir na investigação de MSCs humanas na supressão de respostas Th1 e Th17, verificando se algum dos achados em modelos animais corresponde ao que acontece em células humanas, além de investigar vias de sinalização envolvidas na imunomodulação induzida pelas MSCs, auxiliando no desenvolvimento e seleção de novas terapias para a DECH aguda e contribuir para o conhecimento em outras patologias onde ocorre a exacerbação da resposta imunológica. 


\section{OBJETIVOS}

\subsection{ObJetivo GeraL}

Objetivo geral do trabalho foi avaliar se ocorre mudança no padrão de resposta dos linfócitos, bem como, alteração e ativação de vias de sinalização após co-cultivo com células-tronco mesenquimais.

\subsection{ObJETIVOS EsPecíficos}

Os objetivos específicos foram:

$\checkmark$ Avaliar alteração no perfil imunofenotípico de linfócitos em co-cultivo;

$\checkmark$ Investigar fatores de transcrição relacionados com o tipo de resposta (T-bet, GATA-3, RORyt e FoxP3) de linfócitos em co-cultivo;

$\checkmark$ Avaliar a proliferação e apoptose de linfócitos em co-cultivo;

$\checkmark$ Avaliar sua capacidade de produzir, secretar e/ou responder a citocinas e

$\checkmark$ Investigar citocinas produzidas por MSC. 


\section{MATERIAIS E MÉTODOS}

\subsection{OBTENÇÃo DE CÉlULAS-TRONCO MESENQUIMAIS}

As células-tronco mesenquimais (MSC) foram obtidas de medula óssea a partir da lavagem de filtros de coleta de medula óssea de acordo com a aprovação do comitê de ética em pesquisa do Hospital Israelita Albert Einstein e da Faculdade de Medicina da Universidade de São Paulo, registrado na Plataforma Brasil sob o CAAE número: 06592712.4.0000.0071 (Anexos 9.1 e 9.2) (121).

Resumidamente, os filtros foram lavados com o meio de cultura (Mc1) que consiste em: Meio de cultura Meio de Dulbeco Modificado (DMEM) (Gibco, Carlsbad, CA) suplementado com $10 \%$ de soro bovino fetal (FBS) (Gibco, Carlsbad, CA), $1 \%$ antibiótico-antimicótico que contém 10000 unidades $/ \mathrm{mL}$ de penicilina, $10000 \mu \mathrm{g} / \mathrm{mL}$ de streptomicina, and $25 \mu \mathrm{g} / \mathrm{mL}$ de Fungizon® (Gibco, Carlsbad, CA) e $1 \%$ de L-glutamina 200mM (Gibco, Carlsbad, CA).

Após a lavagem dos filtros o material coletado foi colocado sobre uma camada de Ficoll-Paque® densidade de 1.077 (GE Healthcare, United Kingdom) e centrifugado 30 minutos a $22^{\circ} \mathrm{C}$ e $500 \mathrm{~g}$, sem breque, de modo a obter-se uma fração isolada de células linfomononucleares de medula óssea.

Após a primeira centrifugação foi removida a camada em suspensão contendo as células linfomononucleares (LMN), estas células foram diluídas com Mc1 e seguida de segunda centrifugação por 10 minutos a $22^{\circ} \mathrm{C}$ e $500 \mathrm{~g}$. Após a segunda centrifugação as células foram ressuspensas em Mc1, cerca de $1 \times 10^{6} / \mathrm{ml}$, e distribuídas em frascos de cultura de $25 \mathrm{~cm}^{2}$, cerca de $5 \mathrm{~mL} /$ frasco de cultura. Os frascos de cultura foram colocados em estufa de $5 \% \mathrm{CO}_{2}$ a $37^{\circ} \mathrm{C}$.

Após 48 horas do plaqueamento, foi realizada a primeira troca do meio de cultura, desprezando-se as células que não aderiram à superfície plástica das garrafas de cultura. As próximas trocas de meio de cultura ocorreram em dias alternados. As células aderidas ao plástico foram consideradas na passagem zero (P0) e a cada replaqueamento as células avançaram uma passagem, prosseguindo para $\mathrm{P} 1$, depois para P2 e assim sucessivamente. Todos os procedimentos realizados utilizaram MSCs entre a $3^{\mathrm{a}}$ e $5^{\mathrm{a}}$ passagens, preferencialmente na $4^{\mathrm{a}}$ passagem. Todas as células 
obtidas foram testadas para contaminação aeróbica, anaeróbica e para Mycoplasma $s p$.

\subsection{Plaqueamento de CÉlulas-Tronco MeSEnQuimais}

Todos os frascos de cultura cujas MSCs atingiam cerca de $80-90 \%$ de confluência foram replaqueados ou congelados. O replaqueamento consistiu da remoção do meio de cultura, lavagem da superfície celular do frasco 02 vezes com tampão fosfato sem cálcio ou magnésio (DPBS) (Gibco, Carlsbad, CA), seguido pela adição de $1-2 \mathrm{~mL} / 25 \mathrm{~cm}^{2}$ de tripsina (TrypLE ${ }^{\mathrm{TM}}$ express - Gibco, Carlsbad, CA), , e incubação por 5 minutos na estufa de $5 \% \mathrm{CO}_{2}$ a $37^{\circ} \mathrm{C}$. Após as células se soltarem do frasco de cultura, foi adicionado cerca de $6 \mathrm{~mL}$ de $\mathrm{Mc} 1$, as células foram transferidas para um tubo cônico de $15 \mathrm{~mL}$ e centrifugadas 10 minutos a $22^{\circ} \mathrm{C}$ e $500 \mathrm{~g}$. As células foram novamente plaqueadas na proporção de 1:3 e os frascos de cultura foram recolocados na estufa de $5 \% \mathrm{CO}_{2}$ a $37^{\circ} \mathrm{C}$. .

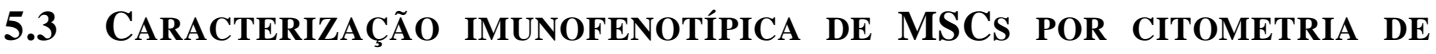 FLUXO}

Após a remoção das MSCs das garrafas de cultura na $4^{\mathrm{a}}$ passagem, as células foram submetidas à centrifugação por 5 minutos, $22^{\circ} \mathrm{C}$ a $500 \mathrm{~g}$. Em seguida, o sobrenadante foi descartado, as células foram homogeneizadas e ressuspendidas em $1 \mathrm{~mL}$ do tampão de lavagem para citometria $(\mathrm{C} 1)$ : tampão fosfato sem cálcio e sem magnésio DPBS (Gibco, Carlsbad, CA), 1\% de albumina humana (Grifols, Barcelona, Espanha) e 0,1\% azida sódica (Sigma, St Louis, MO).

As células foram então submetidas à marcação com anticorpos monoclonais, CD14-FITC (clone: M5E2; BD Pharmingen, San Diego, CA), CD29-PE (clone: MAR4; BD Pharmingen, San Diego, CA), CD31-PE (clone: WM59; BD Pharmingen, San Diego, CA), CD34-PE (clone: 581; BD Pharmingen, San Diego, CA), CD44-PE (clone: 515; BD Pharmingen, San Diego, CA), CD45-PerCPCy5 (clone: 2D1; Biosciences - San Jose - CA), CD73-PE (clone: AD2; BD Pharmingen, San Diego. CA), CD90-APC (clone: 5E10; BD Pharmingen, San Diego. CA), CD106- FITC (clone: 51-10C9; BD Pharmingen, San Diego, CA), CD166-PE (clone: 
3A6; BD Pharmingen, San Diego, CA), HLA-DR-PerCP-Cy5 (clone: L243; Biosciences, San Jose, CA) e CD105-PE (clone: 43A3; Biolegend, San Diego, CA). E os controles isotípicos correspondentes.

Após a marcação, todos os tubos foram submetidos à incubação por 30 minutos no escuro em temperatura ambiente. Em seguida, o material foi lavado em PBS (centrifugação de $500 \mathrm{~g}$ por 5 minutos) ressuspendido em cerca de $200 \mu 1$ da solução $\mathrm{C} 1$, A aquisição das amostras foi realizada no citrometro de fluxo FACS ARIA, foi adquirido no mínimo 10.000 eventos por tubo.

A análise dos fenótipos celulares foi realizada utilizando o "software" BD FACSDiva 6.1.3 (BD Biosciences, San Jose, CA) ou FLOWJO (TreeStar, Ashland, OR).

\subsection{DIFERENCIAÇÃO DAS CÉLULAS-TRONCO MESENQUIMAIS}

As MSCs foram diferenciadas em 3 linhagens celulares, osteoblastos, adipócitos e condrócitos utilizando protocolos específicos listados a seguir.

\subsubsection{PRotocolo DE DIFERENCIAÇÃo ADIPOGÊNICA}

Para a indução de diferenciação adipogênica, as MSCs em P4 foram plaqueadas em placa de cultura contendo 06 poços, após atingirem confluência próxima de $80 \%$, o meio de cultura foi substituído por meio de indução adipogênica, constituído por alpha-MEM (Gibco, Carlsbad, CA) suplementado com 10\% FBS (Gibco, Carlsbad, CA), 1\% Antibiótico-Antimicótico (Gibco, Carlsbad, CA), 1 $\mu \mathrm{M}$ dexametasona (Sigma, St Louis, MO), 100ug/mL de isobutil-metil-xantina (IBMX)

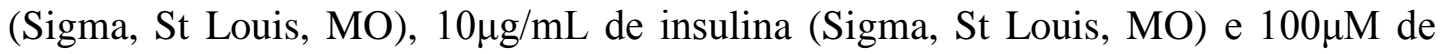
indometacina (IDT) (Sigma, St Louis, MO). O meio de indução adipogenica foi substituído em dias alternados durante 21 dias. A diferenciação foi evidenciada com coloração imuno-histoquimica de oil-red. 


\subsubsection{PROTOCOLO DE DIFERENCIAÇÃo OSTEOGÊNICA}

Para a indução de diferenciação osteogênica, as MSCs em P4 foram plaqueadas em placas de cultura contendo 06 poços. Após atingirem confluência próxima de $80 \%$, o meio de cultura foi substituído por meio de indução osteogênica, constituído por alpha-MEM (Gibco, Carlsbad, CA), suplementado com 10\% FBS FBS (Gibco, Carlsbad, CA), 1\% Antibiótico-Antimicótico (Gibco, Carlsbad, CA), $1 \mu \mathrm{M}$ dexametasona (Sigma, St Louis, MO), $2 \mu \mathrm{g} / \mathrm{mL}$ acido ascórbico (Sigma, St Louis, MO) e 10 $\mu \mathrm{M}$ de beta-glycerol-fosfato (Sigma, St Louis, MO). O meio de indução osteogênica foi substituído em dias alternados durante 21 dias. A diferenciação foi evidenciada com coloração imuno-histoquimica de alizarin-red.

\subsubsection{PROTOCOLO DE DIFERENCIAÇÃo CONDROGÊNICA}

Para a indução condrogenica, as MSCs em P4 foram plaqueadas em placas de cultura contendo 06 poços. Após atingirem confluência próxima de $80 \%$, o meio de cultura foi substituído por meio de indução meio de indução condrogenica, constituído por alpha-MEM (Gibco, Carlsbad, CA), suplementado com 10\% FBS (Gibco, Carlsbad, CA), $1 \mu \mathrm{M}$ dexamethasone (Sigma, St Louis, MO), 6,25 $\mu \mathrm{g} / \mathrm{mL}$ de insulina (Sigma, St Louis, MO), $2 \mu \mathrm{g} / \mathrm{mL}$ de acido ascórbico (Sigma, St Louis, MO) e 10ng/mL de TGF-b (Sigma, St Louis, MO). O meio de indução condrogênica foi substituído em dias alternados durante 21 dias. A diferenciação foi evidenciada com coloração imuno-histoquimica de toluidine blue.

\subsection{MÉTOdOS DE COLORAÇÃo IMUNO-HISTOQUíMICA}

\subsubsection{OIL-RED}

A análise da diferenciação adipogênica foi demonstrada pela coloração de gotas lipídicas após 21 dias de cultivo. As células foram fixadas com 4\% de paraformaldeído (Sigma, St Louis, MO) por 30 minutos, lavadas e desidratadas em $60 \%$ de isopropanol por $2-5$ minutos e coradas com consistiu de remoção do meio 
de indução adipogênica, $0.5 \%$ oil red (Sigma, St Louis, MO) em 100\% isopropanol. A análise foi realizada por microscopia óptica.

\subsubsection{ALIZARIN-RED}

A análise da diferenciação osteogênica foi demonstrada pela coloração da matriz de cálcio com alizarin-red após 21 dias de cultivo. As células foram lavadas das células com água destilada, e fixadas com $4 \%$ paraformaldeído (Sigma, St Louis, $\mathrm{MO}$ ) por 30 minutos, lavadas com água destilada, coradas com alizarin-red (2g em 100mL de água destilada) pH 4.2 (Sigma, St Louis, MO) por 10 - 15minutos e lavadas vigorasamente com água. Após a secagem da placa a análise foi realizada por microscopia óptica.

\subsubsection{TOLUIDENE-BLUE}

A análise da diferenciação condrogênica foi demonstrada pela coloração da matriz de rica em proteoglicanos com toluidene-blue após 21 dias de cultivo. As células foram fixadas com $70 \%$ de etanol por 1 minuto, $90 \%$ de etanol por 1 minuto e com etanol absoluto por 1 minuto. Então as células foram coradas com toluideneblue (1g de toluidene-blue, $1 \mathrm{~g}$ de borato de sódio em $100 \mathrm{~mL}$ de água destilada) (Sigma, St Louis, MO) por 10 - 15minutos e lavadas vigorosamente com água. Após a secagem da placa a análise foi realizada por microscopia óptica.

\subsection{OBTENÇÃO DE LINFÓCITOS}

Os linfócitos foram obtidos a partir de sangue periférico de doadores voluntários saudáveis após assinatura do termo de consentimento esclarecido de acordo com a aprovação do comitê de ética em pesquisa do Hospital Israelita Albert Einstein e da Faculdade de Medicina da Universidade de São Paulo, registrado na Plataforma Brasil sob o CAAE número: 06592712.4.0000.0071 (Anexos 9.1 e 9.2). Após a coleta, o sangue periférico foi diluído em PBS na proporção de 1:1, 
adicionado a uma camada de Ficoll-Paque ${ }^{\circledR}$ densidade de 1.077 (GE Healthcare, United Kingdom) e submetido à centrifugação por 30 minutos a $500 \mathrm{~g}$. A interface opalescente contendo a fração linfomononuclear foi retirada com auxílio de pipeta, transferida para um novo tubo cônico, a amostra foi lavada com PBS (sem cálcio e sem magnésio - Gibco, Carlsbad, CA), e novamente centrifugada por 10 minutos a 500g. O sobrenadante foi dispensado e as células foram ressuspendidas em PBS novamente centrifugadas 10 minutos a $100 \mathrm{~g}$.

As células foram ressuspendidas em meio de cultura Xvivo 15 (Cambrex, Walkersville, MD) suplementado com 1\% de soro humano AB (Life Technologies, Carlsbad, CA), 1\% Antibiótico-Antimicótico (Gibco, Carlsbad, CA) e colocado em uma placa de cultura por 60 minutos em incubadora de $\mathrm{CO}_{2}$ a $37^{\circ} \mathrm{C}$ com o objetivo de eliminar células aderentes ao plástico, como monócitos e macrófagos.

\subsection{CARACTERIZAÇÃO IMUNOFENOTÍPICA DE LINFÓCITOS T}

As células PBMCs foram marcadas com anticorpo monoclonal após a lavagem com $1 \mathrm{~mL}$ do tampão de lavagem para citometria (C1): tampão fosfato sem cálcio e sem magnésio DPBS (Gibco, Carlsbad, CA), 1\% de albumina humana (Grifols, Barcelona, Espanha) e 0,1\% azida sódica (Sigma, St Louis, MO).

Os anticorpos monoclonais utilizados foram: CD3-PerCP-Cy5.5 (clone:SK7; BD Biosciences, CA, San Jose), CD4-APC (clone:RPA-T4; BD Pharmingen, San Diego, CA), CD8-PE (clone: RPA-T8; BD Pharmingen, San Diego, CA), CD45RAFITC (clone:HI100; BD Pharmingen, San Diego, CA), CD45RO-PE (clone:UCHL1; BD Pharmingen, San Diego, CA) e os controles isotípicos correspondentes, para caracterização das sub-populações linfocíticas. As células foram incubadas por 30 minutos a temperatura ambiente e na ausência de iluminação. Após a incubação, as células foram novamente lavadas com $\mathrm{C} 1$, seguidas pela aquisição e análise por citometria de fluxo. Foram adquiridos pelo menos 10.000 eventos por tubo utilizando o Citometro de Fluxo FacsAria (BD Biosciences, San Jose, CA). 


\subsection{PROTOCOLO DE DIFERENCIAÇÃO EM LINFÓCITOS TH17}

Linfócitos $\mathrm{T}$ virgens derivados de sangue periférico, (CD4/CD45RA) foram submetidas à separação por cromatografia de afinidade utilizando o kit de separação indireta para célula CD4 virgem II (Miltenyi biotec, Gladbach, Alemanha) de células $\mathrm{T}$ virgens conforme orientação do fabricante. Brevemente, as células foram marcadas com anticorpos conjugados com microesferas magnéticas CD8, CD14, CD15, CD16, CD19, CD25, CD34, CD36, CD45RO, CD56, CD123, TCR $\gamma / \delta$, HLA-DR e CD235a presentes no kit de separação. As células marcadas foram depletadas, pois ficaram retidas na coluna de separação magnética e as células CD4/CD45RA (células $T$ virgens) não marcadas foram recuperadas, pois passaram livremente pela mesma coluna. Estas células foram colocadas em cultura e estimuladas com microesferas acopladas com anti-CD3/CD28 (Life Technologies, Carlsbad, CA), e cultivadas em meio de cultura Xvivo 15 (Cambrex, Walkersville, MD) suplementado com 1\% de soro humano AB (Life Technologies, Carlsbad, CA), 1\% Antibiótico-Antimicótico (Gibco, Carlsbad, CA) na presença de 10ng/mL de IL1 $\beta$, IL6, IL23 e 5ng/mL de TGF $\beta$ (R\&D Systems, Minneapolis, MN) por 5 dias. As células Th17 foram diferenciadas em presença e ausência de MSCs.

\subsection{CARACTERIZAÇÃo IMUNOFENOTÍPICA dos LinfóCITOS TH17 E TREG POR CITOMETRIA DE FLUXO}

Os linfócitos cultivados para diferenciação Th17 foram transferidos para tubos cônicos de $15 \mathrm{~mL}$ e estimulados com $1 \mu \mathrm{g} / \mathrm{mL}$ de Ionomicina e $50 \mathrm{ng} / \mathrm{mL}$ de phorbol 22-miristato 13-acetato (PMA) e incubados por 4 horas na estufa de $\mathrm{CO}_{2}$ a $37^{\circ} \mathrm{C}$, após este período foi adicionado $10 \mu \mathrm{g} / \mathrm{mL}$ de Brefeldina A (BFA) por tubo seguidos de nova incubação por 2 horas. As células foram centrifugadas a 500g por 10 minutos e ressuspendidas em $1 \mathrm{~mL}$ do tampão de lavagem para citometria $(\mathrm{C} 1)$ : tampão fosfato sem cálcio e sem magnésio DPBS (Gibco, Carlsbad, CA), 1\% de albumina humana (Grifols, Barcelona, Espanha) e 0,1\% azida sódica (Sigma, St Louis, MO). 
Em seguidas as células foram marcadas com os anticorpos monoclonais CD3APC (clone:HIT3a; BD Pharmingen - CA - San Diego), CD4-APC-Cy7 (clone:SK3; BD Biosciences - CA - San Jose), CD45PerCP-Cy5.5 (clone:2D1; BD Biosciences CA - San Jose), CD3-PerCP-Cy5.5 (clone:SK7; BD Biosciences, San Jose, CA), CD4-APC (clone:RPA-T4; BD Pharmingen, San Diego, CA), CD8-PE (clone:RPAT8; BD Pharmingen, San Diego, CA), CD45RA-FITC (clone:HI100; BD Pharmingen, San Diego, CA), CD45RO-PE (clone:UCHL1; BD Pharmingen, San Diego, CA), CCR5-FITC (clone:45502; R\&D System, -Minneapolis, MN), CCR6PE (clone:53103; R\&D System, -Minneapolis, MN), e os controles isotípicos correspondentes, e incubadas por 30 minutos a temperatura ambiente na ausência de iluminação. As células foram lavadas com $\mathrm{C} 1$ e submetidas ao procedimento de fixação e permeabilização para a marcação intracelular.

Foram adicionados $200 \mu \mathrm{L}$ de solução fixadora (BD FACS - lysing solution; BD Biosciences, San Jose, CA) por tubo e incubados por 30 minutos na ausência de iluminação, as células foram lavadas com C1 e nos tubos foram adicionados $200 \mu \mathrm{L}$ de solução permeabilizante (FACS permeabilization solution 2 - BD Biosciences, San Jose - CA) e incubados por 30 minutos na ausência de iluminação. Após lavagem, as células fixadas e permeabilizadas foram marcadas com os anticorpos monoclonais intracelulares IL17A-FITC (clone:N49-653; BD Pharmingen, San Diego, CA), anti-IL17F-PE (clone:O33-782; BD Pharmingen, San Diego, CA), ROR $\gamma$ t-PE (clone:AFKJS-9; eBiosciences, SanDiego, CA), Tbet-PerCP-Cy5.5 (clone:4-46; BD Pharmingen, San Diego, CA) e IFN $\gamma$-FITC (clone:25723.11; BD Biosciences, San Jose, CA) e incubadas por 30 minutos na ausência de iluminação a temperatura ambiente.

Para as células Treguladoras (Treg) as células foram marcadas com os monoclonais CD45-PE-Cy7 (clone:HI-30; BD Pharmingen, San Diego, CA) CD3APC-Cy7 (clone:SK-7; BD Pharmingen, San Diego, CA) CD4-FITC (clone:RPAT4; BD Pharmingen, San Diego, CA) CD25-APC (clone:M-A251; BD Pharmingen, San Diego, CA) e CD127-PercP-Cy5.5 (clone:HIL-7R-M21; BD Pharmingen, San Diego, CA) e incubados por 30 minutos a temperatura ambiente. Em seguida foi realizada a fixação e a permeabilização utilizando o kit FoxP3 (BD Biosciences, San Jose, CA) e a marcação intracelular utilizando o anticorpo FoxP3-PE 
(clone:259D/C7; BD Pharmingen, San Diego, CA), como controle foi realizado o controle de fluorescência menos um (FMO) para CD25-APC and Foxp3-PE..

Após lavagem com $1 \mathrm{~mL}$ de $\mathrm{C} 1$, a análise foi feita em citômetro de fluxo FACSAria com o "software” BD FACSDiva 6.1.3 (BD Biosciences, San Jose, CA) ou FLOWJO (TreeStar, Ashland, OR), sendo que em cada tubo, pelo menos 10.000 eventos foram adquiridos.

\subsection{ENSAIOS DE PROLIFERAÇÃO E MORTE CELULAR}

Para o ensaio de proliferação por KI-67 e detecção de morte por caspase 3 ativada, as células marcadas com anticorpos monoclonais de superfície CD3-PerCPCy5.5 (clone:SK7; BD Biosciences, San Jose, CA), CD4-APC (clone:RPA-T4; BD Pharmingen, San Diego, CA), foram incubadas por 30 minutos a temperatura ambiente na ausência de iluminação e foram lavadas com o tampão (C1): tampão fosfato sem cálcio e sem magnésio DPBS (Gibco, Carlsbad, CA), 1\% de albumina humana (Grifols, Barcelona, Espanha) e 0,1\% azida sódica (Sigma, St Louis, MO).

As células foram submetidas ao procedimento de fixação e permeabilização para a marcação intracelular. Para a fixação e permeabilização celular, foram adicionados $200 \mu \mathrm{L}$ de solução fixadora (lyses buffer - BD) por tubo e incubados por 30 minutos na ausência de iluminação, as células foram lavadas novamente com C1 e nos tubos foram adicionados $200 \mu \mathrm{L}$ de solução permeabilizante (permeabilization solution 2 - BD Biosciences, San Diego, CA) e incubados por 30 minutos na ausência de iluminação. Após lavagem, as células fixadas e permeabilizadas foram marcadas com os anticorpos monoclonais intracelulares KI-67-FITC (clone:B56; BD Pharmingen, San Diego, CA), e Caspase 3 ativada-PE (clone:C92-605; BD Pharmingen, San Diego, CA), e os controles isotípicos correspondentes, e incubadas por 30 minutos na ausência de iluminação, lavadas e analisadas.

Para o ensaio de morte celular, as células foram marcadas com Anexina VFITC (BD Pharmingen, San Diego, CA), Iodeto de propideo (BD Pharmingen, San Diego, CA) e CD3-APC (clone:HIT3a; BD Pharmingen, San Diego, CA). Brevemente, após 15 minutos de incubação, as células foram ressuspendidas em 400 
$\mu \mathrm{l}$ de Annexin V binding buffer (BD Biosciences, San Jose, CA). Todas as amostras foram adquiridas em menos de 30 minutos.

A aquisição e análise foram realizadas em citômetro de fluxo FACSAria com o "software" BD FACSDiva (BD Biosciences, San Jose, CA) ou FLOWJO (TreeStar, Ashland, OR), sendo que pelo menos 10.000 eventos foram adquiridos por tubo.

\subsection{ObTENÇÃo DE MONóCITOS CD14}

Os monócitos foram obtidos a partir de sangue periférico de doadores voluntários saudáveis após assinatura do termo de consentimento esclarecido.

Após a coleta, o sangue periférico foi diluído em PBS (sem cálcio e sem magnésio - Gibco, Carlsbad, CA) na proporção de 1:1, após diluição do sangue, cada $10 \mathrm{~mL}$ deste material diluído foi transferido para um tubo cônico $(15 \mathrm{~mL})$ contendo $5 \mathrm{ml}$ de do grandiente de densidade Ficoll-Paque ${ }^{\circledR}$ densidade de 1.077 (GE Healthcare, United Kingdom). Os tubos foram centrifugados por 30 minutos, 500g. A interface opalescente contendo a fração linfomononuclear foi removida com pipeta, transferida para novo tubo cônico, lavada com PBS e novamente centifugada por 10 minutos a $500 \mathrm{~g}$. O sobrenadante foi dispensado, as células foram ressuspendidas em PBS e centrifugadas novamente por 10 minutos a $100 \mathrm{~g}$.

O sobrenadante novamente foi dispensado e as células linfomononucleares foram submetidas à separação por cromatografia de afinidade (Miltenyi biotec, Gladbach, Alemanha). Para a separação foi utilizado o separador MiniMACS ${ }^{\text {TM }}$ (Miltenyi biotec, Gladbach, Alemanha). As células foram contadas e ressuspendidas em $80 \mu \mathrm{L}$ de solução de solução tampão para cada $10^{7}$ células e $20 \mu \mathrm{L}$ de anticorpo anti-CD14 acoplado à microesferas metálicas para cada $10^{7}$ células (MACS CD14 microbeads), e incubadas por 15 minutos a $4-6^{\circ} \mathrm{C}$. Após a incubação, as células foram lavadas adicionando-se $1 \mathrm{~mL}$ de solução tampão e centrifugadas por 10 minutos a $300 \mathrm{~g}$, descartando-se sobrenadante. As células então foram ressuspendidas em $1 \mathrm{~mL}$ de solução tampão e colocadas em colunas MS (Figura 2A) previamente preparadas e lavadas com $1 \mathrm{~mL}$ de solução tampão. A amostra foi passada através de coluna de separação acoplada a um magneto (Figura 2B), ficando retidas na coluna apenas as células de interesse. Após a passagem das células não desejadas pela 
coluna, as células de interesse CD14 positivas foram obtidas retirando-se a coluna do magneto e pressionando o conteúdo com um embolo (Figura 2C).

Após a obtenção das células CD14+, as mesmas foram cultivadas na densidade de $1 \times 10^{6} / \mathrm{mL}$ e colocadas em cultura para diferenciação em células dendríticas. Uma amostra das células foi colhida para caracterização imunofenotípica por citometria de fluxo.

A

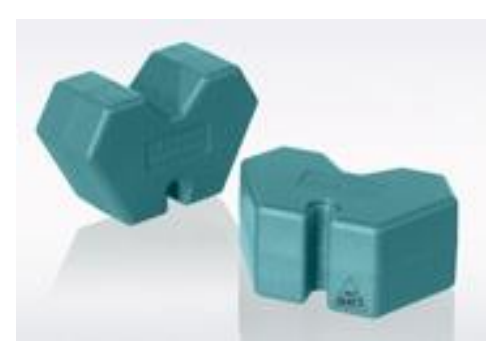

B

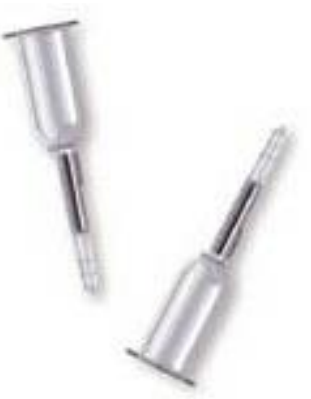

$\mathrm{C}$

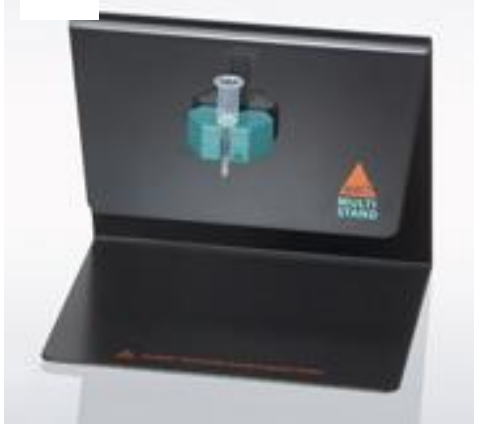

Figura 2 - Separador de células miniMACS (Miltenyi Biotec), utilizado na separação das células CD14+ (Fonte: http://www.miltenyibiotec.com)

\subsection{Protocolo de difERENCIAÇÃo de CÉlulas deNdRítiCAS}

O cultivo das células CD14 selecionadas foi realizado em placa de 6 poços, em cada poço foram cultivadas $1 \times 10^{6}$ células $/ \mathrm{ml}$, sendo o total por poço $2 \times 10^{6}$ células em $2 \mathrm{ml}$ de meio de cultura X-vivo15 (Cambrex, Walkersville, MD) contendo 20 ng/mL IL-4 (R\&D Systems, Minneapolis, MN) e 50 ng/mL GM-CSF (R\&D Systems, Minneapolis, MN). A maturação das células dendríticas foi induzida no sexto dia adicionando os seguintes fatores de maturação: $50 \mathrm{ng} / \mathrm{mL}$ de Fator de necrose tumoral $\alpha$ (TNF- $\alpha$ ) em combinação com $2,7 \mathrm{mM} / \mathrm{mL}$ de Prostaglandina $\mathrm{E}_{2}$ $(\mathrm{TNF} \alpha+\mathrm{PGE} 2)$. 


\subsection{CARACTERIZAÇÃo IMUNOFENOTÍPICA DE MONÓCITOS, CÉlulaS DENDRíticas IMATURAS E CÉLULAS DENDRíticas MADURAS POR CITOMETRIA DE FLUXO}

Os monócitos CD14 foram obtidos por separação magnética, as células dendriticas imaturas foram removidas da cultura no $6^{\circ}$ dia após o início da diferenciação e por fim as células dendríticas maduras foram removidas da cultura após $24 \mathrm{hs}$ de estímulo ministrado no $6^{\mathrm{o}}$ dia após o início da diferenciação Estas células foram retiradas da placa de cultura nestes 3 momentos da diferenciação e submetidas à centrifugação por 5 minutos com rotação de $500 \mathrm{~g}$. Em seguida, o sobrenadante foi descartado, as células foram homogeneizadas e ressuspendidas em $1 \mathrm{~mL}$ de tampão para citometria.

Os experimentos de citometria foram conduzidos utilizando anticorpos monoclonais disponíveis comercialmente. A técnica de coloração foi realizada de acordo com as indicações do fabricante. De maneira geral, uma amostra de $400 \mu \mathrm{L}$, contendo cerca de $4 \times 10^{5}$ células foi distribuída entre 4 tubos, ou seja, cerca de $1 \mathrm{x}$ $10^{5}$ células por tubo, em seguida as células foram marcadas com os anticorpos monoclonais de interesse, depois foram incubadas a temperatura ambiente e protegidas da luz, por 30 minutos, lavadas e ressuspendidas em solução tampão e adquiridas por citometria de fluxo.

Os anticorpos monoclonais utilizados foram: CD14-FITC (clone:M5E2; BD Pharmingen, San Diego, CA), HLA-DR-PerCP Cy5.5 (clone:L243; BD Biosciences, San Jose, CA), CD80-PE (clone:L307.4; BD Pharmingen, San Diego, CA), CD83PE (clone:HB15e; BD Pharmingen, San Diego, CA), CD86-PE (clone:2331 FUN-1; BD Pharmingen, San Diego, CA), CD209-PE (clone:DCN46; BD Pharmingen, San Diego, CA) e os isotipos controles correspondentes. A aquisição de dados foi realizada utilizando o citometro de fluxo FACSARIA e foram adquiridos no mínimo 10.000 eventos por tubo.

Para esta análise foram utilizados os softwares FACSDIVA (BD Biosciences, San Jose, CA) e FLOWJO (TreeStar, Ashland, OR). 


\subsection{Protocolo de CONGelamento E descongelamento de CÉlulas}

As células retiradas da cultura, quando não utilizadas para experimento ou para mudança de passagem foram distribuídas em tubos cônicos de $15 \mathrm{~mL}$, lavadas com PBS e centrifugadas por 10 minutos a 500g. Em seguida o sobrenadante foi descartado e as células foram ressuspendidas numa solução de congelamento, a qual consiste em meio de cultura DMEN, suplementado com $10 \%$ de FBS, $1 \%$ antibiótico-antimicótico que contém 10000 units/mL de penicilina, $10000 \mu \mathrm{g} / \mathrm{mL}$ de estreptomicina e $25 \mu \mathrm{g} / \mathrm{mL}$ de Fungizon ${ }^{\circledR}$ e $1 \%$ de L-glutamina $200 \mathrm{mM}$, acrescido com $10 \%$ de dimetilsulforóxido (DMSO) (Baxter, Galway, Irlanda) e acondicionadas em tubos de criopreservação. As células foram levadas e armazenadas em freezeres de temperatura $-80^{\circ} \mathrm{C}$.

O descongelamento das células de acordo com a necessidade de utilizar as células. As células foram descongeladas em temperatura ambiente e imediatamente transferidaspara tubos cônicos de $15 \mathrm{~mL}$ contendo uma solução de descongelamento, que é constituído pelo meio de cultura DMEM suplementado com $40 \%$ de soro fetal bovino e, então, levadas a centrifugação por 10 minutos a $500 \mathrm{~g}$. O sobrenadante foi descartado e as células ressuspendidas em meio de cultura DMEM suplementado com $10 \%$ de FBS, 1\% antibiótico-antimicótico que contém 10000 unidades/mL de penicilina, $10000 \mu \mathrm{g} / \mathrm{mL}$ de estreptomicina e $25 \mu \mathrm{g} / \mathrm{mL}$ de Fungizon® e $1 \%$ de Lglutamina $200 \mathrm{mM}$ e colocadas novamente em frascos estéreis e levadas e mantidas em cultura.

\subsection{MODELOS UTILIZAdOS IN VITRO}

\subsubsection{CONTROLE POSITIVO - ESTÍMULO COM PHA}

Como modelo de controle positivo de proliferação, adotamos células estimuladas com $1 \mu \mathrm{g} / \mathrm{mL}$ do mitógeno fitohemaglutinina (PHA). Os linfócitos foram estimulados e plaqueados em placas de cultura de seis poços, com meio de cultura Xvivo 15 (Cambrex, Walkersville, MD) suplementado com $1 \%$ de soro humano $\mathrm{AB}$ (Life Technologies, Carlsbad, CA), 1\% Antibiótico-Antimicótico (Gibco, Carlsbad, CA) na densidade de $1 \times 10^{6}$ células por poço em co-cultivo ou não com MSC. O co- 
cultivo também foi realizado utilizando um inserto com microporos de $0.2-0.4 \mu \mathrm{m}$ (Nunc, Anopore - Thermo Scientific Nunc Tissue Culture Inserts, Kamstrup, Dinamarca) para avaliar se os efeitos observados nos linfócitos eram dependentes do contato entre as células.

As células foram mantidas em cultura por 48 horas. Após este período, as células foram coletadas para análise feita em citometro de fluxo com o "software" BD FACSDiva 6.1.3 (BD Biosciences, San Jose, CA) ou FLOWJO (TreeStar, Ashland, OR) , sendo que em cada tubo, pelo menos 10.000 eventos foram adquiridos.

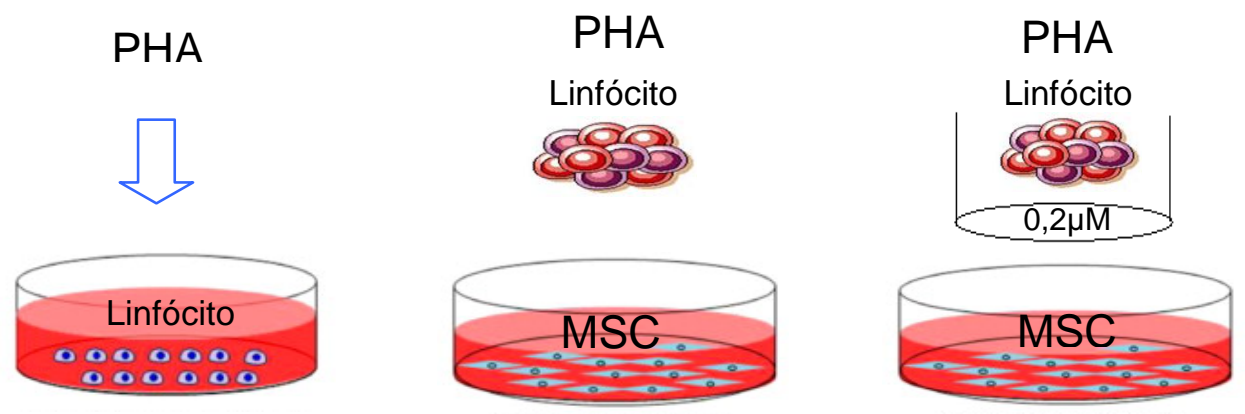

Figura 3 - Representação do modelo de controle positivo

\subsubsection{SimulaÇÃo DECH (MODELO ALOGÊNICO)}

Simulamos uma reação de aloreconhecimento entre linfócitos e células dendríticas e adotamos como modelo in vitro de DECH aguda.

As células dendríticas (DCs) foram irradiadas com 1500 rads e ressuspendidas em meio de cultura X-vivo15 (Cambrex, Walkersville, MD) e distribuídas em placas de cultura com 96 poços de fundo arredondado. Os linfócitos (L) foram acrescidos nessa cultura na proporção de 1:100 (DC:L). As placas foram centrifugadas a $500 \mathrm{~g}$ por 1 minuto. Dessa forma, foram mantidas em cultura por até 72 horas. Após este período, as células foram coletadas para análise de proliferação celular feita em citômetro de fluxo FACSAria com o "software" BD FACSDiva 6.1.3 (BD Biosciences, San Jose, CA) ou FLOWJO (TreeStar, Ashland, OR), sendo que em cada tubo, pelo menos 10.000 eventos foram adquiridos. 


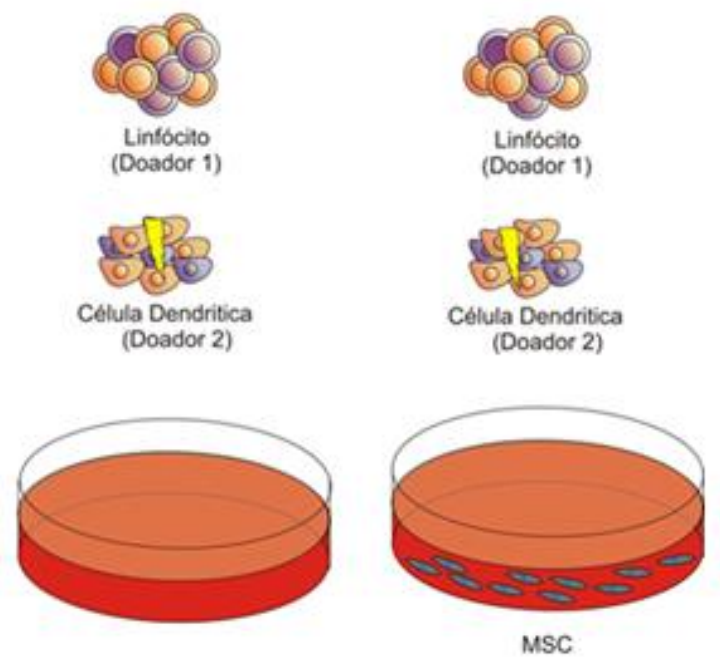

Figura 4 - Representação do modelo de simulação de DECH (Modelo Alogênico)

\subsubsection{Co-Cultivo de CÉlulas Th17}

Para estudo do efeito das células-tronco mesenquimais humanas (MSCs) no fenótipo de linfócitos, foram plaqueadas MSCs em placas de cultura de 6 poços na densidade de $1 \times 10^{5}$ com meio de cultura Meio de Dulbeco Modificado (DMEM) (Gibco, Carlsbad, CA) suplementado com $10 \%$ de soro bovino fetal (FBS) (Gibco, Carlsbad, CA), $1 \%$ antibiótico-antimicótico que contém 10000 unidades $/ \mathrm{mL}$ of penicillin, $10000 \mu \mathrm{g} / \mathrm{mL}$ de streptomycin, e $25 \mu \mathrm{g} / \mathrm{mL}$ de Fungizone ${ }^{\circledR}$ (Gibco, Carlsbad, CA) e 1\% de L-glutamina 200mM (Gibco, Carlsbad, CA) e foram mantidas em cultura até atingirem $70 \%$ de confluência.

Após as MSCs atingirem confluência foram adicionados linfócitos em diferenciação para o padrão Th17, na densidade de $1 \times 10^{6}$ células por poço utilizando meio de cultura X-vivo15 (Cambrex, Walkersville, MD).

As placas foram mantidas em cultura por 48 horas. Após este período, as células foram coletadas para análise de diferenciação para Th17, a secreção de citocinas por citômetro de fluxo FACSAria com o "software" BD FACSDiva 6.1.3 (BD Biosciences, San Jose, CA) ou FLOWJO (TreeStar, Ashland, OR), sendo que em cada tubo, pelo menos 10.000 eventos foram adquiridos. 

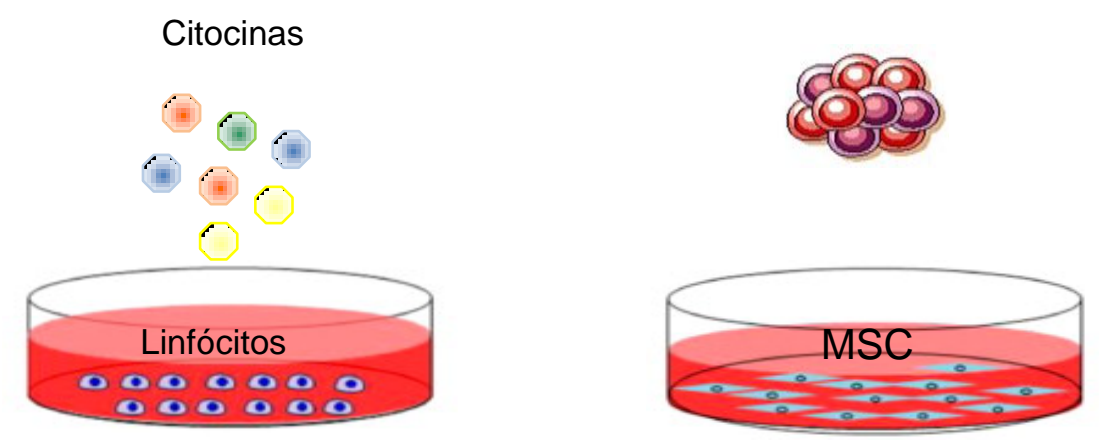

Figura 5 - - Representação do Modelo de co-cultivo com Th17

\subsection{CUlTURA CELULAR COM INDOMETACINA}

Para análise dos efeitos causados pela adição de indometacina a cultura, foram plaqueadas $1 \times 10^{5}$ células-tronco mesenquimais em placas de cultura de 6 poços em meio de cultura Meio de Dulbeco Modificado (DMEM) (Gibco, Carlsbad, CA) suplementado com $10 \%$ de soro bovino fetal (FBS) (Gibco, Carlsbad, CA), $1 \%$ antibiótico-antimicótico que contém 10000 unidades/mL de penicilina, $10000 \mu \mathrm{g} / \mathrm{mL}$ de estreptomicina, e $25 \mu \mathrm{g} / \mathrm{mL}$ de Fungizon® (Gibco, Carlsbad, CA) e 1\% de Lglutamina 200mM (Gibco, Carlsbad, CA) e foram mantidas em cultura até atingirem $70 \%$ de confluência.

Após as MSC atingirem confluência foram adicionados linfócitos estimulados com mitógeno fitohemaglutinina (PHA) na densidade de $1 \times 10^{6}$ células por poço utilizando meio de cultura X-vivo15 (Cambrex, Walkersville, MD). As células foram tratadas com diferentes concentrações de Indometacina (5, 25, 50 e 100ng) para verificar se a adição de uma droga anti-inflamatória reduzia o efeito anti-proliferativo observados em linfócitos na presença de MSC. 


\subsection{CUlTURA CELUlar COM INTERLEUCINA 7 RECOMBINANTE HUMANA E ANTI- INTERLEUCINA 7 POLICLONAL}

Para estudo do efeito da IL-7 nas co-culturas, foram plaqueadas MSC em placas de cultura de 6 poços na densidade de $1 \times 10^{5}$ em meio de cultura Meio de Dulbeco Modificado (DMEM) (Gibco, Carlsbad, CA) suplementado com $10 \%$ de soro bovino fetal (FBS) (Gibco, Carlsbad, CA), 1\% antibiótico-antimicótico que contém 10000 unidades $/ \mathrm{mL}$ de penicilina, $10000 \mu \mathrm{g} / \mathrm{mL}$ de estreptomicina, e 25 $\mu \mathrm{g} / \mathrm{mL}$ de Fungizon ${ }^{\circledR}$ (Gibco, Carlsbad, CA) e 1\% de L-glutamina 200mM (Gibco, Carlsbad, CA) e foram mantidas em cultura até atingirem $70 \%$ de confluência.

Após as MSC atingirem confluência foram adicionados linfócitos estimulados com mitógeno fitohemaglutinina (PHA) na densidade de $1 \times 10^{6}$ células por poço utilizando meio de cultura X-vivo15 (Cambrex, Walkersville, MD).

Foram adicionadas diferentes concentrações de anti-IL-7 policlonal $10 \mathrm{e}$ $20 \mu \mathrm{L}$ (R\&D Systems, Minneapolis, MN) para verificar se o boqueio desta citocina influenciava na resposta dos linfócitos estimulados com PHA. Os linfócitos estimulados com PHA também foram tratados com IL-7 recombinante humano nas concentrações de 10 e 20ng/mL (R\&D Systems, Minneapolis, MN) para comparação com os efeitos observados na presença de MSC.

Os linfócitos foram matidos em co-cultivo com MSC por 48 horas. Após este período, os linfócitos foram incubados por 30 minutos com os marcadores de superfície CD3-FITC (clone:UCHT1; BD Pharmingen, San Diego, CA), CD127PercP-Cy5.5 (clone:HIL-7R-M21; BD Pharmingen, San Diego, CA) e CD4-APC (clone:RPA-T4; BD Pharmingen, San Diego, CA).

A aquisição e analise das amostras foi realizada por citometria de fluxo com o "software" BD FACSDiva 6.1.3 (BD Biosciences, San Jose, CA) ou FLOWJO (TreeStar, Ashland, OR), sendo que em cada tubo, pelo menos 10.000 eventos foram adquiridos. 


\subsection{EnSAIO de PRODUÇão DE IL-7 POR MSC}

Para estudo de produção de citocinas pelas células-tronco mesenquimais humanas (MSCs) co-cultivadas com linfócitos, foram plaqueadas MSC em placas de cultura de 6 poços na densidade de $1 \times 10^{5}$ em meio de cultura Meio de Dulbeco Modificado (DMEM) (Gibco, Carlsbad, CA) suplementado com 10\% de soro bovino fetal (FBS) (Gibco, Carlsbad, CA), 1\% antibiótico-antimicótico que contém 10000 unidades/mL de penicilina, $10000 \mu \mathrm{g} / \mathrm{mL}$ de estreptomicina, e $25 \mu \mathrm{g} / \mathrm{mL}$ de Fungizon ${ }^{\circledR}$ (Gibco, Carlsbad, CA) e 1\% de L-glutamina 200mM (Gibco, Carlsbad, CA) e foram mantidas em cultura até atingirem $70 \%$ de confluência.

Após as MSC atingirem confluência foram adicionados ou não linfócitos estimulados com mitógeno fitohemaglutinina (PHA) na densidade de $3 \times 10^{6}$ células por poço utilizando meio de cultura X-vivo15 (Cambrex, Walkersville, MD).

As placas foram mantidas em cultura por 24 horas e após esse período foi adicionado Befreldina A (BFA) nas culturas para impedir a secreção de citocinas pelas células pelo período de 4 horas. Após este período, as células mesenquimais foram coletadas para análise de produção de citocinas. As células marcadas com anticorpo monoclonal de superfície CD105-PE (clone: 43A3; Biolegend - San Diego - CA) foram incubadas por 30 minutos a temperatura ambiente na ausência de iluminação e foram lavadas com o tampão fosfato sem cálcio e sem magnésio DPBS (Gibco, Carlsbad, CA), 1\% de albumina humana (Grifols, Barcelona, Espanha) e $0,1 \%$ azida sódica (Sigma, St Louis, MO).

As células foram submetidas ao procedimento de fixação e permeabilização para a marcação intracelular. Para a fixação e permeabilização celular, foram adicionados $200 \mu \mathrm{L}$ de solução fixadora (lyses buffer - BD Biosciences, San Diego, CA) por tubo e incubados por 30 minutos na ausência de iluminação, as células foram lavadas novamente com tampão e nos tubos foram adicionados $200 \mu \mathrm{L}$ de solução permeabilizante (permeabilization solution 2 - BD Biosciences, San Diego, CA) e incubados por 30 minutos na ausência de iluminação.

Após lavagem, as células fixadas e permeabilizadas foram marcadas com o anticorpo policlonal intracelular IL-7, incubadas por 30 minutos, lavadas e foi adicionado o anticorpo secundário FITC, seguida de outra incubação de, foram 
realizados os controles isotípicos correspondentes, e incubadas por 30 minutos na ausência de iluminação, lavadas e analisadas por citômetro de fluxo FACSAria com o "software" BD FACSDiva 6.1.3 (BD Biosciences, San Jose, CA) ou FLOWJO (TreeStar, Ashland, OR), sendo que em cada tubo, pelo menos 10.000 eventos foram adquiridos.

\subsection{Análise ESTATístiCa}

Os resultados foram expressos como média \pm desvio padrão. Comparações entre grupos foram realizadas por teste $\mathrm{t}$ de Student e/ou OneWay ANOVA. Foi considerado significativo $\mathrm{p}<0,05$ em todos os experimentos. 


\section{RESULTADOS}

\subsection{PARTE I - ISOLAMENTO E CARACTERIZAÇÃO DE CÉlulaS MESENQUiMAiS DE MEDULA ÓSSEA HUMANA}

A primeira etapa deste trabalho foi estruturar o isolamento e a caracterização das MSC humanas obtidas através da lavagem de filtros de coleta de medula óssea (MO). Nosso grupo publicou um artigo científico (Anexo 9.3), no qual comparou as MSCs obtidas de filtros descartáveis com as MSCs obtidas de filtros reutilizáveis. As MSCs obtidas a partir de ambos os filtros preencheram todos os requisitos da Internacional Society for Cell Therapy (ISCT), tanto para as caracteristicas imunofenotípicas, quanto para a capacidade de diferenciação nas três linhagens de origem mesodérmica. Portanto, as MSCs obtidas a partir de ambos os filtros de coleta de medula óssea foram consideradas adequadas para utilização em pesquisa científica e foram utilizadas no desenvolvimento das etapas seguintes deste estudo (121).

\subsection{Parte II - Efeito das Células-tronco mesenquimais na AtivaÇão E PROLIFERAÇÃO DE LINFÓCITOS.}

\subsubsection{A presença de MSC reduz a ativação de linfócitos estimulados com PHA}

Após o cultivo de linfócitos T com fitohemaglutinina (PHA) por 48 horas, na ausência ou presença das MSC. Os linfócitos TCD4 foram analisados por citometria de fluxo para a expressão de CD25, cadeia $\alpha$ do receptor da citocina IL-2, que indica ativação de linfócitos, e para a expressão de CD69, glicoproteína cuja expressão na superfície celular é aumentada em linfócitos e células NK ativadas, também envolvida com a proliferação dessas células (Figura 6). Notamos que linfócitos estimulados com PHA após 48 horas de cultura na presença de MSC apresentam expressão de CD25 significativamente menor em relação aos linfócitos cultivados na ausência das MSC (Figura 7A), da mesma forma também observamos redução da expressão de CD69 dos linfócitos em co-cultivo com MSC em relação aos na ausência de MSC (Figura 7B). 


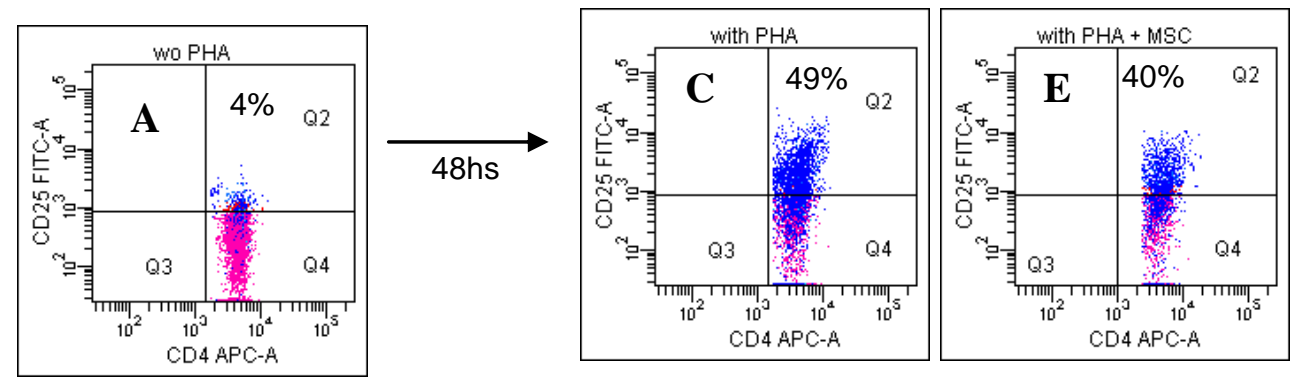

CD69
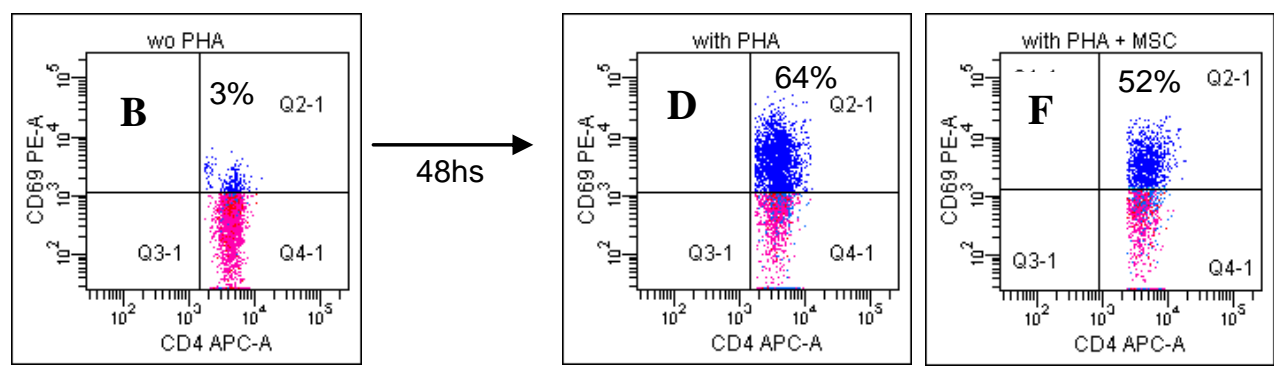

Figura 6 - Estratégia de anáise das populações de linfócitos ativados

A seleção inicial foi realizada em células CD3 positivas em seguidas os linfócitos T (CD3+) foram analisados para expressão de CD4 e CD69 ou CD25. Os linfócitos sem estímulo expressam 4\% de CD25 (A) e 3\% de CD69 (B). Após 48 horas com estímulo de PHA, na ausência de MSC, expressam 49,0\% de CD25 (C) e 64,0\% de CD69 (D). Após 48 horas com estímulo de PHA, na presença de MSC, os linfócitos expressam 40\% de CD25 (E) e 52\% de CD25 (F). (dado representativo de 6 experimentos).

A

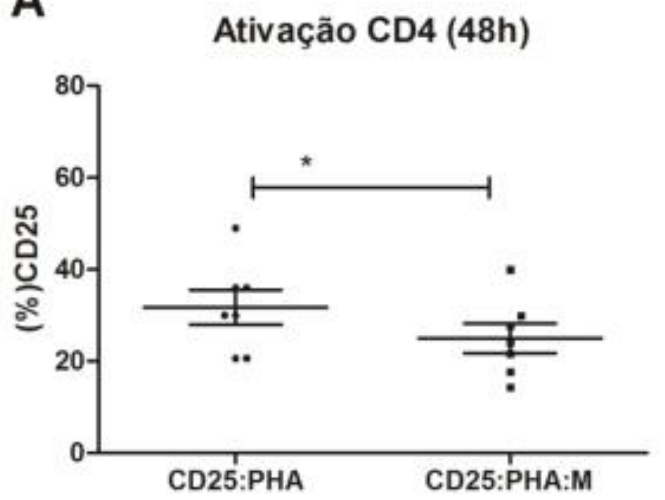

B

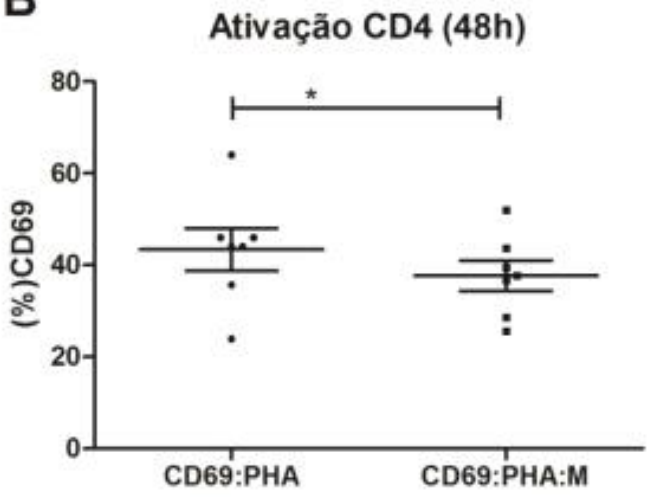

Figura 7 - A presença de MSCs reduz a ativação de linfócitos T CD3 e CD3:CD4

Linfócitos em cultura por 48 horas $(\mathrm{n}=6)$. (A) Linfócitos estimulados com PHA cultivados na presença de MSCs apresentam sua ativação mensurada pela expressão de CD25 (CD25:PHA:M) $25,04 \%+8 \%$ que estava reduzida em relação aos linfócitos cultivados na ausência de MSCs (CD25:PHA), 31,75 $\pm 9 \%$. (B) Linfócitos estimulados por $48 \mathrm{~h}$ com PHA cultivados na presença de MSCs apresentam sua ativação mensurada pela expressão de CD69 (CD69:PHA:M) 37,75 $\pm 9 \%$ que

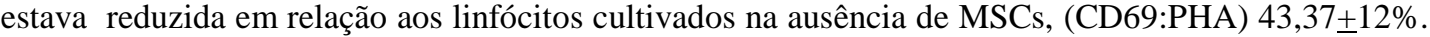
$(* \mathrm{p}<0,05)$. 


\subsubsection{A presença de MSC reduz a proliferação de linfócitos ativados com PHA}

A presença de MSC em culturas de linfócitos estimulados com PHA reduz de maneira significativa a ativação dessas células, o que nos levou a investigar o o efeito das MSCs sobre a proliferação dos linfócitos $\mathrm{T}$, visto que a resposta imunológica pode ser mensurada de acordo com a proliferação dos linfócitos T. Para isso, nós utilizamos o marcador intranuclear KI-67, uma proteína que em humanos é codificada pelo gene MKI67, um marcador de proliferação celular que é expresso em todas as fases do ciclo celular ( $\mathrm{G} 1, \mathrm{~S}, \mathrm{G} 2$ e mitose) e, portanto não expresso em células em repouso (G0), ou seja, está ausente em linfócitos T não ativados ou ciclando (122) (Figura 8).

Para verificar se a presença de MSC alterara a proliferação de linfócitos, nós utilizamos linfócitos estimulados com PHA na ausência ou presença de MSC durante 48 horas de cultura. Observamos que a presença de MSC reduz de maneira significativa a proliferação de linfócitos CD3, CD3CD4 e CD3CD8 quando comparados com linfócitos cultivados na ausência de MSC (Figura 9).
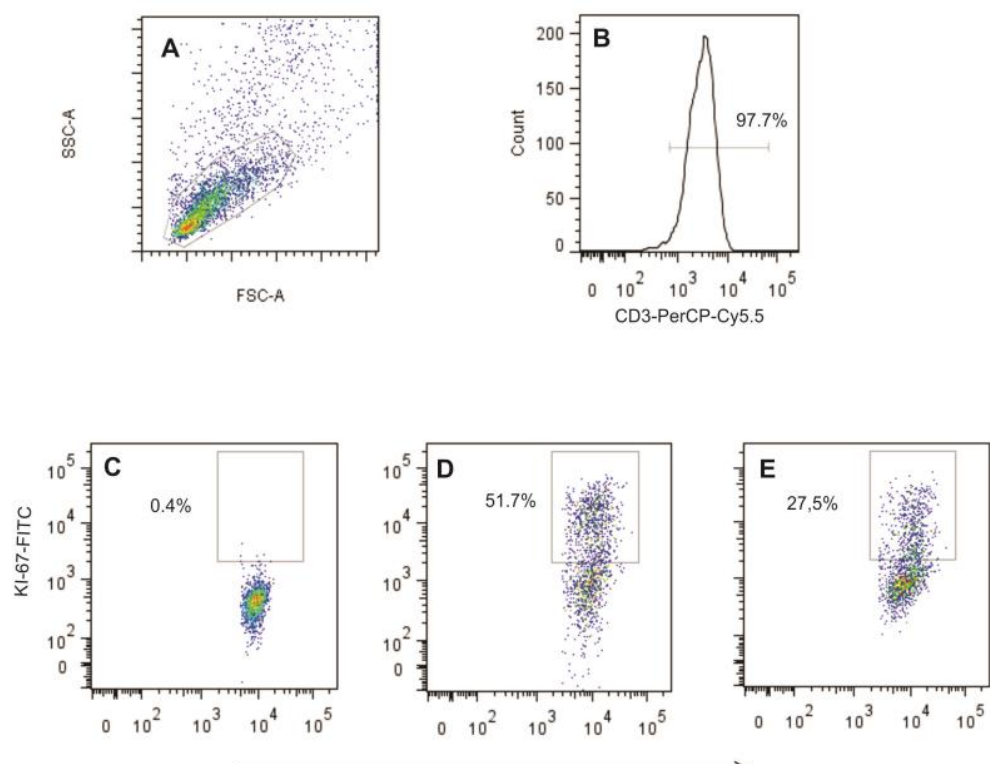

CD3-PerCP-Cy5.5

Figura 8 - Estratégia de análise de proliferação da população de linfócitos

(A) A população de linfócitos foi selecionada de acordo com tamanho e granulosidade, (B) seleção da população positiva para CD3. (C) expressão de KI-67 (0,4\%) em linfócitos T não estimulados (D) expressão de KI-67 em linfócitos T estimulados com PHA (51,7\%) (E) a expressão de KI-67 em linfócitos $\mathrm{T}$ estimulados com PHA na presença de MSC (27,5\%). (dados representativos de 9 experimentos) 


\section{A CD3 Proliferation}

(72h)

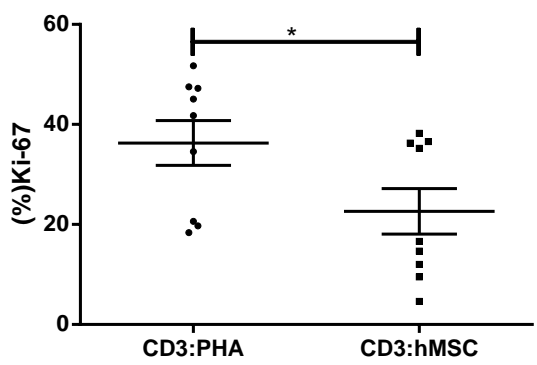

B

Proliferação CD4 (72h)

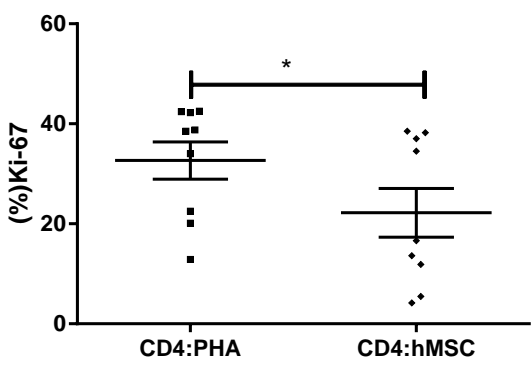

C

Proliferação CD8 (72h)

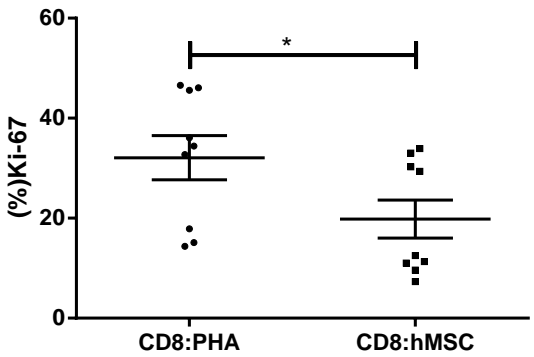

Figura 9 - A presença de MSCs reduz a proliferação de linfócitos T CD3, CD3:CD4 e CD3:CD8 Linfócitos em cultura por 72 horas (n=9). (A) A expressão de KI-67 por linfócitos T (CD3) estimulados com PHA (CD3:PHA) dimunui de $36 \pm 13 \%$ para $22 \pm 13 \%$ na presença de MSC (CD3:hMSC). (B) A expressão de KI-67 em linfócitos T auxiliares (CD4:PHA) diminui de 32 $\pm 11 \%$ para $22 \pm 14 \%$ na presença de MSCs (CD4:hMSC) e (C) A expressão de KI-67 em linfócitos T citotoxicos (CD3:CD8) diminui de $32+13 \%$ para $19+11 \%$ na presença de MSCs (CD8:hMSC) $(* \mathrm{p}<0,05)$. 


\subsubsection{MSC reduzem a proliferação de linfócitos de forma independente de contato}

A seguir verificamos se o efeito antiproliferativo observado era dependente ou não do contato entre as células. Para isso utilizamos um inserto com poros 0,2$0,4 \mu \mathrm{m}$ que impede o contato físico entre as células e permite apenas a passagem de moléculas solúveis.

Observamos que a proliferação de linfócitos na presença de MSC e também na presença de inserto é reduzida quando comparada com a proliferação dos linfócitos T na ausência de MSC. Não há diferença significativa na proliferação de linfócitos T quando em presença de MSC comparada com a presença de MSC e inserto, o que nos permite concluir que a proliferação dos linfócitos é reduzida por molécula solúvel secretada ou depletada do meio (Figura 10).

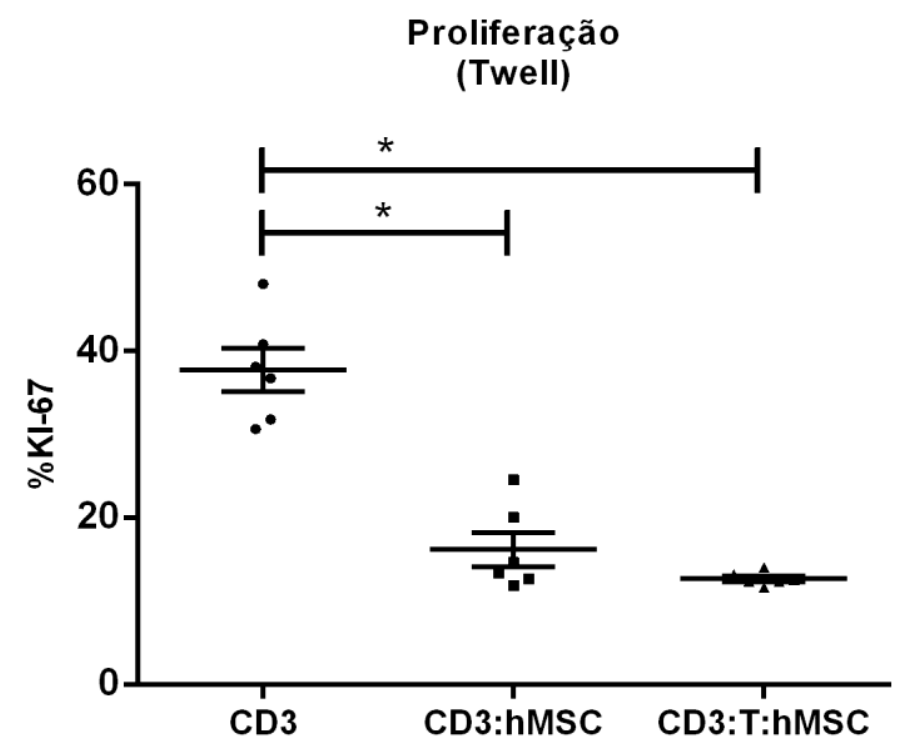

Figura 10 - A presença de MSC reduz a proliferação de linfócitos de maneira contatoindependente

Linfócitos em cultura por 72 horas (n=6). Expressão de KI-67 por linfócitos estimulados com PHA (CD3) foi de 37,66 $\pm 6,3 \%$, quando em presença de MSC (CD3:hMSC) esta expressão diminui para $16,18 \pm 4,9 \%$ e em co-cultivo com MSC na presença de membrana semi-permeável (CD3:T:hMSC) a expressão diminui para $12,63 \pm 0,89 \%) * p<0,05$. 


\subsubsection{Diferenciação de células dendritícas alogenicas para realização de reação mista de linfócitos}

Devido aos achados encontrados na ativação e na proliferação de linfócitos estimulados com PHA, testamos se o efeito antiproliferativo observado não era um efeito inespecífico causado pela utilização do mitógeno. Para isso, nós utilizamos o modelo de DECH in vitro, ou seja, reação mista de linfócitos (MLR) utilizando DCs derivadas de monócitos para estimular linfócitos alogênicos.

A seguir mostramos a diferenciação e maturação de células dendríticas (DCs) a partir de monócitos (Figura 11).
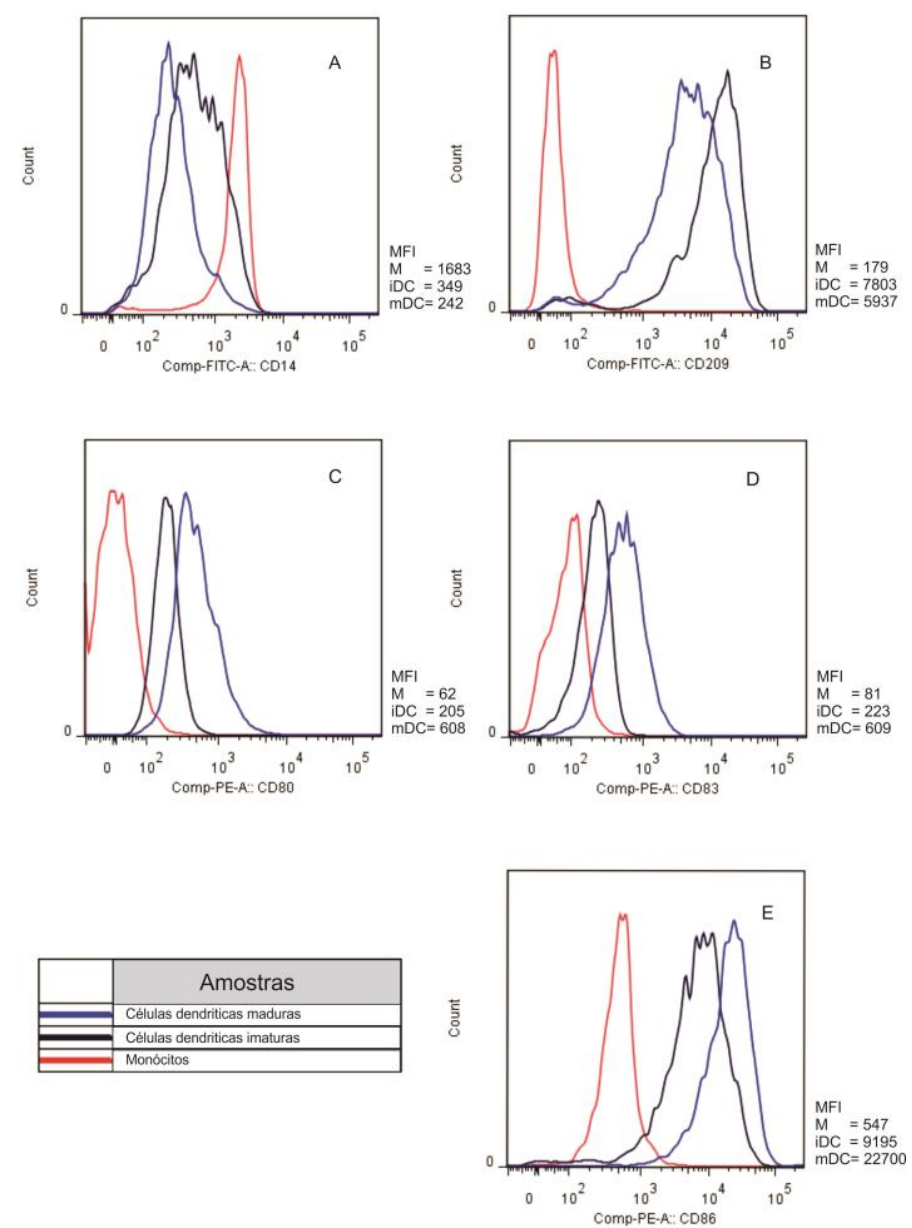

Figura 11 - Caracterização fenotípica de células dendríticas derivadas de monócitos

Para esta análise utilizamos a média de intensidade de fluorescência (MFI), pois achamos que representa melhor as diferenças entre as três condições, monócitos (M), células dendritícas imaturas (iDC) e células dendritícas maduras (mDC). (A) A expressão de CD14 nos monócitos apresentou MFI=1683- (vermelho) e seu decaimento ocorreu conforme a célula se diferenciou em iDC MFI=349 (azul) e mDC MFI=242 (azul claro); (B) Expressão de CD209 nos monócitos MFI=179 (vermelho), seu aumento conforme a célula se diferenciou em iDC MFI=7803 (azul) e mDC MFI=5937(azul claro); (C) Expressão de CD80 nos monócitos MFI=62 (vermelho), seu aumento conforme a célula se 
diferencia em iDC MFI=205 (azul) e mDC MFI=608 (azul claro); (D) Expressão de CD83 nos monócitos $\mathrm{MFI}=81$ (vermelho) e seu aumento conforme a célula se diferenciou em iDC MFI=223 (azul) e mDC MFI=609 (azul claro); (E) Expressão de CD86 nos monócitos MFI=547 (vermelho) e seu aumento conforme a célula se diferenciou em iDC MFI=9195 (azul) e mDC MFI=22700 (azul claro).

\subsubsection{Titulação de linfócitos:DCs para realização de MLR}

O modelo alôgenico (MLR) se caracteriza pela cultura de linfócitos e DCs alogênicas, a percentagem de células $\mathrm{T}$ no sangue periférico que reconhecem aloantígenos e respondem a eles, in vivo e in vitro, está entre 1-10\%. Após a caracterização das DCs, o experimento seguinte foi a padronização das reações entre essas células e os linfócitos alogênicos.

Para isso, utilizamos diferentes proporções de linfócitos T CD3 em relação a DCs $(1: 1,1: 10$ e 1:100) e analisamos os linfócitos T CD3 por citometria de fluxo quanto a expressão nuclear de KI-67. Observamos que houve diferença entre as proporções de 1:1, 1:10 e 1:100. Desse modo, optamos por trabalhar com a proporção de uma DC para cada 100 linfócitos, devido esta proporção induzir maior percentagem de linfócitos proliferando conforme mostrado na Figura 12. 


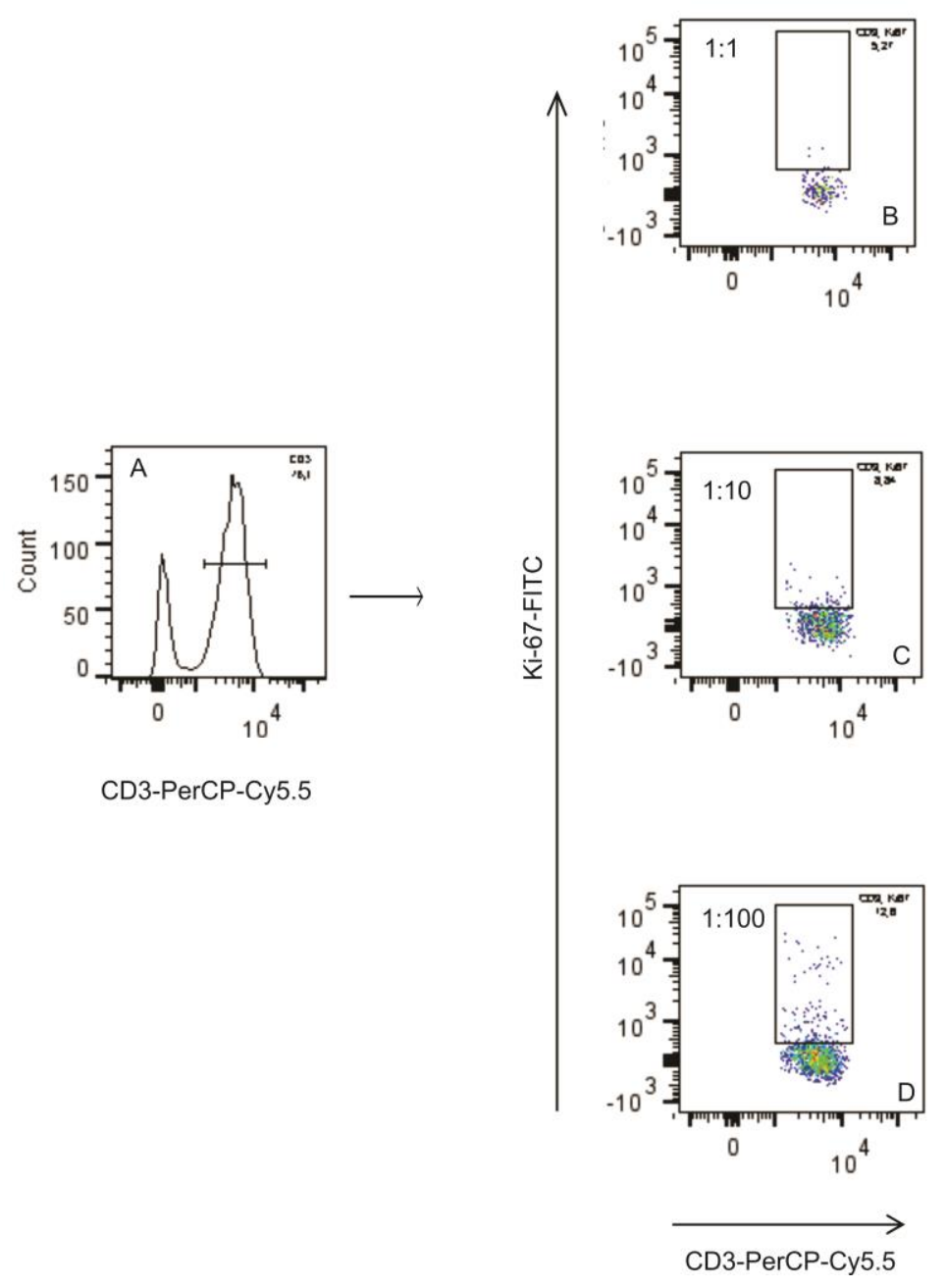

Figura 12 - Padronização de reações alogênicas (MLR)

(A) Estratégia de seleção dos linfócitos T CD3, (B) Proliferação de linfócitos T estimulados por DCs, de acordo com a expressão de KI-67, na proporção 1:1 (DC:linfócito) cerca de 5,2\% linfócitos T expressaram KI-67, (C) para 1:10 cerca de 8,34\% linfócitos T expressaram KI-67 e (D) para 1:100 cerca de $12,6 \%$ linfócitos T expressaram KI-67.

\subsubsection{MSC reduzem a proliferação de linfócitos estimulados com células dendríticas alogênicas}

A seguir invertigamos se a presença das MSC também seria capaz de reduzir a proliferação de linfócitos estimulados com DCs alogênicas. Para isso, utilizamos a reação alogênica de uma DCs para cada 100 linfócitos T e analisamos a expressão do marcador KI-67 em linfócitos T CD3 e CD4 na presença ou não de MSC (Figura 13).

Observamos que, da mesma forma que a presença de MSC reduz a proliferação de linfócitos $\mathrm{T}$ estimulados com PHA, elas também reduzem a 
expressão de KI-67 em linfócitos CD3 e CD4 estimulados por DCs alogenicas após 72 horas de co-cultivo (Figura 14).

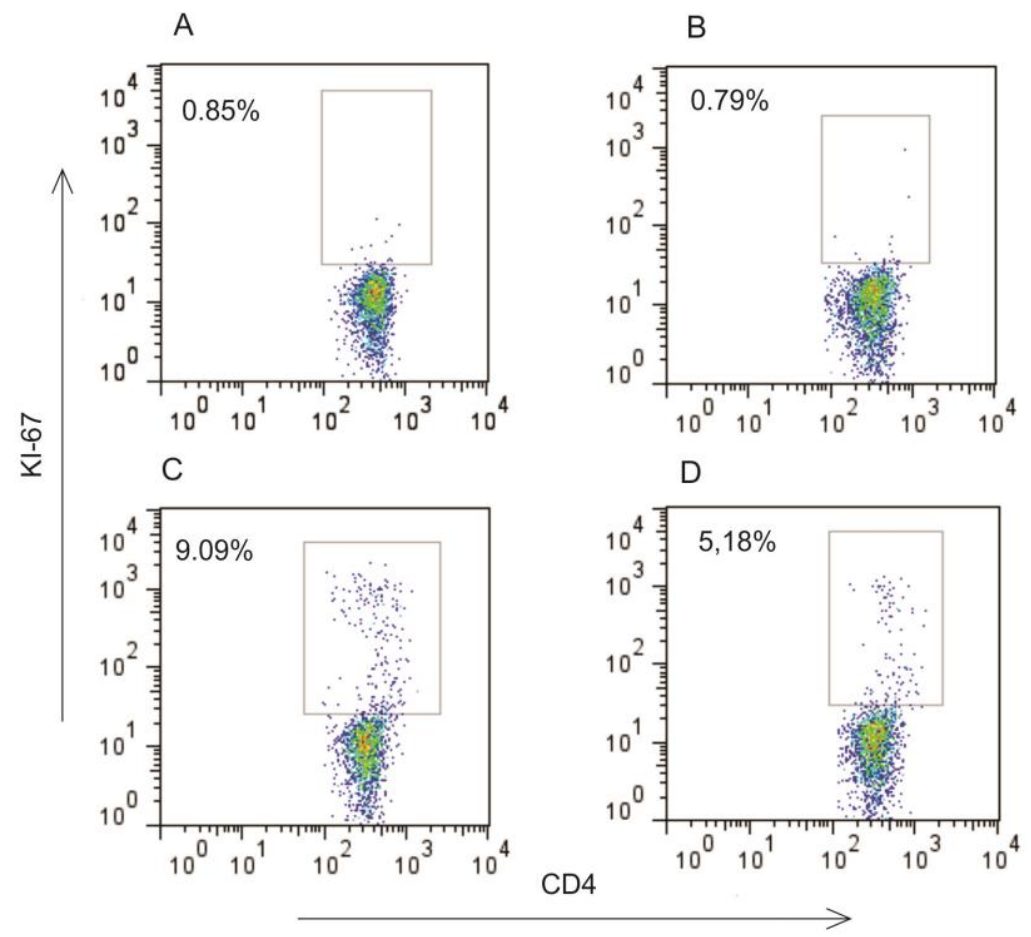

Figura 13 - Estratégia de seleção de população de linfócitos em proliferação

Expressão de KI-67 por linfócitos em cultura por 72 horas. (A) Proliferação de linfócitos CD3:CD4 não estimulados na ausência de MSC $(0,8 \%)$ (B) e presença de MSC $(0,79 \%)(\mathrm{C})$. Proliferação de linfócitos CD3:CD4 estimulados com células dendríticas alogênicas $(9,09 \%)$ (D) na presença de MSCs $(5,18 \%)$ (dado representativo de 3 experimentos).
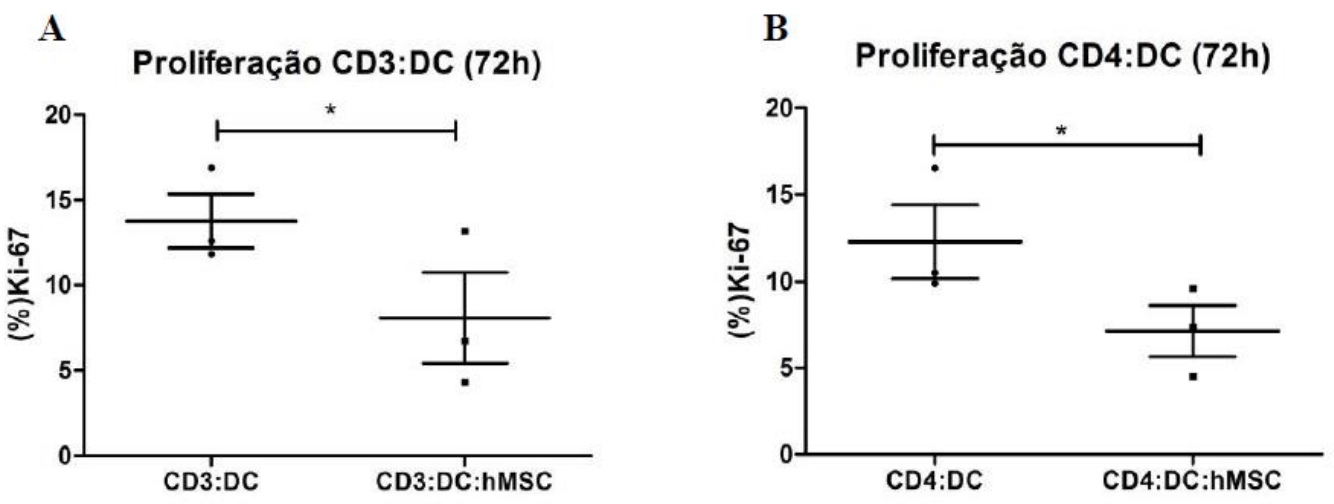

Figura 14 - Presença de MSC reduz a proliferação de linfócitos CD3 e CD3:CD4 alorreativos Linfócitos em cultura por 72 horas $(n=3)$. (A) Redução da expressão de KI-67 por linfócitos T CD3

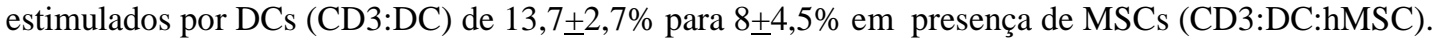
(B) Redução da expressão de KI-67 por linfócitos T CD3:CD4 estimulados por DCs (CD4:DCs) de $12,2 \pm 3,6 \%$ para $7,1 \pm 2,5 \%$ em presença de $\operatorname{MSCs}($ CD $4: D C: h M S C)(* \mathrm{p}<0,05)$. 


\subsubsection{Indometacina potencializa o efeito antiproliferativo de MSC em linfócitos}

Após verificarmos que o efeito antiproliferativo das MSCs em linfócitos T não era exclusivo do estímulo com PHA, mas que também ocorria nas reações alogenicas. Verificamos se a Indometacina (IDT), um anti-inflamatório não esteroidal que age inibindo as enzimas ciclooxigenases I e II, e, portanto impedindo a formação de um importante mediador da inflamação, a prostaglandina E2, era capaz de inibir o efeito antiproliferativo observado. Utilizamos diferentes doses da droga $(0,5,25,50$ e $100 \mathrm{ng} / \mathrm{mL})$ em linfócitos ativados com PHA co-cultivados com MSC.

E diferente do esperado, observamos que a IDT leva a potencialização do efeito modulador de MSCs sobre linfócitos reduzindo ainda mais a proliferação dessas células (Figura 15).

Proliferação

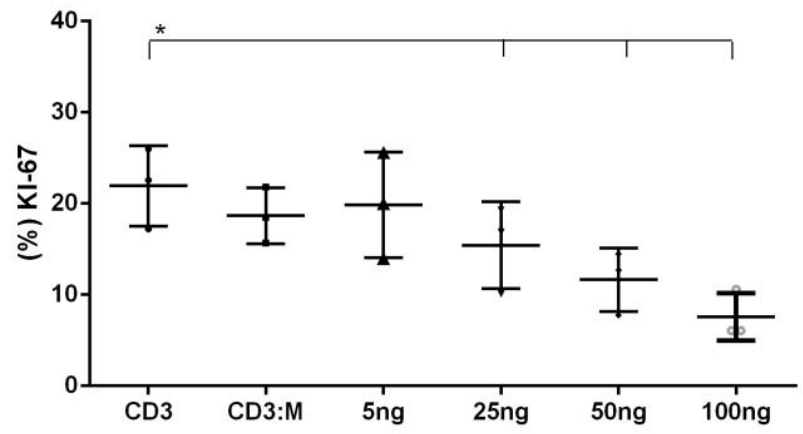

Figura 15 - IDT potencializa efeito antiproliferativo de MSCs em linfócitos ativados com PHA de maneira dose-dependente

Expressão de KI-67 por linfócitos em cultura por 48 horas $(n=3)$. Cultura de linfócitos estimulados com PHA (CD3), em presença de MSC (CD3:M) e acrescida de doses crescentes de IDT (5ng/mL, $25 \mathrm{ng} / \mathrm{mL}, 50 \mathrm{ng} / \mathrm{mL}$ e $100 \mathrm{ng} / \mathrm{mL}$ ). A proliferação em (CD3) foi reduzida de $21,9 \pm 4,4 \%$ para $18,66 \pm 3,4 \%$ pela presença de MSC e a redução foi crescente de acordo com a dose de IDT, $25 \mathrm{ng} / \mathrm{mL}$ $(15,4 \pm 4,7 \%), 50 \mathrm{ng} / \mathrm{mL}(11,65 \pm 3,4 \%)$ e $100 \mathrm{ng} / \mathrm{mL}(7,5 \pm 2,6 \%)(* \mathrm{p}<0.05)$.

\subsubsection{A adição de triptofano recupera a proliferação de linfócitos na presença de MSC}

A IDO, uma enzima citosólica, é responsável por catalisar o metabolismo do aminoácido essencial triptofano e é induzida durante a inflamação por diversos fatores, como por exemplo, PGE2 e INF- $\gamma$ (123). A depleção de triptofano do meio e 
a consequente formação de catabólitos tóxicos contribuem para efeitos imunossupressores, que podem ocorrer pela inibição da proliferação e da ativação de células $\mathrm{T}$, pela indução de células Tregs ou por impedir a formação de células $\mathrm{T}$ de memória $(124,125)$.

A ação da PGE2 foi descartada, pois seu bloqueio pelo uso de IDT potencializou o efeito antiproliferativo das MSCs, entretanto não excluiu a ação desta via. Para verificar se esta via era ativada por alguma outra molécula, adicionamos triptofano ao meio de cultivo, e observamos que a adição de triptofano ao meio de cultivo recupera grande parte da proliferação dos linfócitos CD3 e CD3:CD4 (Figura 16).

A

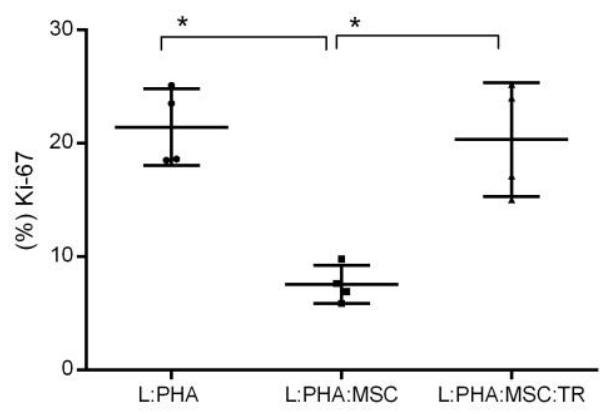

B

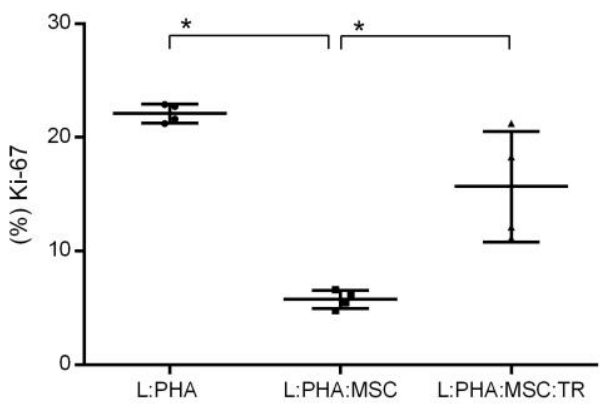

Figura 16 - A adição de triptofano recupera a proliferação de linfócitos T na presença de MSC Linfócitos CD3 quando estimulados com PHA em ausência de MSC (L:PHA) expressaram em média 21,43 $\pm 3,38 \%$ de Ki-67; enquanto em presença de MSC (L:PHA:MSC) esta expressão foi reduzida

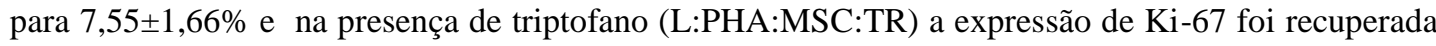
20,33 $\pm 5,03 \%$ (B) Linfócitos CD3:CD4 quando estimulados com PHA em ausência de MSC (L:PHA) expressaram em média 22,10 $\pm 0,83 \%$ de Ki-67; enquanto em presença de MSC (L:PHA:MSC) esta expressão foi reduzida para 5,76 $\pm 0,82 \%$ e na presença de triptofano (L:PHA:MSC:TR) a expressão de Ki-67 foi recuperada $15,68 \pm 4,87 \%$. 


\subsubsection{RESUMO PARTE-II}

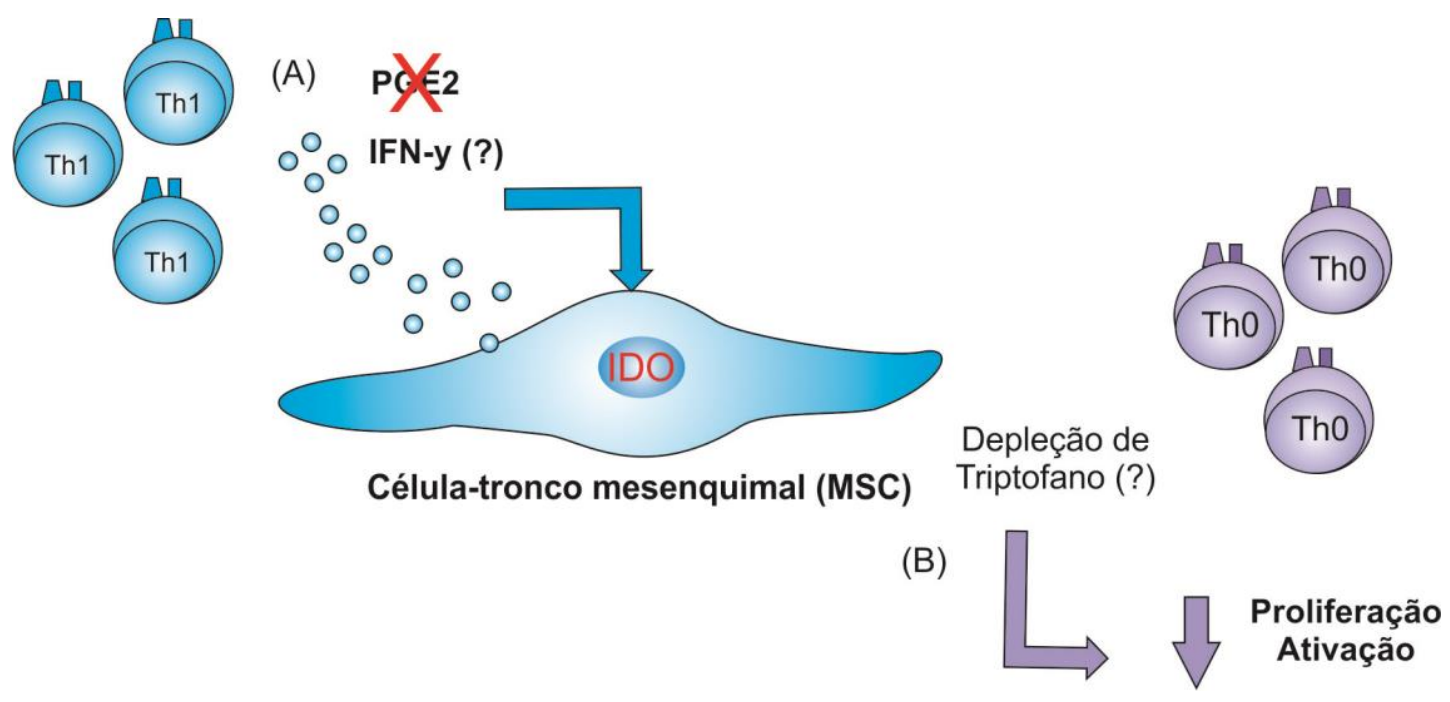

Figura 17 - Esquema sugerido da interação entre linfócitos T e MSC

(A) Moléculas solúveis, como por exemplo, INF- $\gamma$, mas de acordo com nossos resultados não via PGE2, agindo na ativação da enzima IDO citosólica em MSC e (B) Quando ativida a enzima IDO metaboliza o aminoácido triptofano do meio ambiente e leva à redução de proliferação e ativação de linfócitos T.

\subsection{PARTE III - EFEITO DE MSCS NA APOPTOSE DE LINFÓCITOS}

\subsubsection{A presença de MSC reduz apoptose de linfócitos estimulados com PHA}

A redução na proliferação de linfócitos observada na presença de MSC nos levou a investigar se isto não estaria ocorrendo devido ao aumento da apoptose dessas células. Linfócitos CD3 foram estimulados com PHA e co-cultivados ou não com MSC por 24 e 48 horas. As células foram analisadas por citometria de fluxo para a expressão de Anexina-V e Iodeto de Propídeo (PI). Sendo que a Anexina-V se liga a fosfatidil-serinas expostas na membrana celular, indicando apoptose inicial e o PI, uma substância fluorescente que é incapaz de penetrar em células com a membrana celular intacta, quando positivo, indica que a estrutura da membrana plasmática esta porosa. A co-expressão de Anexina-V e PI indica apoptose tardia e/ou necrose. 
Após 24 horas, comparando os linfócitos na ausência ou presença de MSC não observamos diferença significativa para apoptose inicial (Figua 18A). Entretanto, quando comparamos após 48 horas de co-cultivo, observamos redução significativa da percentagem de células em apoptose inicial quando comparado com os linfócitos na ausência de MSC (Figura 18A) e o mesmo foi observado para apoptose tardia/necrose (Figura 18B).
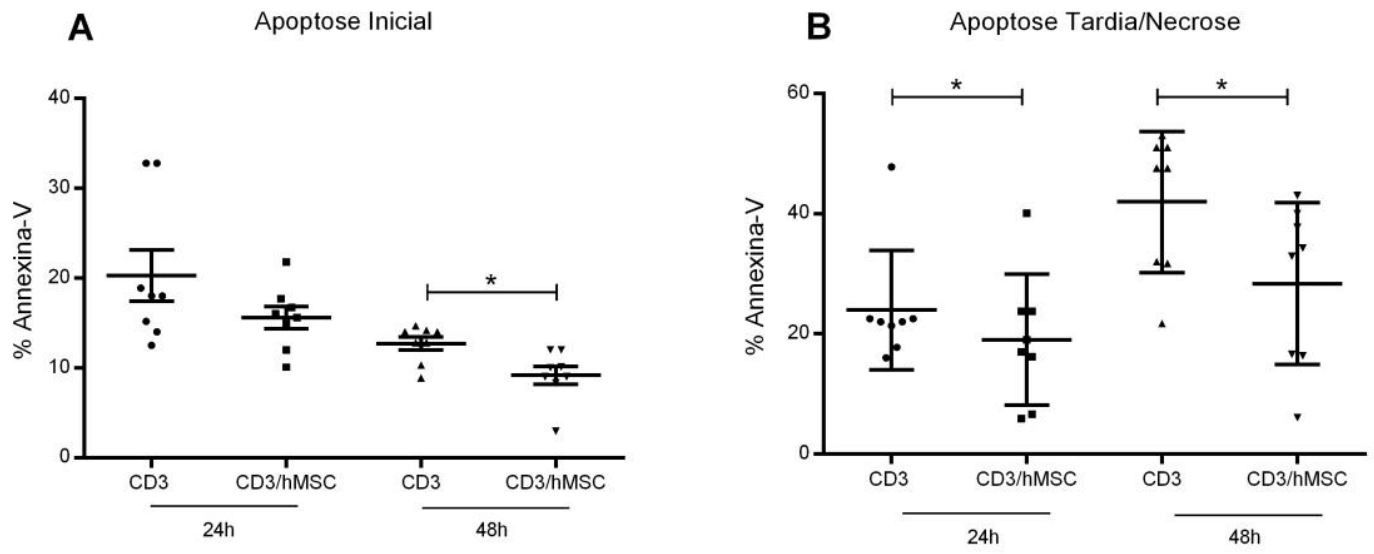

Figura 18 - A presença de MSC reduz apoptose de linfócitos

Apoptose inicial e tardia de linfócitos estimulados com PHA co-cultivados com MSC (CD3/MSCs) ou não (CD3) por 24 e 48 horas (n=8). (A) Observamos redução significativa de apoptose inicial após 48 horas de co-cultivo de linfócitos com MSC $(9,1 \pm 2,8 \%)$ comparado com ausência de MSC $(12,7 \pm 2,0 \%)$. (B) Redução significativa de apoptose tardia e/ou necrose após 48 horas de co-cultivo de linfócitos com MSC $(28,0 \pm 13 \%)$ quando comparado com ausência de MSC $(41,9 \pm 13 \%) * p<0,05$.

\subsubsection{O efeito anti-apoptótico das MSC em linfócitos é parcialmente- dependente de contato}

Para entender se o efeito das MSC na apoptose de linfócitos era dependente do contato entre essas células, utilizamos o inserto com poro 0,22-0,40 $\mu \mathrm{m}$, impedindo o contato físico entre as células. Analisamos por citometria de fluxo os linfócitos controles estimulados com PHA e os co-cultivados com MSC na presença ou não do inserto para a expressão de Anexina-V e PI (Figura 19).

Após 72 horas, observamos redução significativa de apoptose inicial e apoptose tardia/necrose dos linfócitos em co-cultivo na presença ou não da membrana em relação ao controle. Também observamos diferença significativa entre as células cultivadas com MSC e as células cultivadas com MSC e inserto, revelando 
que o efeito anti-apoptótico causado pela MSC nos linfócitos parece ser parcialmente dependente de contato (Figura 20).
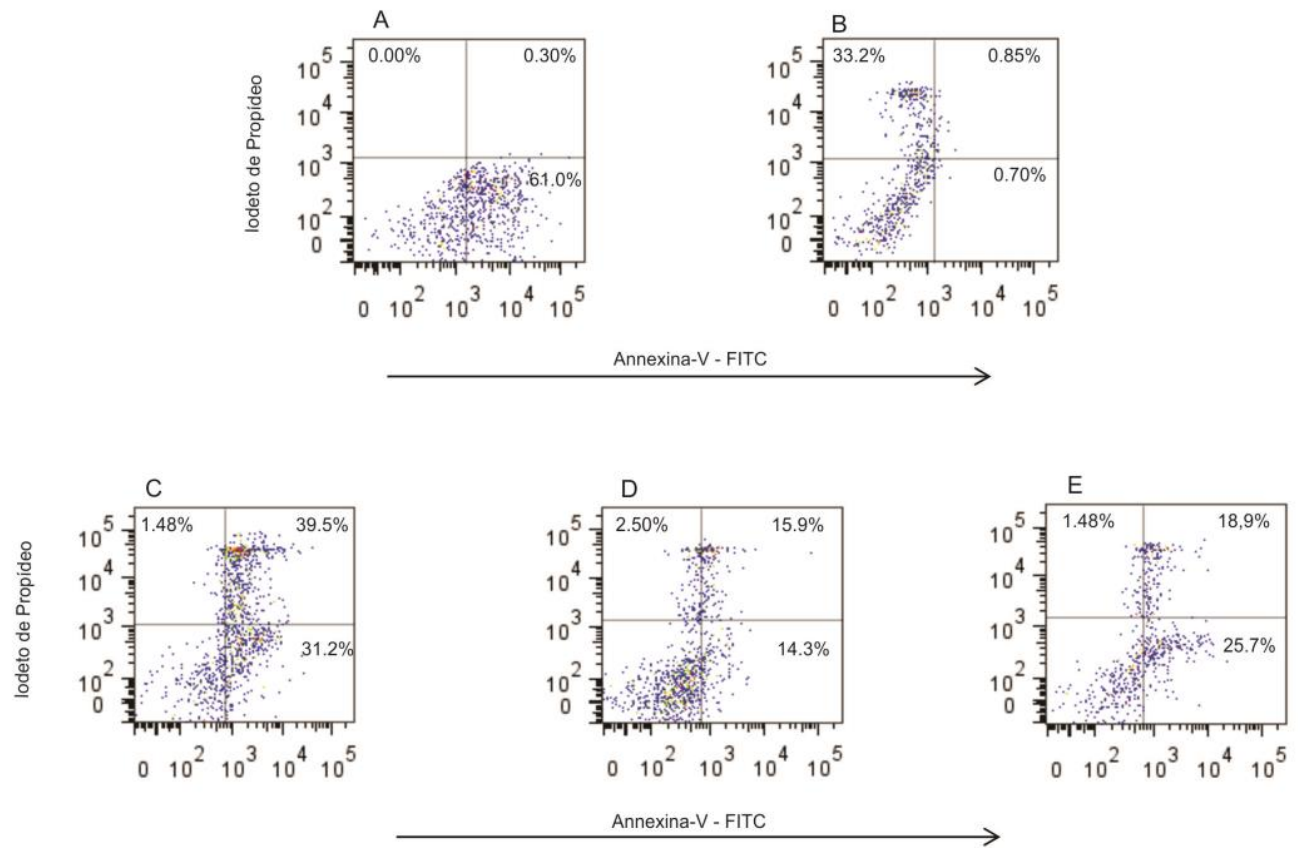

Figura 19 - Estratégia de análise de apoptose

(A) Controle - Linfócitos T marcados apenas com Annexina-V (61\%) (B) Controle - Linfócitos T marcados apenas com Iodeto de propídeo (PI) $(33,2 \%)$ (C) Linfócitos T estimulados com PHA, expressaram Annexina-V (31,2\%) e co-expressaram Annexina-V e PI (39,5\%) (D) Linfócitos estimulados com PHA e co-cultivados com MSC expressaram Annexina-V (14,3\%) e co-expressaram Annexina-V e PI (15,9\%) (E) Linfócitos estimulados com PHA e co-cultivados com MSC separdos por insertos de 0,22-0,40 $\mu \mathrm{M}$ expressaram Annexina-V $(18,9 \%)$ e co-expressaram Annexina-V e PI $(25,7 \%)$. (dado representativo de 8 experimentos) 
A

Apoptose inicial

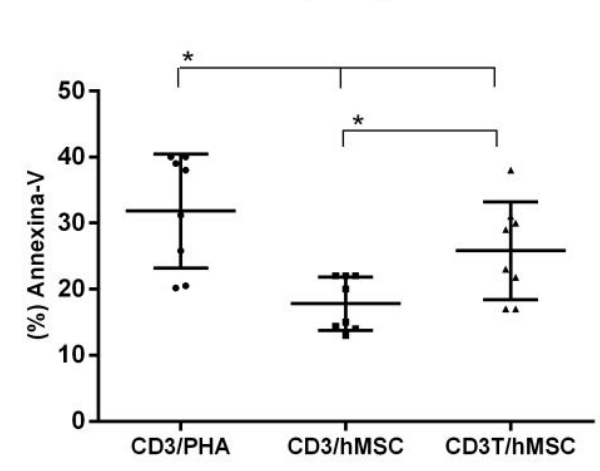

B Apoptose tardia/Necrose (Twell)

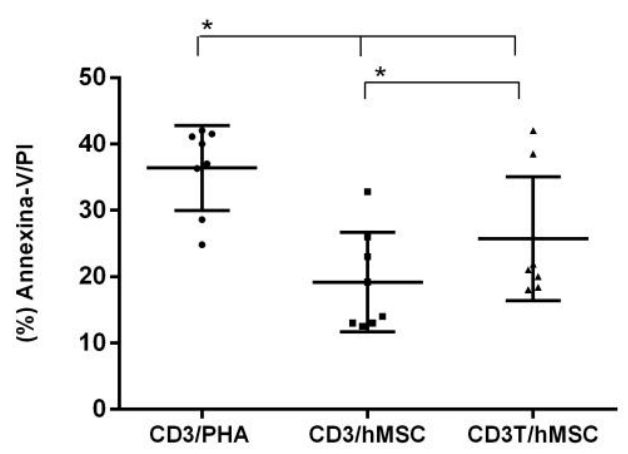

Figura 20 - Efeito de MSC na apoptose de linfócitos é parcialmente contato-dependente Apoptose inicial (A) e tardia/necrose (B) de linfócitos estimulados com PHA, control (CD3/PHA), linfócitos estimulados com PHA e co-cultivados com MSC (CD3/hMSC) e linfócitos estimulados e co-cultivados com MSC na presença de inserto (CD3T/hMSC) por 72 horas $(n=8)$. Em (A) apoptose inicial de linfócitos estimulados com PHA foi cerca de $(31,8,0 \pm 8,60 \%)$, em linfócitos estimulados com MSC $(17,8 \pm 4,86 \%)$, e em linfócitos estimulados com MSC na presença de inserto $(25,0 \pm 7,53 \%)$ (Figura 3A). Em (B) apoptose tardia/necrose dos linfócitos estimulados com PHA foi cerca de $(36,4 \pm 6,4 \%)$,em linfócitos co-cultivados com MSC $(19,18 \pm 7,5 \%)$ e em linfócitos co-cultivados com MSC na presença de inserto $(25,7 \pm 9,34 \%)^{*} \mathrm{p}<0,05$.

\subsubsection{Células de origem mesodérmica reduzem a apoptose de linfócitos}

Para elucidar se o efeito anti-apoptótico observado nos linfócitos era exclusivo da presença de MSC, nós comparamos a apoptose inicial e tardia/necrose de linfócitos estimulados e co-cultivados com MSC e também co-cultivados com linhagem de fibroblastos humanos $(\mathrm{hF})$ e células endoteliais de veia de cordão umbilical humana (HUVEC), após 48 e 72 horas. As células foram analisadas por citometria de fluxo para a expressão de Anexina V e PI.

Após 48 horas de cultura, observamos redução de apoptose inicial de linfócitos co-cultivados com MSC e co-cultivados com hF quando comparados com os co-cultivados com HUVEC ou sem co-cultivo (Figura 21).

Após 48 e 72 horas de cultura, notamos redução significativa de apoptose tardia/necrose de linfócitos co-cultivados com MSC e co-cultivados com hF quando comparamos com linfócitos co-cultivados com HUVEC ou sem co-cultivo (Figura 22). 

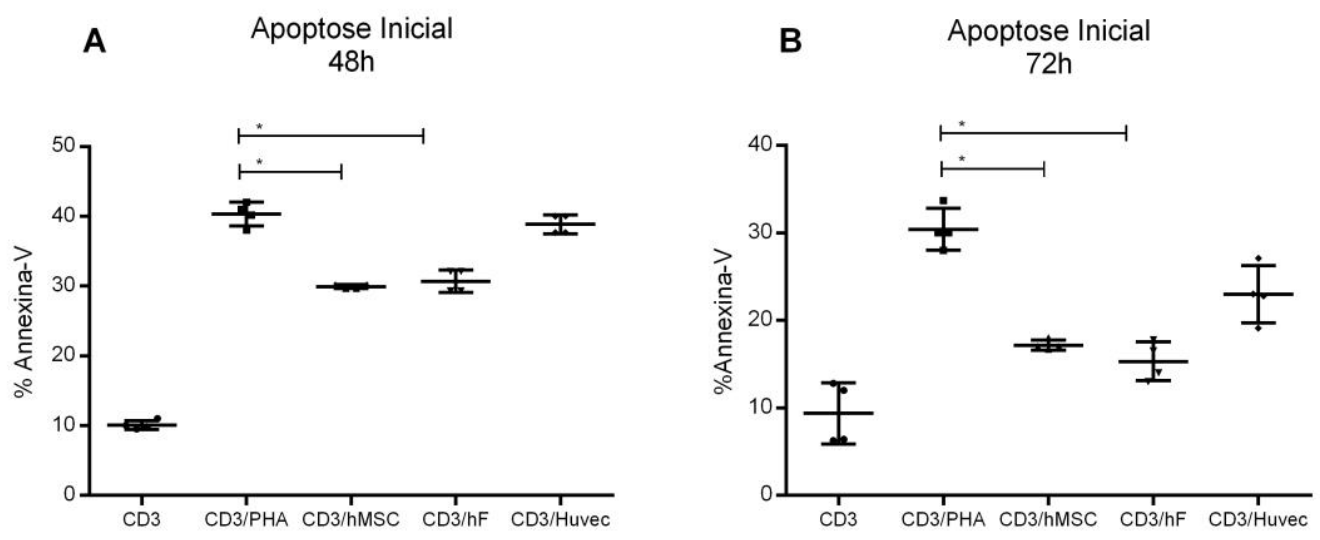

Figura 21 - Efeito anti-apoptótico em linfócitos é dependente de específicas linhagens celulares Apoptose inicial de linfócitos estimulados com PHA (CD3/PHA), estimulados e co-cultivados com MSC (CD3/hMSC), com fibroblastos humanos (CD3/hF) ou com HUVEC (CD3/HUVEC) (n=4). Em (A) apoptose inicial, após 48 horas de cultura, de linfócitos estimulados com PHA $(40,3+1,70 \%)$, cocultivados com MSC $(29,95 \pm 0,29 \%)$, com fibroblastos $(30,70 \pm 1,62 \%)$ e com HUVEC $(38.85 \pm 1.33 \%)$. (B) 72 horas de cultura, apoptose inicial de linfócitos estimulados com PHA $(30,3 \pm 2,38 \%)$, co-cultivados com MSC $(17,18 \pm 0,57 \%)$, com fibroblastos $(15,33 \pm 2,21 \%)$, e HUVEC $(23,00 \pm 3,27 \%) * \mathrm{p}<0,05$.
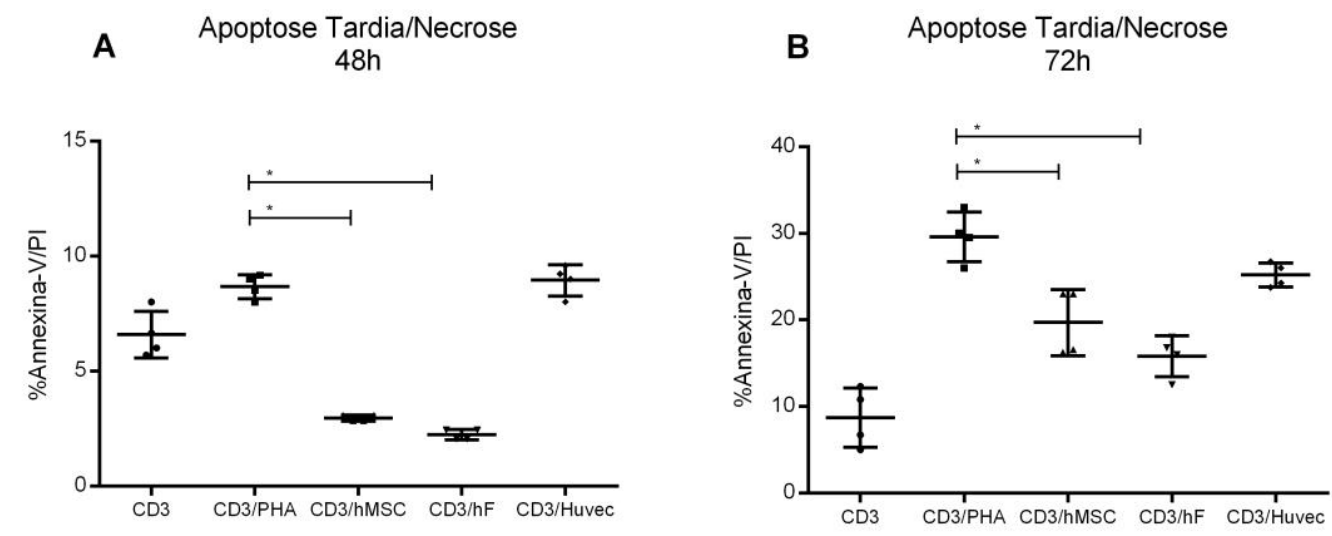

Figura 22 - Efeito anti-apoptótico em linfócitos é dependente de linhagens espécificas

Apoptose tardia/necrose de linfócitos sem estímulo (CD3), estimulados com PHA (CD3/PHA), estimulados e co-cultivados com MSC (CD3/hMSC), com fibroblastos humanos (CD3/hF) e com HUVEC (CD3/HUVEC) ( $n=4)$. Em (A) linfócitos na ausência de co-cultivo $(8,67 \pm 0,53 \%)$, cocultivados com MSC $(2,96 \pm 0,13 \%)$, com fibroblastos $(2,24 \pm 0,23)$ e com HUVEC $(8,96 \pm 0,68 \%)$, após 48 horas de cultura. Em (B), 72 horas de cultura, apoptose tardia/necrose de linfócitos na ausência de co-cultura $(29,63 \pm 2,87 \%)$, co-cultivados na presença de MSC $(19,71 \pm 3,80 \%)$, de fibroblastos $(15,83 \pm 2,36 \%)$ e com HUVEC $(25,20 \pm 1,37 \%) * p<0,05$. 


\subsubsection{MECANISMO DE AÇÃo dAS MSCS EM LINFóCITOS}

Como as MSCs interferem na sobrevivência de linfócitos e diminuem a apoptose dessas células, verificamos a expressão de CD127, cadeia $\alpha$ do receptor de IL-7 (citocina importante para a sobrevivência de linfócitos), em linfócitos estimulados com PHA. Observamos que após 48 horas de cultivo de linfócitos T CD3 com MSCs, maior percentagem de linfócitos expressam CD127 em sua superfície celular (Figura 23).

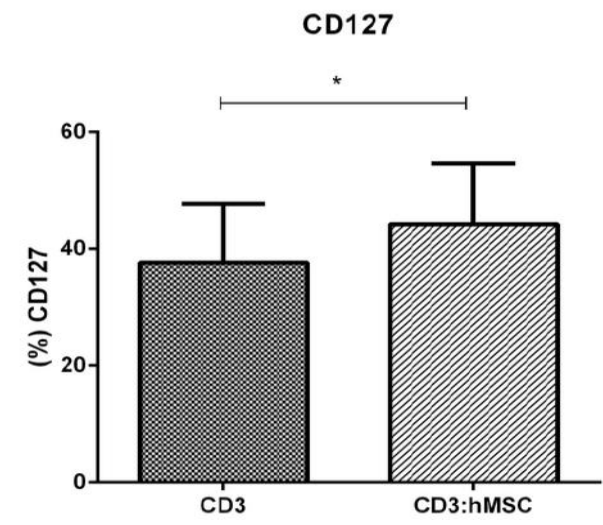

Figura 23 - Presença de MSCs aumenta a expressão de CD127 em linfócitos estimulados com PHA

Linfócitos em cultura por 48 horas (n=5). Aumento da expressão de CD127 em linfócitos estimulados com PHA na presença de MSCs (CD3:hMSC) $(37 \pm 10 \%)$ em relação a linfócitos estimulados com PHA (CD3) $(44 \pm 10 \%) * \mathrm{p}<0,05$.

\subsubsection{Bloqueio de IL-7 nas co-culturas aumenta a apoptose de linfócitos}

Devido ao aumento na expressão de CD127 em linfócitos T quando em cocultivo com MSCs, investigamos se a IL-7 teria algum papel nos efeitos antiapoptóticos observados pela presença de MSCs. A seguir cultivamos linfócitos estimulados com PHA e MSCs em presença de anticorpo policlonal anti-IL-7.

Nós observamos que o bloqueio da IL-7 nas culturas contendo linfócitos e MSCs eleva a apoptose inicial a nível semelhante ao dos linfócitos sem co-cultivo (Figura 24A), enquanto a adição da citocina IL-7 nas culturas de linfócitos estimulados na ausência de MSC reduz a apoptose inicial e tardia/necrose a níveis 
semelhantes aos encontrados em linfócitos na presença de MSCs (Figura 24A e 24B).
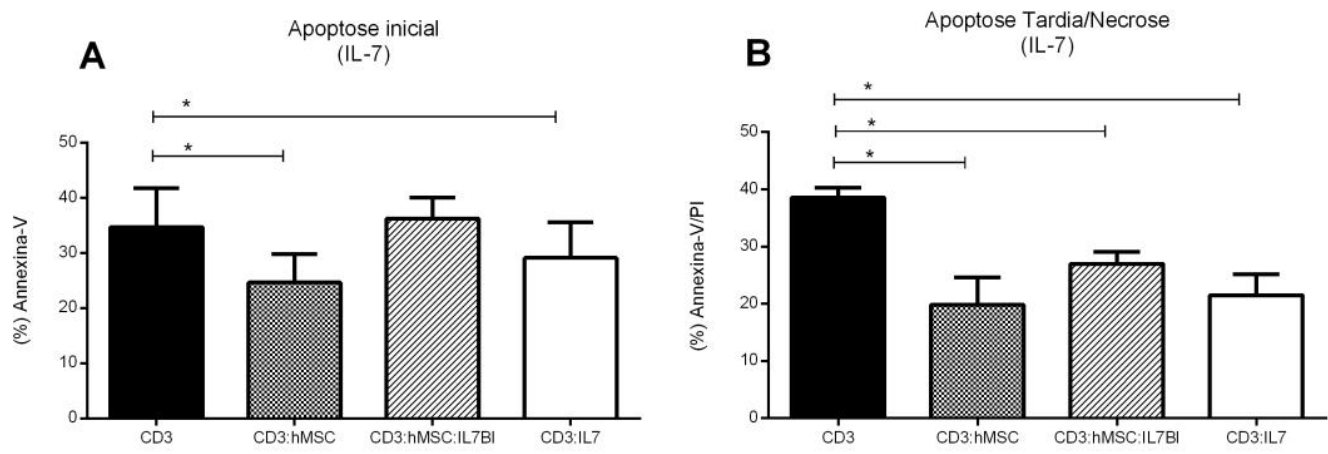

Figura 24 - Efeito da IL-7 em linfócitos estimulados com PHA é similar ao efeito da presença de MSCs e a inibição de IL-7 nas culturas com MSC restaura a apoptose.

Citometria de fluxo de linfócitos estimulados com PHA em cultura por 48 horas sem e compresença de IL-7, e em presença de MSC com e sem antiIL-7(n=4). (A) Apoptose inicial de linfócitos estimulados com PHA (CD3) (34.7 $\pm 7.05 \%)$, na presença de MSCs (CD3:hMSC) $(24.6 \pm 5.11 \%)$, na presença de MSCs e anti-IL-7 (CD3:hMSC:IL-7Bl) (36.27士3.8\%) e de linfócitos estimulados na presença de IL-7 (CD3:IL-7) (29.12+6.4). (B) Apoptose tardia/necrose de linfócitos estimulados com PHA (CD3) $(38.55+1.76 \%)$, na presença de MSCs (CD3:hMSC) $(19.85+4.72 \%)$, na presença de MSCs e anti-IL-7 (CD3:hMSC:IL-7Bl) $(26.97+2.12 \%)$ e de linfócitos estimulados na presença de IL7 (CD:3IL-7) $(21.52+3.65 \%) * \mathrm{p}<0,05$

\subsubsection{MSC produzem a citocina IL-7}

Para confirmar que a citocina IL-7 esta envolvida nos efeitos anti-apoptóticos observados na presença de MSC, nosso próximo passo foi investigar se MSC presentes nas co-culturas produziam a citocina IL-7.

Observamos que as MSC produzem a citocina IL-7 em culturas in vitro e essa produção se mantém na presença de linfócitos estimulados (Figura 25). 

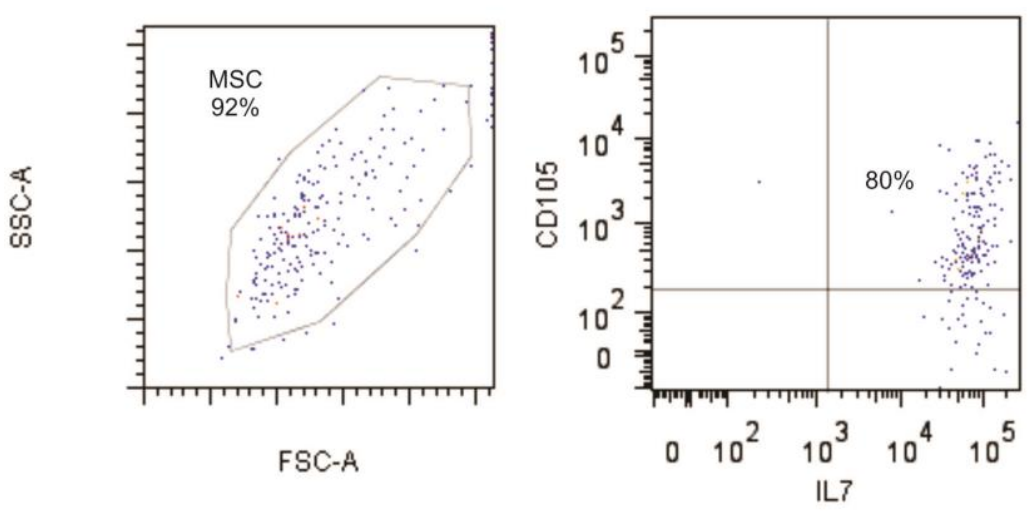

Figura 25 - Estratégia de seleção de população de MSC positiva para IL-7.

Citometria de fluxo intracelular de MSC na presença de linfócitos estimulados com PHA em cultura por 24 horas. Estratégia de seleção da população de MSC por tamanho (FSC) e granulosidade (SSC) e estratégia de seleção de população duplo-positiva para CD105 e IL-7 (80\%) (dado representativo de 4 experimentos).

\subsubsection{RESUMO PARTE-III}

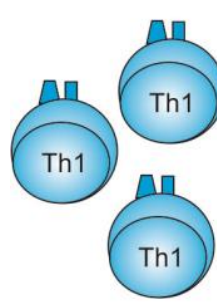

(A) $P C \in 2$

$\circ 0^{\circ} \mathrm{IFN}-\mathrm{y}$ (?)

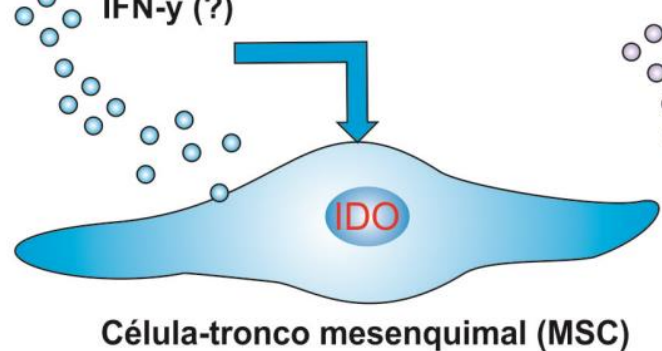

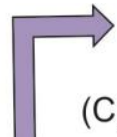

(C)

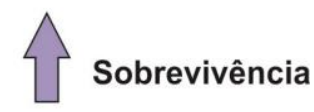

(B)
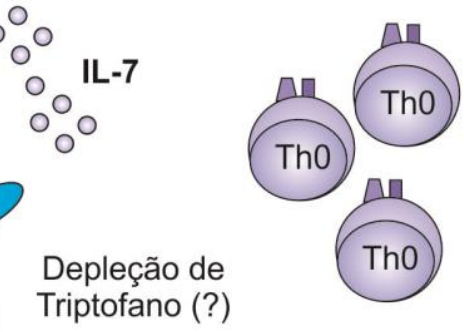

Proliferação

Ativação

Figura 26 - Esquema sugerido da interação entre linfócitos T e MSC

(C) De acordo com os experimentos realizados, pudemos concluir que as MSCs produzem IL-7, e que esta citocina produzida por MSC interfere na sobrevivência e apoptose de linfócitos. 


\subsection{Parte IV - EFeIto das MSCs EM Linfócitos Th17}

A DECH aguda é uma resposta imune desenvolvida principalmente por linfócitos $\mathrm{T}$ padrão Th1 e Th17 (73). Envolve resposta mediada por células $\mathrm{T}$ aloreativas do doador contra os tecidos do receptor e fatores solúveis (63) (81). A seguir investigamos se a presença de MSC altera de alguma maneira a resposta do tipo Th1 e Th17.

Para isso, diferenciamos linfócitos Th1 e Th17 in vitro a partir de linfócitos T virgens. Os linfócitos foram obtidos de sangue periférico, seguidos pelaseleção indireta de células T virgens CD45RA (Figura 27).
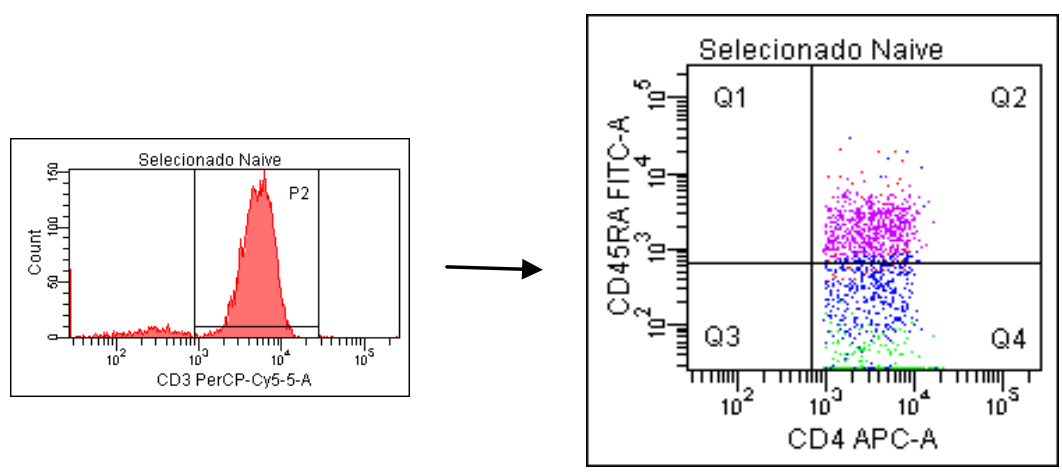

Figura 27 - Estratégia de avaliação dos linfócitos T vigens após seleção indireta com coluna de seleção

Seleção em CD3 (pureza >90\%), e em seguida a população de linfócitos CD45RA (80\%) (dado representativo de 3 experimentos).

\subsubsection{Caracterização da população de linfócitos Th17}

A população de linfócitos $\mathrm{T}$ virgens foi estimulada com microesferas (antiCD3 e anti-CD28) e citocinas (Figura 28) e cultivados por 5 dias. Ao final do tempo de cultivo, as moléculas de migração CCR5 e CCR6, estavam altamente expressas, enquanto a expressão de CD45RA diminui e de CD45RO aumenta. O fator de transcrição ROR $\gamma$ t (Th17) estava expresso em praticamente 90\% das células com estímulo para Th17 (Figura 29) indicando que o estímulo com microesferas e 
citocinas favorece a diferenciação de células $\mathrm{T}$ virgens em células Th17, quando comparados com linfócitos estimulados com PHA ou sem estímulo.

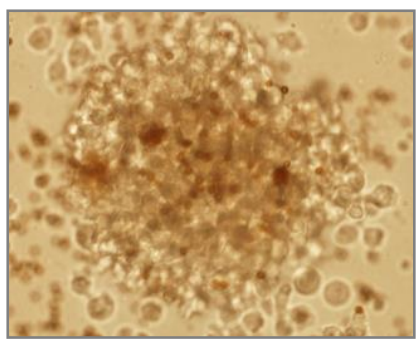

Figura 28 - Imagem de um aglomerado de linfócitos após estímulo com microesferas antiCD3/CD28 e citocinas
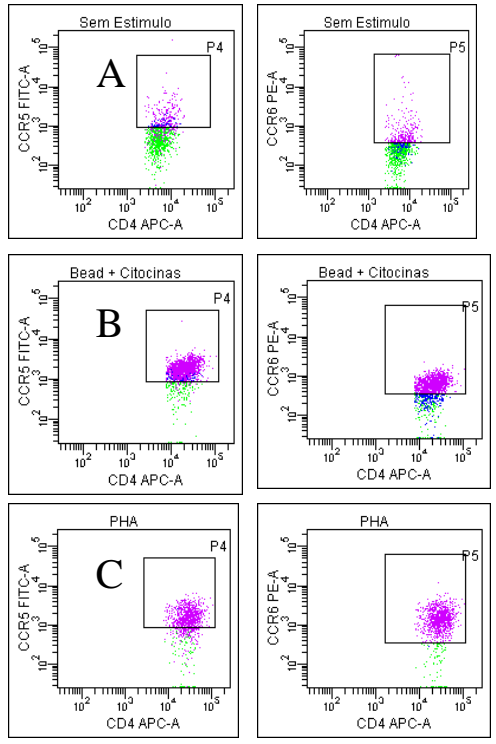
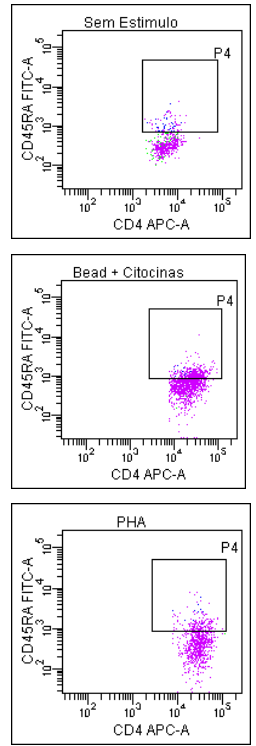
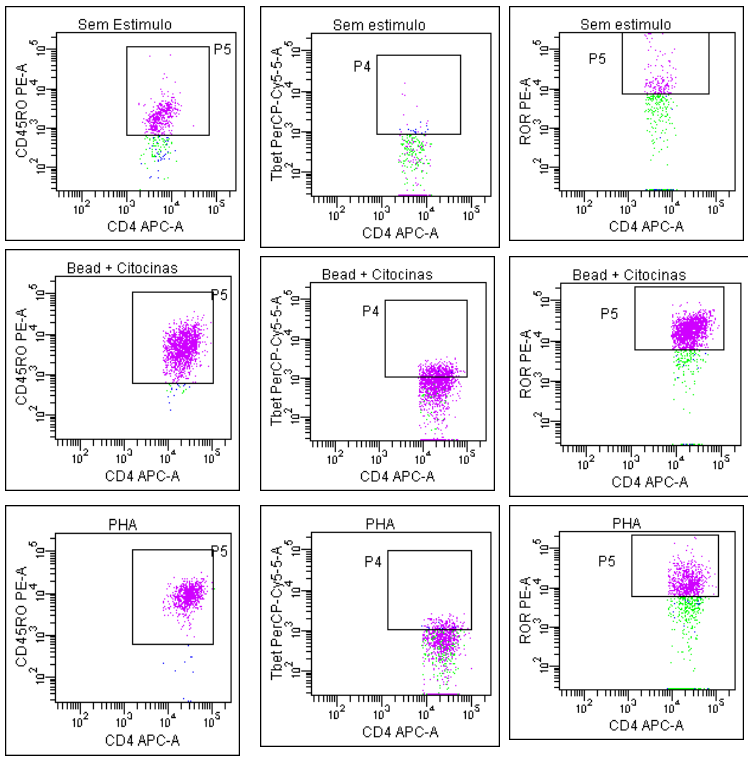

Figura 29 - Estratégia de análise de população de linfócitos Th17

Linfócitos cultivados por 10 dias. Expressão de CCR5, CCR6, CD45RA, CD45RO, Tbet e ROR $\gamma \mathrm{t}$ pelas células mantidas sem estímulo (A), com estímulos de microesferas e citocinas (B) e com estímulo com PHA (C). (dado representativo de 3 experimentos).

\subsubsection{MSC interferem na produção de IFN- $\gamma$ por linfócitos T}

Para estudar o efeito de MSCs em linfócitos virgens em diferenciação para o perfil Th17, cultivamos por 5 dias na presença ou ausência de MSCs (Figura 30) e analisamos por citometria de fluxo a produção de citocinas após estímulo com PMA, ionomicina e befeldrina A. Observamos que os linfócitos diferenciaram mais para 
Th1 que para Th17, devido a grande produção de IFN-y detectadas nestes linfócitos. Entretanto pudemos observar que a presença das MSCs nas culturas de linfócitos em diferenciação reduziu a produção intracelular de INF- $\gamma$ e de IL-17A destes (Figura $31)$.
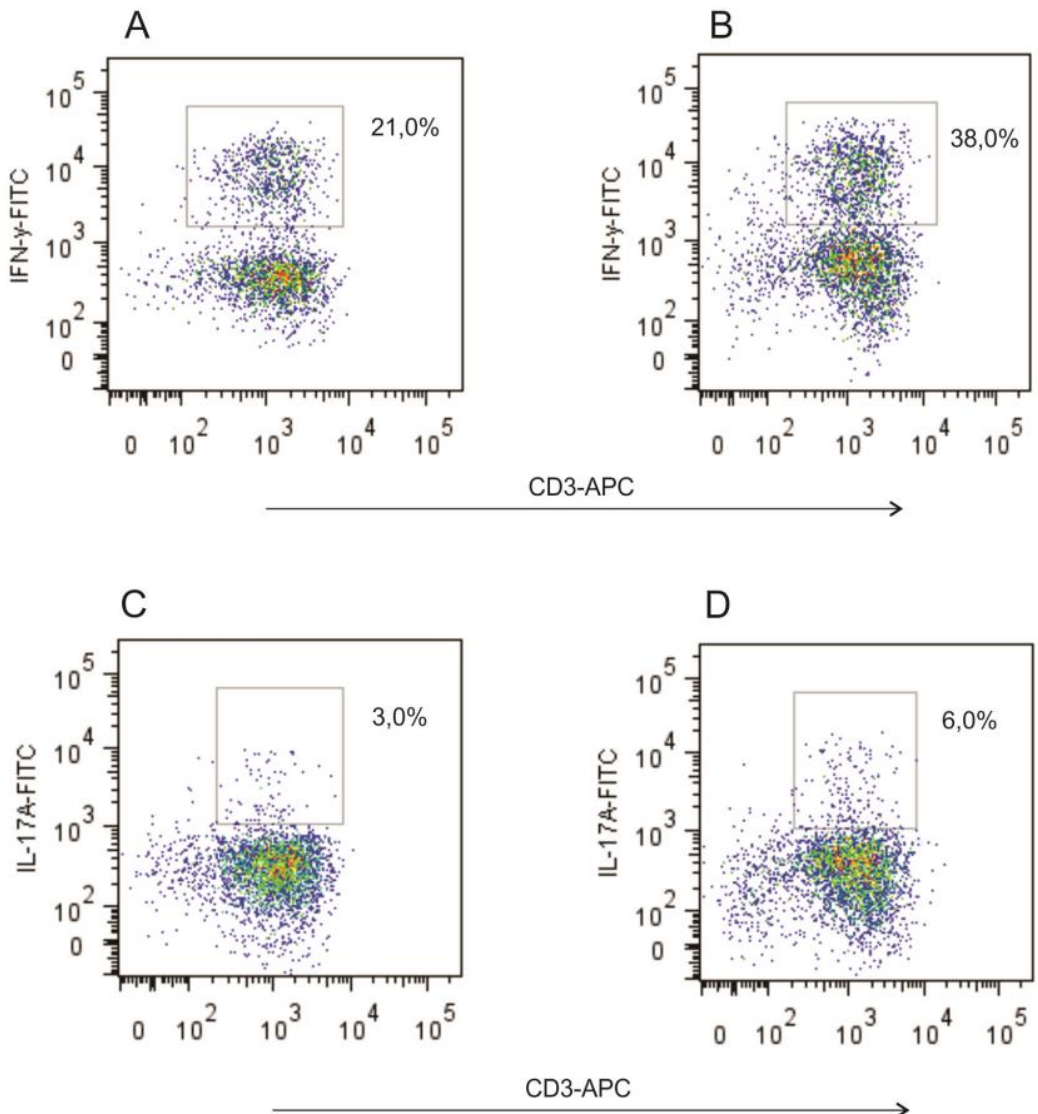

Figura 30 - Estratégia de gate para verificação da produção de IFN-y e IL-17A por linfócitos T Citometria de fluxo de linfócitos em diferenciação para Th17 e previamente estimulados com PMA e Ionomicina. (A) e (B) Expressão de INF- $\gamma$ de linfócitos Th17 na presença $(21,0 \%)$ ou ausência de MSCs $(38,0 \%)$ respectivamente. (C) e (D) Expressão de IL-17A intracelular por linfócitos Th17 na presença $(3,0 \%)$ ou ausência $(6,0 \%)$ de $\mathrm{MSCs}$ respectivamente (dado representativo de 3 experimentos). 

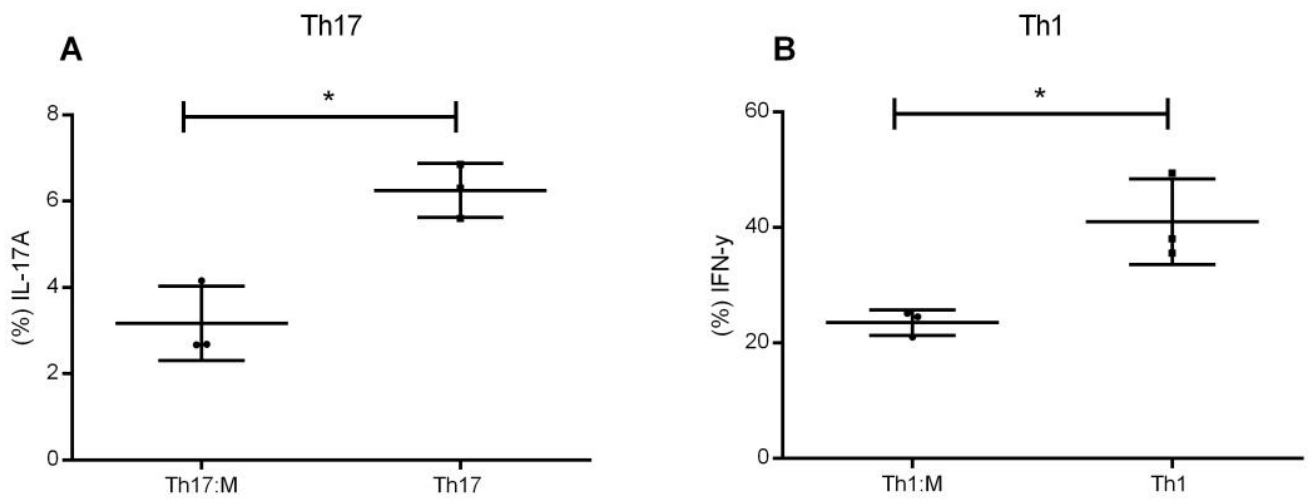

Figura 31 - MSC reduzem a produção de IFN-y e IL-17A de linfócitos T virgens estimulados a diferenciar em Th17

Células em diferenciação para Th17 sem anti INF-y (n=3 (A) Apenas 6,2 $\pm 0,62 \%$ das células em diferenciação foram capazes de produzir IL-17A, em presença de MSC este número foi reduzido para $3,17 \pm 0,8 \%$. (B) Houve grande produção de INF-y pelos linfócitos em diferenciação para Th17 sugerindo um desvio para Th1, cerca de 40,9 $\pm 7,4 \%$ dos linfócitos produziram IFN-y, enquanto em presença de MSC apenas 23,2 $\pm 2,2 \%$ dos linfócitos produziram IFN-y.

\subsubsection{MSC reduzem a produção de IL-17A por linfócitos}

Como observamos que houve grande produção de IFN- $\gamma$ por essa população de células, a seguir adicionamos anti-IFN- $\gamma$ aos linfócitos em diferenciação. Observamos que maiores quantidades de IL-17A foram produzidas e as MSCs também foram capazes de modular essa produção (Figura 32).

Notamos que na presença de anti-IFN- $\gamma$ as células apresentam quantidade intracelular maior de citocina IL-17A e a presença de MSCs reduz a quantidade dessa citocina (Figura 33). 

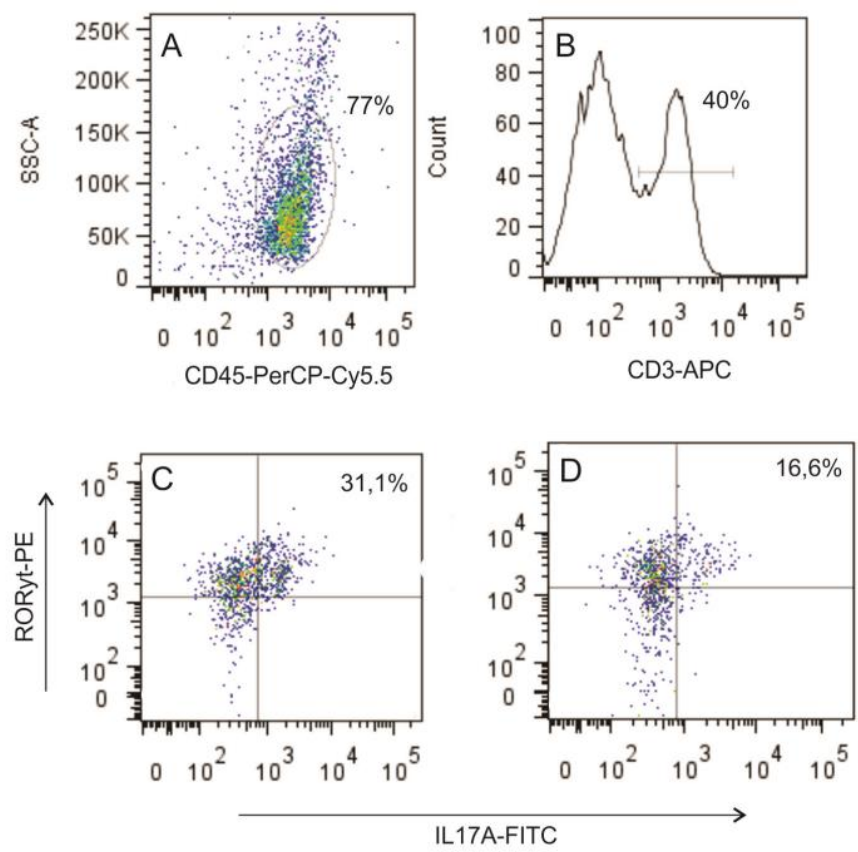

Figura 32 - Estratégia de gate para verificar a produção de citocinas por linfócitos em diferenciação para Th17 na presença de anti-IFN- $\gamma$

Citometria de fluxo de linfócitos em diferenciação para Th17 na presença de anti-IFN- $\gamma$ e previamente estimulados com PMA e Ionomicina. (A) Estratégia de seleção de linfócitos em CD45 por tamanho $(77,4 \%)$ (B) Estratégia de seleção em CD3 (40\%). (C) e (D) Estratégia de população duplo positiva para expressão de IL-17A e ROR- $\gamma$ t de linfócitos em diferenciação para Th17 na ausência $(31,1 \%)$ ou presença $(16,6 \%)$ de MSCs, respectivamente (dado representativo de 3 experimentos).

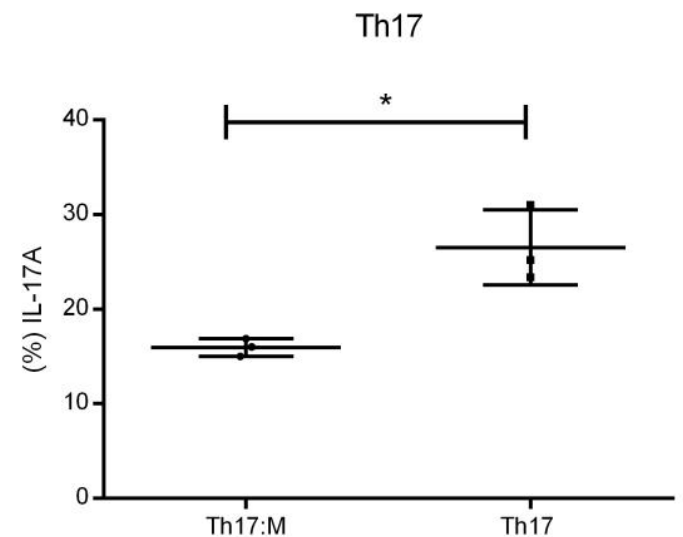

Figura 33 - MSC interfere na produção de IL-17A por linfócitos em diferenciação para Th17 na presença de anti-IFN- $\gamma$

Citometria de fluxo de linfócitos em diferenciação para Th17 na presença de anti-IFN- $\gamma(\mathrm{n}=3)$. Observamos que $26,5 \pm 3,9 \%$ dos linfócitos expressavam o fator de transcrição RORyt e produziam IL17A, na presença de MSC esta percentagem foi reduzida para $15,96 \pm 0.95 \%$. 


\subsubsection{MSC reduzem a produção de IL-17A, mas não alteram porcentagem número de células $T$ reguladoras nas culturas}

A presença de MSCs nas culturas reduz a produção de citocinas inflamatórias (IFN- $\gamma$ e IL-17A) por linfócitos T. Então postulamos que a presença de MSCs poderia favorecer a diferenciação de linfócitos $\mathrm{T}$ virgens em linfócitos $\mathrm{T}$ reguladores (Treg). Para verificar esta possibilidade avaliamos o número de Tregs (Figura 34) em culturas na presença e ausência de MSCs com ou sem adição de anti-IFN- $\gamma$.

Não observamos diferença significativa entre o número de Tregs na ausência e presença de MSCs (Figura 35), mesmo com a adição de anti-IFN- $\gamma$ (Figura 35B). 

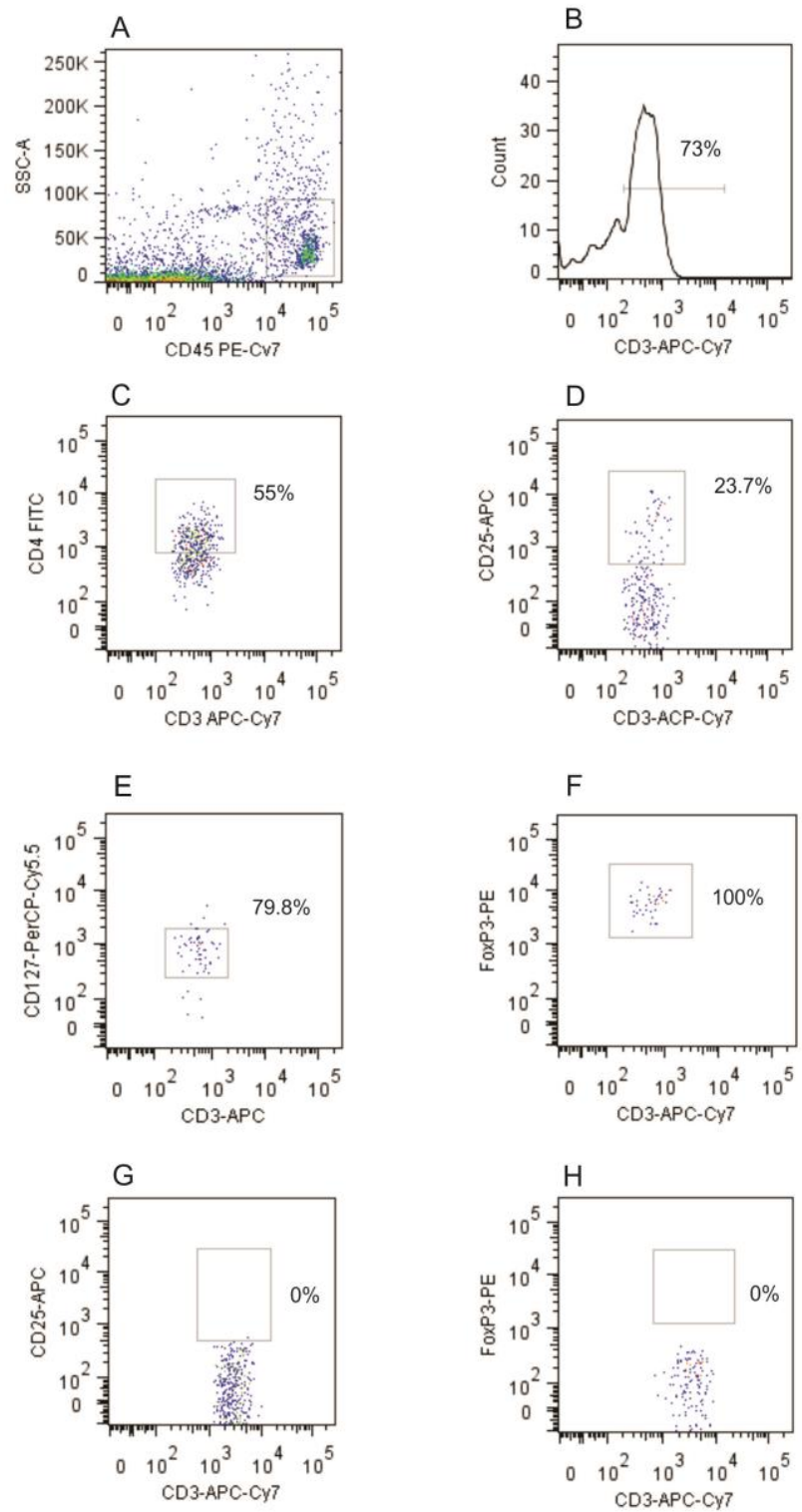

Figura 34 - Estratégia de análise de células $\mathbf{T}$ reguladoras

(A) Seleção da população de linfócitos no gráfico SSC vs CD45, (B) seleção das células positivas para CD3 (73\%). (C) Seleção de células positivas para CD3:CD4 (55\%), (D) Dentro da população CD3:CD4, seleção de células CD25 high (23,7\%), (E) Denro da população CD3, CD4, CD25 seleção de células positivas para CD127 low (79,8\%\%) (F) Dentro da população CD3, CD4, CD25, CD127, seleção da população FoxP3 (100\%), (G) Controle-FMO para a população CD25 $(0 \%)$ e $(\mathrm{H})$ Controle-FMO para a população FoxP3 $(0 \%)$. 


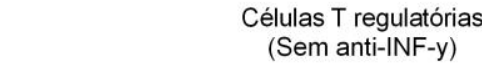

A

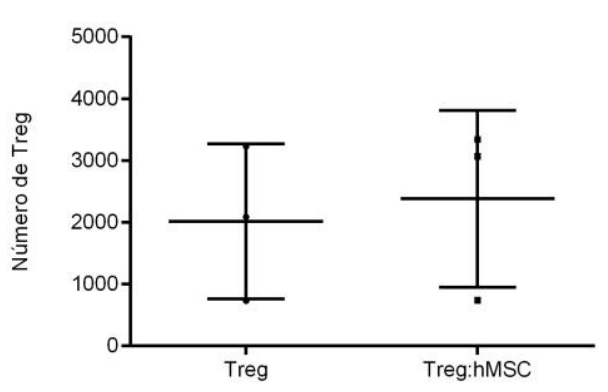

Células $T$ regulatórias

(Com anti-INF-y)

B

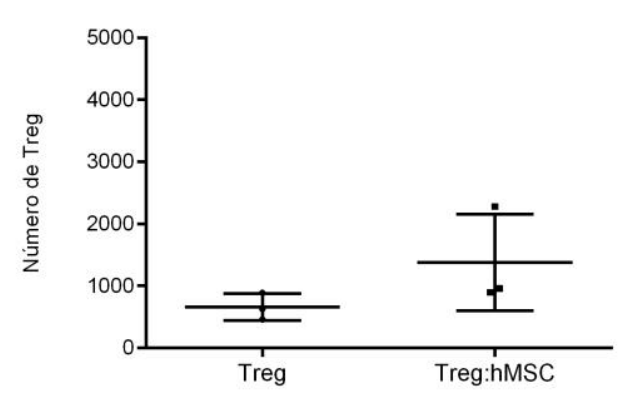

Figura 35 - A presença de MSCs não altera o número de células T reguladoras em culturas para diferenciação para Th17

Número absoluto de Tregs em cultura para diferenciação em Th17 (n=3). (A) Número de células Tregs na ausência de anti-IFN-y (Treg) na ausência de MSC (2216 \pm 1251$)$ e na presença (Treg:hMSC) (2383 \pm 1429$)$ (B) Número de Treg na presença de anti-IFNy (Treg) $(660 \pm 215)$ e na presença de MSC (Treg:hMSC)(1380 \pm 780$)$.

\subsubsection{RESUMO PARTE IV}
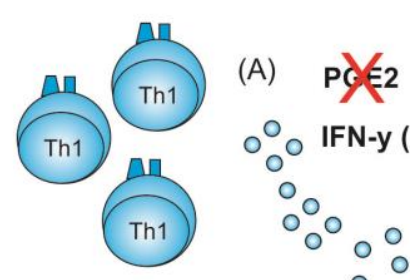

${ }_{0}^{\circ} \mathrm{O}$ IFN-y (?)
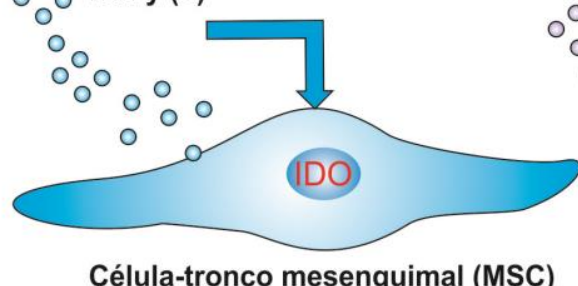

Célula-tronco mesenquimal (MSC)

(D)

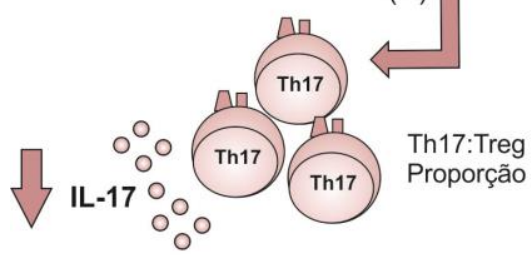

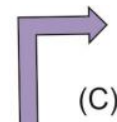

(C)
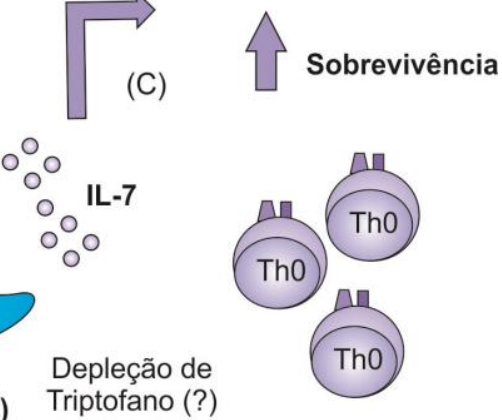

(B)

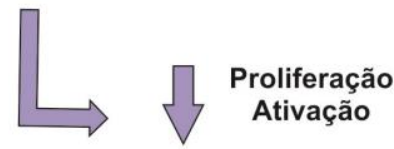

Figura 36 - Esquema sugerido da interação entre linfócitos T e MSC

(D) A presença de MSC em culturas de linfócitos Th17 reduz sua produção de IL-17A, favorecendo a ação supressora de linfócitos Tregs. Dessa forma o balanço entre as respostas inflamatória (Th17) e reguladora (Tregs) é alterado. 


\section{DISCUSSÃO}

A DECH aguda é uma resposta imunológica mediada por linfócitos $\mathrm{T}$ efetores, principalmente dos tipos Th1 e Th17, por ser uma resposta altamente inflamatória, a busca por mecanismos que sejam capazes de modular essa resposta é de grande interesse.

$\mathrm{Na}$ primeira fase deste estudo, nós demonstramos que células-tronco mesenquimais humanas (MSCs) podem ser obtidas para utilização em pesquisa cientifica a partir da lavagem de filtros de coletas de medula óssea, reutilizáveis ou descartáveis (121).

O modelo de simulação da doença do enxerto contra hospedeiro (DECH), foi de cultura de linfócitos e células dendríticas alogênicas, considerando que a percentagem de células T no sangue periférico capazes de reconhecer alo-antígenos e responder a eles, in vivo e in vitro, varia entre 1 e $10 \%$ dependendo do grau de compatibilidade entre os indivíduos (24).

Na segunda etapa do estudo, nós demonstramos que a presença de MSCs em culturas contendo linfócitos ativados com PHA regula de maneira negativa a expressão de moléculas de superfície relacionadas com a ativação de linfócitos, CD25 e CD69, em concordância com dados previamente publicados (126, 127).

De mesmo modo, quando comparamos a proliferação e a apoptose de linfócitos ativados com PHA ou com células dendríticas alogênicas, em co-cultivo ou não com MSCs, observamos efeitos reguladores e/ou supressores que essas células são capazes de exercer (128).

Entretanto, os mecanismos pelos quais essa interação ocorre não são totalmente claros, nós mostramos que linfócitos ativados cultivados em contato direto ou separados por um inserto com as MSCs também apresentam redução da proliferaçãoindicando que esse efeito in dependentes de contato e que provavelmente ocorre via fatores solúveis, conforme Figuras 10.

Alguns grupos mostraram que a inibição da proliferação de linfócitos estimulados com PHA acontece de maneira parcialmente dependente do contato com as MSCs (101), outros, por outro lado, mostraram que a inibição da proliferação de linfócitos estimulados via CD3 acontece independente do contato (109) e nesse 
mesmo contexto, outros grupos demonstram a capacidade das MSCs alterarem o fenótipo de outras células, como macrófagos também acontece de maneira independente de contato (129).

Quando comparamos os efeitos das MSCs sobre linfócitos estimulados com outras células de diferentes origens embrionárias, mesodérmica e ectodérmica, nós notamos que o efeito observado na apoptose de linfócitos não acontece com células células endoteliais (origem ectodérmica), por outro lado, pudemos observar também redução na apoptose de linfócitos co-cultivados com fibroblastos, que apresentam mesma origem mesodérmica das MSCs e provavelmente respondem de maneira semelhante a um dado estímulo imunológico (Figuras 19 e 20).

Uma vez que a DECH aguda é considerada uma resposta imune dirigida principalmente por células T auxiliares do tipo 1 (Th1) e Th17 (73) envolvendo resposta mediada por células $\mathrm{T}$ aloreativas do doador contra tecidos do receptor e mediados por fatores secretados (63). Nosso estudo demonstra de forma importante que durante a diferenciação de linfócitos Th1 e Th17 in vitro, a presença de MSCs ocorre redução da capacidade de produção de IFN- $\gamma$ e IL-17A pelos linfócitos, independentemente das citocinas inflamatórias presentes nas co-culturas.

Este estudo não detectou aumento de células $\mathrm{T}$ reguladoras nessas culturas, entretanto, demonstrou a redução na percentagem de células capazes de produzir INF- $\gamma$ e IL-17A, o que sugere a alteração da razão entre as células efetoras antiinflamatórias e pró-inflamatórias. Esta mudança da razão é bastante importante sugerindo para as MSC um papel preventivo na terapia da DECH (130).

Outro grupo que demonstrou redução de linfócitos Th17 na presença de MSCs, também demonstrou aumento do fenótipo de células T reguladoras. (131) Entretanto este estudo utilizou citometria de fluxo para quantificar as células $\mathrm{T}$ reguladoras em seu perfil fenotípico completo $\mathrm{CD} 3 / \mathrm{CD} 4 / \mathrm{CD} 25^{\text {hi }} / \mathrm{CD} 127^{\text {low }} /$ FoxP3 enquanto o outro grupo apenas quantificou a expressão de FoxP3 por RNA, o que pode explicar os resultados discrepantes.

A adição de indometacina (IDT), uma droga anti-inflamatório não esteroidal que inibi as vias da ciclooxigenases 1 e 2, nas co-culturas revelou que os efeitos antiproliferativos e anti-apoptóticos das MSCs observados nos linfócitos ocorrem de uma maneira independente de prostaglandina E2. 
Nossos resultados contrapõem mecanismos anteriormente descritos por Ramusson et al, o qual descreveu que MSC tratadas com IDT, via monócitos, inibem o efeito anti-proliferativo nos linfócitos (132). Nossas culturas foram depletadas de monócitos, isso nos permite sugerir que os efeitos antiproliferativos e antiapoptóticos observados pela presença de MSC são independentes de prostaglandina.

Nemeth et al, do mesmo modo que o outro grupo mostrou o efeito da prostaglandina na resposta anti-proliferativa causada pelas MSCs em linfócitos, na sepsis humana via reprogramação de macrófagos. Nossos dados divergentes podem ser explicados devido a ausência de macrófagos em nossas culturas $(112,132)$.

Um grande número de estudos indica que IDO tem efeito antiproliferativo e antiapoptótico nessas condições. Entretanto estes estudos elegem a prostaglandina como responsável pela ativação da IDO, nosso grupo e outros estudos acreditam que não a prostaglandina, mas outra molécula, como o IFN- $\gamma$ pode estar associado a esses efeitos $(133,134)$.

A IDO age pela depleção do aminoácido triptofano do meio de cultura, que leva a apoptose celular, isso não foi observado nos nossos experimentos, concordando com outros estudos (135-137). O mecanismo pelo qual ocorre a inibição de apoptose ainda permanece desconhecido.

Conforme mostramos que o papel na proliferação e apoptose de linfócitos acontece de uma maneira independente de contato e independente de prostaglandina, sugerimos uma potencial correlação entre a citocina IL-7 e o efeito anti-apoptótico das MSCs, uma cez que observamos aumento da expressão do receptor de IL-7 (CD127) na membrana de linfócitos (Figura 21). Ainda, quando bloqueamos a ação da citocina IL-7 nas co-culturas, observamos aumento de apoptose nos linfócitos (Figura 22).

Citocinas como a IL-7, membro da família da IL-2, uma molécula envolvida nas vias intrínseca e extrínseca da apoptose, a qual aumenta os níveis de proteínas antiapoptóticas ou inibe proteínas pró-apoptóticas, como por exemplo BID, BAD ou BAX. A citocina IL-7 é descrita como uma citocina produzida por vários tipos célulares, como células T, células NK, monócitos e células estromais (138-140).

De fato, nós encontramos que o bloqueio de IL-7 em co-culturas contendo linfócitos e MSCs aumenta significantemente a apoptose inicial dos linfócitos, ao 
passo que, a adição desta citocina as culturas controles evita a apoptose inicial e tardia. Esse efeito é similar ao que encontramos na presença de MSCs (Figura 22). Por outro lado, quando adicionamos IL-7 a culturas de linfócitos sem MSCs nós não observamos aumento da proliferação (dados não mostrados). Suportando nossos achados, a IL-7 tem sido descrita como citocina que mantem a viabilidade celular pela repressão de fatores de morte e/ou pela ativação de fatores de sobrevivência.

Mostramos também que as MSC em cultura contendo linfócitos estimulados produzem a citocina IL-7, que parece estar envolvida com a sobrevivência de linfócitos (Figura 23). Enquanto a IL-7 não interfere na proliferação de linfócitos T, o efeito antiproliferativo observado em linfócitos co-cultivados com MSCs pode ter ocorrido devido ativação de IDO ou por algum outro mecanismo como, por exemplo, citocinas IL-6, IL-10 e/ou TGF- $\beta(139,141)$.

\section{CONCLUSÃO}

$\checkmark$ Concluímos que MSCs obtidas pela lavagem de filtros de coletas de MO, descartáveis ou não, são factíveis para utilização em experimentos.

$\checkmark$ As MSCs apresentam efeito antiproliferativo e anti-apoptótico em linfócitos estimulados com PHA ou estimulados com DCs, de uma maneira independente de contato entre as células.

$\checkmark$ A presença de MSCs e de fibroblasto, ambas as células de origem mesodérmica, e não a HUVEC, de origem endodérmica, reduzem a apoptose inicial e tardia/necrose de linfócitos ativados.

$\checkmark$ Efeito antiproliferativo e anti-apoptótico parece ser independente de prostaglandina.

$\checkmark$ A adição de triptofano recupera a proliferação de linfócitos.

$\checkmark$ MSC produzem IL-7 em culturas contendo linfócitos ativados.

$\checkmark$ A presença de MSCs durante a diferenciação de célula $\mathrm{T}$ virgem para o padrão Th17 reduz a capacidade de produção e secreção de IL-17A por linfócitos ativados com PHA e não observamos aumento de células Treg nesse cenário.

$\checkmark$ A presença de MSCs em cultura com linfócitos aumenta a expressão da cadeia $\alpha$ do receptor de IL-7 (CD127) em linfócitos estimulados com PHA. 
Nossos dados permitiram importantes resultados preliminares sobre as vias envolvidas na modulação pelas MSC em linfócitos, sugerimos que sinais de sobrevivência dirigidos por IL-7 desempenham importante papel no processo de apoptose destas células. Entretanto, ainda permanece desconhecido como a IL-7 age na sobrevivência das células T CD3 nas nossas culturas e se outras moléculas também participam desse processo.

Dessa forma, o trabalho permitiu a compreensão de alguns possíveis mecanismos pelos quais as MSC podem atuar na inibição da ativação de linfócitos alorreativos e/ou produção de citocinas. Mecanismos importantes para a prevenção de DECH, onde a resposta inflamatória exacerbada de linfócitos é a causa dano tecidual, sendo de grande interesse inibir, modular ou controlar esse tipo de resposta e também conhecer as vias e mecanismos pelos quais acontece. 


\title{
9 ANEXOS
}

\subsection{PARECER - CerTIFICAdo de APRESEnTAÇÃo PARA APRECIAÇÃo ÉTICA}

\author{
HOSPITAL ISRAELITA ALBERT \\ EINSTEIN-SP
}

\section{PROJETO DE PESQUISA}

Título: Estudo do efeito imunomodulatório das células tronco-mesenquimais.

Área Temática:

Versão: 1

CAAE: $\quad 06592712.4 .0000 .0071$

Pesquisador: Luciana Cavalheiro Marti

Instituição: Hospital Israelita Albert Einstein-SP

\section{PARECER CONSUBSTANCIADO DO CEP}

\begin{tabular}{lc}
\hline Número do Parecer: & 113.596 \\
Data da Relatoria: & $02 / 10 / 2012$
\end{tabular}

$02 / 10 / 2012$

Apresentação do Projeto:

Na primeira etapa do projeto vamos co-cultivar células linfomononucleares de doadores saudáveis com células mesenquimais. As células linfomononucleares serão separadas por gradiente de densidade (Ficoll-Paque), e serão pré-estimuladas com:

a) Células estimuladas com mitógeno (controle positivo), que é um estímulo não específico que induz proliferação e resposta inespecífica nos linfócitos.

b) Células estimuladas com células alogênicas ( $3^{a}$ parte), que é um estímulo alogenêico que vai induzir uma resposta similar ao $\mathrm{DECH}$ de reconhecimento alogenêico.

c) Células sem estímulo (controle negativo), que vai representar a mudança basal que ocorre da interação linfócitos/mesenquimais na ausência de estímulo ou doença.

Para análise de linfócitos por citometria de fluxo pré e pós co-cultivo com as células mesenquimais não será necessária a separação física das células, sendo a análise de sub-população (linfocitária) feita através da seleção (Gate) de células CD3 positivas.

Para verificar se há alterações na expressão gênica dos fatores de transcrição destes linfócitos (ROR ¿t,

ROR ¿ ¿ ¿FoxP3, T-bet e Gata3) ou ativação de vias de sinalização através da razão entre proteínas fosforiladas e não fosforiladas (ERK1, ERK2, LAT e SLP-76) destes linfócitos será necessário a separação física destas células, que deverá ser feita utilizando beads magnéticas ligadas a anticorpo monoclonal anti-CD3.

Parte II

$\mathrm{Na}$ segunda etapa do projeto vamos separar células CD3/CD4/CD45RA de sangue periférico de adultos normais. As células serão separadas por gradiente de densidade (Ficoll-Paque), e em seguida separadas utilizando um Kit de separação indireta de células T virgens da Miltenyi Biotec (Alemanha).

Estas células Th0, sem padrão definido de resposta com fenótipo CD3/CD4/CD45RA, serão cultivadas com citocinas para derivação do padrão de Th17, após 7 dias de cultivo serão analisadas por citometria de fluxo para o fenótipo Th17 e para o fenótipo Treg, como também será extraído RNA e proteína.

Então as células na sua maioria Th17 serão co-cultivadas com células mesenquimais, após co-cultivo estas células serão analisadas por citometria

de fluxo. Para extração de RNA e determinação se ocorre alteração de expressão nos fatores de transcrição (ROR ¿t, ROR ¿¿¿FoxP3, T-bet e Gata3) ou ativação de vias de sinalização através da razão entre proteínas fosforiladas e não fosforiladas (ex: ERK1, ERK2, LAT e SLP-76).

Será necessário a separação física destas células, que deverá ser feita utilizando beads magnéticas ligadas a anticorpo monoclonal anti-CD4.

\section{Objetivo da Pesquisa:}

Primário: Co-cultivar células mononucleares, bem como células Th17 com células mesenquimais e verificar se ocorre mudança no padrão de resposta nos linfócitos, bem como, alteração na expressão

Endereço: Av. Albert Einstein 627 - 2ss

Bairro: Morumbi

UF: SP Município: SAOPAULO

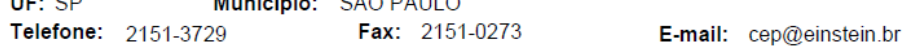




\section{HOSPITAL ISRAELITA ALBERT EINSTEIN-SP}

gênica e ativação de vias de sinalização

Secundários:

1- Co-cultivar células linfomononucleares pré-estimuladas com mitógeno (controle positivo), células alogênicas (teste) e sem estímulo (controle negativo) derivadas de doadores saudáveis com células mesenquimais. Verificar mudança no padrão fenotípico destes linfócitos. - Verificar se há alterações na expressão gênica para fatores de transcrição destes linfócitos. - Verificar se há alterações na ativação de vias de sinalização através da razão de proteínas fosforiladas por proteínas não fosforiladas destes linfócitos. Mais detalhes na estratégia experimental (Parte I).

2- Co-cultivar linfócitos derivados de células virgens de sangue de cordão umbilical que apresentem um padrão de resposta na sua maioria Th17 com células mesenquimais. - Verificar se há mudança no padrão fenotípico destes linfócitos. - Verificar se há alterações na expressão gênica para fatores de transcrição destes linfócitos. Verificar se há alterações na ativação de vias de sinalização através da razão de proteínas fosforiladas por proteínas não fosforiladas destes linfócitos.

\section{Avaliação dos Riscos e Benefícios:}

Riscos: Não há

Benefícios: Desenvolvimento de novo conhecimento.

Comentários e Considerações sobre a Pesquisa:

Projeto de pesquisa e emenda da mesma já aprovados pelo CEP Einstein em setembro de 2010 e junho de 2011, respectivamente. Em anexo estão os pareceres emitidos.

Considerações sobre os Termos de apresentação obrigatória:

A solicitação de isenção de aplicação de termo de consentimento livre e esclarecido foi aceito.

Recomendações:

Não há.

Conclusões ou Pendências e Lista de Inadequações:

Aprovar.

Situação do Parecer:

Aprovado

Necessita Apreciação da CONEP:

Não

\section{Considerações Finais a critério do CEP:}

Acatado pelo colegiado o parecer do relator.

Endereço: Av. Albert Einstein 627 - 2ss

Bairro: Morumbi

UF: SP Município: SAO PAULO

Telefone: 2151-3729 Fax: 2151-0273 E-mail: cep@einstein.br 
HOSPITAL ISRAELITA ALBERT EINSTEIN-SP

SAO PAULO, 02 de Outubro de 2012

Assinado por:

José Pinus

(Coordenador) 


\title{
9.2 TERMO DE CIÊNCIA DO COMITÊ DE ÉTICA EM PESQUISA
}

\author{
Iiliti: \\ MEDICINA \\ COMITÊ DE ÉTICA EM PESQUISA
}

\section{CIÊNCIA}

O Comitê de Ética em Pesquisa da Faculdade de Medicina da Universidade de São Paulo, em 17.01.13 tomou ciência do Projeto $n^{\circ}$ oo1/13 intitulado "Estudo do efeito imunomodulatório das células troncomesenquimais", vinculado à pós-graduação do Departamento de Clínica Médica, Disciplina de Imunologia Clínica e Alergia, que não envolverá atividade prática e/ou experimental no âmbito da Faculdade de Medicina ou Instituto do Câncer do Estado de São Paulo e que conta com prévia aprovação do Comitê de Ética em Pesquisa do Hospital Albert Einstein, onde o projeto será executado.

Pesquisador(a) Responsável: Luciana Cavalheiro Marti

Pesquisador(a) Executante : Marilia Normanton

CEP-FMUSP, 17 de janeiro de 2013.

$$
\begin{aligned}
& \text { pllasunem. } \\
& \text { Prof. Dr.Roger Chammas } \\
& \text { Coordenador } \\
& \text { Comitê de Ética em Pesquisa }
\end{aligned}
$$




\subsection{Artigos PUblicados}

\subsection{1 "ISOLAMENTO \\ E CARACTERIZAÇÃO \\ DE \\ CÉLULAS-TRONCO \\ MESENQUIMAIS \\ DE FILTROS REUTILIZÁVEIS \\ E DESCARTÁVEIS \\ DE MEDULA ÓSSEA"}

\section{ORIGINAL ARTICLE}

\section{Isolation and characterization of mesenchymal stem cells obtained from reusable and disposable bone marrow collection filters}

Isolamento e caracterização de células-tronco mesenquimais de filtros reutilizáveis e descartáveis de medula óssea

Glaziane Cordeiro de Deus ${ }^{1}$, Marilia Normanton ${ }^{2}$, Nelson Hamerschlak ${ }^{3}$, Andrea Tiemi Kondo ${ }^{4}$, Andreza Alice Feitosa Ribeiro, Anna Carla Goldberg ${ }^{2}$, Luciana Cavalheiro Marti ${ }^{2}$

\section{ABSTRACT}

Objective: To compare human mesenchymal stem cells obtained from reusable and disposable filters and to characterize them according to the criteria of the International Society of Cellular Therapy. Methods: Human mesenchymal stem cells were isolated from bone marrow collection reusable set s and compared with those obtained from disposable sets by washing the filters with cell culture media. The isolated cells were characterized according to the criteria of the International Society of Cellular Therapy using flow cytometry. differentiation in vitro, and cytochemistry techniques. Results: Samples were obtained from disposable $(n=3)$ and from reusable collection sets $(n=3)$. All samples obtained from bone marrow disposable sets successfully produced mesenchymal stem cells. All bone marrow derived mesenchymal stem cells were characterized and fulfilled the criteria established by International Society of Cellular Therapy. Conclusion: This study showed that mesenchymal stem cells can also be obtained from reusable collection sets (which are still used in several centers around the world) to be employed in research as an alternative and ethical source.

Keywords: Mesenchymal stem cells; Bone marrow; Filtration: Disposable equipment; Recycling

\section{RESUMO}

Objetiva Comparar as células-tronco mesenquimais humanas obtidas de filtros de coleta reutilizóveis àquelas coletadas em filtros descartôveis e caracterizálas utilizando os critérios da intemational Society for Cellutar Therapy. Métodos: Foram isoladas célulastronco mesenquimais humanas de kits de coleta de medula ósse reutilizáveis e descartâveis, pela lavagem dos filtros com meio de cultura. As células isoladas foram caracterizadas de acordo com os critérios estabelecidos pela intemetional Society for Cellitiar Therapy. por meio das técnicas de citometria de fluxo, diferenciação in vituo e citoquímica. Resultados: As amostras foram obtidas de filtro descartável $(n=3)$ e reutilizável $(n=3)$. Todas as amostras obtidas de filtros descart ́́veis prodıriram células-tronco mesenquimais, todas as célulastronco mesenquimais humanas derivedas de medula óssea preencheram os critérios estabelecidos pela irtemational Society for Cellutar Therapy. Conclusäo: Este estudo mostrou que as células-tronco mesenquimais também podem ser obtidas de kits de coleta reutilizáveis (que permanecem em uso em vấrios centros, no mundo inteirol, para serem empregadas em pesquisa como uma fonte alt ernativa e ética.

Descritores: Células-tronco mesenquimais; Medula óssea; Filtração; Equipamentos descartâveis; Reciclagem

\section{INTRODUCTION}

The best characterized source for adult stem cells is the bone marrow, which contains a het erogeneous population of cells, including hematopoietic progenitor and st em cells. 
In addition to these cell types, the bone marrow also contains a subset of non-hematopoietic st em cells with multilineage potential. These stem cells are called "marrow stromal stem cells" or "human mesenchymal stem cells" (hMSC)(1).

The hMSCS are primitive cells originated from the mesodermal germ layer, and they have been described as giving rise to connective tissue, skeletal muscle, and vascular system cells(29).

In 2006, the Mesenchymal and Tissue Stem Cell Committee of the International Society for Cellular Therapy (ISCT) proposed minimal criteria to characterize hMSCs(4).

The hMSCs must be plastic-adherent when maintained in standar $d$ culture conditions. In addition, they must express CD29, CD73, CD90, and CD105, and lack expression of CD34, CD45, CD14, and human leukocyte antigen HLA-DR on the surface. Furthermore they must also have the pot ential to differentiate into osteoblasts, adipocytes, and chondroblasts in vitro Presently, most studies characterize bone-marrowderived hMSCs according to these criteria. However, many unanswered questions remain such as the true nature and identity of hMSCs, including their location, origin, and multipotential capacity. Isolation of hMSC has been reported from sever al tissues, such as bone marrow, adipose tissue, liver, muscle, amniotic fluid, placenta, umbilical cord blood, and dental pulp ${ }^{(5.7)}$.

Since bone marrow derived hMSCs are the most commonly used cells in clinical trials, these cells probably will be the usual source in further studies. In addition, they ar $e$ an important control for defining other possible hMSC sources.

HMSCS have ben efficiently recovered, unaffected by the gender of the donor, from bone marrow aspirates of healthy individuals, and also of patients suffering from serious diseases and injuries. However, hMSCS are an extrem ely rare cell type, accounting for less than $0.1 \%$ of nucleated cells in bone marrow aspirates ${ }^{(0-10)}$.

For clinical applications, the bone marrow is aspirated from the posterior iliac crest and collected in disposable or reusable collection sets cont aining culture media supplemented with anticoagulant.

For economical reasons, bone marrow collection reusable sets are widely employed in several centers around the world. During this procedure, the bone marrow graft is filt ered and transferred to a transport bag, mainly to remove clogs and bone particles from the material that will be infused into the patient. The material remaining in the filter is usually discarded.

Under standard protocols, hMSCs are isolated from filtered bone marrow samples. Inter estingly, it has been proposed that in bone marrow aspirates there is also the formation of hematons, which are a stromal-web tightly packed with hematopoietic progenitor cells and differentiated post-mitotic cells. Since thes e clusters are more than $50 \mathrm{~mm}$ in diam eter, they are probably removed by disposable filters, whose pore sizes range from 500 to $200 \mu \mathrm{m}$. Reusable filters have smaller pore sizes $(250 \text { or } 150, u \mathrm{~m})^{(11)}$. Dvor akova et al., Capelli et al., Sundin et al., and others reported successful isolation of hMSCs from bone marrow collection disposables ets, but no one has report ed this from reusable filters ${ }^{(22-14)}$.

In this study, we isolated and characterized hMSCS obtained from bone marrow collection filters of both disposable and reusable sets. Since collecting bone marrow from health volunteers for research is a complex issue due to the morbidity of the procedure (and several centers still use reusable sets for collecting bone marrow grafts), this study present the reusable sets as an alternative cell source for clinical and research purposes.

\section{OBJECTIVE}

To compare hMSCs obtained from reusable and disposable sets and to char acterize them according to the criteria of the ISCT

\section{METHODS}

\section{Cell havesting and isolation}

The procedure to obtain cells from the filter was approved by the Hospital Israelita Albert Einstein Ethical Committee (HIAE), process number 10/1,412. After harvesting for transplant purposes and filtering bone marrow cells from health volunteers, the filter was washed with $20 \mathrm{~mL}$ of cell culture medium DMEM-LG (Gibco ${ }^{\oplus}$, Carlsbad, CA) to recover the cells trapped inside the filter together with blood clogs and small bone fragments (Figures 1 and 2). The disposable

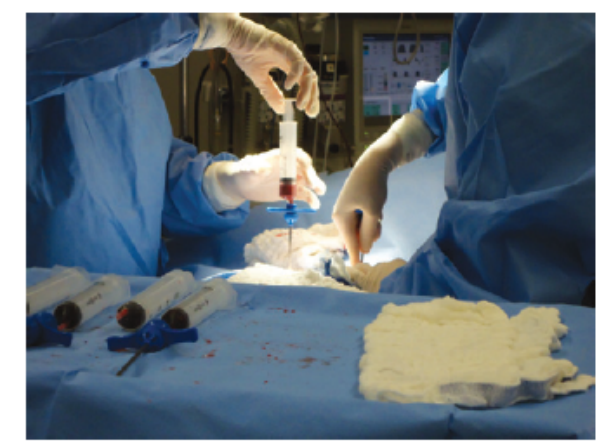

Figure 1. Bone marrav aspiration 


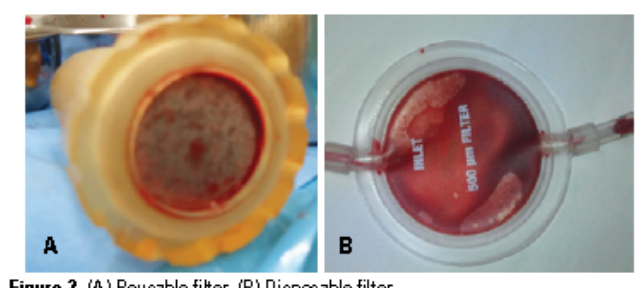

Figure 2. (A) Reusable filter. (B) Disposable filter

filter used presented two types of pores sized 200 and $500 \mu \mathrm{m}$ (Fenwal, Lake Zurich, $\amalg$ ), and the reusable one presented two pore sizes of 150 and $250 \mu \mathrm{m}$. The $150-\mu \mathrm{m}$ filter was employed in this study (University of Washington, Seattle, WA).

\section{Isolation of hMSC}

The bone marrow sample obtained after filtering was diluted (1:3) with phosphate-buffer saline (PBS), and then transferred to a $50 \mathrm{~mL}$ conical tube containing $20 \mathrm{~mL}$ of Ficoll/Hypaque (GE Healthcare) and centrifuged for 30 minutes at $500 \mathrm{~g}, 22^{\circ} \mathrm{C}$. After centrifugation the cells were transferred to another tube and centrifuged again for 5 minutes at $500 \mathrm{~g}$, $22^{\circ} \mathrm{C}$, the supernatant was discarded and cells were resuspended with DMEM-LG (Gibco ${ }^{\circ}$, Carlsbad, CA) supplemented with $10 \%$ FBS (Gibco ${ }^{\circ}$, Carlsbad, CA) in order to achieve a concentration of $1 \times 10^{5} \mathrm{cells} / \mathrm{mL}$. Next, the cells were cultivated in $25 \mathrm{~cm}^{2}$ flasks maintained in humidified $5 \% \mathrm{CO}_{2}$ incubators at $37^{\circ} \mathrm{C}$ to favor the attachment of the hMSC to the flask bottom.

\section{Culture and cell differentiation}

The medium was changed for the first time after 48 hours of culture, and every other day after that. The flask containing the cells was verified by optical microscopy every day in order to confirm the adherence of hMSC colonies. After the establishment of hMSC cultures on the fourth passage, the cells differ entiated in adipocytes, osteoblasts, and chondrocytes.

Adipogenesis was induced by addition of an adipogenic medium, comprised by Alpha-MEM (Gibco ${ }^{\infty}$, Carlsbad, CA) supplement ed with $10 \%$ FBS (Gibco", Carlsbad, CA), $1, \mu m$ dexamethasone (Sigma, St Louis, MO), $100 \mu \mathrm{g} / \mathrm{mL}$ 3-Isobutyl-1-methylxanthine IBMX (Sigma, St Louis, MO), $10 \mu \mathrm{kg} / \mathrm{mL}$ insulin (Sigma, St Louis, MO), and $100 \mu \mathrm{M}$ indomethacin (Sigma, St Louis, MO). The adipogenic medium was changed every other day for 3 weeks.
Osteoblast differentiation was induced by addition of an osteogenic medium, comprised of Alpha-MEM (Gibco ${ }^{\circ}$, Carlsbad, CA) supplemented with $10 \%$ FBS (Gibco ${ }^{\circ}$, Carlsbad, CA), $1 \mu \mathrm{m}$ dexamethasone (Sigma, St Louis, MO), $2 \mu \mathrm{k} / \mathrm{mL}$ ascorbic acid (Sigma, St Louis, $\mathrm{MO}$ ), and $10 \mu \mathrm{m}$ beta-glycerophosphate (Sigma, St Louis, MO). The osteogenic medium was changed every other day for 3 weeks.

Chondrocyte differentiation was induced by addition of chondrogenic medium, that was Alpha-MEM (Gibco ${ }^{\circ}$, Carlsbad, CA) supplemented with $10 \%$ FBS (Gibco ${ }^{\star}$, Carlsbad, CA), 1 $\mu \mathrm{m}$ dexamethasone (Sigma, St Louis, MO), 2ug/mL ascorbic acid (Sigma, St Louis, MO), 6,25ug/mL insulin (Sigma, St Louis, MO), and 10ng/mL TGF-beta (Sigma, St Louis, MO). Chondrogenic medium was changed every other day for 3 weeks.

\section{Immunohistochemical staining methods}

Oil Red O

Adipogenic differentiation was demonstrated by staining lipid droplets aft er 3 weeks in culture. The cells wer e fixed in $4 \%$ paraformaldehyde for 30 minutes, washed, dehydrated in $60 \%$ isopropanol for 2 to 5 minutes, and stained with $0.5 \%$ Oil Red O (O-0625; Sigma) in $100 \%$ isopropanol previously dilut ed in water.

\section{Alizarin Red}

Osteogenic differentiation was evaluated by Alizarin Red staining after 3 weeks in culture. For Alizarin Red, the cells were fixed in $4 \%$ paraformaldehyde for 30 minutes, washed with distilled water, stained with Alizarin Red ( $2 \mathrm{~g}$ in $100 \mathrm{~mL}$ of distillated water) $\mathrm{pH} 4.2$ (A5533; Sigma) for 5 to 10 minutes and thoroughly washed.

Toluidine blue

Chondrog enic differ entiation was evaluated by toluidine blue staining after 3 -week culture. For toluidine blue, the cells were fixed with ethanol $70 \%$ for 1 minute, ethanol $90 \%$ for 1 minute and absolute ethanol for 1minute, then toluidine blue was added ( $1 \mathrm{~g}$ toluidine blue, $1 \mathrm{~g}$ sodium borate $/ 100 \mathrm{~mL}$ of water) (198161; Sigma).

\section{Flow cytometry}

Cells from passage four were used to analysis of cell surface markers. The cells were washed with PBS, and then detached from the plastic with TryPLE (Gibco ${ }^{\star}$ ). The cells obtained were stained for CD14 (FITC), CD19 (APC), CD29 (PE), CD31 (PE), CD34 (PE), 
CD45 (PerCP-Cy5.5), CD73 (PE), CD90 (APC), CD105 (PE), CD106(FITC), CD117 (PE), CD133 (APC), CD166 (PE), HLA-DR (PerCP-Cy5.5) and HLA-I (FITC), and the respective isotype controls (BD Biosciences, San Jose, CA; eBiosciences, San Diego, CA, USA; Biolegend, San Diego, CA).

After staining, the tubes were incubated at room temperature for 30 minutes, followed by a wash st ep; the cell pellet was resuspended, measurements were

Chart 1. Expansion o hMSCs from disposable and reusable sets

\begin{tabular}{|c|c|c|}
\hline Sample & $\begin{array}{l}\text { Input of mononuclear } \\
\text { cells } \times 10^{5}\end{array}$ & $\begin{array}{c}\text { Output of hMiSC } \times 10^{5} \\
\text { on passage } 4\end{array}$ \\
\hline 1 & 100 & 30 \\
\hline 2 & 20 & 26.5 \\
\hline 3 & 32 & 20 \\
\hline 4 & 2.7 & 21.0 \\
\hline 5 & 1.0 & 16.7 \\
\hline 6 & 0.5 & . \\
\hline
\end{tabular}
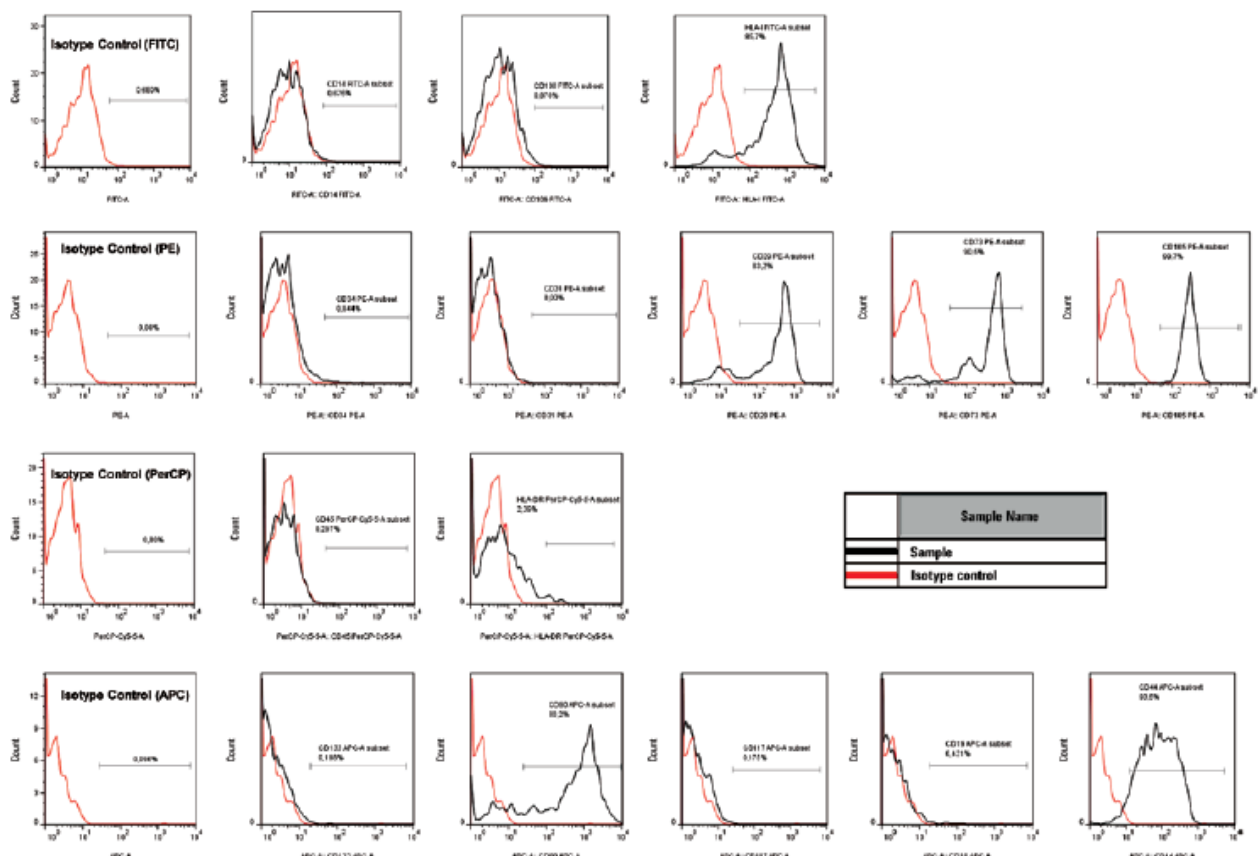

Figure 3. Representation of fure experiments. The first ronur of gaphics represents the isotype controls that were used for each group of antibodes. The other graphics overlay the isctype contrd (red) and the marker (blue). The bar represents the peroent age of cells positive for each researched marker. MSCs were negative or presented very low positivity for CD 14, CD 19, CD31, CD 34, CD45, CD117, CD133, CD 106, HLA-DR; and orer 898 for CD29, CD44, CD73, CD90, CD 105 e HLA- 


\section{Differentiation of hMSC}

hMSCs were also characterized by their ability to differ entiate into cells of three different lineages. All five samples obtained either from reusable or dis posable filters differentiated into cells of the thr ee lineages.

\section{Adipogenic differentiation}

Undifferentiated hMSCs (Figure 4A) were cultured in the presence of adipogenic medium for 21 days, resulting in the formation of cytoplasmic lipid droplets (Figure 4B). For better visualization, cells were stained with Oil Red $O$, which stains lipid droplets within the cells (Figure 4C).

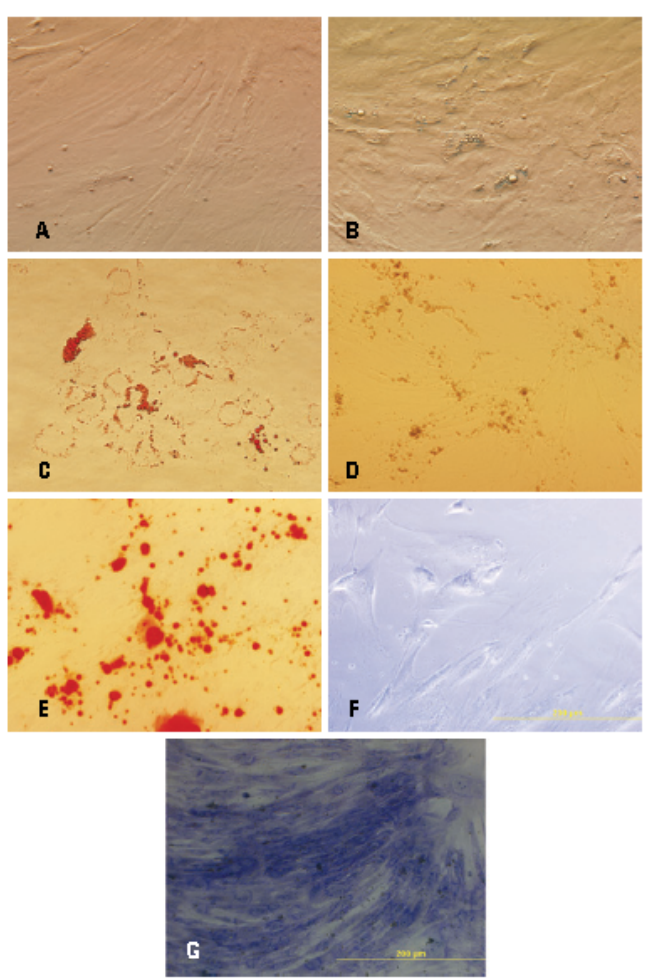

Figure 4. (A) Undfferentiated mesenchymal stem cells - CTRL (40x). (B) Lipid droplet formation within cells cultured in adpogenic medum (40x). (C) Lipid
droplets stained writh Oil Red $\mathrm{O}$ in cells cultured in adpogenic medum (40x). (D) droplets stained worth Oil Red in oells cultured in adpogenic medum (40x). (D) Calcium deposition in œells cultured in osteogenic medium (40K). (E) Calcium
deposition stained vvith Alizarin Red in œells cultured in osteogenic medium deposition stained writh Alizarin Red in cells cultured in osteogenic medium
(40k). (F) Morphologc changes in cells cultured in chondrogenic medum (40x). (F) Morphologc changes in cells cultured in chondrogenic medum (40x). (G) Proteoghy cantrich m
chondrogenic medium (40x)

\section{Osteogenic differentiation}

Undiffer entiated hMSC were cultured in the presence of osteogenic medium for 21 days, resulting in the formation of a calcium matrix (Figure 4D). For better visualization, cells were stained with Alizarin Red, which stains calcium (Figure 4E).

\section{Chondrogenic differentiation}

Undifferentiated hMSC were cultured in the presence of chondrogenic medium for 21 days, resulting in the formation of a proteoglycan-rich matrix (Figure 4F). For better visualization, cells were stained with toluidine blue, which st ains prot eoglycans (Figure 4G)

\section{DISCUSSION}

Bone marrow derived hMSCs are the best well char acterized source of stem cells, which have been used in most clinical trials, such as studies on prevention of graft versus host dis ease (GVHD) by co-infusion of hMSCs with bone marrow or peripheral blood hem atopoietic stem cells. hMSCS are also being tested as a GVHD tr eatment, alone or in combination with cor ticosteroid therapy ${ }^{(15-17)}$.

Besides GVHD pr evention and treatment, hMSCS are involved in a variety of therapies suggestions, such as neurodegenerative disorders, cardiovascular diseases, type 1 diabet es, and others ${ }^{(18-21)}$.

Therefore, bone marrow collection sets are an important source of cells, offering to the scientific community an opportunity to obtain these cells, and to clarify conflicting results - such as the implications of biological variability and differences in conditions that may affect the final therapeutic outcomes - and to provide ans wers to scientific and medical issues.

This study provided evidences that hMSC can be obtained from bone marrow collection reusable and disposable sets.

hMSCs were isolated by their capacity to adhere to plastic, and cultured and expanded after seeding. At the fourth passage, the $c$ ell populations were homogeneous in the expression of CD29, CD44, CD73, CD90, CD105, and HLA-I antigens. Furthermore, hMSCS wer e very low or negative to all hematopoietic stem and progenitor cell markers such as CD14, CD19, CD34, CD45, CD117, CD133 and HLA-DR, and they were also negative for endothelial markers, such as CD31 and CD106. This study shows that hMSCS derived from samples obt ainedfrom reusable or dis posable collection sets were able to give rise, by in vitro differ entiation, to cells of the thre standard mesenchymal cell lineages - adipogenic, osteogenic, and chondrogenic. Thes e cell 
cultures obt ained from filt er sets have fully satisfied the minimal requirements for positive selection markers established by the $\mathrm{ISCT}^{4}$.

Despite the fact that reusable filter sets have smaller pore size, which should retain a larger number of hematons, we were able to obtain mor e cells with better efficiency from the disposable filter sets. This probably occurred due to the fact that this type of filt er presents larger areas for washing. Another possibility is the fact that MSCs are plastic adher ent, and disposable filter sets are enclosed in plastic ${ }^{(22)}$.

\section{CONCLUSION}

This study presented evidences that hMSCS can be obtained from bone marrow reusable collection sets. hMSCS obtained from reusable sets, even with smaller initial number of cells, are able to generate a large number of hMSCS on the fourth passage, and these cells are definitely usable for research purposes as a very ethical source.

\section{REFERENCES}

1. Friedenstein AJ, Deriglasova UF, Kulagina NN, Panasuk AF, RudakowasF, Luriá EA, et al. Precursors for fibroblasts in different populations of hemat opoiatic cells as detected by the in vitro colony assay method. Exp Hem atol. 1974: 2(2):83-92.

2. Deans RJ, Moseley AB. Mesenchymal stem cells: biology and potential clinical uses. Exp Hematol. 2000:28(8):875-84.

3. Bianco P, Gehron Robey P. Marrow stromal stem cells. J Clin Invest. 2000; 105(12):1663-8.

4. Dominici M, Le Blanc K, Mueller I, Slaper-Cortenbach I, Marini F, Krause D, et al. Minimal criteria for defining multipdent mesenchymal stromal cells. The International Society for Cellular Therapy position statement. Cytaherapy. International Socis

5. Ding DC, Shyu WC, Lin Sz. Mesenchymal stem cells. Cell Transplant. 2011; 20(1):5-14.

6. Beyer Nardi N, Siva Meirelles L. Mesenchymal stem cells: is dation, in vitro expansion and characterization. Handb Exp Fharmacol. 2006:(174):24982.

7. Prockop DJ. Marrow stromal cells as stem cells for nonhem at copoietic tissues. Science. 1997:276(5309): 71-4.

8. Kemp KC. Hows J, Donaldson C. Bone marrow-derived mesenchymal stem cells. Leuk Lymphoma. 2005:46(11):1531-44.
9. Peng L, Li H, Gu L, Peng XM, Huang YS, Gao ZL. Comparison of biological characteristics of marrow mesenchymal stem cells in hepatitis B patients and nomal adults. World J Gastroenterd. 2007:13(11):1743-6.

10. Pittenger ME, Mackay AM, Beck SC, J aiswal RK, Douglas R, Mosca JD, et al. Multilineage potential of adult human mesenchymal stem calls. Science 1999:284(5411):143-7.

11. Blazsek I, Delmas Marsalet B, Legras S, Marion S, Machover D, e al. Large scale recovery and characteriation of stromal caltassociated primitive haemopoietic progenitor cells from filter-reained hum an bone marrow. Bone Marrow Transplant. 1999:23(7):647-57.

12. Dvorakova J. Hruba A, Velebny V, Kubala L. Isolation and characteriation of mesenchymal stem cal population entrapped in bone marrav collection sets. Cell Bid Int. 2008:32(9):1116-25.

13. CapelliC, Salvade A, Pedrini O, Barbui V, Gotti E, Bonleri G, et al. Thewashouts of discarded bone marrow collection bags and filters are a very abundant source of hMSCs. Cytotherapy. 2009;11(4):403-13.

14. Sundin M, Remberger M, Lönnies H. Sundberg B, Ringdén O. Le Blanc K. No increased trapping of multipdent mesenchymal stromal cells in bone marrow fitters compared with other bone marrow cells. Oytotherapy. 2008;10(3): 238-42.

15. Lazarus $H M, K \propto$ ON, Dexine SM, Curtin P, Maiarz RT, Holland HK, et al. Cotransplantation of HLA-identical sibling culture expanded mesenchymal stem cells and hem at cooietic stem cells in hematdogic malignancy patients. Biol Blood Marrow Transplant. 2005:11(5):38998

16. Le Blanc K, Rasmusson L, Sundberg B, Götherström C. Hassan M, Uzunel M et al. Treatment of severe acute graft-versus-host disease with third party haplaidentical mesenchymal stem cells. Lancet. 2004;363(9419):143941.

17. Le BlancK, Frassoni F, Ball L, LocatelliF, Roelofs H, Lewis I, LaninoE, Sundberg $B$. Bernardo ME, Remberger $M$, Dini $G$, Egeler RM, Bacigalupo A, Fibbe W. Ringdén D; Develcomental Committee of the Eurcoean Group for Blood and Marrow Transplantation. Mesenchymal stenn cells for treatment of steroidresistant, severe, acute graft-versus-host disease: a phase Il study Lancet 2008:371(9624):157986.

18. Kebriae P, Isola L, Bahceci E, Holland K, Rowley S, McGuirk J, et al. Adult human mesenchymal stem cells added to corticosteroid therapy for the treatm ent of acute graft-versus-host disease. Biol Blood Marrow Transplant. 2009:15(7): 80411.

19. Mazzini L, Mareschi K, Ferrero I, Miglicretti M, Stecco A, Sevvo S, et al. Mesenchymal stromal cel transplant ation in amyotrophic lateral sclerosis: a long-term safety study. Cytotherapy. 2012;14(1):56-60.

20. Williams AR, Hare JM. Mesenchymal sten cells: biology, pathophysiology, translational findings, and therapeutic implications for cardiac disease. Circ Res. 2011:109(8):923-40

21. Mabed M, Shahin M. Mesenchymal stem cel-based therapy forthe treatment of type 1 diabetes mellitus. Cur Stem Cell Res Ther. 2012;7(3):17990.

22. Mageed AS, Pietryga DW, DeHeer DH, West RA. solation of large numbers of mesenchymal stem cells from the washings of bone marraw collection bags: characterization of fresh mesenchymal stem cells. Transplantation. 2007: 83(8): 101926 . 


\subsubsection{DAdOS RECENTES EM IL-17 E TH17 E IMPLICAÇÕES NA DOENÇA DO ENXERTO CONTRA HOSPEDEIRO}

\section{Current data on IL-17 and Th17 cells and implications for graft versus host disease}

Dados recentes em IL-17 e Th17, e implicações na doença do enxerto contra hospedeiro

Manilia Normanton ${ }^{1,2}$, Luciana Cavalheiro Marti ${ }^{1,2}$

\section{ABSTRACT}

Human interleukin 17 was first described in 1995 as a new cytokine produced primarily by activated $\mathrm{T}$ CD4+ cells that stimulate the secretion of IL- 6 and IL- 8 by human fibroblaste, besides increasing the expreseion of ICAM-1. Various authore have reported that IL-17A has a role in the protection of organieme againet extracellular bacteria and fungi due to the capacity of IL-17A to recruit neutrophile to the areas of infection, evidencing a pathological role in various models of autoimmune diseases, such as experimental autoimmune encephalitis and arthritis. The participation of IL-17A has also been described in the acute rejection of organ transplants and graft versus host disease. However, the greatest revolution in research with IL-17 happened in 2000 , when it was proposed that IL-17 cannot be claseified as Th1 or Th2, but rather, simply as a new lineage of IL-17-producing T-cells. These findings modified the previously ectabliahed Th1/Th2 paradigm, leading to the definition of the $\mathrm{CD} 3+\mathrm{CD} 4+$ Th17 cellular subtype and establishment of a new model to explain the origin of various immune events, as well as its implication in the graft versus host diseave that is diecuseed in depth in this article.

Keywords: IL-17; Th17; Graft-host disease

\section{RESUMO}

A interleucina 17 humana foi descrita pela primeira vez em 1995 como uma nova citocina produzida principalmente por células T CD4+ ativadas, que estimulam a secreçäo de IL-6 e IL-8 por fibroblastos humanos, além de aumentar a expressáo de ICAM-1. Vários autores relataram que a IL-17A tem um papel na proteção de organismos contra bactérias extracelulares e fungos devido a capacidade de recrutar neutrófilos para as áreas de infecçáo, evidenciando um papel patológico em vários modelos de doenças autoimunes, como a encefalite autoimune experimental e artrite.
A participação da IL-17A também foi descrita na rejeição aguda em transplantes de órgáos e doença enxerto contra hospedeiro. Entretanto, a maior revoluçāo na peequisa com IL-17 aconteceu em 2000, quando foi proposto que IL-17 náo pode ser classificada como Th1 ou Th2, mas sim como uma nova linhagem de células $T$ produtoras de IL-17. Estes achados modificam o paradigma Th1/Th2 previamente eatabelecido, levando à definição do subtipo celular $\mathrm{CD} 3+, \mathrm{CD} 4+$ Th17 e ao estabelecimento de um novo modelo para explicar a origem de vários eventos imunes, como também suas implicaçōes na doença enxerto contra hospedeiro, que são bem discutidas neste artigo.

Descritores: IL-17; Th17; Doença enxerto contra hospedeiro

\section{INTRODUCTION}

Graft versus host disease (GVHD) is an important clinical complication after hematopoietic stem cell transplantation that can occur acutely within 100 days after bone marrow transplantation, or later as chronic GVHD. Acute GVHD generally affects the skin, liver, and intestinal tract, whereas in its chronic form, the disease can extend to the lung, eyes, and mucous membranes ${ }^{(1)}$.

GVHD initially develops because donor T-cells firstly recognize host alloantigens and become activated. Among the cells involved in GVHD, T helper 1 (Th1) cells are considered the main triggers of the process. These are interferon gamma (IFN $\gamma$ )secreting cells that express the T-box transcription factor (T-bet). However, experimental models of GVHD have 
shown that elimination of Th1 cell activity does not suppress the development of the disease. The description of the cytokine interleukin 17 (IL-17) in 1995 and the subsequent recognition of IL-17secreting Th cells as a distinct subset named Th17, prompted the investigation of several diseases whose immunopathology could not be totally or partially ascribed to Th1 cells. It was soon determined that IL-17 participated in the process of acute rejection of organ transplantation $(2, s)$.

Thus, the investigation of Th17 cells and IL-17 became especially important concerning GVHD.

In 1995, Yao et al. first described human IL-17, which is mainly produced by activated Th $\mathrm{CD} 4+$ cells. It stimulates the secretion of interleukin 6 (IL-6) and interleukin 8 (IL-8) by human fibroblasts and enhances the expression of the intercellular adhesion molecule 1 (ICAM-1) $)^{(8)}$.

Subsequently, mouse and human IL-17 receptors (IL-17RA) have been cloned; IL-17RA is considered the receptor for IL-17 and is highly expressed and distinct compared to other cytokine receptors ${ }^{(4.5)}$.

The IL-17 family includes seven me mbers (IL-17 or IL-17A, IL-17B, IL-17C, IL-17D, IL-17E or IL-25, IL-17F, and the viral homologue vIL-17 or ORF13), and nowadays as many as five different receptors have been described ( ${ }^{(6)}$.

Several reports have proposed that IL-17A has a role in the protection against extracellular bacteria and fungi because of its ability to recruit neutrophils to infected areas. However, it soon became evident that IL-17 participates in the pathology of several autoimmune models of disease, such as experimental autoimmune encephalomyelitis (EAE) and arthritis (7-10).

Nevertheless, the major revolution in $\mathrm{IL}-17$ research occurred in 2000 when Infante-Duarte et al. proposed that IL-17 should not be classified as a Th1 or Th2derived cytokine, but as a novel T-cell lineage producing IL-17A, as is proposed in figure 1 . This concept modified the established Th1-Th2 paradigm leading to the definition of the new Th17 cell subset, and offered new perspectives to the study of several immunological diseases and mechanisms of T-cell regulation. The Th17 cell subset comprises IL-17-secreting cells that express the transcription factor RAR-related orphan receptor gamma (ROR $\gamma t)^{(1112)}$.

Therefore, presently, four basic subsets of differentiated Th cells are recognized, each secreting distinct signature cytokines and expressing characteristic transcription factors, as is summarized in figure 1.

Interleukin-17 and Th17 were first implicated in GVHD physiopathology in $2007^{(2)}$. This review includes

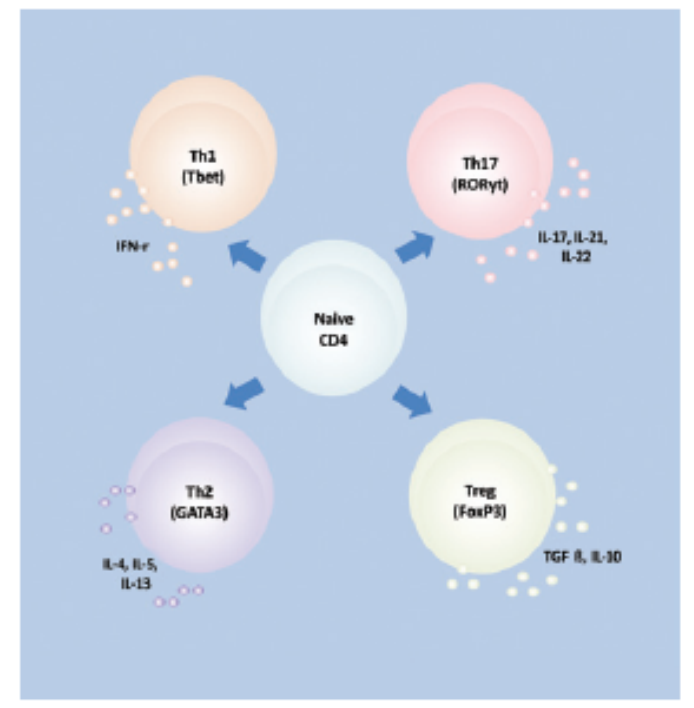

Figure 1. Nave CD4 T-cels can differentiate into diverse phenotypes by cytokines present in the microenvironment where they prolferate. Signaling by cytokines leads to the expression of their transcription factors (Tbet for Th1. RORint for Th17, GATA3 for Th2, and FOX P3 for Tregl and the synthesis of their so-called signature cytokines. Adapted from Teshima, 2011 (19

the indexed publications that refer to the relationship of GVHD with Th17 since their first appearance in scientific literature.

\section{OBJECTIVE}

To report the evidence of Th17 and/or IL-17 involvement in the physiopathology of graft versus host disease.

\section{METHODS}

This study is a descriptive exploratory narrative review of literature.

Literature search strategies were developed using the medical subject titles "Th17 cells" and "graft versus host disease" and all MeSH correlated terms as described on chart 1 . Thus, these terms were used to correlate Th17 with GVHD.

The database was consulted during May 2012 at Medline using the National Center for Biotechnology Information (NCBI) PubMed interface.

We found scientific studies published from 2007 to 2012 . This search retrieved 47 articles, and 19 were omitted according to the exclusion criteria shown on chart 2 . We found 28 relevant articles. 
Chart 1. MeSH guiding question

\begin{tabular}{|c|c|c|}
\hline MeSH terms & And & MeSH terms \\
\hline $\begin{array}{l}\text { Th17 cells } \\
\text { OR all felds Cel, Th17 } \\
\text { Of all felds Cels, Th17 } \\
\text { Of all felds Th17 cel } \\
\text { Search 'Th17 cell" [MeSH Tems] OR (Cell, Th17) } \\
\text { OR (Cells, Th17) OR (Th17 cell) }\end{array}$ & & 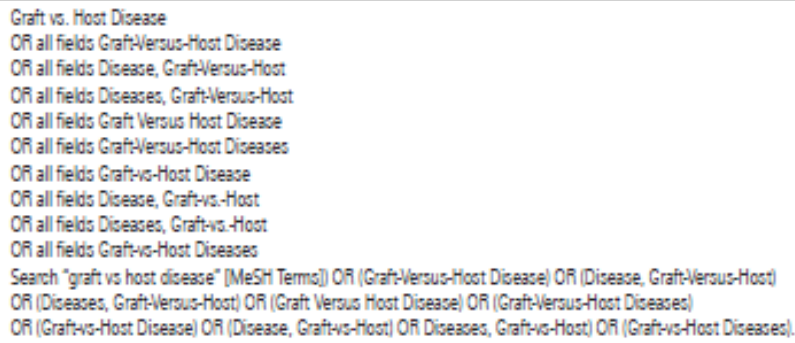 \\
\hline
\end{tabular}

\section{Chart 2. Exclusion criteria chart}

N Article

1 Novel role for surfactant protein A in gastointestinal graft-versus-host disease. Gowdy KM, Cardona DM, Nugent JL, Giamberardino C, Thomas JM, Mukheriee S, Martinu T, Focter WM, Plewy SE, Pastva AM, Whight JR, Paimer SM J Immunol. 2012 May 15;182101:4097-905.

2 Immune modulation of inflammatory condifions: regulatory T-eells for teament of GuhD. Haase D, Stanke M, Puan KJ, Lai TS, Rotaschke O.Immund Fes. 2012 Mar 15

3 An absence of donor TH17 differentiztion ameiorates demal tisoue damage. Cherg H, Song GL, Fan B, Tian J, Yan ZL, Chen W Xu KL L L ZY, Zeng LX Znonghua Yi Xue Za Zhi. 2011 Jul 12:91/26):1843-6. Chinese.

4 H.man TT17 cels are long-fived efector memory cels. Kryczek L, Zhao E, Liu Y, Wang Y, Vatan L, Steiga W, Moyer J, Kimczak A, Lange A, Zou W. Soi Trans| Med 2011 Oet 12:3104: 104ra100

5 Future perspecives: should Th17 cels be considered $\mathrm{z}$ a pocsible therapeufic target in acute myeloid leukemia patients reseiving alogeneic vien cell transplantation?' Ersver E, Melve GK, Bnuserud O. Cancer Immunol Immunother. 2011 Dec;6012):1669-81. Epub 2011 Oct 12. Review.

6 Diminished regulatory T-eells in cutareous lesions of thymoma-sssociated mult-organ autoimmunity. a nenly described paraneoplsctic auscimmune disorder with faral clirical course. Hanatusa T, Asukizawa H, Kitaba S, Murota H, Umegaki N. Terao M, Sano S, Nakagini T, Okumura M, Karayama L.Cin Exp Immunol. 2011 Nov; 166/2):164:70.

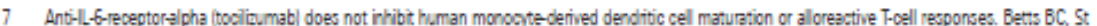
Angelo ET, Kernedy M. Young JW. Blood. 2011 Nov 10;118191:5340-3

8 Mesenchymal stem oell effects on T-sell effector pathways. Duffy MM, Fitter T, Ceredig R, Giffn MD. Stem Cell Res Ther 2011 Aug 11;24,34.

9 DO in human gut grat:vessushoost disease. Ratajazak P, Janin A. Peffeult de Larour F, Koch L. Roche B, Munn D, Blazar BR, Socié G. Biol Blood Marrow Tansplant. 2012 Jan; $1811: 150-5$

10 The role of Th17 oels in early onset of mice acute grat versas host disease Cheng H, Zeng LY, Pan B, Song GL, Tian J, Chen C, Yan ZL, L ZY, Xu KL Znonghua Xue Ye Xue Za Zhi. 2011 Mar, 32/5):322.5. Chinese.

11 Detection of Th17/treg cellassociated or:okines in peripheral blood of patients with grattversushost disease and its clirical significance. Wang $\mathrm{s}$ Wang XB, Wang J, Lu HL, Geng LQ, Ding KY, Sun ZM. Zhongguo Shi Yan Xue Ye Yue Za Zhi. 2011 Apr;1922:422-6. Chinese

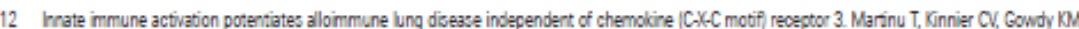
Kelly FL, Snyder LD, Jang D, Foster WM, Garantiotis S, Belperio JA, Noble PW, Palmer SM.J Heart Lung Transplant. 2011 Jun; 3066:717-25.

13 Host-miercbe interactions in stem cel transplantation: recogrizing Candida in infection and inflammation van der Velden WJ, Plantinga TS, Dornely

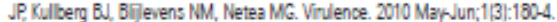

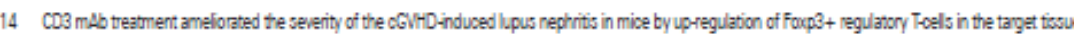

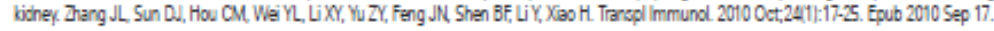

$15 \mathrm{Cbl}-\mathrm{b}(-4)$ T-cels demonstrate in vivo resistance to regulatory T-cels but a contedt-dependent resistance to TGF-beta. Adams CO, Housley WJ, Bhowmick S, Cone RE, Flajen TV, Forouhar F, Clark FB. J Immunol. 2010 Aug 15;105/4; 2051-8.

16 The incidence of acsa graftversushost disease increases with Candida colorization depending on the dectin-1 gene status. van der Velden WJ, Plantinga TS, Feuth T, Dorrelly JP, Netea MG, Billevens MM. Cin Immunol. 2010 Aug;:136/21:302-6. Epub 2010 May 10.

17 G-CSF induces a potentialy tolerant gene and immunophenotpe profle in T-cels in vivo. Toh HC, Sun L, Soe Y, Wu Y, Phoon YP, Chia WK, Wu J, Wong KY, Tan P. Cin Immunol. 2009 Jul; 13211:83-92

18 Isentification of IL-18 and Th17 oells in sahray glands of patients with S.jpgren's syndrome, and amplification of I-17-mediated secretion of inflammatory cytokines from salivary gland oells by IL-18. Sakai A. Sugawara Y, Kurcishi T, Sasano T, Sugawara S.J Immunol. 2008 Aug 15; 181(4):2898-906.

19 Pathobiology of transforming growth factor beta in cancer, fibrocis, and immunologic disease, and therapeutic considerations. Prud'homme GJ Lab Invest. 2007 Nov; $87 / 11$ : 1077-91. Epub 2007 A.g 27. Review.

Exclusion criteria

Not related

to the Th17 topic

Not related

to the Th17 topic

Article in Chinese

Not related

to the GVHD topic

Not related

to the GVHD topic

Not related

to the GVHD topic

Not related

to the Th17 togic

Not related

to the Th17 topic

Not related

to the Th17 togic

Artele in Chinese

Atrole in Chinese

Not related

to the Th17 topic

Not related

to the GVHD topic

Not related

to the Th17 topic

Not related

to the Th17 topic

Not related

to the Th17 topic

Not relates

to the GVHD topic

Not related

to the GVHD topic

Not related to the GVHD

topis 


\section{RESULTS}

Twenty-eight articles on IL-17 related to GVHD were found in our search and chart 3 summarizes each article database, authors, publication year, study type, main theme, and country of origin.

Among these articles, 19 were original research reports carried out in animal models, 4 were clinical studies and 5 were reviews.

The nineteen articles on experimental GVHD reviewed here did not show uniform results, mainly because of different experimental protocols used to investigate the relationship between Th17 and GVHD. Other reasons that explain discrepancies among the several studies are related to the animal models used, to the inactivation of different genes (knockouts), or to differences in the pre-grafting conditioning regimens. Some of the selected articles made major contributions to the field. For instance, Chen et al., 2007, first discussed the imbalance between pro-inflammatory and regulatory cell populations and their respective phenotype in the development of GVHD. Also of note, Carlson et al., in 2008, obtained the in vitro differentiation of Th17 cells, and by infusing these cells into the animals, were able to demonstrate that GVHD developed independently of IFN $\gamma$. In addition to these, there are several other articles that will be discussed in detail in the next section.

The four clinical studies described and established correlations between Th17 and IL-17 in human GVHD Some indirect evidence, such as the correlation between Th17/Treg ratios and disease scores, as well as the association between the number of infused Th17 cells and GVHD occurrence are very important in the clinical setting. The few clinical studies reported on this subject are, of course, justified by the inherent limitations in obtaining adequate samples from the patients and the severity of their disease.

The five reviews on the subject summarize the existing research and critically analyze the results by pointing out the consensus as well as the yet unclear aspects.

\begin{tabular}{|c|c|c|c|c|c|c|c|}
\hline $\mathbf{N}$ & Database & Title & Authors & Year & Origin & Type of study & Main themes \\
\hline 13 & P.tulled & $\begin{array}{l}\text { Absence of regulatory T-cel control of TH1 and TH17 } \\
\text { cells is responsible for the astoimmunemediated } \\
\text { pathology in chronic graft-versus-host disesse. }\end{array}$ & $\begin{array}{l}\text { Chen X, Vodanoviowankovic S, Joknson B, } \\
\text { Keler M, Komorowski f, Drobyski WR. }\end{array}$ & 2007 & USA & Experimental & $\begin{array}{l}\text { Treg, Th17 oell and } \\
\text { chroric GVHD }\end{array}$ \\
\hline 14 & Publued & $\begin{array}{l}\text { Interferon-gamma regulates idiopathic pneumoria } \\
\text { syndrome, a Th17+CD4+T-cel/-mediated graft:- } \\
\text { versushost disease. }\end{array}$ & $\begin{array}{l}\text { Mavermarn N, Burian J, von Garnier C, } \\
\text { Dimhoter S, Germano D, Schuett C, } \\
\text { Tamm M, Bingisser R, Eriksson U, } \\
\text { Hunzker L. }\end{array}$ & 2008 & USA & Expenimental & $\begin{array}{l}\text { Th17 cel, CD4 } \\
\text { T-cel, idiopathic } \\
\text { pneumoria } \\
\text { apndrome and GVHD }\end{array}$ \\
\hline 15 & PubMed & $\begin{array}{l}\text { Akesence of donor Th17 leads to augmented Th1 } \\
\text { difierertiation ard evasetated acute grat-vesus-host } \\
\text { disease. }\end{array}$ & $\begin{array}{l}\text { YiT, Zhao D, Lin CL, Zhang C, Chen Y, Todorovl, } \\
\text { Leiton T Kardeel F, forman S, Zerg D. }\end{array}$ & 2008 & USA & Experimental & $\begin{array}{l}\text { Th17 cell, Th1 cell, } \\
\text { acute GVHD }\end{array}$ \\
\hline 16 & PublMed & $\begin{array}{l}\text { IL-17 contibutes to } \\
\text { CD4-mediated graft-versis-host disesse. }\end{array}$ & 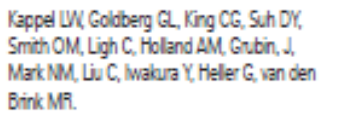 & 2009 & USA & Experimental & IL-17, GVHD \\
\hline 17 & PubMed & $\begin{array}{l}\text { In vito-differentiated TH17 cels mediate letal acute } \\
\text { graft-versushocst disease with severe cutanecus and } \\
\text { pulmonay pathologic manifestations. }\end{array}$ & $\begin{array}{l}\text { Carison M, West ML, Coghil JM, } \\
\text { Panoskaltwi-Mortari A, Blazar BR, } \\
\text { Serody J5. }\end{array}$ & 2009 & USA & Experimental & $\begin{array}{l}\text { Th17 cell, GVHD, } \\
\text { cutareous and } \\
\text { pulmonary } \\
\text { manifectations. }\end{array}$ \\
\hline 18 & Publled & $\begin{array}{l}\text { Reciprocal differentiation and tissuespecific } \\
\text { pathogenesis of Th1, Th2, and Th17 cels in } \\
\text { graft-versus-hoct disease. }\end{array}$ & $\begin{array}{l}\text { Yi T, Chen X, Wang L, Du G, Huang D, } \\
\text { Zhao D, Johnston H, Young J, Todorowl, } \\
\text { Umetwu DT, Chen L, Wakura Y, Kanded F, } \\
\text { Forman S, Zeng D. }\end{array}$ & 2009 & USA & Experimental & $\begin{array}{l}\text { Th1 cel, Th2 cell } \\
\text { and Th17 cel, } \\
\text { GVhD, tissue } \\
\text { association }\end{array}$ \\
\hline 19 & PublMed & $\begin{array}{l}\text { IL-21 blockade reduces grat:versushoct disease } \\
\text { mortality by s.pporting inducible Tregulatory cell } \\
\text { generation. }\end{array}$ & $\begin{array}{l}\text { Bucher C, Koch L, Vogtenhuber C, } \\
\text { Goren E, Munger M, Panoskaltisis-Mortari A. } \\
\text { Sivakumar P, Blazar BR. }\end{array}$ & 2009 & USA & Experimental & IL-21, GVHD, Treg \\
\hline 20 & PubMed & $\begin{array}{l}\text { Absence of L-23, } 19 \text { in donor allogeneic cells reduces } \\
\text { montaliny from acute GVHD. }\end{array}$ & Thompson JS, Chu Y, Glass JF, Brown SA & 2010 & USA & Experimental & $\begin{array}{l}\text { LL-23p 19, motaity, } \\
\text { GVHD }\end{array}$ \\
\hline 21 & P.tuled & $\begin{array}{l}\text { Thelper } 17 \text { cels are sufficient but not necsssary to } \\
\text { induce acute graft-versus-host disease }\end{array}$ & $\begin{array}{l}\text { Idlozan C, Yu Y, Liu C, Liang Y, Yi T, } \\
\text { Anasetti C, Yu XZ }\end{array}$ & 2010 & USA & Experimental & Th17 cel, GVHD \\
\hline 22 & PubMed & $\begin{array}{l}\text { STAT3 signaling in CDA+ T-osls is critical for the } \\
\text { pathogenesis of chroric sclerodematous gratt. } \\
\text { versus host disease in a murine model. }\end{array}$ & $\begin{array}{l}\text { Radojcic V, Pletreva MA Yen HR, liceric S, } \\
\text { Panoskaltis-Mortari A. Gilam AC, Drake } \\
\text { CG, Elazar BR, Luarik L. }\end{array}$ & 2010 & USA & Experimental & $\begin{array}{l}\text { Stak, Th17 cell, } \\
\text { GVHD }\end{array}$ \\
\hline
\end{tabular}




\begin{tabular}{|c|c|c|c|c|c|c|c|}
\hline $\mathbf{N}$ & Database & Title & Authors & Year & Origin & Type of study & Main thennes \\
\hline 23 & PubMed & $\begin{array}{l}\text { Interleukin-17-producing cells increase among CD4+ } \\
\text { lymphocytes before overt marifestation of acste } \\
\text { graft-versus-host disease. }\end{array}$ & $\begin{array}{l}\text { Dlubek D, Turlej E, Sedaimirska M, } \\
\text { Lange J, Lange A }\end{array}$ & 2010 & Poland & Clinical & II-17, GVHD \\
\hline 24 & PublMed & $\begin{array}{l}\text { Curaneous GVHD is associated with the expansion of } \\
\text { tissuelocalized Th1 and not Th17 cells. }\end{array}$ & $\begin{array}{l}\text { Broady R, Yu J, Chow V, Tantworawit A, } \\
\text { Kang C, Berg K, Martinka M, Ghoreishi M, } \\
\text { Dutz J, Levings MK. }\end{array}$ & 2010 & Canada & Clirical & $\begin{array}{l}\text { Th1 oell, Th17 cell, } \\
\text { GVHD, cutareous }\end{array}$ \\
\hline 25 & PublMed & $\begin{array}{l}\text { Development of a } 7 \mathrm{TH} 117 \text { immune response during } \\
\text { the induction of murine spngeneic graft-versusthost } \\
\text { disease. }\end{array}$ & $\begin{array}{l}\text { Brandon JA, Jernings CD, Kaplan AM, } \\
\text { Bnsoon J5. }\end{array}$ & 2010 & USA & Experimental & $\begin{array}{l}\text { IL-17, CD4+ T-sels, } \\
\text { transplantation }\end{array}$ \\
\hline 26 & P.bMed & $\begin{array}{l}\text { Homing in on acute grat vs host disease: tissue } \\
\text { specific Tregalatory e Th17 cels. }\end{array}$ & Engehardt $B G$, Crowe JE & 2010 & USA & Review & Th17, GVHD, Treg \\
\hline 27 & P.t.lMed & New perspectives on the biology of acite GVHD. & Paczesny S, Hanauer D, Sun Y, Reddy P. & 2010 & USA & Review & $\begin{array}{l}\text { GVHD, allogeneic, } \\
\text { transplantaion, } \\
\text { bone marow }\end{array}$ \\
\hline 28 & PublMed & Th17/Treg ratio in human grait-versushost disease. & $\begin{array}{l}\text { Ratajerak P, Jarin A, Peffault de Latour R, } \\
\text { Leboeuf C, Desveaux A, Kepvantar K, } \\
\text { Robin M, Clave E, Douay C, Ouinquenel A. } \\
\text { Fichereas C, Betheau P, Mary JY, Socié G }\end{array}$ & 2011 & France & Cirical & $\begin{array}{l}\text { Th17 cel, } \\
\text { Treg, 6VitD, } \\
\text { gatrointestinal }\end{array}$ \\
\hline 29 & PublMed & $\begin{array}{l}\text { IL-17-producing Tcels contribuse to acute GVHD in } \\
\text { patents undergoing to non-manipulated blood and } \\
\text { marrow transplantation. }\end{array}$ & Zhao XY, Xu LL, Lu SY, Huang XJ. & 2011 & China & Cirical & $\begin{array}{l}\text { L-17, Th17 colls, } \\
\text { acite GVHD }\end{array}$ \\
\hline 30 & PubMed & $\begin{array}{l}\text { Sequential activation of inflammatory signaling } \\
\text { pathways during grat:vesushthoct disease (GVHD): } \\
\text { early role for STAT1 and STAT3. Cell Immunol. } \\
2011,268(1), 37.46 \text {. }\end{array}$ & $\begin{array}{l}\text { Ma HH, Ziegles J, Li C, Sepulveda A. } \\
\text { Beder A Grandis J, Lentzsch S, } \\
\text { Mapara MY. }\end{array}$ & 2011 & USA & Experimental & $\begin{array}{l}\text { Stati, Stat3, GVHD, } \\
\text { intlammation }\end{array}$ \\
\hline 31 & PublMed & $\begin{array}{l}\text { Blockade of IL-6rignaling inhibits the pathogenesis of } \\
\text { CD4+ T-esll-mediated lathal gratt-versushost reaction } \\
\text { against minor histocompatbility antigen. }\end{array}$ & $\begin{array}{l}\text { Noguchi D, Wakita D, Ohkuri T, Tajma M. } \\
\text { Chamoto K, Kramura H, Nishimura T. }\end{array}$ & 2011 & Japan & Experimertal & IL-6, CO4, GVHD, \\
\hline 32 & PubMed & $\begin{array}{l}\text { Prevention of GVHD while sparing GVL effect by } \\
\text { targeting Th1 and Th17 transciption factor Thet and } \\
\text { ROfix in mice. }\end{array}$ & $\begin{array}{l}\text { Yu Y, Wang D, Liu C, Kaosaard K, Semple K, } \\
\text { Anaseti C, Yu XC. }\end{array}$ & 2011 & USA & Experimertal & $\begin{array}{l}\text { GV, GVHD, Th17 } \\
\text { cell Thet }\end{array}$ \\
\hline 33 & Publad & Th1 and Th17 join forces for acuse GVHD & Teshima T & 2011 & Japan & Reviaw & $\begin{array}{l}\text { Th1 oell, Th17 cell, } \\
\text { GVHD }\end{array}$ \\
\hline 34 & PubMed & $\begin{array}{l}\text { Regulatory T-oells and I-17-producing cells in graft- } \\
\text { versus-host disease. }\end{array}$ & Teshima T, Masda Y, Ozaki K. & 2011 & Japan & Reviaw & $\begin{array}{l}\text { Treg, IL-17 cell, } \\
\text { GVHD }\end{array}$ \\
\hline 35 & PublMed & $\begin{array}{l}\text { Abrogation of donor T-cell l.-21 sigraing leads to } \\
\text { tissuespecific modulation of immunity and separation } \\
\text { of GVHD from GVL. }\end{array}$ & $\begin{array}{l}\text { Harash AM, Kappel LW Ym M, Nejat FA, } \\
\text { Goldberg GL, Smith OM, Fao UK, } \\
\text { Dykstra L, Na IK, Holland AM, Dudakor JA. } \\
\text { Liv C, Mupphy GF, Leonard WU, Heller G, } \\
\text { van den Brirk MR. }\end{array}$ & 2011 & USA & Experimental & L-21, GVHD, GVL \\
\hline 36 & Publued & 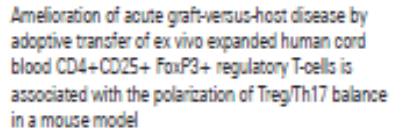 & $\begin{array}{l}\text { Yang J, Fan H, Hao J, Ren Y, Chen L, Li G, } \\
\text { Xje R, Yang Y, Cian K, Liu M }\end{array}$ & 2012 & China & Experimental & Treg, Th17 cel \\
\hline 37 & PubMed & $\begin{array}{l}\text { Protective role of T-bet and Th1 cytokines } \\
\text { in pulmonaly grat:-versushost diease and } \\
\text { peribronchiolar fbrosis }\end{array}$ & $\begin{array}{l}\text { Gowdy KM, Nugent JL, Martinu T, Potts E, } \\
\text { Snyder LD, Foster WM, Palmer SM. }\end{array}$ & 2012 & USA & Experimental & $\begin{array}{l}\text { Th1 oell, Tbet, } \\
\text { GVHD }\end{array}$ \\
\hline 38 & PubMed & $\begin{array}{l}\text { Synthetic retinoid Am30 ameliorates chronic } \\
\text { graft-versus-host disease by down-regulating Th1 } \\
\text { and Th17. }\end{array}$ & $\begin{array}{l}\text { Nishimoi H, Masda Y, Teshima T, } \\
\text { Sugivama H, Kobayashi K, Yamasujuj, } \\
\text { Kasohisa S, Uryu H, Takeuchi K, Tanaka T, } \\
\text { Yoshino T, Wakbura Y, Tarimoto M. }\end{array}$ & 2012 & Japan & Experimertal & $\begin{array}{l}\text { Chronis GVHD, Th1 } \\
\text { cell, Th17 cell }\end{array}$ \\
\hline 39 & PublMed & $\begin{array}{l}\text { Atered balance between Tht and Th17 cells in } \\
\text { creulation is an indicator for the severity of murine } \\
\text { acute GVHD. }\end{array}$ & $\begin{array}{l}\text { Pan B, Zeng L, Cheng H, Song G, Chen C, } \\
\text { Zhang Y, Li Z, Xu K. }\end{array}$ & 2012 & China & Experimental & $\begin{array}{l}\text { Th1 oefl, Th17 ofll, } \\
\text { GVHD }\end{array}$ \\
\hline 40 & PublMed & $\begin{array}{l}\text { The L.-17 differentiation pathway and its role in } \\
\text { transplart cutcome. }\end{array}$ & Serody J5, Hill GR. & 2012 & USA & Review & $\begin{array}{l}\text { Acute, chronic } \\
\text { 6VIHD, Th1 cel, } \\
\text { Th17 cell }\end{array}$ \\
\hline
\end{tabular}




\section{DISCUSSION}

The 28 articles were grouped according to the main focus of the reported research:

(A) Evidence that Th17 cells mediate GVHD in murine models of the disease

In 2008, Carlson et al. developed a protocol to differentiate naive T-cells into Th17 cells in vitro. The main steps and markers of the Th17 differentiation pathway are shown in figure 2. By using purified Th17 cells differentiated from wild-type mice or from mice deprived of the IFN $\gamma$ genes (IFN $\gamma-/-$ ), the authors showed that Th17 cells can mediate lethal GVHD regardless of IFN $\gamma$-production. These cells triggered severe pulmonary and cutaneous manifestations in mice $^{(17)}$. The Th17 competence in inducing GVHD was further confirmed by Iclozan et al., 2010. Furthermore, in the latter study, Th17 cells were identified as more potent than Th1 cells, since small numbers of Th17 cells aggravated the lethality of GVHD in several allogeneic recipients, which demonstrates the pathogenic potential of the Th17 subset $^{(21)}$.

In contrast, also in 2008, Yi et al. showed that the transfer of $\mathrm{IL}-17-/$ - donor T-cells to recipient mice exacerbates acute GVHD; worsening of the disease was associated with the expansion of Th1 differentiation and IFN $\gamma$ production. It was also observed that IL17 added at low doses to IL-17-/- donor cells reduced the frequency of IFN $\gamma$-producing cells, resulting in mitigated acute $\mathrm{GVHD}^{(15)}$. In contrast to the preceding articles, this one showed that Th17 cells or IL-17 absence leads to Th1 increase and GVHD exacerbation, and the administration of $\mathrm{IL}-17$ can mitigate GVHD.
In sequence, Kappel et al., 2009(15), demonstrated that donor-derived CD4T-cells after transplantation can produce IL-17 and IFN $\gamma$, suggesting that these cytokines are not mutually exclusive and that a single cell is able to produce both of them. They also showed that IL-17 favors GVHD development when purified CD4 T-cells are transferred to allogeneic recipients; however IL-17 is not needed for GVHD development when whole T-cells are transferred to the mice. This article is in accordance with Yi et al. when they state that GVHD can occur in the absence of IL-17, but differs regarding the IL-17 contribution to GVHD, showing that II-17 favors GVHD instead of protecting against it. However, different experimental protocols used by the authors (for instance, diverse conditioning regimens used before transplantation, and the cell populations used) may have contributed to some of the contrasting results ${ }^{(15.16)}$.

The proposal by Yu et al., 2011, is that naive Th cells can differentiate into Th1 and Th17 and mediate GVHD after adoptive transfer into the allogeneic host. In their experiments they used as donor cells T-cells from mice that had disruptions of both T-bet and ROR $\gamma$ t transcription factors, that is, the donor cells were incapable of differentiating into Th1 and Th17 cells. Differentiation occurred instead to Th2 and to T-cells with regulatory phenotypes, resulting in amelioration of established GVHD. They also observed a preserved graft versus leukemia (GVL) condition, which is a response against the original disease, usually leukemia cells ${ }^{(22)}$

An important practical point was raised by Teshima et al., 2011, who made a reference to the paper by Yu et al., 2011, whose results demonstrate that disruption of Thet and ROR $\gamma t$ is beneficial for GVHD without

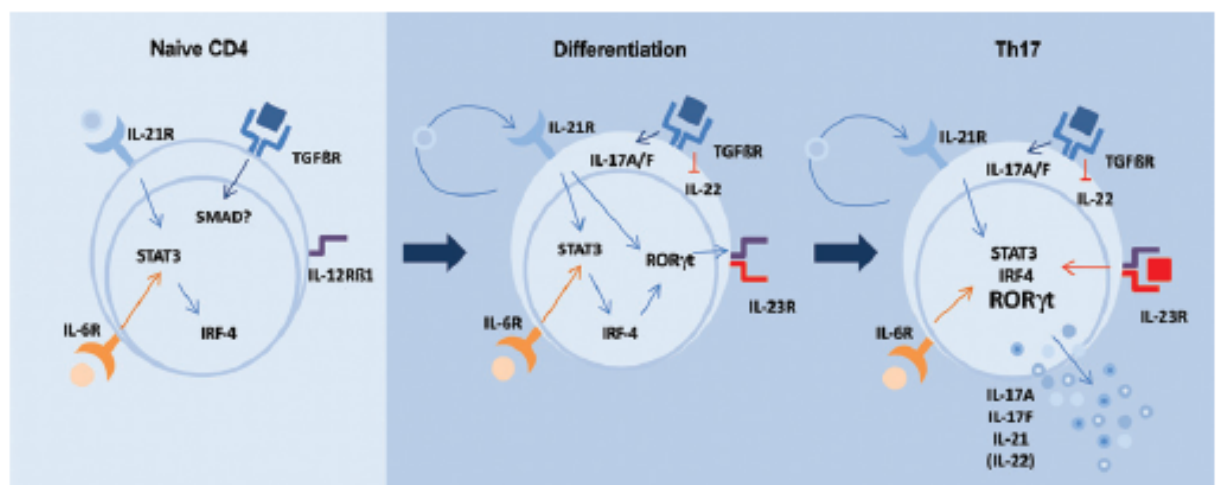

Figure 2. Cytokines IL-21, IL-6, TGFB acting on the receptors of naive T-cells, activate via STAT 3 the transcription factors IRF-4 and RORint, leading to the synthesis of IIL-17 A and IL-17 F, IL-21, and the expression of the functional IL-23 receptor on the membrane. The synthesis of IL-17 and the transcription factor RORY)t are considered the main markers of the Th17 subset. Adapted from Ghilardi and Ouyang, 2007 ra 
affecting GVL. The question is whether abrogation of Th1/Th17 function, should it be considered as a therapeutic approach, would affect the resistance to opportunistic infections, a recognized major problem after transplantation ${ }^{(24)}$

In general, all the abovementioned articles, with the exception of that by Yi et al.(15), showed that Th17 cells or IL-17 participate in either triggering or aggravating GVHD.

(B) Th17/IL-17 in GVHD pathology of selected organs Because GVHD can affect different organs, several investigators have focused on the role of Th17 in organ-specific manifestations of the disease. This topic includes several articles.

Mauermann et al., 2008, report that the transfer of semi-allogeneic bone marrow in combination with a population of CD4+ T-cells lacking IFN $\gamma$ or T-bet exacerbated the lung inflammation in recipient mice. In contrast, wild-type donor CD4+ T-cells mediated minimal inflammation, and CD8 + T-cells played a minor role in idiopathic pneumonia syndrome (IPS) development. Furthermore, absence of IFN $\gamma$ or of IFN $\gamma$ signaling in the recipients' pulmonary parenchymal cells promoted expansion of $I L$-17A-producing cells, thus increasing the severity of lung disease. In contrast, IL-17A depletion reduced the disease severity. Perhaps, as discussed by this article, the presence of IL-17A in the lungs promotes neutrophil and macrophage recruitment, aggravating the disease scenario ${ }^{(14)}$. Relative to organ specificity, a few months later, in 2009, Yi et al. published a new article ${ }^{(18)}$ in which they reported the pathogenesis of GVHD affecting specific organs for the activation of specific Th cell subsets. Th1 were found to be involved in gut and liver damage, whereas the absence of IFN $\gamma$ enhanced lung and skin tissue damage related to $\mathrm{Th} 2$ and $\mathrm{Th} 17$ cell populations. The authors reported a correlation between Th17 and skin damage, sustaining that Th17 cells are important mediators of skin GVHD because of IL-17 activation of STAT3 in keratinocytes, resulting in epidermal hyperplasia. However they did not observe a significant involvement of Th17 with lung damage as had been reported by Mauerman et al. in their previous article. Yet, Yi et al. consider that Th17 can play a minor role in the pathogenesis of idiopathic pneumonia ${ }^{(18)}$

In a prior study ${ }^{(2)}$ done before the structure of IL-23 was determined, Brandon et al. reported the inhibition of Th1 in the murine syngeneic GVHD model by the neutralization of the p 40 chain of cytokine IL-12. However, now it is known that $\mathrm{IL}-23$ shares the subunit p40 with IL-12. Thus, it is unclear whether therapy with II-12p40 has blocked Th1 or Th17 development, or both. Therefore, Brandon et al., 2010, reported a study designed to investigate Th17 involvement in syngeneic GVHD-associated colitis (sGVHD). Their experiments demonstrated a significant increase in the number of Th17 cells in SGVHD animals, but the disease score was not modified by administration of anti-IL-17A monoclonal antibodies, leading to the conclusion that IL-12p40 had acted on Th1 instead of Th17 in the previous study, but not excluding a role for Th17/IL-17 in sGVHD(25).

Another approach to test whether pulmonary GVHD can develop in the absence of Th1 cells used T-bet-deficient mice as cell donors in GVHD models. They concluded that pulmonary GVHD development occurs without Th1 cells, and that the absence of T-bet leads to increased production of both Th17 and Th2-type cytokines; the observed lung fibrosis is enhanced by LPS exposure. In addition, LPS-exposed Allo-T-bet $(-/)$ mice had increased numbers of Th17 cells as well as increased pulmonary IL-17 and IL-13 levels, followed by a reduction in the number of regulatory T-cells ${ }^{(\mathrm{m})}$. Nishimori et al., 2012, investigated Th subsets in chronic GVHD and found up-regulation of Th1, Th2, and Th17 responses. Th1 and Th2 responses were up-regulated first, followed by Th17 cells. Lungs and liver from allogeneic recipients were infiltrated by significantly larger numbers of Th17 cells as compared with the same organs of syngeneic recipients. Reduction of chronic GVHD was seen upon treatment of the mice with $A M 80$, a retinoid that regulates $R A R$ and II-6, down-regulating both Th1 and Th17. Therefore, in this chronic GVHD model, both these populations and possibly $\mathrm{Th} 2$ participate as effector cells, albeit at different time points in the course of the pathogenesis process ${ }^{(35)}$.

(C) The balance between $\mathrm{T}$ regulatory cells and Th1/ Th17 cells in murine models of GVHD

Chen et al., 2007, demonstrated that the autoimmunelike disease that develops as GVHD is attributed to donor-derived CD4 T-cells with Th1 and Th17 cytokine phenotypes. This study importantly describes the unbalanced loss of CD4+CD25+ Foxp3 + cells, known as T regulatory phenotype cells (Treg), associated with the reciprocal increased secretion of pro-inflammatory cytokines by Th1 and Th17 cells, thus leading to pathological tissue damage in GVHD. This study confirms Th1 and Th17 cells as important to GVHD development, and reinforces the role of Tregs as negative 
regulators of this disease. In fact Tregs transferred to animals primed to develop GVHD were able to prevent the disease ${ }^{(18)}$

Engelhardt and Crowe (2010) suggest in their review that Tregs and Th17 cells (but not Th1 cells) are the main T-cell subsets involved in acute GVHD. They hypothesize that both subsets are mutually regulated through retinoic acid, IL-6, and by dendritic cells. Another aspect of the physiology of those T-cell subsets is their homing to lymph node, skin, or gut that is under tight regulation ${ }^{(26)}$.

An excellent review was published by Teshima et al., 2011. They summarize the findings relative to GVHD and Th17 and Treg functions. Based on the accumulated data from experimental and clinical studies, the authors suggest novel future strategies for preventing and treating GVHD, such as Treg cell therapy ${ }^{(36)}$.

Improvement of murine GVHD after adoptive transfer of $\mathrm{T}$ human cord blood-expanded Tregs was described by Yang et al., 2012. Their interpretation is similar to that with the Treg/Th17 balance observed previously in the mouse model; the increase in Treg numbers was accompanied by a decrease in Th17 cells. However, the suppressor activity of in vitro expanded Tregs and their efficacy in acute GVHD prevention are still poorly understood ${ }^{(36)}$.

Pan et al., 2012, reported findings that also confirmed that an altered balance between Th17 cells and Tregs contributes to several kinds of inflammatory diseases, including acute GVHD ${ }^{(39)}$.

(D) Role of other cytokines in the Th17 pathway Interleukin-21 (IL-21) favors Th1 and Th17 differentiation while inhibiting induced regulatory T-cell (iTregs) differentiation. Bucher et al., 2009, demonstrated the IL-21 role in GVHD. Since then, donor T-cell IL-21 production and its II-21R signaling have been essential for GVHD-induced gastrointestinal tract injury and lethality. IL-21/IL-21R signaling blockage was associated with a decrease in IFN $\gamma$ secreting T-cells infiltrating the colon lamina propria, and the consequently diminished disease score. These study data demonstrate that blockade of $\mathrm{IL}-21$ signaling increases iTregs differentiation in vivo, but does not abrogate the graft versus leukemia (GVL) effect. In addition, they also demonstrated that II- 21 signaling blockage did not affect production of perforin or granzymes, and had no direct effect on CD8 T-cells ${ }^{(19)}$.

II- 23 present heterodimers that share a $\mathrm{p} 40$ dimer, but differ by IL-12p35 and IL-23p19. The role of IL-23 to maintain Th17 cells has been shown to be related to its unique dimer $\mathrm{p} 19$, and not to the $\mathrm{p} 40$ dimer Thompson et al., 2010, using an allogeneic model of donor p19-/-mouse, have demonstrated that p19 deficiency in allogeneic donor transplantation reduces acute GVHD severity, but increases IL-17 mRNA and serum levels. These results were discussed by the authors, suggesting the effect of p19-/- may be related to interleukin 22 (IL-22), which is another cytokine produced by Th17 cells (20).

Hanash et al., 2011, demonstrated in a murine model of bone marrow transplantation, that IL-21R knockout donor T-cells mediate decreased systemic and gastrointestinal GVHD in transplant recipients. This reduction in GVHD was associated with expansion of donor Treg cells and with tissue-specific modulation of Th cell function ${ }^{(35)}$.

IL-6 signaling blockade by anti-IL-6 receptor monoclonal antibody administration remarkably inhibited lethal GVHD as was demonstrated by Noguchi et al., in 2011. They observed that anti-IL-6R mAb administration did not impair Th1 cells, but cells that simultaneously secrete INF $\gamma$, IL-17, and tumor necrosis factor alpha (TNF- $\alpha$ ). They also report the increased number of Treg cells in the spleen of treated mice ${ }^{(31)}$.

(E) Th17 signal transduction role in a murine model of GVHD

To study chronic sclerodermatous GVHD development in animal models, Radojcic et al., 2010, used STAT3 knockout mice to abrogate its signaling. They found that STAT3 absence restricts alloreactive T-cell proliferation and expansion in vivo. Although STAT3 abrogation did not impair naive T-cell differentiation into Th1, it promoted natural and induced Treg reconstitution ${ }^{(22)}$.

Sequential activation of signaling pathways during GVHD is the main subject of the article by Ma et al., 2011, which analyzed early STAT1 and STAT3 activation supported by the fact that early STAT3 activation in splenic T-cells is accompanied by II-17 systemic secretion in GVHD animals. They found that PSTAT1 is upregulated in the early stages of GVHD, not only in spleen cells/lymphocytes but also in the liver and colon; while PSTAT3 is upregulated in early stages and persists during GVHD development. However, further studies will be necessary to functionally dissect the role of STAT1 and STAT3 and their crosstalk during GVHD ${ }^{(30)}$.

(F) Clinical studies relating Th17 and human GVHD

Dlubek et al., 2010, investigated IL-17-producing cell presence among peripheral blood mononuclear cells (PBMC) from patients after hematopoietic stem 
cell transplantation (HSCT). All patients presented with an increased number of IL-17-producing cells during hematopoietic reconstitution compared to healthy individuals. However, eight patients developed acute GVHD, displaying lower proportions of IL-17-producing CD4 cells on the day of acute GVHD compared to initial measurements. The author proposes as explanation that these II-17-producing cells might have migrated to the affected tissues during clinical GVHD manifestations. In this study, however there is no evidence of IL-17 cell presence at the tissue site ${ }^{(23)}$.

In addition, Broady et al., 2010, studied blood and skin from patients with acute GVHD. Even though they found increased II-17 cells during immune reconstitution, these cells disappeared from circulation in patients with acute GVHD. Nevertheless, the Th17 cells did not migrate to the skin, since they were not increased at GVHD skin sites compared to healthy controls. In contrast, there were significantly more IFN $\gamma$-producing T-cells at these skin sites compared to the controls. These data support the long-standing paradigm that tissue IFN $\gamma$-producing cells are the main perpetrators of acute GVHD. However, they only investigated the patients' skin, but did not examine other tissues for the presence of Th17 cells ${ }^{(24)}$.

The study by Ratajczak et al., 2011, comprises 96 biopsies in GVHD patients. They explored patients with gastrointestinal and skin GVHD, and the Th17/Treg ratio correlated with both clinical diagnosis and disease severity as assessed by pathologic grade. They concluded that Th17 in gastrointestinal and skin GVHD was not associated with severe tissue damage, but that the Th17/Treg ratio quantification in situ was a specific marker of human GVHD. The authors also reported the study limitations, inherent to studies in humans. They had only one time point biopsy from each patient, and it cannot exclude Th17 presence at the beginning of clinical GVHD manifestations $(28)$

Allografts from forty-one patients were analyzed for IL-17-producing T-cells in acute GVHD onset by Zhao et al., 2011. This group investigated patients who had undergone granulocyte colony-stimulating factor (G-CSF)-mobilized peripheral blood progenitor cells and G-CSF-primed bone marrow transplantation. The results indicate that patients who received higher doses of Th17 cells, G-CSF-primed bone marrow, or a higher dose of Tc17 cells in mobilized peripheral blood progenitor cells exhibited a higher incidence of acute $\mathrm{GVHD}^{(2)}$.

Serody and Hill, 2012, conclude in their review that although little is known of IL-17A contribution to GVHD, IL-17A generation is augmented by the use of
G-CSF-mobilized grafts, and that this is correlated with disease incidence ${ }^{(20)}$.

Finally, in reviewing literature Paczesny et al., 2010, bring to light the inevitability of robust computational development and mathematical tools to set all emerging experimental data into a multistage model that links intracellular molecular interactions with intercellular behavior to target organ systems ${ }^{(2)}$.

\section{CONCLUSIONS}

Even with controversies, there is evidence in the experimental and clinical studies reviewed here that Th17 is implicated in acute and chronic GVHD physiopathology. Notwithstanding, the detailed Th17 contribution to GVHD or to the Th17/Ireg ratio was not totally revealed by these several studies. These questions should be further investigated, which may contribute to the development of new therapies in this field.

\section{ACKNOWLEDGEMENTS}

We are grateful to The State of São Paulo Research Foundation (FAPESP) and to the Sociedade Beneficente Israelita Brasileira Albert Einstein (SBIBAE) for their support.

\section{REFERENCES}

1. Hill GR, Crawford JM, Cooke KJ, Brinson YS, Pan L, Ferrara JL. Total body inradiation and acute graft versus host disease. The role of gastrointestinal damage and inflammatory cytokines. Blood. 1997;90/8):3204-13.

2. Vanaudenaerde BM, Dupont LJ, Wuyts WA, Verbeken EK, Meyts I, Bulens $\mathrm{DM}$, et al. The role of interleukin-17 during acute rejection after lung transplantation. Eur Respir J. 2006;27(4):779-87

3. Yao Z, Painter SL, Fanslow WC, Ulich D, Macduff BM, Spriggs MK, et al. Cutting edge: Human L-17: A novel cytokine derived from T-cels. J Immunol. 1995; 155/12):5483-6.

4. Yao Z, Fanslow WC, Seldin MF, Rousseau A-M, Painter SL, Comeau MR, et al. Herpesvirus saimin encodes a new cytokine, IL-17, which binds to a novel cytokine receptor. Immunity. 1995-3(6):811-821.

5. Yao Z, Spriggs MK, Derry JMJ, Strockbine L, Park LS, VandenBos T, et al. Molecular characterization of the human interleukin-17 receptoc. Cytokine. 1999;9111:794-800

6. Ye P. Rodiguez FH, Kanaly S, Stocking KL, Schurr J, Schwarzenberger P, et al. Requirement of interleukin 17 receptor signaling for lung $\mathrm{CXC}$ chemokine and granulocyte colony-stimulating factor expression, neutrophil recruitment, and host defense. J Ex Med. 2001;194/4)-519-27.

7. Ye P, Garvey PB, Zhang P, Nelson S, Bagby G, Summer WR, et al. Interleukin-17 and lung host defense against Klebsiella pneumoniae infection. Am J Respir Cell Mol Biol. 2001;25(3):335-40.

8. Weaver CT, Hatton RD, Mangan PR, Harrington LE. IL-17 family cytokines and the expanding diversity of effector T-cell lineages. Annu Rev Immunol. 2007; 25:821-52.

9. Marti L, Golmia R, Golmia AP, Paes AT, Gulhen DD, Moreira-Fllho CA, et al. Alterations in cytokine profile and dendritic cells subsets in peripheral blood of rheumatoid arthritis patients before and after biologic therapy. Ann N Y Acad Sci. 2009;1173:334-42 
10. Loong CC, Hsieh HG, Lui WY, Chen A, Lin CY. Evidence for the early involvement of interleukin 17 in human and experimental renal alograft rejection.J Pathol. 2002;197/3):322-32.

11. Infante-Duarte $\mathrm{C}$, Horton HF, Byme MC, Kamradt T. Microbial lipopeptides induce the production of IL-17 in Th cells. J Immunol. 2000;165[11/:6107-15.

12. Ghlard $N$, Ouyang $W$. Targeting the development and effector functions of TH17 cells. Semin Immunol. 2007;19(6):383-93.

13. Chen X, Vodanovic-Jankovic S, Johnson B, Keller M, Komorowski R, Drobyskj Wh. Absence of regulatory T-cell control of TH1 and TH17 cells is responsible for the autoimmune-mediated pathology in chronic graft-versus-host disease. Blood. 2007;110|10|:3804-13.

14. Mauermann N, Burian J, von Garnier C, Dimhofer S, Germano D, Schuett C, et al. Interferon-gamma regulates idiopathic pneumonia syndrome, Th17+CD4+ T-cell-mediated grat-versus-host disease. Am J Respir Crit Care Med. 2008,178(4):379-88.

15. Yi T, Zhao D, Lin CL, Zhang C, Chen Y, Todorov L, et al. Absence of donor Th17 leads to augmented Th1 differentiation and exacerbated acute graft-versushost disease. Blood. 2008;112(5):2101-10.

16. Kappel LW, Goldberg GL, King CG, Suh DY, Smith OM, Ligh C, et al. IL-17 contributes to CD4-mediated graft-versus-host disease. Blood. 2009:113(4) 945-52.

17. Cartson MJ, West ML, Coghill JM, Panoskaltsis-Mortari A, Blazar BR, Serody JS. In vitro-differentiated Th17 cels mediate lethal acute graft-versus-host disease with severe cutaneous and pulmonary pathologic manifestations. Blood. 2009;113/6):1365-74.

18. Yi T, Chen Y, Wang L, Du G, Huang D, Zhao D, et al. Reciprocal differentiation and tissue-specific pathogenesis of Th1, Th2, and Th17 cells in gratt-versushost disease. Blood. 2009;114(14):3101-12.

19. Bucher C, Koch L, Voctenhuber C, Goren E, Munger M, Panoskaltsis-Mortari A, et al. IL-21 blockade reduces graft-versus-host disease mortaity by supporting inducible T regulatory cel generation. Blood. 2009;114(26):5375-84.

20. Thompson JS, Chu Y, Glass JF, Brown SA. Absence of IL-23p19 in donor alogeneic cells reduces mortality from acute GVHD. Bone Marrow Transplant. $2010,45(4): 712-22$

21. Iclozan C, Yu Y, Lu C, Lang Y, Yi T, Anasetti C, et al. Thelper 17 cells are sufficient but not necessary to induce acute graft-versus-host disease. Biol Blood Marow Transplant. 2010:16(2):170-8.

22. Radojcic V, Pletneva MA, Yen HR, lvcevic S, Panoskaltsis-Mortari A, Giliam AC, et al. STAT3 signaling in CD4+ T-cells is critical for the pathogenesis of chronic sclerodermatous graft-versus-host disease in a murine model. Immunol. 2010;184(2):764-74.

23. Dlubek D, Turlej E, Sedzimirska M, Lange J, Lange A. Interleukin-17-producing cels increase among CD4+ lymphocytes before overt manifestation of acute graft-versus-host disease. Transplant Proc. 2010;42(8):3277-9.

24. Broady R, Yu J, Chow V, Tantiworawit A, Kang C, Berg K, et al. GVHD is associated with the expansion of tissue-localized Th1 and not Th17 cells. Blood. 2010;116(25):5748-51

25. Brandon JA, Jennings $C D$, Kaplan AM, Bryson JS. Development of a $T(H) 17$ immune response during the induction of murine syngeneic graft-versus-host disease. Optokine. 2010,52(3):265-73.

26. Engelhardt BG, Crowe JE Jc. Homing in on acute graft vs host disease: tissue-specific T regulatory and Th17 cells. Jr.Curr Top Microbiol Immunol. 2010;341:121-46.

27. Paczesny S, Hanauer D, Sun $Y$, Reddy P. New perspectives on the biology of acute GVHD. Bone Marrow Transplant. 2010;45(1):1-11.

28. Ratajczak $P$, Janin A, Peffault de Latour $R$, Leboeuf C, Desveaux A, Kewanfar $\mathrm{K}$, et al. Th17/Treg ratio in human graft-versus-host disease. Blood. 2010; 116/7):-1165-71.

29. Zhas XY, Xu LL, Lu SY, Huang XJ. L-17-producing T-cels contribute to acute graft-versus-host disease in patients undergoing non-manipulated blood and marrow transplantation. Eur J Immunol. 2011;41 (2):514-26.

30. Ma HH, Zegler J, Li C, Sepulveda A, Bedeir A, Grandis J, Lentzsch S, Mapara MY. Sequential activation of inflammatory signaling pathways during graftversus-host disease (GVHD): early role for STAT1 and STAT3. Cell Immunol. 2011;268/1):37-46.

31. Noguchi D, Wakita D, Ohkuri T, Tajima M, Chamoto K, Kitamura H, et al. Blockade of IL-6-signaling inhibits the pathogenesis of $\mathrm{CD} 4+\mathrm{T}$-cell-mediated lethal graft-versus-host reaction against minor histocompatibilty antigen Immunol Lett. 2011;136(2):146-55.

32. Yu Y, Wang D, Luu C, Kaosaard K, Semple K, Anasetti C, et al. Prevention of GVHD while sparing GVL effect by targeting Th1 and Th17 transcription factor T-bet and ROAYt. Blood. 2011;118/18):5011-20.

33. Teshima T. Th1 and Th17 join forces for acute $W / H D$. Elood. 2011;118/18):4765-7.

34. Teshima T, Maeda Y, Ozaki K. Regulatory T-cells and IL-17-producing cels in graft-versus-host disease. Immunotherapy. 2011;3(7):833-52.

35. Hanash AM, Kappel LW, Yim NL, Nejat RA, Goldberg GL, Smith OM, et al. Abrogation of donor T-cell IL-21 signaling leads to tissue-specific modulation of immunity and separation of GVHD from GVL. Blood. 2011;118(2) 446-55.

35. Yang J, Fan H, Hao J, Ren Y, Chen L, L $G_{2}$, et al. Amelioration of acute gratversus-host disease by adoptive transfer of ex vivo expanded human cord blood CD4 + CD25 + fork head box protein $3+$ regulatory T-cells is associated with the polarization of Treg/Th17 balance in a mouse model. Transfusion. 2012;52(6):1333-47

37. Gowdy KM, Nugent JL, Martinu T, Potts E, Snyder LD, Foster WM, et al. Protective role of T-bet and Th1 cytckines in pulmonary graft-versus-host disease and peribronchiolar fibrosis. Am J Respir Cell Mol Biol. 2012 46(2):249-56.

38. Nishimori H, Maeda Y, Teshima T, Sugivama H, Kobayashi K, Yamasuji Y, et al, Tanimoto M. Synthetic retinoid AmBO ameliorates chronic graft-versus-host disease by down-regulating Th1 and Th17. Blood. 2012;119(1):285-95.

39. Pan B, Zeng L. Cheng H. Song G, Chen C, Zhang Y, et al. Altered balance between Th1 and Th17 cells in circulation is an indicator for the severity of murine acute GVHD. Immunol Lett. 2012;142(1-2):48-54.

40. Serody JS, Hill GR. The IL-17 dfferentiation pathway and its role in transplant outcome. Biol Blood Marrow Transplant. 2012;18(1 Suppl):S56-61. 


\title{
9.4 ARTIGo SUBMETIDO
}

Título: IL-7 is involved in MSCs-driven apoptosis inhibition Revista: Biology of Blood and Marrow Transplantation

\author{
Elsevier Editorial System(tm) for Biology of \\ Blood and Marrow Transplantation \\ Manuscript Draft
}

Manuscript Number:

Title: IL-7 is involved in MSCs-driven apoptosis inhibition

Article Type: Full Length Article

Reywords: mesenchymal stem cell

lymphocytes

apoptosis

proliferation

Corresponding Author: Dr. Luciana C Marti, PhD

Corresponding Author's Institution: Hospital Israelita Albert Einstein

First Author: Marilia Normanton

Order of Authors: Marilia Normanton; Heliene Alvarenga; Nelson Hamerschlak, MD, PhD; Andreza A Ribeiro, MD, PhD; Andrea T Kondo, MD; Luiz V Rizzo, MD, PhD; Luciana C Marti, PhD

Abstract: Since 2004, when a cases report describing the use of a mesenchymal stem cells (MSCs) infusion as a therapy for GVHD after bone marrow transplantation, a new perspective in MSC function emerged. Since then MSCs immunomodulatory potential became the target of several studies. Although great progress has been made in our understanding of MSCs, their effect on $T$ cell remains obscure. Our study has confirmed the already described effect of MSCs on lymphocytes proliferation and survival. We also show that the impairment of lymphocyte proliferation and apoptosis is contact-independent and occurs in a prostaglandinindependent manner. A potential correlation between IL-7 and MSCs effect is suggested, as we show an increase in IL-7 receptors (CD127) on lymphocyte membrane in MSC presence. Additionally, blocking IL-7 in cocultures increased apoptosis. We also found that during Th17 differentiation in vitro, MSCs presence leads to Th17 cells with reduced capacity of IL-17 secretion, regardless of having several proinflammatory cytokines in culture. We did not confirm an increment of Treg in these cultures, but a reduced percentage of IL-17 secreting cells was observed, suggesting that the ratio between anti and pro-inflammatory cells changed. This changed ratio is very important to GvHD therapy and links MSCs to an anti-inflammatory role. Taken together, our finds provide important preliminary results on the lymphocyte pathway modulated by MSCs and may contribute for developing novel treatments and therapeutic targets for GvHD and other autoimmune diseases. 
Dear Editor,

We would like to submit an article entitled "IL-7 is involved in MSCs-driven apoptosis inhibition" as a regular manuscript to this Journal.

Since the first report in the literature that mesenchymal stem cells (MSCs) have immunemodulatory potential, they became the target of several studies.

There are some debates about the MSCs modulatory mechanism, but most articles from humans or animal models show a similar effect on lymphocyte proliferation inhibition. Some authors also describe MSCs anti-apoptotic effect on lymphocytes. Therefore, the aim of this study was to confirm data on lymphocytes proliferation and cytokine secretion when in contact with MSCs, evaluate MSCs effect on activated lymphocyte cell death in vitro, and to investigate whether prostaglandins and IL7 play a role in these cells signaling pathway.

Taken together, this article shows important preliminary results on the lymphocyte pathway modulated by MSCs. We also suggest that survival signals driven by IL-7 cytokine may play a prominent role on the apoptosis process. Our findings pave the way to a better understanding on how MSC act on lymphocytes and may contribute for further applications of these powerful therapeutic cells.

Furthermore, understanding how to manipulate MSCs ex vivo can be considered instrumental to progress in cell therapy. We endeavored to present our data with highest clarity and expect that our article will be acceptable for publication on Biology of Blood and Marrow Transplantation.

Thank you

Sincerely,

Luciana C Marti and co-authors 
Date: $03 / 01 / 2014$

Robert Korngold, Ph.D.

Editor-in-Chief

Biology of Blood and Marrow Transplantation

Hackensack University Medical Center

30 Prospect Avenue / Jurist Research Bldg

Hackensack, New Jersey 07601

Fax: 201-336-8696

Dear Dr. Korngold,

We are submitting a manuscript entitled

IL7 is involved in MSCs-driven apoptosis inhibition

to BBMT for publication as original full length article

We, the undersigned, declare that this manuscript is original and has not been published before and is not currently being considered for publication elsewhere.

We confirm that the manuscript has been read and approved by all named authors and that there are no other persons who satisfied the criteria for authorship but are not listed. We further confirm that the order of authors listed in the manuscript has been approved by all of us.

We understand that the Corresponding Author is the sole contact for the editorial process. He/She is responsible for communicating with the other authors about progress, submissions of revision, and final approval of proofs.

\section{List of authors and signatures:}

\section{Marilia Normanton}

\section{Heliene Alvarenga}

\section{Nelson Hamerschlak}

\section{Andreza Alice F Ribeiro}

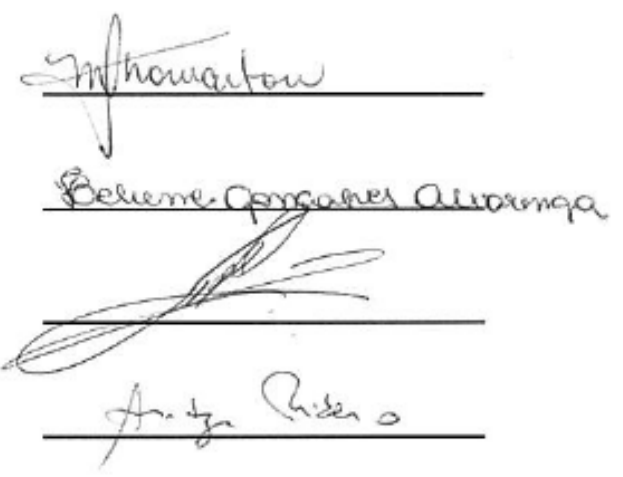

\section{Andrea Tiemi Kondo}

\section{Luiz Vicente Rizzo}

7. Luciana C Marti

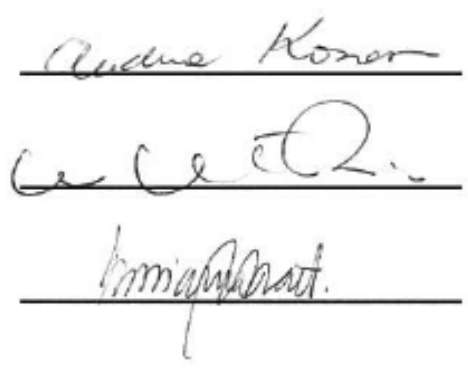




\section{IL7 is involved in MSCs-driven apoptosis inhibition}

Marilia Normanton* $\S$, Heliene Alvarenga* $\S$, Nelson Hamershlack $¥$, Andreza Ribeiro $\dagger$, Andrea Kondo $\neq$, Vicente Rizzo*, Luciana Cavalheiro Marti *§•

*Hospital Israelita Albert Einstein - Instituto Israelita de Ensino e Pesquisa Albert Einstein (IIEP-AE).

¥Hospital Israelita Albert Einstein - Bone Marrow Transplant Program.

$\dagger$ Hospital Israelita Albert Einstein - Oncology Department.

$\ddagger$ †ospital Israelita Albert Einstein - Blood Bank Department.

§Programa de Pós-graduação em Alergia e Imunopatologia - Faculdade de Medicina da Universidade de São P. (FMUSP).

Running/Short title:

Key words: mesenchymal stem cell, lymphocytes, apoptosis and proliferation.

- Corresponding author:

Luciana C Marti

Hospital Israelita Albert Einstein - Centro de Pesquisa Experimental

Av. Albert Einstein, 627

Morumbi

São Paulo - SP Brazil

05652-000 


\section{Abstract}

Since 2004, when a cases report describing the use of a mesenchymal stem cells (MSCs) infusion as a therapy for GVHD after bone marrow transplantation, a new perspective in MSC function emerged. Since then MSCs immunomodulatory potential became the target of several studies. Although great progress has been made in our understanding of MSCs, their effect on T cell remains obscure. Our study has confirmed the already described effect of MSCs on lymphocytes proliferation and survival. We also show that the impairment of lymphocyte proliferation and apoptosis is contact-independent and occurs in a prostaglandin-independent manner. A potential correlation between IL-7 and MSCs effect is suggested, as we show an increase in IL-7 receptors (CD127) on lymphocyte membrane in MSC presence. Additionally, blocking IL-7 in co-cultures increased apoptosis. We also found that during Th17 differentiation in vitro, MSCs presence leads to Th17 cells with reduced capacity of IL-17 secretion, regardless of having several pro-inflammatory cytokines in culture. We did not confirm an increment of Treg in these cultures, but a reduced percentage of $\mathrm{IL}-17$ secreting cells was observed, suggesting that the ratio between anti and pro-inflammatory cells changed. This changed ratio is very important to GvHD therapy and links MSCs to an anti-inflammatory role. Taken together, our finds provide important preliminary results on the lymphocyte pathway modulated by MSCs and may contribute for developing novel treatments and therapeutic targets for GvHD and other autoimmune diseases. 


\section{INTRODUCTION}

Since 2004, Le Blanc et al. brought to light a new perspective about mesenchymal stem cells (MSCs), when published a severe graft versus host disease (GVHD) case report. After receiving MSCs infusions, a GVHD patient presented a significant clinical improvement without showing adverse reaction [1]. Since then the MSCs immunemodulatory potential became the target of several studies.

Mesenchymal stem cells (MSCs) also known as mesenchymal stromal cells, are adult non-hematopoietic stem cells with self-renew and differentiation capacity, which were first described as plastic adherent cells with fibroblastic shape $[2,3]$. In 2006, the International Society for Cellular Therapy proposed a set of phenotypic and functional criteria to define MSCs [4]. MSCs isolation was demonstrated possible from a variety of sources, such as bone marrow, adipose tissue, fetal liver, muscle, umbilical cord blood and dental pulp [5-7]. However, the bone marrow still is the most studied source, mainly because it is the source already used in clinical tests for cell therapy.

There are some debate about the MSCs modulatory mechanism, which some authors have reported being through indoelamine-2,3-oxigenase (IDO) up-regulation through secretion of prostaglandins or IFN- $\gamma$ in humans or through oxidative stress in animal models. Even though, MSCs immunemodulation occurs by different cell signaling pathways in humans and animal models. Mouse, monkey and human MSCs seem to have similar effects on lymphocyte proliferation inhibition $[8,9]$.

When in presence of MSCs, T cells response, stimulated by alloantigen [10 - 12], antigenic peptides [13], mitogens $[10,14]$ and by anti $\mathrm{CD} 3 / \mathrm{CD} 28$ antibodies, has been tested and the results suggest that the MSCs immunemodulatory effect is not specific and takes place through lymphocyte proliferation inhibition.

Although great progress has been made in our understanding of MSCs, their effect on T cell remains obscure. Besides belonging to the hematopoietic stem cell niche and to act on differentiation and stem state maintenance. MSCs most likely affect neighbor cells survival, either through a contact dependent manner or by secreting soluble molecules $[15,16]$.

Recently, a study demonstrated that MSCs secrete multiple cytokines and besides promoting angiogenesis they have contrasting effects on chemotaxis and apoptosis [17]. Furthermore, cytokines such as Interleukin-7, previously described as a stromal cell secreted cytokine, has also been described as critical for homeostatic proliferation and survival of naïve $T$ cells, although its mechanism has not been fully described $[18,19]$.

The use of phytohemagglutinin (PHA), a mitogen that leads these cells to a very robust proliferation and activation, is commonly applied to stimulate lymphocyte proliferation. Following this rational, MSCs diminish lymphocyte proliferation and cytokines secretion while they also act on cell death. Therefore, the aim of this study was to confirm data on lymphocytes proliferation and cytokine secretion when in contact with MSCs and evaluate MSCs effect on activated lymphocyte cell death in vitro, and to investigate whether prostaglandins and IL7 play a role in these cells signaling pathway. Our findings pave the way to a better understanding on how MSC act on lymphocytes and may contribute for further applications of these powerful therapeutic cells. 


\section{MATERIALS AND METHOD}

\section{Cells isolation}

MSCs were obtained from bone marrow collection filters as previously described by Deus et al, and lymphocytes were obtained from health donor's peripheral blood following the signing of informed consent (Approved by Hospital Albert Einstein Ethical Committee -10/1412) [20] .

Bone marrow collection filters were washed with 20mL DMEM-LG (Gibco - Carlsbad - CA); the obtained cells were diluted at the proportion of 1:3 with Phosphate Buffered Saline (PBS) (Gibco - Carlsbad - CA). Next, cells were transferred to a $50 \mathrm{~mL}$ conical tube containing $20 \mathrm{~mL}$ of Ficoll-Paque 1.077 density (GE Healthcare, United Kingdom) and centrifuged by 30 minutes at $500 \mathrm{~g}$ and $22^{\circ} \mathrm{C}$. Then, suspended cells were transferred to another tube, centrifuged again for 5 minutes at $500 \mathrm{~g}$ and $22^{\circ} \mathrm{C}$. The supernatant was discarded and cells resuspended with DMEM-LG (Gibco $\&$, Carlsbad, CA), supplemented with 10\% FBS (Gibco $\&$, Carlsbad, CA), $1 \%$ antibioticantimycotic (Gibcoß, Carlsbad, CA), $2 \mathrm{mM} \mathrm{L}$-glutamin (Gibco $\$$, Carlsbad, CA), in order to achieve $1 \times 10^{5} \mathrm{cells} / \mathrm{mL}$. Next, cells $(5 \mathrm{~mL})$ were cultivated into $25 \mathrm{~cm}^{2}$ flasks and maintained in humidified $5 \% \mathrm{CO} 2$ incubators at $37^{\circ} \mathrm{C}$ to favor the attachment of the MSCs to the flask bottom. MSCs were characterized by flow cytometry and differentiated in three cell lineages such as osteocytes, chondrocytes and adipocytes (data not shown) as previously published [20].

\section{Cell culture}

MSCs were transferred to a 6-well plate and maintained in culture until reaching $80 \%$ confluence.

In order to evaluate the effect of those cells on lymphocytes, lymphomononuclear cells were monocyte depleted. Next, Lymphocytes were suspended in Xvivo15 (Cambrex, Walkersville, MD), supplemented with $1 \%$ human pooled serum $\mathrm{AB}$ (Life Technologies, Carlsbad, $\mathrm{CA}$ ) and $1 \%$ antibiotic-antimycotic (Gibco, Carlsbad, $\mathrm{CA}$ ) then stimulated with $5 \mu \mathrm{g}$ of phytohemagglutinin (PHA) $/ 1 \times 10^{6}$ cells. Approximately $1 \times 10^{6}$ lymphocytes were added to MSCs and co-cultivated for 24, 48 and/or 72 hours. Lymphocytes were also co-cultivated with MSCs separated by transwell $0.2 \mu \mathrm{m}$ - anopore membrane (Nunc Kamstrup, Denamark).

\section{Cell culture with Indomethacin}

Cells in co-culture were also treated with different concentrations of Indomethacin $(5,25,50$ and $100 \mathrm{ng})$ in order to verify if this anti-inflammatory drug would abrogate the anti-apoptotic and/or anti-proliferative effects of MSCs.

\section{Cell culture with Interleukin 7 and Interleukin 7 block}

Cells in co-culture were also treated with different concentrations of IL-7 antibody (10 and 20ul) (eBiosciences), in order to verify if this cytokine block would affect the anti-apoptotic and/or anti-proliferative effects of MSCs. Lymphocytes PHA stimulated without co-cultivation were also treated with two different concentrations of IL-7 (10 and 20ng) (R\&D systems) in order to verify if this cytokine would affect the anti-apoptotic and/or anti-proliferative effect of MSCs. 


\section{Thl7 differentiation}

Naive T lymphocytes derived from health volunteers peripheral blood, (CD4, CD45RA), were separated by indirect cell targeting by using Naive $\mathrm{CD}^{+} \mathrm{T}$ Cell Isolation Kit II (Miltenyi biotec, Gladbach, Germany) according manufactures instruction. Isolated cells were stimulated with CD3/CD28 microspheres (Life Technologies, Carlsbad, CA), and cultured for 5 days, treated with $10 \mathrm{ng} / \mathrm{mL}$ de IL1 $\beta$, IL6, IL23 and $5 \mathrm{ng} / \mathrm{mL}$ of TGF $\beta$ (R\&D Systems, Minneapolis, MN) and with anti-IFNg (Clone: 25723.11), anti-IL2 (Clone:5344.111). During naïve T cells in differentiation to Th17 pattern were cultivated in presence or absence of MSCs.

\section{T-cell apoptosis and proliferation assay}

Apoptosis and proliferation were measured by flow cytometric assays. Lymphocytes were stained according to manufactures instructions, using two different combinations: First combination was Annexin V-FITC, propidium iodide-PI and CD3-APC (clone:HIT3a, BD Pharmingen, CA, San Diego) and second combination was KI-67-FTIC (clone: MOPC-21, BD Pharmingen, CA, San Diego), Caspase-3 activated-PE (clone: C92-605, BD Phanmingen, CA, San Diego), CD3-PerCP Cy5.5 (clone:SK7, BD Biosciences, CA, San Jose)CD4-APC (clone:RPA-T4, BD Pharmingen, CA, San Diego), using two distinct staining protocols.

Briefly, for testing apoptosis the lymphocytes were ressuspendend with Annexin V binding buffer (BD Biosciences, San Jose, CA) and stained for Annexin V, PI and CD3 for 15 minutes, the samples were acquired for flow cytometric analysis within 30 minutes after finishing incubation. For proliferation and apoptosis, staining for surface markers as CD3 and CD4 was performed and the cells were incubated for 30 minutes following fixation using BD FACS Lysing solution (BD Biosciences, San Jose, CA). Next, the cells were permeabilized using BD FACS Permeabilization solution 2 (BD Biosciences, San Jose, CA) and the intracellular staining was performed. At least 10,000 events were acquired by BD FACSARIA equipment (BD Biosciences, San Jose CA), and the results were analyzed by FACSDIVA and/or FlowJo software.

\section{Thl7 cell and regulatory $\mathrm{T}$ cell stain}

$\mathrm{T}$ cells in co-culture were characterized by flow cytometry assay and stained according to manufactures instruction Briefly, for Th17 cells, the staining for surface markersCD3-APC (clone:HIT3a, BD Pharmingen, CA, San Diego), CD4-APC-Cy7 (clone:SK3, BD Biosciences, CA, San Jose), CD45PerCP-Cy5.5 (clone:2D1, BD Biosciences, CA, San Jose) or CD3-PerCP-Cy5.5 (clone:SK7, BD Biosciences, CA, San Jose), CD4-APC (clone:RPA-T4, BD Pharmingen, CA, San Diego), CD8-PE (clone: RPA-T8, BD Pharmingen, CA, San Diego), CD45RA-FITC (clone:HI100, BD Pharmingen, CA, San Diego), CD45RO-PE (clone:UCHL1, BD Pharmingen, CA, San Diego), CCR5-FITC (clone:45502, R\&D System, MN, Minneapolis), CCR6-PE (clone:53103, R\&D System, MN, Minneapolis), was performed and cells were incubated for 30 minutes following fixation using BD FACS Lysing solution (BD Biosciences, San Jose, CA). Next, cells were permeabilized using BD FACS Permeabilization solution II (BD Biosciences, San Jose, CA), the intracellular staining was performed with (Tbet-PerCP-Cy5.5 (clone:4-46, BD Pharmingen, CA, San Diego), IL17A-FITC (clone:N49-653, BD Pharmingen, CA, San Diego), anti-IL17F-PE (clone:033-782, BD Pharmingen, CA, San Diego), RORyt-PE (clone: AFKJS-9, eBiosciences, CA, SanDiego) and IFN $\gamma$-FITC (clone:25723.11, BD Biosciences, CA, San Jose).

For Treg cells, staining for surface markers CD45-PE-Cy7 (clone:HI-30), CD3-APC-Cy7(clone:SK-7), CD4-FITC (clone:RPA-T4), CD25-APC (Clone:M-A251) and CD127-PercP-Cy5.5 (clone:HIL-7R-M21), was performed and cells were incubated for 30 minutes following fixation using Foxp3 staining Kit (BD Biosciences, San Jose, CA) 
and intracellular staining FoxP3-PE (clone:259D/C7). At least 10,000 events were acquired by BD FACSARIA equipment (BD Biosciences, San Jose CA), and the results were analyzed by FACSDIVA and/or FlowJo software.

\section{T-cell surface expression of CD127}

CD127 was measured by flow cytometric assays. Lymphocytes were stained according to manufacture instructions for CD3-FITC (clone:HIT3a), CD127-PercP-Cy5.5 (clone:HIL-7R-M21) and CD4-APC (clone:RPA-T4, BD Pharmingen, CA, San Diego).

Briefly, the staining for surface markers CD3, CD4 and CD127 was performed and cells were incubated for 30 minutes following fixation using BD FACS Lysing solution (BD Biosciences, San Jose, CA). At least 10,000 events were acquired by BD FACSARIA equipment (BD Biosciences, San Jose CA), and the results were analyzed by FACSDIVA and/or FlowJo software.

\section{Statistical Analysis}

GraphPad Prisma Program was used to perform the statistical analyses. Statistical significance was calculated by Student's $t$-test or One-Way/ANOVA for multiple comparisons in relation to a control sample; $p<0.05$ was considered significant. 


\section{RESULTS}

Mesenchymal stem cell presence reduces lymphocyte apoptosis and proliferation

In order to evaluate the MSC influence in lymphocytes activity, we first asses its effect on lymphocytes proliferation and apoptosis. Co-cultures of T cell (CD3+) PHA stimulated with MSC presented less early apoptosis determined by Annexin V expression and late apoptosis/necrosis determined by co-expression of Annexin V and Propidium Iodide, if compared to controls ( $\mathrm{T}$ cell (CD3+) PHA stimulated without MSC co-cultivation) (Figure 1).

After 24 hours, the differences between samples $(n=8)$ were not significant, however, after 48 hours of cocultivation the mean percentage of lymphocytes in initial apoptosis was lower $(9.1 \pm 2.8)$ than the controls $(12.7 \pm 2.0)$ (Figure 2A). The same was observed for late apoptosis/necrosis ( $\mathrm{n}=8$ ). After 48 hours of co-cultivation the mean percentage of lymphocytes in late apoptosis was lower $(28.0 \pm 13)$ than controls $(41.9 \pm 13)$ (Figure 2B)

Additionally, co-cultures of T cell (CD3+) PHA stimulated with MSC ( $\mathrm{n}=8)$ presented less proliferation than controls, as determined by KI-67 expression (Figure 3). After 72 hours of co-cultivation, the mean percentage of lymphocytes proliferating was lower $(22.63+13.65)$ than controls $(36.13+13.19)$ (Figure 4).

\section{Lymphocytes apoptosis/necrosis and proliferation downregulation is not contact-independent}

To evaluate if lymphocytes apoptosis/necrosis downregulation was contact-dependent, lymphocytes were cocultivated with MSC separated by transwell and compared to lymphocytes co-cultivation without transwell. We observed that the MSC anti-apoptotic effect was not contact dependent since the apoptosis was significantly reduced in both conditions (Figure 5A and B). Even though we observed that there is a more intense apoptosis reduction in MSC presence without the transwell, we could not find statistical difference between them. In addition, the same was true for proliferation. We observed that the MSC anti-proliferative effect was not contact dependent since proliferation was significantly reduced in both conditions (Figure 6).

Indomethacin potentiate the anti-apoptotic and anti-proliferative effects of MSC in a dose-dependent manner With the purpose of verify if an anti-inflammatory would impair or enhance the MSC effect in lymphocytes we use Indomethacin (IDT), a non-steroidal anti-inflammatory drug. IDT was used in different concentrations $(5,25,50$ and 100ng) in PHA stimulated lymphocytes co-cultivated with MSCs. We found that IDT enhanced the MSC antiapoptotic effect on lymphocytes in a dose dependent manner and decreased early and late apoptosis (Figure 7).

We also found that indomethacin enhanced the MSC anti-proliferative effect on lymphocytes (Figure 8) in a dose dependent manner and decreased proliferation according to the dose.

\section{MSC presence enhances the availability of $\mathrm{IL}-7 \alpha$ chain receptor (CD127) on lymphocytes}

We also observed that MSC enhances the availability of CD127 on lymphocytes, from $(37 \pm 10 \%)$ up to $(44 \pm 10 \%)$; indicating a potential role for $\mathbb{L}-7$ in the anti-apoptotic effects here observed (Figure 9).

A role for IL-7 in lymphocytes survival MSC driving

IL-7 blockage in lymphocytes MSC co-culture enhances significantly early apoptosis (Figure 10A) while IL-7 addition to the controls impair early and late apoptosis likely MSCs presence (Figure 10B), suggesting that IL7 play a role in apoptosis reduction MSC driven. 
NaÏve lymphocytes Thl7 differentiated in MSC presence secrete less IL-17

Since IL-17 has been reported to be important to inflammation, we also investigated if MSC presence would impact the Th17 differentiation. Consequently, besides less apoptosis and proliferation, lymphocytes during differentiation into Th17 pattern, in presence of MSC, secreted 50\% less IL-17 than controls (Figure 11).

\section{MSC presence during Thl7 differentiation did not enhanced the $T$ regulatory cell numbers}

Since has been described before that MSC favors Treg differentiation (Figure 12), we investigated if the numbers of Treg increased on co-cultures during Th17 differentiation, but we did not find significant differences between presence of MSC and the control (Figure 12).

\section{DISCUSSION}

Our study has confirmed the already described effect of MSCs on lymphocytes proliferation and survival. We also show that the impairment of lymphocyte proliferation and apoptosis is contact-independent and have occurred in a prostaglandin-independent manner. A potential correlation between $\mathrm{IL}-7$ and MSCs effect is suggested since we show the increase of IL-7 receptor (CD127) on lymphocyte membrane in MSC presence. Additionally, blocking IL7 in the co-cultures increase apoptosis. We also found that during Th17 differentiation 'in vitro', MSCs presence have led to Th17 cells with reduced capacity of IL-17 secretion, regardless of having several pro-inflammatory cytokines in culture. We did not confirm an increment of Treg in these cultures, but a reduced percentage of IL-17 secreting cells was observed, thus we can suggest that the ratio between anti and pro-inflammatory cells have changed. This changed ratio is very important to GvHD therapy [21], and links MSCs to an anti-inflammatory role (Figure 14)

We observed that both lymphocyte co-cultutured directly with MSCs and those separated by transwell show the anti-proliferation and anti-apoptosis responses, indicating that these effects are not contact-dependent but rather occur due to a soluble factor, which confirms previous findings described in the literature (Figures $5 \mathrm{~A}$ and $\mathrm{B}$ ). Di Nicola et al, have reported inhibition of PHA stimulated lymphocyte proliferation in a contact-independent manner of MSCs [10]. Later, Krampera et a1, also reported inhibition of CD3 stimulated lymphocytes that it was contactindependent of MSCs (Krampera et al, 2006). In addition, Kim and Hemati have reported that MSCs have the potential to alter macrophages phenotypes independently of contact with them [22].

Adding Indomethacin (IDT), a non-steroidal anti-inflammatory drug that inhibits cox-1 and 2 pathways, to the cultures revealed that the anti-proliferative and anti-apoptotic effects of MSCs on lymphocytes have occurred in a prostaglandin independent manner, which contrast with the previously mechanism described by Ramusson et al, who has described that in presence of monocytes, IDT-treated MSCs show an anti-proliferation inhibition on lymphocytes. The fact that our cultures were monocyte-depleted allows us to suggest that the anti-proliferative and anti-apoptotic effects observed are prostaglandin-independent. Conversely, Nemeth et al, has reported a prostaglandin effect on lymphocytes anti-proliferative responses MSC-driven in human sepsis via macrophages reprogramming. Our diverging results might be explained by absence of macrophages in our cultures [23, 24]. . A 
number of studies indicate that IDO has anti-proliferative and anti-apoptotic effects. However, while these studies suggest that these effects are prostaglandin-dependent, some authors, including our group, believe that not prostaglandin but other molecules such as IFN- $\gamma$ would be associated to these effects $[25,26]$.

IDO acts by depleting the environmental available tryptophan, which should lead cells to apoptosis. However, this was not what we observed, which agrees with other studies [27 - 29]. Therefore, the mechanism that inhibited apoptosis in our co-cultures is still unknown. Cytokines such as $I L-7$, a member of the $I L-2$ family, has been reported as a possible molecule involved in apoptosis intrinsic and extrinsic pathways, by raising levels of antiapoptotic proteins or inhibiting some pro-apoptotic proteins such as Bid, Bad or Bax. I1-7 was described as a cytokine produced by several cells subsets such as T-cells, NK cells, monocytes and stromal cells [30-32]

In fact, we found that IL-7 blockage in lymphocytes:MSC co-culture enhances significantly early apoptosis while addition of IL-7 to control cells impair early and late apoptosis. This inhibition effects was similar to what was observed in MSCs presence (Figure 10). Additionally, when we added IL-7 to MSCs-free cells we did not observe an increase in proliferation (data not shown). Supporting our findings, IL-7 has been described as maintaining the cell viability by repressing cell death factors and/or activating a life factor. Since, IL-7 did not affect T-cell proliferation, the anti-proliferative effect observed in lymphocytes:MSC co-cultures might have been a result of IDO activation or another mechanism triggered by cytokines such as IL6, IL-10 and/or TGF $\beta[31,33]$.

In co-cultures, we observed the differentiation into Th17 cells showing a reduced capacity of IL-17 secretion. We did not see Treg differentiation in our co-cultures. Ghannam et al, also reported a reduced differentiation of Th17 in MSCs presence, but to these authors, naîve cells would also be differentiating into a Treg phenotype. While we measured the amount of Treg cells considering the whole cell phenotype and FoxP3 protein expression, the group measured FoxP3 by mRNA expression, which might explain why they obtained different results [34]

Taken together, our finds provide important preliminary results on the lymphocyte pathway modulated by MSCs. Importantly we suggest that survival signals driven by IL-7 cytokine may play a prominent role on the apoptosis process. It remains unclear how IL-7 acts on CD3 T cells survival in our co-cultures and whether other molecules are involved with this process. Our findings pave the way to a better understanding on how MSCs act on lymphocytes and may contribute for developing novel treatments and therapeutic targets for GvHD and other autoimmune diseases.

\section{ACKNOWLEDGMENT}

We are thankful to FAPESP that have funded this project thought the grant number 2011/02027-4. We are also grateful to Hospital Israelita Albert Einstein for all the support received. 


\section{TABLES AND FIGURES}

Figure 1 - Graphic representation of gate strategy for lymphocytes stimulated with PHA. (A, C and E) Lymphocytes stimulated with PHA in absence of MSC and (B, D and F) Lymphocytes stimulated with PHA in presence of MSC. (A and B) Gate strategy of lymphocytes by the forward and scatter. (C and D) Gate on CD3 positive cells and (E) late apoptosis/necrosis (51.6\%) represented by cells that are double positive for PI/AnnexinV and the early apoptosis cells (27.6\%) represented by the single positive cell (AnnexinV). (F) Effect of MSC on lymphocytes apoptosis, result for late apoptosis/necrosis (20.4\%) and the early apoptosis cells (10.9\%).

Figure 2 - hMSCs presence reduces apoptosis in stimulated lymphocytes. (A) Early apoptosis in PHA stimulated lymphocytes co-cultivated (CD3/hMSC) or not (CD3) with MSCs. Note a significant reduction after $48 \mathrm{hs}$ of cultivation in MSC presence $(12.7 \pm 2.0 \%$ ) as compared to $(9.1 \pm 2.8 \%$ ). (B) Late apoptosis/necrosis in PHA lymphocytes stimulated in presence (CD3/hMSC) or not (CD3) of hMSCs. Note a significant reduction after $48 \mathrm{hs}$ of cultivation in MSC presence $\left(41.9 \pm 11 \%\right.$ ) as compared to $(28.0 \pm 13 \%)$. (n=8) ${ }^{*} \mathrm{p}<0.05$

Figure 3 - Gate strategy of proliferation of PHA lymphocytes. (A) Gate strategy of PHA lymphocytes stimulated for 48 hours by forward and scatter and (B) Gate selection of CD3 cells. The low bottom shows gate strategy for CD3 and Ki67 positive cells, (C) Proliferation (20,9\%) in absence of MSC (D) Proliferation (13.2\%) in presence of hMSCs.

Figure 4 - hMSCs reduces proliferation in stimulated lymphocytes. A significant reduction of proliferation of PHA stimulated lymphocytes (CD3:PHA) $(36.13 \pm 13.19 \%)$ assessed by expression of $\mathrm{KI}-67$ is noted in presence of MSC (CD3:hMSC) $(22.63 \pm 13.65 \%)$. (n=9) *p $<0.05$

Figure 5 - Apoptosis reduction of PHA stimulated lymphocytes in presence of hMSCs is contact independent. (A) and (B) show early apoptosis and the late apoptosis, respectively of stimulated lymphocytes (CD3/PHA) and cocultivated with hMSC (CD3/hMSCs) using a $0.2 \mathrm{um}$ transwell (CD3T/hMSCs) for 72 hours. (A) Note a significant reduction of early apoptosis in presence of MSC $(25.75 \pm 2.86 \%)$ if compared to control $(45.0 \pm 6.40 \%)$ and in presence of transwell $(32.0 \pm 3.53 \%$ ). (B) A significant reduction of late apoptosis of stimulated lymphocytes (46,65 $+3.26)$ is observed if compared to values obtained in presence of MSC $(25,25 \pm 4.98 \%)$ and transwell $(32.1 \pm$ $8.36 \%)$. (n=4) * $\mathrm{p}<0.05$.

Figure 6 - Proliferation reduction of PHA stimulated lymphocytes in presence of hMSCs is contact-dependent. Significant reduction of proliferation of lymphocytes assessed by expression of KI-67, when in presence of MSC (CD3:hMSC) $(17 \pm 6.63 \%)$ and with transwell (CD3:T:MSC) $(12.63 \pm 0.49 \%)$ if compared to control (CD3) $(36.9+4.61) .(n=3) * \mathrm{p}<0.05$

Figure 7 - Indomethacin enhances reduction of 48-hour PHA stimulated lymphocytes apoptosis in presence of hMSCs. (A) Early A ptosis of PHA lymphocytes (CD3) $(8.71 \pm 2.92 \%$ ) reduces in presence of hMSCs $(\mathrm{CD} 3 / \mathrm{hMSC})(6.81 \pm 1.48 \%)$ and in increasing doses of indomethacin as follow $5 \mathrm{ng}(5.10 \pm 0.72 \%), 25 \mathrm{ng}(4.43 \pm$ 
$2.04 \%), 50 \mathrm{ng}(3.58 \pm 1.27 \%)$ and $100 \mathrm{ng}(2.40 \pm 1.81 \%)$. In (B) no statistical significance in late/necrosis apoptosis was observed. $(n=4) * p<0.05$

Figure 8 - Indomethacin enhances reduction of 48-hour PHA stimulated lymphocytes proliferation in presence of hMSCs. Proliferation of control (CD3) $(16.97 \pm 6.95 \%)$ is significant reduced if compared with stimulated lymphocytes co-cutivated with MSCs, who received $25 \mathrm{ng}(19.42 \pm 8.63 \%)$, 50ng $(19.35 \pm 6.11 \%)$ e $100 \mathrm{ng}(19.60 \pm$ $1.90 \%$ ) increasing doses of indomethacin. $(n=4) * p<0.05$

Figure 9 - MSC presence enhances the availability of IL-7 receptor (CD127) on lymphocytes. Presence of CD127 in lymphocytes co-cultured with MSCs (CD3:hMSC) $(37 \pm 10 \%)$ and control (CD3) $(44+10 \%)(\mathrm{n}=5)$.

Figure 10 - Interleukin-7 effect in PHA stimulated lymphocytes is likely hMSCs presence in early and late apoptosis (A) Early apoptosis in PHA stimulated lymphocytes (CD3) is $34.7 \pm 7.05 \%$ and in presence of MSC is reduced(CD3:hMSC) $(24.6 \pm 5.11 \%)$ or stimulated lymphocytes plus interleukin-7 (CD:3IL-7) (29.12 \pm 6.4$)$, but no difference is noted if compared with MSCs co-cultivated cells plus IL-7 block agent (CD3:hMSC:IL-7B1) $(36.27 \pm 3.8 \%$ ). (B) Late apoptosis in PHA stimulated lymphocytes cells (CD3) is $38.55 \pm 1.76 \%$ and in presence of MSC is reduced (CD3:hMSCs) $(19.85 \pm 4.72 \%)$, in presence of IL-7 block agent (CD3:hMSC:IL-7Bl) $(26.97 \pm 2.12 \%)$ or when stimulated lymphocytes plus interleukin-7 (CD3:IL-7) $(21.52 \pm 3.65 \%)$. (n=4) $\left({ }^{*} \mathrm{p}<0.05\right)$.

Figure 11 - Graphic representation of gate strategy of lymphocytes cytokines production. (A) Gated population of stimulated lymphocytes by scatter and CD45 (B) Gate on CD3 positive population (35.9\%) (C) Gate strategy of double positive cells for RORyt and IL-17A in absence of MSC (31.1\%) and (D) (16.6\%) in presence of MSC.

Figure 12 - Graphic representation of gate strategy of regulatory $T$ cells. In (A) gate strategy of stimulated lymphocytes by scatter and CD45 (B) Gate on CD3 positive population (87.5\%) (C) Gate strategy of double positive cells for $\mathrm{CD} 3$ and CD4 (78.6\%), (D) Gate strategy in positive cells for CD25 and low expression for CD127 (20.8\%) and in (E) gate strategy of double positive population for CD3 and FoxP3 expression (93.5\%).

Figure 13 - Presence of hMSCs do not enhanced switch of naïve differentiated Th17 cells into regulatory T cells There is no significant differences between means of acquired events of regulatory T cells (Treg) (422events) in absence of hMSC if compared to control (Teg:hMSC) (408 events).

Figure 14 - Schematic representation of MSC interaction with lymphocytes (A) Th1 lymphocytes secreting INF-y that will activate and enhance IDO pathway on MSCs (B) As IDO activation consequence there are tryptophan depletion from the environment leading to down regulation in lymphocytes activation and proliferation (C) MSC IL-7 secretion will lead lymphocytes to survive without interfering with proliferation (D) For unknown reasons MSC will lead to a down regulation in IL-17 secretion by T lymphocytes altering the environmental ratio between Th17 IL17 secreting cells and T regulatory cells. 
Figure 1
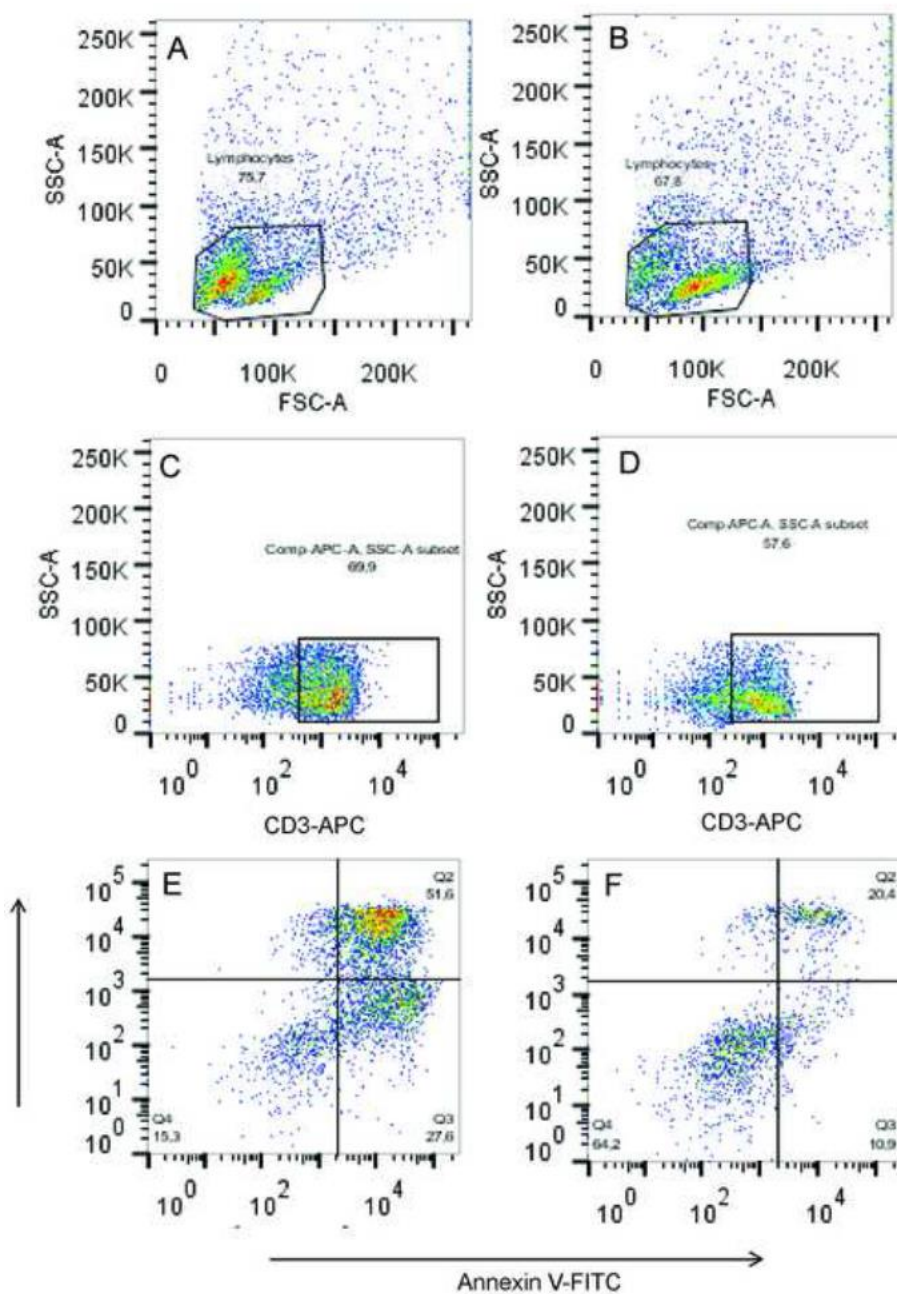

FiguRE 2

A

Early Apoptosis

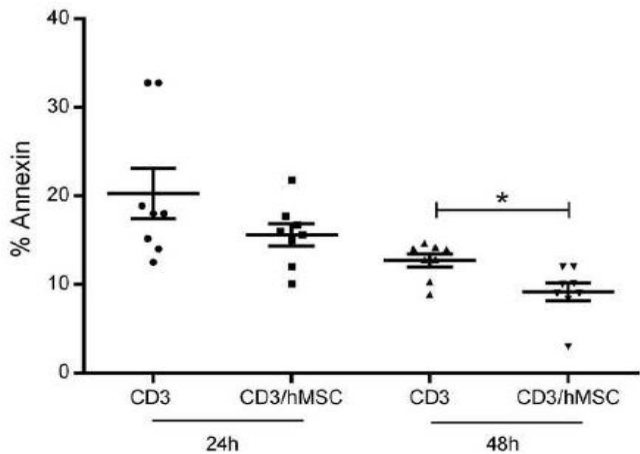

B Late Apoptosis/Necrosis

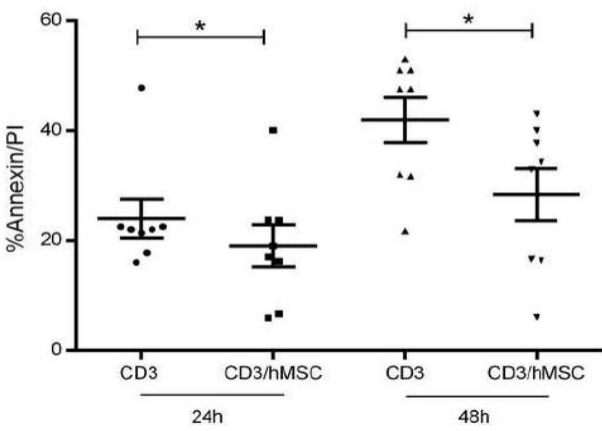


FIGURE 3
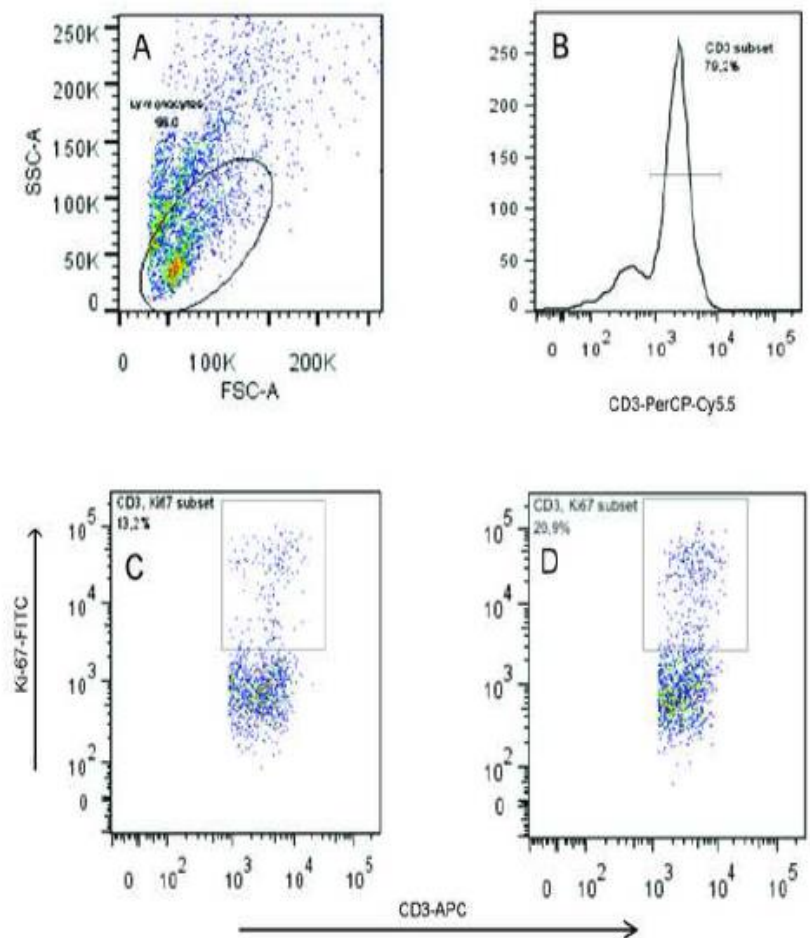

FIGURE 4

CD3 Proliferation

(72h)

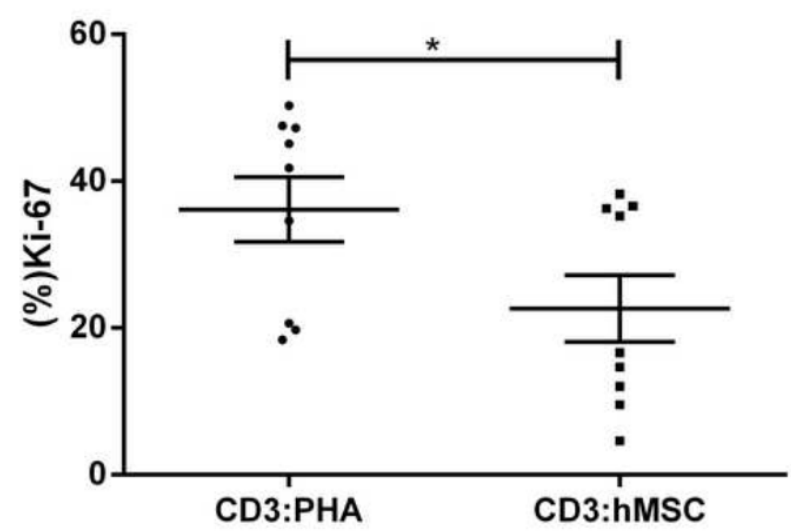




\section{FIGURE5}
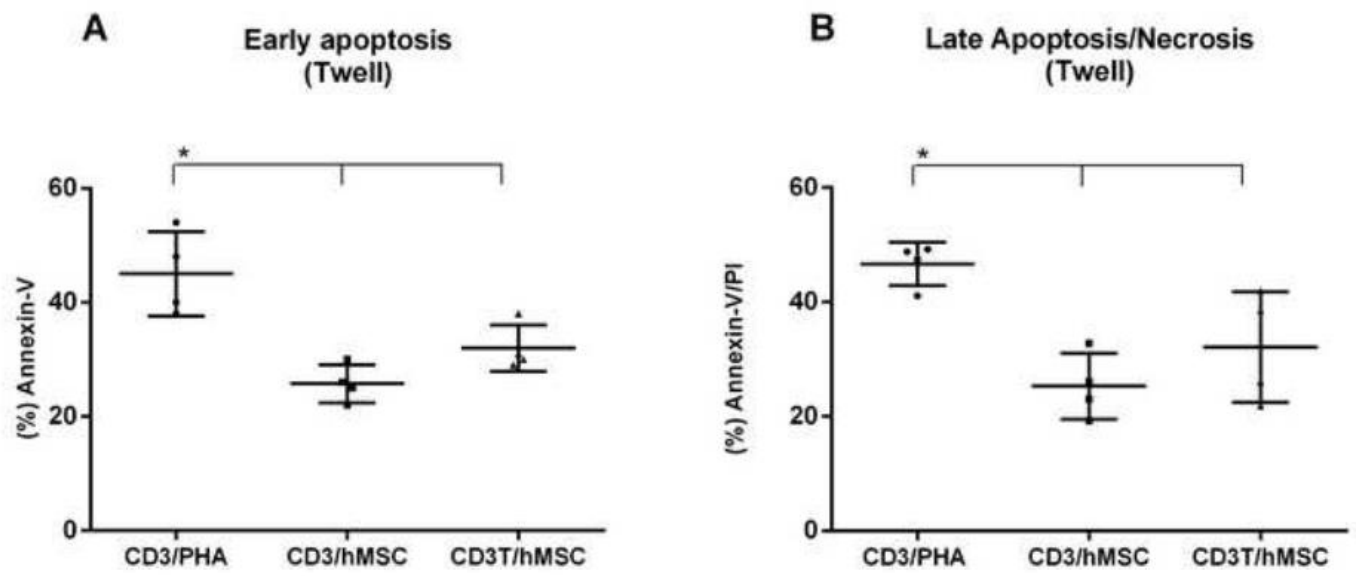

\section{FIGURE 6}

Proliferation

(Twell)

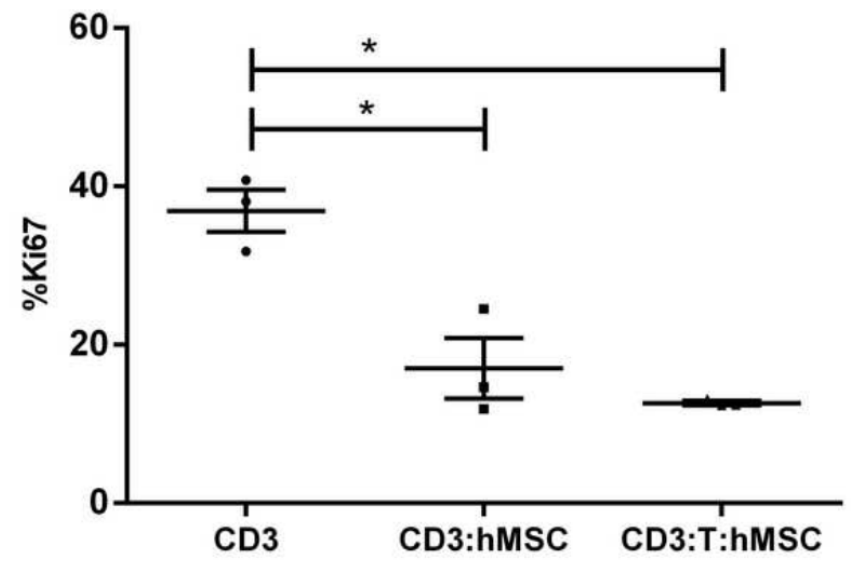


FIGURE 7

A Early Apoptosis

A

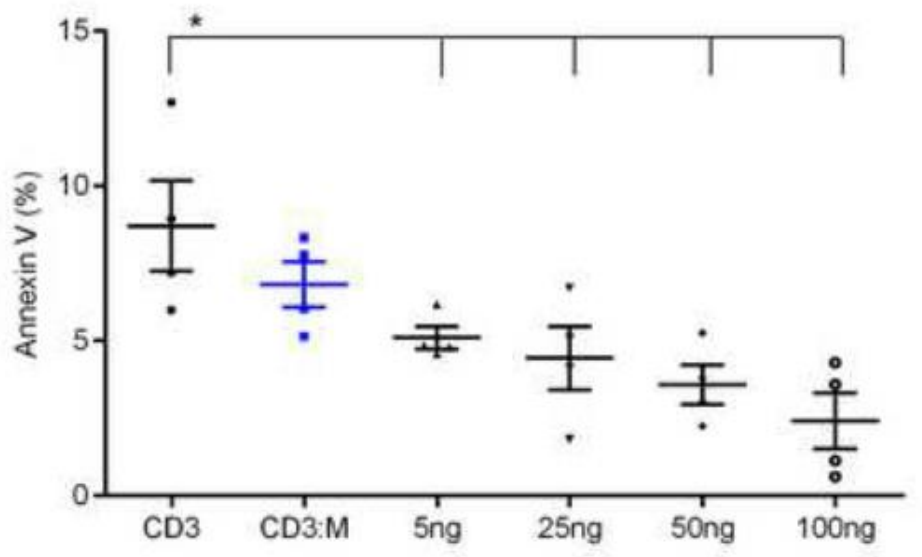

B

Late Apoptosis/Necrosis

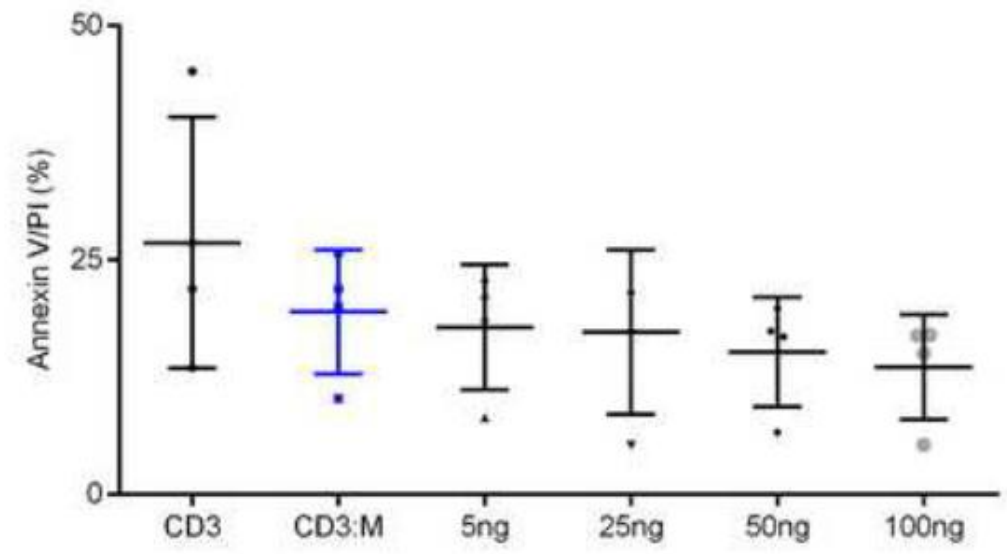


FIGURE 8

Proliferation

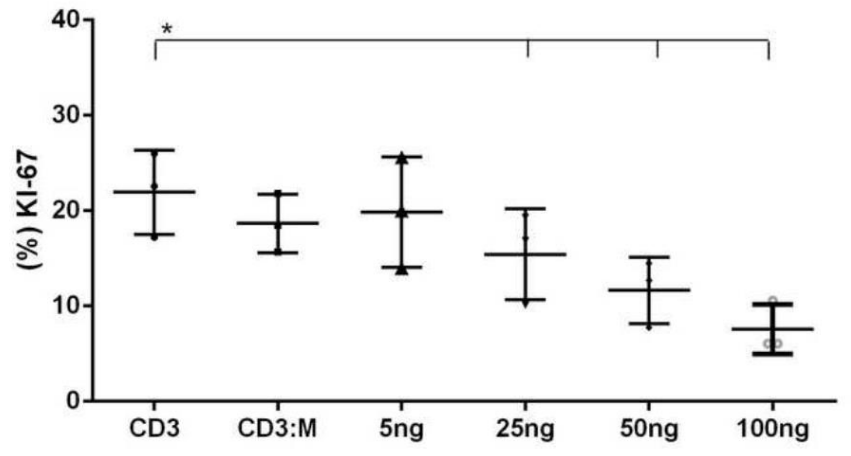

FIGURE 9

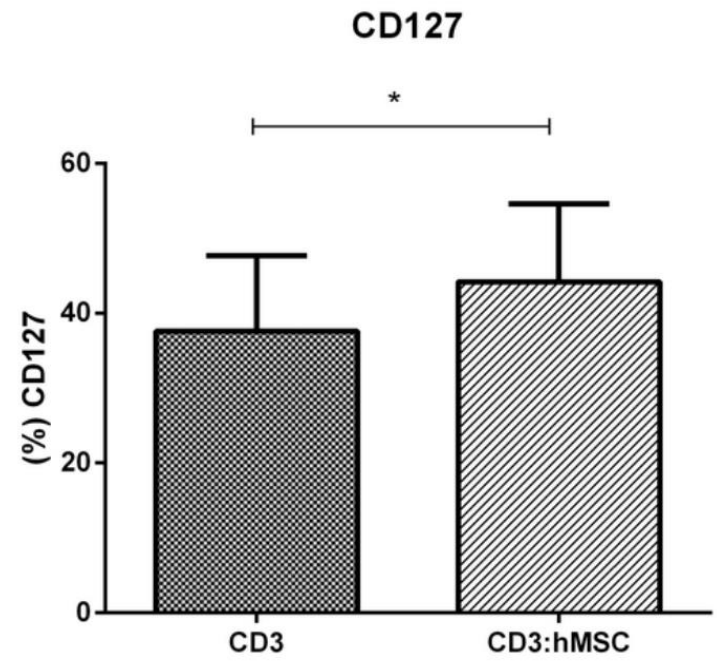


FIGURE 10

A

Early Apoptosis

(IL-7)

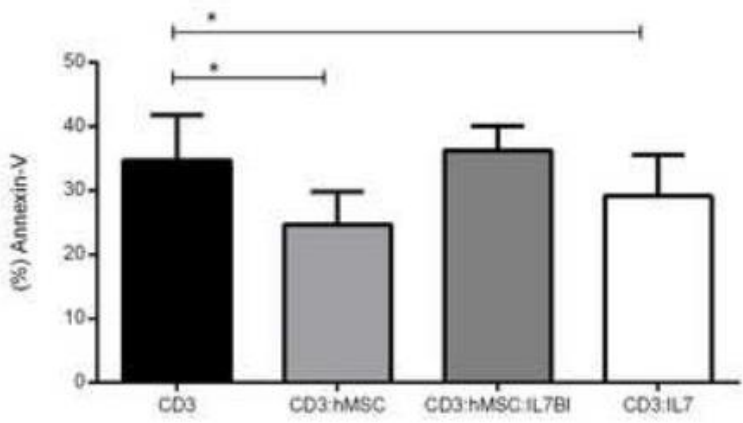

B

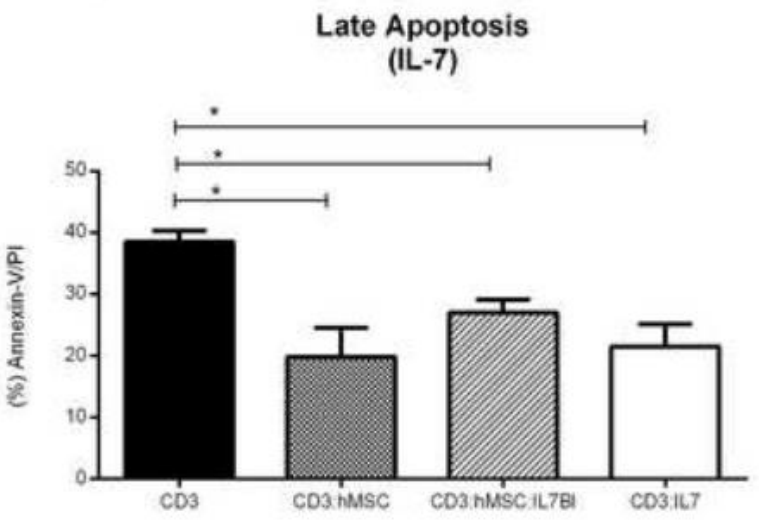

\section{FIGURE 11}
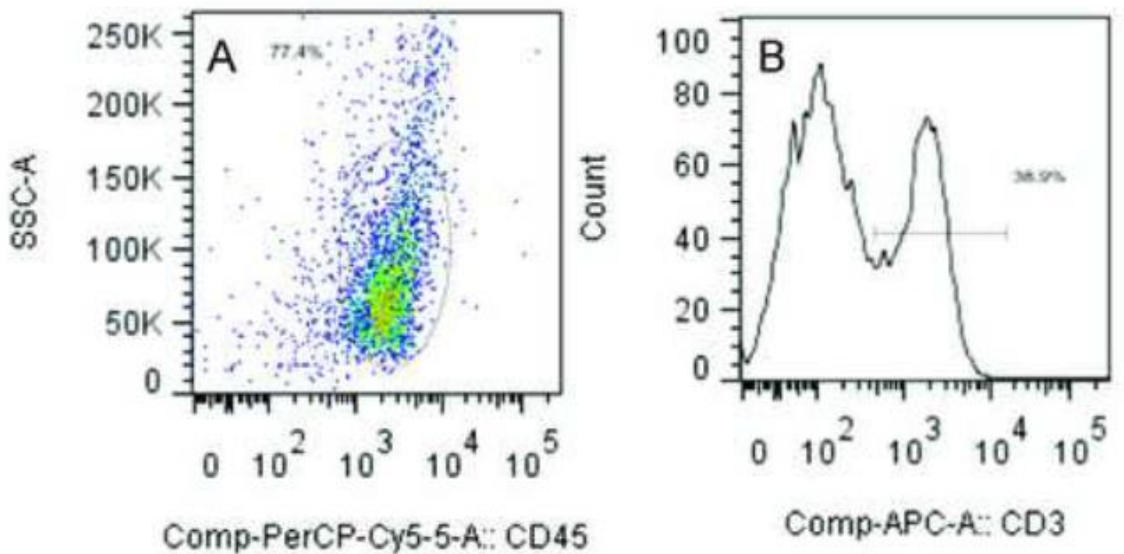

Comp-PerCP-Cy5-5-A:: CD45

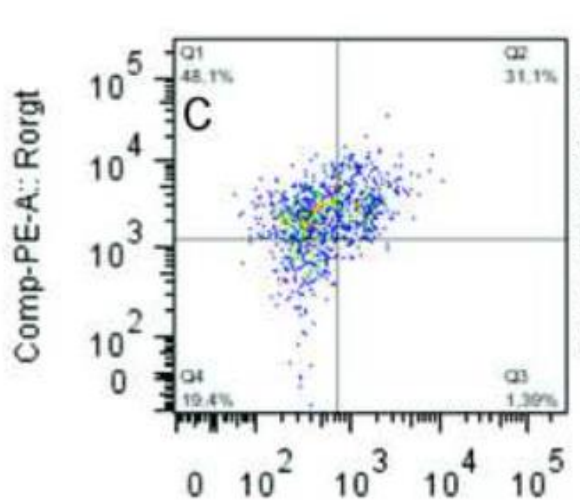

Comp-FITC-A: I-17A

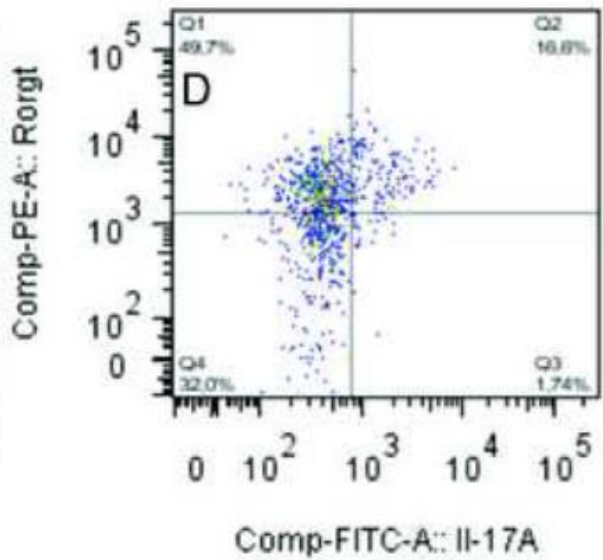


FIGURE 12
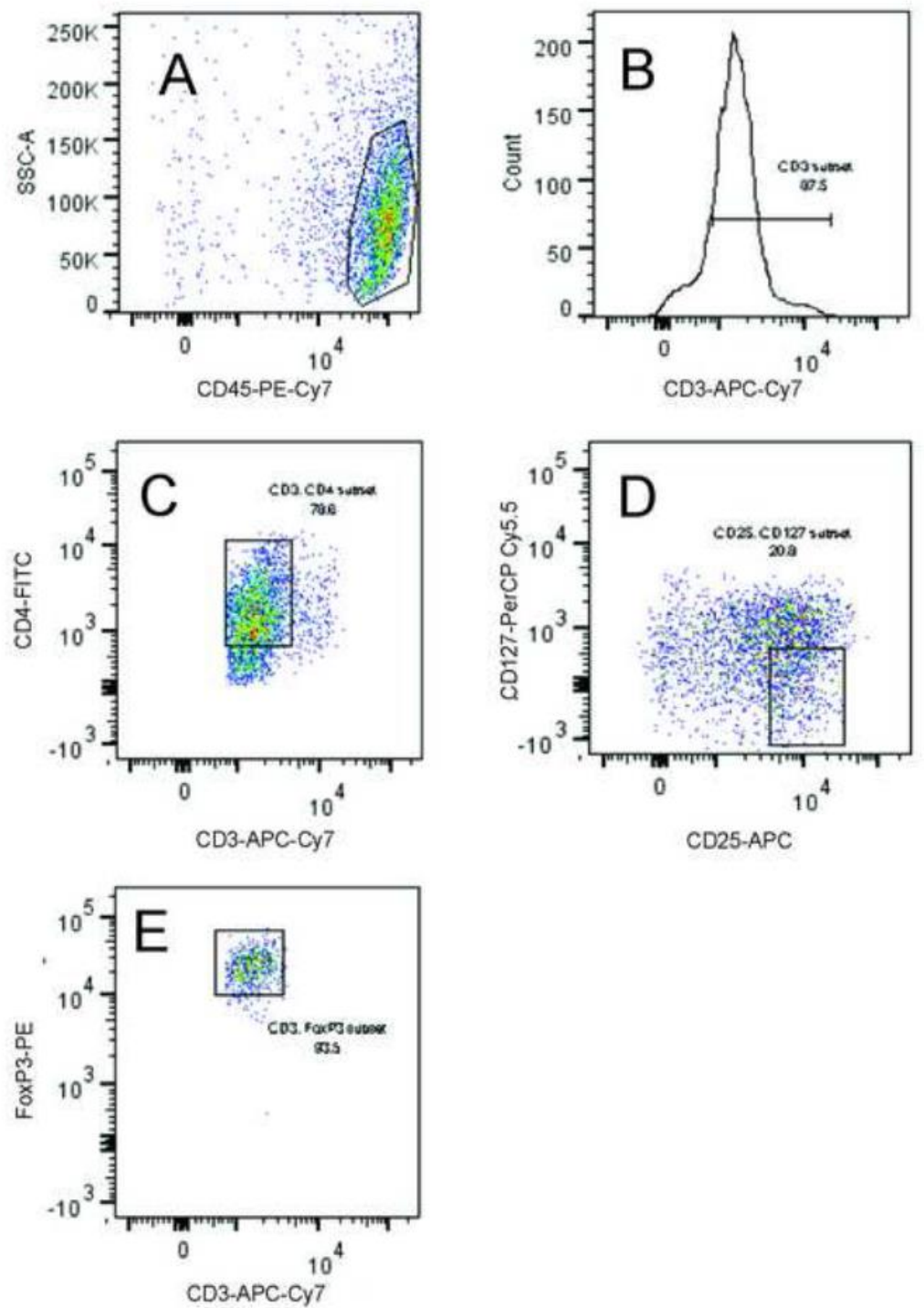

FIGURE 13

Regulatory $\mathrm{T}$ cell

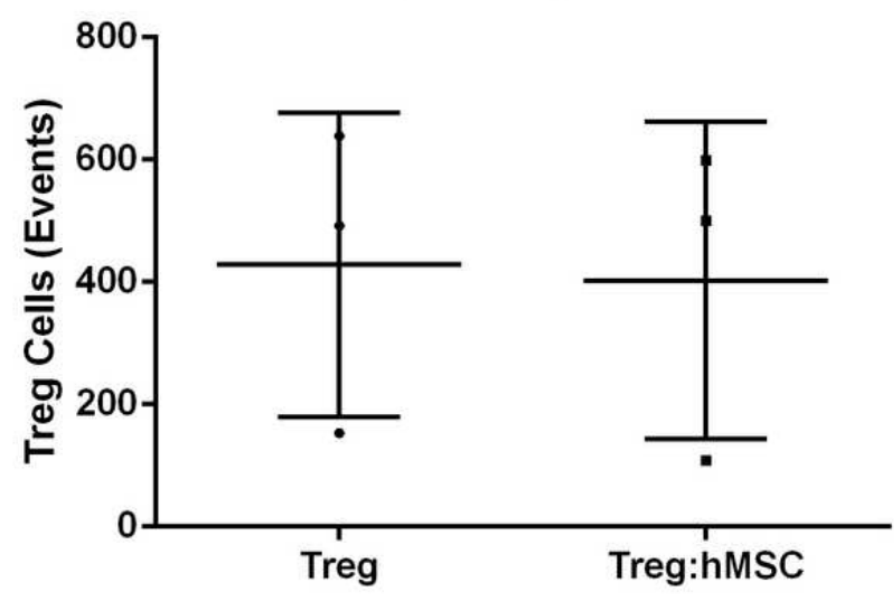


FIGURE 14

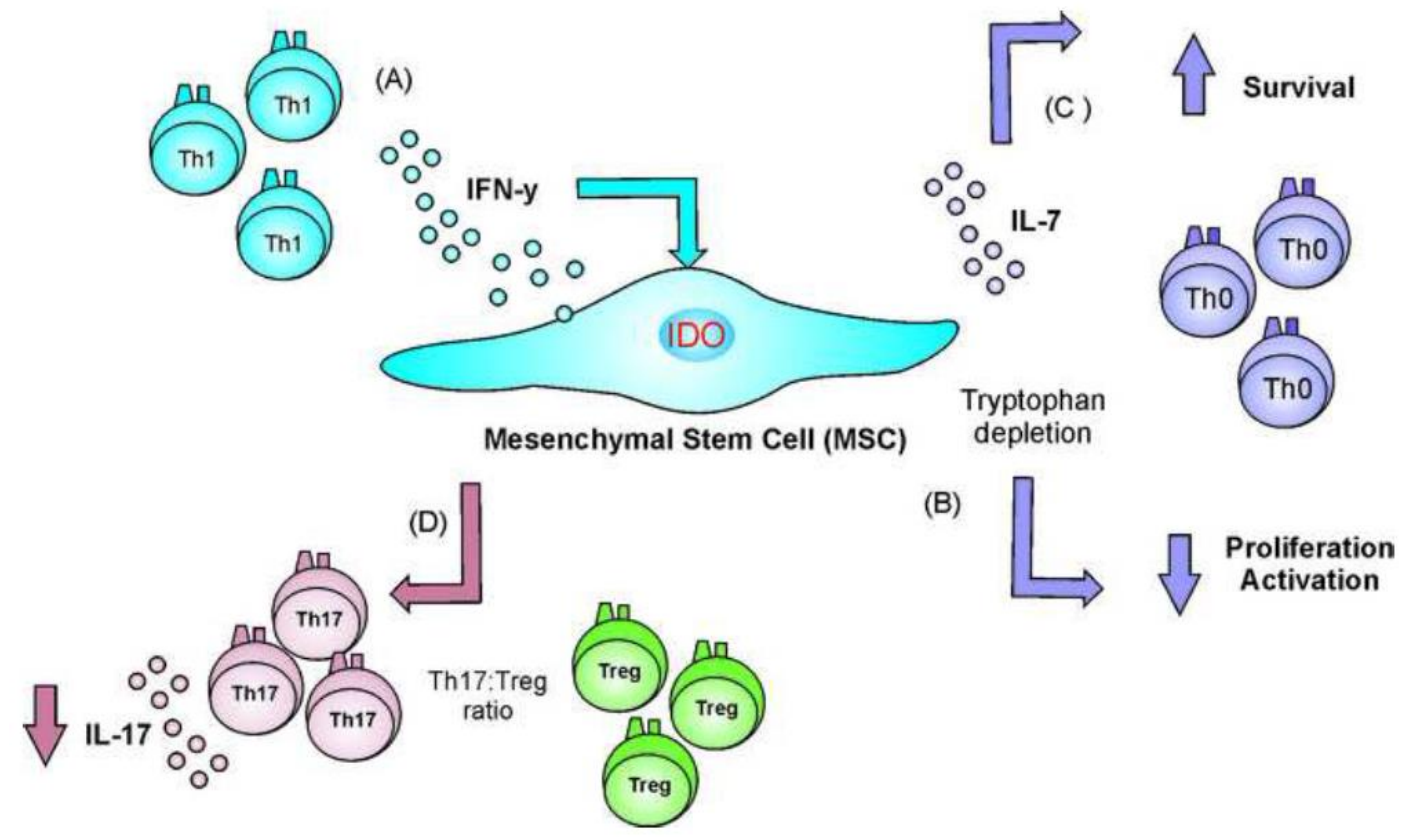




\section{REFERENCES}

1- .Le Blanc K, Rasmusson I, Sundberg B, et al. Treatment of severe acute graft-versus-host disease with third party haploidentical mesenchymal stem cells. Lancet 2004; 363(9419): 1439-41.

2- Friedenstein AJ, Deriglasova UF, Kulagina NN, et al. Precursors for fibroblasts in different populations of hematopoietic cells as detected by the in vitro colony assay method. Experimental hematology 1974; 2(2): 83-92.

3- Pittenger MF, Mackay AM, Beck SC, et al. Multilineage potential of adult human mesenchymal stem cells. Science $1999 ; 284(5411): 143-7$.

4- Dominici M, Le Blanc K, Mueller I, et al. Minimal criteria for defining multipotent mesenchymal stromal cells. The International Society for Cellular Therapy position statement. Cytotherapy. 2006;8(4):315-7.

5- Prockop DJ. Marrow stromal cells as stem cells for nonhematopoietic tissues. Science 1997; 276(5309): 71-4.

6- Beyer Nardi N, da Silva Meirelles L. Mesenchymal stem cells: isolation, in vitro expansion and characterization. Handbook of experimental pharmacology 2006; (174): 249-82.

7- Ding DC, Shyu WC, Lin SZ. Mesenchymal stem cells. Cell transplantation 2011; 20(1): 5-14.

8- Ren G, Su J, Zhang L, et al. Species variation in the mechanisms of mesenchymal stem cell-mediated immunosuppression. Stem cells 2009; 27(8): 1954-62.

9- Bernardo ME, Fibbe WE. Mesenchymal stromal cells: sensors and switchers of inflammation. Cell stem cell $2013 ; 13(4): 392-402$

10- Di Nicola M, Carlo-Stella C, Magni M, Milanesi M, et al. Human bone marrow stromal cells suppress Tlymphocyte proliferation induced by cellular or nonspecific mitogenic stimuli. Blood 2002; 99(10): 383843.

11- Meisel R, Zibert A, Laryea M, Gobel U, Daubener W, Dilloo D. Human bone marrow stromal cells inhibit allogeneic T-cell responses by indoleamine 2,3-dioxygenase-mediated tryptophan degradation. Blood 2004; 103(12): 4619-21.

12- Aggarwal S, Pittenger MF. Human mesenchymal stem cells modulate allogeneic immune cell responses. Blood 2005; 105(4): 1815-22.

13- Krampera M, Glennie S, Dyson J, et al. Bone marrow mesenchymal stem cells inhibit the response of naive and memory antigen-specific T cells to their cognate peptide. Blood 2003; 101(9): 3722-9. 
14- Sato K, Ozaki $\mathrm{K}, \mathrm{Oh} \mathrm{I}$, et al. Nitric oxide plays a critical role in suppression of T-cell proliferation by mesenchymal stem cells. Blood 2007; 109(1): 228-34

15- Mendez-Ferrer S, Michurina TV, Ferraro F, et al. Mesenchymal and haematopoietic stem cells form a unique bone marrow niche. Nature 2010; 466(7308): 829-34.

16- Rodriguez-Pardo VM, Vernot JP. Mesenchymal stem cells promote a primitive phenotype CD34+c-kit+ in human cord blood-derived hematopoietic stem cells during ex vivo expansion. Cellular \& molecular biology letters 2013; 18(1): 11-33.

17- Boomsma RA, Geenen DL. Mesenchymal stem cells secrete multiple cytokines that promote angiogenesis and have contrasting effects on chemotaxis and apoptosis. PloS one 2012; 7(4): e35685.

18- Tan JT, Dudl E, LeRoy E, et al. IL-7 is critical for homeostatic proliferation and survival of naive T cells. Proceedings of the National Academy of Sciences of the United States of America 2001; 98(15): 8732-7.

19- Khaled AR, Durum SK. Lymphocide: cytokines and the control of lymphoid homeostasis. Nature reviews. Immunology 2002; 2(11): 817-30.

20- Deus GC, Normanton M, Hamerschlak N, et al. Isolation and characterization of mesenchymal stem cells obtained from reusable and disposable bone marrow collection filters. Einstein 2012; 10(3): 296-301.

21- Normanton M, Marti LC. Current data on IL-17 and Th17 cells and implications for graft versus host disease. Einstein 2013; 11(2): 237-46.

22- Kim J, Hematti P. Mesenchymal stem cell-educated macrophages: a novel type of alternatively activated macrophages. Experimental hematology 2009; 37(12): 1445-53.

23- Rasmusson I, Ringden O, Sundberg B, Le Blanc K. Mesenchymal stem cells inhibit lymphocyte proliferation by mitogens and alloantigens by different mechanisms. Experimental cell research $2005 ; 305(1): 33-41$.

24- Nemeth K, Leelahavanichkul A, Yuen PS, et al. Bone marrow stromal cells attenuate sepsis via prostaglandin $\mathrm{E}(2)$-dependent reprogramming of host macrophages to increase their interleukin-10 production. Nature medicine $2009 ; 15(1): 42-9$.

25- Ryan JM, Barry F, Murphy JM, Mahon BP. Interferon-gamma does not break, but promotes the immunosuppressive capacity of adult human mesenchymal stem cells. Clinical and experimental immunology 2007; 149(2): 353-63. 
26- Francois M, Romieu-Mourez R, Li M, Galipeau J. Human MSC suppression correlates with cytokine induction of indoleamine 2,3-dioxygenase and bystander M2 macrophage differentiation. Molecular therapy : the joumal of the American Society of Gene Therapy 2012; 20(1): 187-95.

27- Benvenuto F, Ferrari S, Gerdoni E, et al. Human mesenchymal stem cells promote survival of $T$ cells in a quiescent state. Stem cells 2007; 25(7): 1753-60.

28- Ramasamy R, Lam EW, Soeiro I, Tisato V, Bonnet D, Dazzi F. Mesenchymal stem cells inhibit proliferation and apoptosis of tumor cells: impact on in vivo tumor growth. Leukemia 2007; 21(2): 304-10.

29- Khubutiya MS, Vagabov AV, Temnov AA, Sklifas AN. Paracrine mechanisms of proliferative, antiapoptotic and anti-inflammatory effects of mesenchymal stromal cells in models of acute organ injury. Cytotherapy 2013.

30- Danial NN, Korsmeyer SJ. Cell death: critical control points. Cell. 2004;116(2):205-19.

31- Hofmeister R, Khaled AR, Benbernou N, Rajnavolgyi E, Muegge K, Durum SK. Interleukin-7: physiological roles and mechanisms of action. Cytokine Growth Factor Rev. 1999;10(1):41-60.

32- A1-Rawi MA, Mansel RE, Jiang WG. Interleukin-7 (IL-7) and IL-7 receptor (IL-7R) signalling complex in human solid tumours. Histology and histopathology 2003; 18(3): 911-23.

33- De Miguel MP, Fuentes-Julián S, Blázquez-Martínez A, Pascual CY, Aller MA, Arias J, Arnalich-Montiel F. Immunosuppressive properties of mesenchymal stem cells: advances and applications. Curr Mol Med. 2012;12(5):574-91.

34- Ghannam S, Pene J, Moquet-Torcy G, Jorgensen C, Yssel H. Correction: mesenchymal stem cells inhibit human th17 cell differentiation and function and induce a $\mathrm{T}$ regulatory cell phenotype. Journal of imminology 2013; 191(11): 5777. 


\section{REFERÊNCIAS BIBLIOGRÁFICAS}

1. Vivier E, Malissen B. Innate and adaptive immunity: specificities and signaling hierarchies revisited. Nature immunology. 2005 Jan;6(1):17-21. PubMed PMID: 15611777.

2. Medzhitov R, Janeway C, Jr. Innate immunity. The New England journal of medicine. 2000 Aug 3;343(5):338-44. PubMed PMID: 10922424.

3. Medzhitov R, Preston-Hurlburt P, Janeway CA, Jr. A human homologue of the Drosophila Toll protein signals activation of adaptive immunity. Nature. 1997 Jul 24;388(6640):394-7. PubMed PMID: 9237759.

4. Theofilopoulos AN, Kono DH, Beutler B, Baccala R. Intracellular nucleic acid sensors and autoimmunity. Journal of interferon \& cytokine research : the official journal of the International Society for Interferon and Cytokine Research. 2011 Dec;31(12):867-86. PubMed PMID: 22029446. Pubmed Central PMCID: 3234494.

5. Baccala R, Gonzalez-Quintial R, Lawson BR, Stern ME, Kono DH, Beutler B, et al. Sensors of the innate immune system: their mode of action. Nature reviews Rheumatology. 2009 Aug;5(8):448-56. PubMed PMID: 19597511.

6. Newton K, Dixit VM. Signaling in innate immunity and inflammation. Cold Spring Harbor perspectives in biology. 2012 Mar;4(3). PubMed PMID: 22296764.

7. Iwasaki A, Medzhitov R. Regulation of adaptive immunity by the innate immune system. Science. 2010 Jan 15;327(5963):291-5. PubMed PMID: 20075244. Pubmed Central PMCID: 3645875 .

8. Steinman RM. Dendritic cells: understanding immunogenicity. European journal of immunology. 2007 Nov;37 Suppl 1:S53-60. PubMed PMID: 17972346.

9. Banchereau J, Briere F, Caux C, Davoust J, Lebecque S, Liu YJ, et al. Immunobiology of dendritic cells. Annual review of immunology. 2000;18:767-811. PubMed PMID: 10837075.

10. Brownlie RJ, Zamoyska R. T cell receptor signalling networks: branched, diversified and bounded. Nature reviews Immunology. 2013 Apr;13(4):257-69. PubMed PMID: 23524462.

11. Cruvinel Wde M, Mesquita D, Jr., Araujo JA, Catelan TT, de Souza AW, da Silva NP, et al. Immune system - part I. Fundamentals of innate immunity with emphasis on molecular and cellular mechanisms of inflammatory response. Revista brasileira de reumatologia. 2010 Jul-Aug;50(4):43461. PubMed PMID: 21125178.

12. Nitta T, Murata S, Ueno T, Tanaka K, Takahama Y. Thymic microenvironments for T-cell repertoire formation. Advances in immunology. 2008;99:59-94. PubMed PMID: 19117532.

13. Saint-Ruf C, Ungewiss K, Groettrup M, Bruno L, Fehling HJ, von Boehmer H. Analysis and expression of a cloned pre-T cell receptor gene. Science. 1994 Nov 18;266(5188):1208-12. PubMed PMID: 7973703.

14. Shinkai Y, Koyasu S, Nakayama K, Murphy KM, Loh DY, Reinherz EL, et al. Restoration of $\mathrm{T}$ cell development in RAG-2-deficient mice by functional TCR transgenes. Science. 1993 Feb 5;259(5096):822-5. PubMed PMID: 8430336.

15. Reinherz EL, Kung PC, Goldstein G, Schlossman SF. Separation of functional subsets of human $\mathrm{T}$ cells by a monoclonal antibody. Proceedings of the National Academy of Sciences of the United States of America. 1979 Aug;76(8):4061-5. PubMed PMID: 315070. Pubmed Central PMCID: 383977.

16. Ashton-Rickardt PG, Van Kaer L, Schumacher TN, Ploegh HL, Tonegawa S. Peptide contributes to the specificity of positive selection of CD8+ T cells in the thymus. Cell. 1993 Jun 4;73(5):1041-9. PubMed PMID: 8500174.

17. Takahama Y, Suzuki H, Katz KS, Grusby MJ, Singer A. Positive selection of CD4+ T cells by TCR ligation without aggregation even in the absence of MHC. Nature. 1994 Sep 1;371(6492):6770. PubMed PMID: 7915400.

18. Kyewski B, Derbinski J. Self-representation in the thymus: an extended view. Nature reviews Immunology. 2004 Sep;4(9):688-98. PubMed PMID: 15343368.

19. Kyewski B, Derbinski J, Gotter J, Klein L. Promiscuous gene expression and central T-cell tolerance: more than meets the eye. Trends in immunology. 2002 Jul;23(7):364-71. PubMed PMID: 12103357. 
20. Kyewski B, Klein L. A central role for central tolerance. Annual review of immunology. 2006;24:571-606. PubMed PMID: 16551260.

21. Klein L, Hinterberger M, Wirnsberger G, Kyewski B. Antigen presentation in the thymus for positive selection and central tolerance induction. Nature reviews Immunology. 2009 Dec;9(12):83344. PubMed PMID: 19935803.

22. Sinclair C, Bains I, Yates AJ, Seddon B. Asymmetric thymocyte death underlies the CD4:CD8 T-cell ratio in the adaptive immune system. Proceedings of the National Academy of Sciences of the United States of America. 2013 Jul 30;110(31):E2905-14. PubMed PMID: 23858460. Pubmed Central PMCID: 3732981.

23. Felix NJ, Allen PM. Specificity of T-cell alloreactivity. Nature reviews Immunology. 2007 Dec;7(12):942-53. PubMed PMID: 18007679.

24. Sherman LA, Chattopadhyay S. The molecular basis of allorecognition. Annual review of immunology. 1993;11:385-402. PubMed PMID: 8476567.

25. Steinman RM, Witmer MD. Lymphoid dendritic cells are potent stimulators of the primary mixed leukocyte reaction in mice. Proceedings of the National Academy of Sciences of the United States of America. 1978 Oct;75(10):5132-6. PubMed PMID: 154105. Pubmed Central PMCID: 336278.

26. Harrington LE, Hatton RD, Mangan PR, Turner H, Murphy TL, Murphy KM, et al. Interleukin 17-producing CD4+ effector T cells develop via a lineage distinct from the T helper type 1 and 2 lineages. Nature immunology. 2005 Nov;6(11):1123-32. PubMed PMID: 16200070.

27. Veldhoen M, Hocking RJ, Atkins CJ, Locksley RM, Stockinger B. TGFbeta in the context of an inflammatory cytokine milieu supports de novo differentiation of IL-17-producing $\mathrm{T}$ cells. Immunity. 2006 Feb;24(2):179-89. PubMed PMID: 16473830.

28. Kryczek I, Wei S, Vatan L, Escara-Wilke J, Szeliga W, Keller ET, et al. Cutting edge: opposite effects of IL-1 and IL-2 on the regulation of IL-17+ T cell pool IL-1 subverts IL-2-mediated suppression. Journal of immunology. 2007 Aug 1;179(3):1423-6. PubMed PMID: 17641006.

29. Baumgart DC, Carding SR. Inflammatory bowel disease: cause and immunobiology. Lancet. 2007 May 12;369(9573):1627-40. PubMed PMID: 17499605.

30. Mangan PR, Harrington LE, O'Quinn DB, Helms WS, Bullard DC, Elson CO, et al. Transforming growth factor-beta induces development of the $\mathrm{T}(\mathrm{H}) 17$ lineage. Nature. 2006 May 11;441(7090):231-4. PubMed PMID: 16648837.

31. Langowski JL, Zhang X, Wu L, Mattson JD, Chen T, Smith K, et al. IL-23 promotes tumour incidence and growth. Nature. 2006 Jul 27;442(7101):461-5. PubMed PMID: 16688182.

32. Hori S, Nomura T, Sakaguchi S. Control of regulatory $\mathrm{T}$ cell development by the transcription factor Foxp3. Science. 2003 Feb 14;299(5609):1057-61. PubMed PMID: 12522256.

33. Fontenot JD, Rudensky AY. A well adapted regulatory contrivance: regulatory $\mathrm{T}$ cell development and the forkhead family transcription factor Foxp3. Nature immunology. 2005 Apr;6(4):331-7. PubMed PMID: 15785758.

34. Igney FH, Krammer PH. Death and anti-death: tumour resistance to apoptosis. Nature reviews Cancer. 2002 Apr;2(4):277-88. PubMed PMID: 12001989.

35. Bouillet P, O'Reilly LA. CD95, BIM and T cell homeostasis. Nature reviews Immunology. 2009 Jul;9(7):514-9. PubMed PMID: 19543226.

36. Elmore S. Apoptosis: a review of programmed cell death. Toxicologic pathology. 2007 Jun;35(4):495-516. PubMed PMID: 17562483. Pubmed Central PMCID: 2117903.

37. Schluns KS, Kieper WC, Jameson SC, Lefrancois L. Interleukin-7 mediates the homeostasis of naive and memory CD8 T cells in vivo. Nature immunology. 2000 Nov;1(5):426-32. PubMed PMID: 11062503 .

38. Tan JT, Dudl E, LeRoy E, Murray R, Sprent J, Weinberg KI, et al. IL-7 is critical for homeostatic proliferation and survival of naive $\mathrm{T}$ cells. Proceedings of the National Academy of Sciences of the United States of America. 2001 Jul 17;98(15):8732-7. PubMed PMID: 11447288. Pubmed Central PMCID: 37504.

39. Khaled AR, Durum SK. Lymphocide: cytokines and the control of lymphoid homeostasis. Nature reviews Immunology. 2002 Nov;2(11):817-30. PubMed PMID: 12415306.

40. Kondrack RM, Harbertson J, Tan JT, McBreen ME, Surh CD, Bradley LM. Interleukin 7 regulates the survival and generation of memory CD4 cells. The Journal of experimental medicine. 2003 Dec 15;198(12):1797-806. PubMed PMID: 14662907. Pubmed Central PMCID: 2194153. 
41. Maraskovsky E, O'Reilly LA, Teepe M, Corcoran LM, Peschon JJ, Strasser A. Bcl-2 can rescue $\mathrm{T}$ lymphocyte development in interleukin-7 receptor-deficient mice but not in mutant rag-1-/mice. Cell. 1997 Jun 27;89(7):1011-9. PubMed PMID: 9215624.

42. Vander Heiden MG, Chandel NS, Schumacker PT, Thompson CB. Bcl-xL prevents cell death following growth factor withdrawal by facilitating mitochondrial ATP/ADP exchange. Molecular cell. 1999 Feb;3(2):159-67. PubMed PMID: 10078199.

43. Kim K, Khaled AR, Reynolds D, Young HA, Lee CK, Durum SK. Characterization of an interleukin-7-dependent thymic cell line derived from a p53(-/-) mouse. Journal of immunological methods. 2003 Mar 1;274(1-2):177-84. PubMed PMID: 12609543.

44. Thomas ED. A history of haemopoietic cell transplantation. British journal of haematology. 1999 May;105(2):330-9. PubMed PMID: 10233401. Epub 1999/05/08. eng.

45. van Bekkum DW, de Vries MJ, van der Waay D. Lesions characteristic of secondary disease in germfree heterologous radiation chimeras. Journal of the National Cancer Institute. 1967 Feb;38(2):223-31. PubMed PMID: 6019733. Epub 1967/02/01. eng.

46. Billingham RE, Brent L. Quantitative Studies on Tissue Transplantation Immunity .4. Induction of Tolerance in Newborn Mice and Studies on the Phenomenon of Runt Disease. Philos T Roy Soc B. 1959;242(694):439-77. PubMed PMID: ISI:A1959WX75800001. English.

47. Uphoff DE. Genetic factors influencing irradiation protection by bone marrow. I. The F1 hybrid effect. Journal of the National Cancer Institute. 1957 Jul;19(1):123-30. PubMed PMID: 13502711. Epub 1957/07/01. eng.

48. Snell GD. The Nobel Lectures in Immunology. Lecture for the Nobel Prize for Physiology or Medicine, 1980: Studies in histocompatibility. Scandinavian journal of immunology. 1992 Oct;36(4):513-26. PubMed PMID: 1411297. Epub 1992/10/01. eng.

49. Uphoff DE. Alteration of homograft reaction by A-methopterin in lethally irradiated mice treated with homologous marrow. Proc Soc Exp Biol Med. 1958 Dec;99(3):651-3. PubMed PMID: 13614453. Epub 1958/12/01. eng.

50. Lochte HL, Jr., Levy AS, Guenther DM, Thomas ED, Ferrebee JW. Prevention of delayed foreign marrow reaction in lethally irradiated mice by early administration of methotrexate. Nature. 1962 Dec 15;196:1110-1. PubMed PMID: 13931175. Epub 1962/12/15. eng.

51. Santos GW, Owens AH, Jr. Allogeneic marrow transplants in cyclophosphamide treated mice. Transplantation proceedings. 1969 Mar;1(1):44-6. PubMed PMID: 4400067. Epub 1969/03/01. eng.

52. Good RA, Dalmasso AP, Martinez C, Archer OK, Pierce JC, Papermaster BW. The role of the thymus in development of immunologic capacity in rabbits and mice. The Journal of experimental medicine. 1962 Nov 1;116:773-96. PubMed PMID: 13949053. Pubmed Central PMCID: 2137569. Epub 1962/11/01. eng.

53. Miller JF. Role of the Thymus in Immunity. British medical journal. 1963 Aug 24;2(5355):459-64. PubMed PMID: 14043707. Pubmed Central PMCID: 1874012. Epub 1963/08/24. eng.

54. Gatti RA, Meuwissen HJ, Allen HD, Hong R, Good RA. Immunological reconstitution of sex-linked lymphopenic immunological deficiency. Lancet. 1968 Dec 28;2(7583):1366-9. PubMed PMID: 4177932. Epub 1968/12/28. eng.

55. Bach FH, Albertini RJ, Joo P, Anderson JL, Bortin MM. Bone-marrow transplantation in a patient with the Wiskott-Aldrich syndrome. Lancet. 1968 Dec 28;2(7583):1364-6. PubMed PMID: 4177931. Epub 1968/12/28. eng.

56. De Koning J, Van Bekkum DW, Dicke KA, Dooren LJ, Radl J, Van Rood JJ. Transplantation of bone-marrow cells and fetal thymus in an infant with lymphopenic immunological deficiency. Lancet. 1969 Jun 21;1(7608):1223-7. PubMed PMID: 4182410. Epub 1969/06/21. eng.

57. Bortin MM, Bach FH, van Bekkum DW, Good RA, van Rood JJ. 25th anniversary of the first successful allogeneic bone marrow transplants. Bone marrow transplantation. 1994 Aug;14(2):211-2. PubMed PMID: 7994234.

58. Horowitz MM. Uses and Growth of Hematopoietic Cell Transplantation. Thomas' Hematopoietic Cell Transplantation: Wiley-Blackwell; 2009. p. 15-21.

59. Pirofsky B. Profile of Edwin E. Osgood, M. D. Blood. 1969 Feb;33(2):265-7. PubMed PMID: 4886118.

60. Park BH, Good RA. Third party mixed-leukocyte culture test: a potential new method of histocompatibility testing. Proceedings of the National Academy of Sciences of the United States of America. 1972 Jun;69(6):1490-3. PubMed PMID: 4113869. Pubmed Central PMCID: 426733. 
61. Jansen J. The first successful allogeneic bone-marrow transplant: Georges Mathe. Transfusion medicine reviews. 2005 Jul;19(3):246-8. PubMed PMID: 16010655.

62. Ferreira E, Dulley FL, Morsoletto F, Neto JZ, Pasquini R. Bone marrow transplantation in Brazil. Human immunology. 1985 Nov;14(3):324-32. PubMed PMID: 3902750.

63. Ferrara JL, Levine JE, Reddy P, Holler E. Graft-versus-host disease. Lancet. 2009 May 2;373(9674):1550-61. PubMed PMID: 19282026. Pubmed Central PMCID: 2735047. Epub 2009/03/14. eng.

64. Pasquini MC, Wang Z, Horowitz MM, Gale RP. 2010 report from the Center for International Blood and Marrow Transplant Research (CIBMTR): current uses and outcomes of hematopoietic cell transplants for blood and bone marrow disorders. Clinical transplants. 2010:87105. PubMed PMID: 21696033. Epub 2010/01/01. eng.

65. Shulman HM, Sullivan KM, Weiden PL, McDonald GB, Striker GE, Sale GE, et al. Chronic graft-versus-host syndrome in man. A long-term clinicopathologic study of 20 Seattle patients. The American journal of medicine. 1980 Aug;69(2):204-17. PubMed PMID: 6996481. Epub 1980/08/01. eng.

66. Filipovich AH, Weisdorf D, Pavletic S, Socie G, Wingard JR, Lee SJ, et al. National Institutes of Health consensus development project on criteria for clinical trials in chronic graftversus-host disease: I. Diagnosis and staging working group report. Biology of blood and marrow transplantation : journal of the American Society for Blood and Marrow Transplantation. 2005 Dec;11(12):945-56. PubMed PMID: 16338616. Epub 2005/12/13. eng.

67. Shulman HM, Kleiner D, Lee SJ, Morton T, Pavletic SZ, Farmer E, et al. Histopathologic diagnosis of chronic graft-versus-host disease: National Institutes of Health Consensus Development Project on Criteria for Clinical Trials in Chronic Graft-versus-Host Disease: II. Pathology Working Group Report. Biology of blood and marrow transplantation : journal of the American Society for Blood and Marrow Transplantation. 2006 Jan;12(1):31-47. PubMed PMID: 16399567. Epub 2006/01/10. eng.

68. Schultz KR, Miklos DB, Fowler D, Cooke K, Shizuru J, Zorn E, et al. Toward biomarkers for chronic graft-versus-host disease: National Institutes of Health consensus development project on criteria for clinical trials in chronic graft-versus-host disease: III. Biomarker Working Group Report. Biology of blood and marrow transplantation : journal of the American Society for Blood and Marrow Transplantation. 2006 Feb;12(2):126-37. PubMed PMID: 16443511. Epub 2006/01/31. eng.

69. Pavletic SZ, Martin P, Lee SJ, Mitchell S, Jacobsohn D, Cowen EW, et al. Measuring therapeutic response in chronic graft-versus-host disease: National Institutes of Health Consensus Development Project on Criteria for Clinical Trials in Chronic Graft-versus-Host Disease: IV. Response Criteria Working Group report. Biology of blood and marrow transplantation : journal of the American Society for Blood and Marrow Transplantation. 2006 Mar;12(3):252-66. PubMed PMID: 16503494. Epub 2006/03/01. eng.

70. Couriel D, Carpenter PA, Cutler C, Bolanos-Meade J, Treister NS, Gea-Banacloche J, et al. Ancillary therapy and supportive care of chronic graft-versus-host disease: national institutes of health consensus development project on criteria for clinical trials in chronic Graft-versus-host disease: V. Ancillary Therapy and Supportive Care Working Group Report. Biology of blood and marrow transplantation : journal of the American Society for Blood and Marrow Transplantation. 2006 Apr;12(4):375-96. PubMed PMID: 16545722. Epub 2006/03/21. eng.

71. Martin PJ, Weisdorf D, Przepiorka D, Hirschfeld S, Farrell A, Rizzo JD, et al. National Institutes of Health Consensus Development Project on Criteria for Clinical Trials in Chronic Graftversus-Host Disease: VI. Design of Clinical Trials Working Group report. Biology of blood and marrow transplantation : journal of the American Society for Blood and Marrow Transplantation. 2006 May;12(5):491-505. PubMed PMID: 16635784. Epub 2006/04/26. eng.

72. Martin PJ, Inamoto Y, Carpenter PA, Lee SJ, Flowers ME. Treatment of chronic graftversus-host disease: Past, present and future. The Korean journal of hematology. 2011 Sep;46(3):15363. PubMed PMID: 22065969. Pubmed Central PMCID: 3208197. Epub 2011/11/09. eng.

73. Blazar BR, Murphy WJ, Abedi M. Advances in graft-versus-host disease biology and therapy. Nature reviews Immunology. 2012 Jun;12(6):443-58. PubMed PMID: 22576252. Epub 2012/05/12. eng.

74. Blaese RM, Martinez C, Good RA. Immunologic Incompetence of Immunologically Runted Animals. The Journal of experimental medicine. 1964 Feb 1;119:211-24. PubMed PMID: 14164479. Pubmed Central PMCID: 2137835. Epub 1964/02/01. eng. 
75. Choi SW, Levine JE, Ferrara JL. Pathogenesis and management of graft-versus-host disease. Immunology and allergy clinics of North America. 2010 Feb;30(1):75-101. PubMed PMID: 20113888. Epub 2010/02/02. eng.

76. Shimabukuro-Vornhagen A, Hallek MJ, Storb RF, von Bergwelt-Baildon MS. The role of B cells in the pathogenesis of graft-versus-host disease. Blood. 2009 Dec 3;114(24):4919-27. PubMed PMID: 19749094. Epub 2009/09/15. eng.

77. Socie G, Blazar BR. Acute graft-versus-host disease: from the bench to the bedside. Blood. 2009 Nov 12;114(20):4327-36. PubMed PMID: 19713461. Pubmed Central PMCID: 2777122. Epub 2009/08/29. eng.

78. Kraus PD, Wolff D, Grauer O, Angstwurm K, Jarius S, Wandinger KP, et al. Muscle Cramps and Neuropathies in Patients with Allogeneic Hematopoietic Stem Cell Transplantation and Graftversus-Host Disease. PloS one. 2012;7(9):e44922. PubMed PMID: 23028681. Pubmed Central PMCID: 3444502. Epub 2012/10/03. eng.

79. Korngold R, Sprent J. T cell subsets and graft-versus-host disease. Transplantation. 1987 Sep;44(3):335-9. PubMed PMID: 2957834. Epub 1987/09/01. eng.

80. Sprent J, Schaefer M, Lo D, Korngold R. Properties of purified T cell subsets. II. In vivo responses to class I vs. class II H-2 differences. The Journal of experimental medicine. 1986 Apr 1;163(4):998-1011. PubMed PMID: 3512763. Pubmed Central PMCID: 2188064. Epub 1986/04/01. eng.

81. Zheng H, Matte-Martone C, Li H, Anderson BE, Venketesan S, Sheng Tan H, et al. Effector memory CD4+ $\mathrm{T}$ cells mediate graft-versus-leukemia without inducing graft-versus-host disease. Blood. 2008 Feb 15;111(4):2476-84. PubMed PMID: 18045967. Pubmed Central PMCID: 2234071. Epub 2007/11/30. eng.

82. Teshima T. Th1 and Th17 join forces for acute GVHD. Blood. 2011 Nov 3;118(18):4765-7. PubMed PMID: 22053173. Epub 2011/11/05. eng.

83. Deng ZL, Sharff KA, Tang N, Song WX, Luo J, Luo X, et al. Regulation of osteogenic differentiation during skeletal development. Frontiers in bioscience : a journal and virtual library. 2008;13:2001-21. PubMed PMID: 17981687. Epub 2007/11/06. eng.

84. Friedenstein AJ, Petrakova KV, Kurolesova AI, Frolova GP. Heterotopic of bone marrow. Analysis of precursor cells for osteogenic and hematopoietic tissues. Transplantation. 1968 Mar;6(2):230-47. PubMed PMID: 5654088. Epub 1968/03/01. eng.

85. Luu HH, Song WX, Luo X, Manning D, Luo J, Deng ZL, et al. Distinct roles of bone morphogenetic proteins in osteogenic differentiation of mesenchymal stem cells. Journal of orthopaedic research : official publication of the Orthopaedic Research Society. 2007 May;25(5):66577. PubMed PMID: 17290432. Epub 2007/02/10. eng.

86. Horwitz EM, Le Blanc K, Dominici M, Mueller I, Slaper-Cortenbach I, Marini FC, et al. Clarification of the nomenclature for MSC: The International Society for Cellular Therapy position statement. Cytotherapy. 2005;7(5):393-5. PubMed PMID: 16236628. Epub 2005/10/21. eng.

87. Caplan AI. Mesenchymal stem cells. Journal of orthopaedic research : official publication of the Orthopaedic Research Society. 1991 Sep;9(5):641-50. PubMed PMID: 1870029. Epub 1991/09/01. eng.

88. Shi Y, Hu G, Su J, Li W, Chen Q, Shou P, et al. Mesenchymal stem cells: a new strategy for immunosuppression and tissue repair. Cell research. 2010 May;20(5):510-8. PubMed PMID: 20368733. Epub 2010/04/07. eng.

89. Ghannam S, Pene J, Torcy-Moquet G, Jorgensen C, Yssel H. Mesenchymal stem cells inhibit human Th17 cell differentiation and function and induce a T regulatory cell phenotype. J Immunol. 2010 Jul 1;185(1):302-12. PubMed PMID: 20511548. Epub 2010/06/01. eng.

90. Friedenstein AJ, Deriglasova UF, Kulagina NN, Panasuk AF, Rudakowa SF, Luria EA, et al. Precursors for fibroblasts in different populations of hematopoietic cells as detected by the in vitro colony assay method. Experimental hematology. 1974;2(2):83-92. PubMed PMID: 4455512.

91. Hwang NS, Zhang C, Hwang YS, Varghese S. Mesenchymal stem cell differentiation and roles in regenerative medicine. Wiley interdisciplinary reviews Systems biology and medicine. 2009 Jul-Aug;1(1):97-106. PubMed PMID: 20835984. Epub 2009/07/01. eng.

92. Pittenger MF, Mackay AM, Beck SC, Jaiswal RK, Douglas R, Mosca JD, et al. Multilineage potential of adult human mesenchymal stem cells. Science. 1999 Apr 2;284(5411):143-7. PubMed PMID: 10102814

93. Kopen GC, Prockop DJ, Phinney DG. Marrow stromal cells migrate throughout forebrain and cerebellum, and they differentiate into astrocytes after injection into neonatal mouse brains. 
Proceedings of the National Academy of Sciences of the United States of America. 1999 Sep 14;96(19):10711-6. PubMed PMID: 10485891. Pubmed Central PMCID: 17948. Epub 1999/09/15. eng.

94. Phinney DG, Prockop DJ. Concise review: mesenchymal stem/multipotent stromal cells: the state of transdifferentiation and modes of tissue repair--current views. Stem Cells. 2007 Nov;25(11):2896-902. PubMed PMID: 17901396. Epub 2007/09/29. eng.

95. Le Blanc K, Rasmusson I, Sundberg B, Gotherstrom C, Hassan M, Uzunel M, et al. Treatment of severe acute graft-versus-host disease with third party haploidentical mesenchymal stem cells. Lancet. 2004 May 1;363(9419):1439-41. PubMed PMID: 15121408.

96. Le Blanc K, Frassoni F, Ball L, Locatelli F, Roelofs H, Lewis I, et al. Mesenchymal stem cells for treatment of steroid-resistant, severe, acute graft-versus-host disease: a phase II study. Lancet. 2008 May 10;371(9624):1579-86. PubMed PMID: 18468541. Epub 2008/05/13. eng.

97. Djouad F, Bouffi C, Ghannam S, Noel D, Jorgensen C. Mesenchymal stem cells: innovative therapeutic tools for rheumatic diseases. Nature reviews Rheumatology. 2009 Jul;5(7):392-9. PubMed PMID: 19568253.

98. Ren G, Su J, Zhang L, Zhao X, Ling W, L'Huillie A, et al. Species variation in the mechanisms of mesenchymal stem cell-mediated immunosuppression. Stem cells. 2009 Aug;27(8):1954-62. PubMed PMID: 19544427.

99. Meisel R, Zibert A, Laryea M, Gobel U, Daubener W, Dilloo D. Human bone marrow stromal cells inhibit allogeneic T-cell responses by indoleamine 2,3-dioxygenase-mediated tryptophan degradation. Blood. 2004 Jun 15;103(12):4619-21. PubMed PMID: 15001472.

100. Aggarwal S, Pittenger MF. Human mesenchymal stem cells modulate allogeneic immune cell responses. Blood. 2005 Feb 15;105(4):1815-22. PubMed PMID: 15494428. Epub 2004/10/21. eng.

101. Di Nicola M, Carlo-Stella C, Magni M, Milanesi M, Longoni PD, Matteucci P, et al. Human bone marrow stromal cells suppress T-lymphocyte proliferation induced by cellular or nonspecific mitogenic stimuli. Blood. 2002 May 15;99(10):3838-43. PubMed PMID: 11986244.

102. Krampera M, Glennie S, Dyson J, Scott D, Laylor R, Simpson E, et al. Bone marrow mesenchymal stem cells inhibit the response of naive and memory antigen-specific $\mathrm{T}$ cells to their cognate peptide. Blood. 2003 May 1;101(9):3722-9. PubMed PMID: 12506037.

103. Djouad F, Charbonnier LM, Bouffi C, Louis-Plence P, Bony C, Apparailly F, et al. Mesenchymal stem cells inhibit the differentiation of dendritic cells through an interleukin-6dependent mechanism. Stem Cells. 2007 Aug;25(8):2025-32. PubMed PMID: 17510220. Epub 2007/05/19. eng.

104. Rasmusson I, Ringden O, Sundberg B, Le Blanc K. Mesenchymal stem cells inhibit the formation of cytotoxic $\mathrm{T}$ lymphocytes, but not activated cytotoxic $\mathrm{T}$ lymphocytes or natural killer cells. Transplantation. 2003 Oct 27;76(8):1208-13. PubMed PMID: 14578755. Epub 2003/10/28. eng. 105. Tabera S, Perez-Simon JA, Diez-Campelo M, Sanchez-Abarca LI, Blanco B, Lopez A, et al. The effect of mesenchymal stem cells on the viability, proliferation and differentiation of Blymphocytes. Haematologica. 2008 Sep;93(9):1301-9. PubMed PMID: 18641017. Epub 2008/07/22. eng.

106. Asari S, Itakura S, Ferreri K, Liu CP, Kuroda Y, Kandeel F, et al. Mesenchymal stem cells suppress B-cell terminal differentiation. Experimental hematology. 2009 May;37(5):604-15. PubMed PMID: 19375651. Pubmed Central PMCID: 2747661. Epub 2009/04/21. eng.

107. Shi M, Liu ZW, Wang FS. Immunomodulatory properties and therapeutic application of mesenchymal stem cells. Clinical and experimental immunology. 2011 Apr;164(1):1-8. PubMed PMID: 21352202. Pubmed Central PMCID: 3074211. Epub 2011/03/01. eng.

108. Sotiropoulou PA, Perez SA, Gritzapis AD, Baxevanis CN, Papamichail M. Interactions between human mesenchymal stem cells and natural killer cells. Stem Cells. 2006 Jan;24(1):74-85. PubMed PMID: 16099998. Epub 2005/08/16. eng.

109. Krampera M, Cosmi L, Angeli R, Pasini A, Liotta F, Andreini A, et al. Role for interferongamma in the immunomodulatory activity of human bone marrow mesenchymal stem cells. Stem cells. 2006 Feb;24(2):386-98. PubMed PMID: 16123384.

110. Ren G, Zhang L, Zhao X, Xu G, Zhang Y, Roberts AI, et al. Mesenchymal stem cellmediated immunosuppression occurs via concerted action of chemokines and nitric oxide. Cell stem cell. 2008 Feb 7;2(2):141-50. PubMed PMID: 18371435. Epub 2008/03/29. eng.

111. Maby-El Hajjami H, Ame-Thomas P, Pangault C, Tribut O, DeVos J, Jean R, et al. Functional alteration of the lymphoma stromal cell niche by the cytokine context: role of indoleamine- 
2,3 dioxygenase. Cancer research. 2009 Apr 1;69(7):3228-37. PubMed PMID: 19276371. Epub 2009/03/12. eng.

112. Nemeth K, Leelahavanichkul A, Yuen PS, Mayer B, Parmelee A, Doi K, et al. Bone marrow stromal cells attenuate sepsis via prostaglandin $\mathrm{E}(2)$-dependent reprogramming of host macrophages to increase their interleukin-10 production. Nature medicine. 2009 Jan;15(1):42-9. PubMed PMID: 19098906. Pubmed Central PMCID: 2706487.

113. Spaggiari GM, Abdelrazik H, Becchetti F, Moretta L. MSCs inhibit monocyte-derived DC maturation and function by selectively interfering with the generation of immature DCs: central role of MSC-derived prostaglandin E2. Blood. 2009 Jun 25;113(26):6576-83. PubMed PMID: 19398717. Epub 2009/04/29. eng.

114. Jiang XX, Zhang Y, Liu B, Zhang SX, Wu Y, Yu XD, et al. Human mesenchymal stem cells inhibit differentiation and function of monocyte-derived dendritic cells. Blood. 2005 May 15;105(10):4120-6. PubMed PMID: 15692068. Epub 2005/02/05. eng.

115. Fong EL, Chan CK, Goodman SB. Stem cell homing in musculoskeletal injury. Biomaterials. 2011 Jan;32(2):395-409. PubMed PMID: 20933277. Pubmed Central PMCID: 2991369. Epub 2010/10/12. eng.

116. Boomsma RA, Geenen DL. Mesenchymal stem cells secrete multiple cytokines that promote angiogenesis and have contrasting effects on chemotaxis and apoptosis. PloS one. 2012;7(4):e35685. PubMed PMID: 22558198. Pubmed Central PMCID: 3338452.

117. Hall B, Dembinski J, Sasser AK, Studeny M, Andreeff M, Marini F. Mesenchymal stem cells in cancer: tumor-associated fibroblasts and cell-based delivery vehicles. International journal of hematology. 2007 Jul;86(1):8-16. PubMed PMID: 17675260. Epub 2007/08/07. eng.

118. Aicher A, Brenner W, Zuhayra M, Badorff C, Massoudi S, Assmus B, et al. Assessment of the tissue distribution of transplanted human endothelial progenitor cells by radioactive labeling. Circulation. 2003 Apr 29;107(16):2134-9. PubMed PMID: 12695305. Epub 2003/04/16. eng.

119. Uccelli A, Moretta L, Pistoia V. Mesenchymal stem cells in health and disease. Nature reviews Immunology. 2008 Sep;8(9):726-36. PubMed PMID: 19172693. Epub 2009/01/28. eng.

120. Mestas J, Hughes CC. Of mice and not men: differences between mouse and human immunology. J Immunol. 2004 Mar 1;172(5):2731-8. PubMed PMID: 14978070. Epub 2004/02/24. eng.

121. Deus GC, Normanton M, Hamerschlak N, Kondo AT, Ribeiro AA, Goldberg AC, et al. Isolation and characterization of mesenchymal stem cells obtained from reusable and disposable bone marrow collection filters. Einstein. 2012 Jul-Sep;10(3):296-301. PubMed PMID: 23386007.

122. Gerdes J, Schwab U, Lemke H, Stein H. Production of a mouse monoclonal antibody reactive with a human nuclear antigen associated with cell proliferation. International journal of cancer Journal international du cancer. 1983 Jan 15;31(1):13-20. PubMed PMID: 6339421.

123. Fallarino F, Grohmann U, Puccetti P. Indoleamine 2,3-dioxygenase: from catalyst to signaling function. European journal of immunology. 2012 Aug;42(8):1932-7. PubMed PMID: 22865044 .

124. Dai H, Dai Z. The role of tryptophan catabolism in acquisition and effector function of memory $\mathrm{T}$ cells. Current opinion in organ transplantation. 2008 Feb;13(1):31-5. PubMed PMID: 18660704.

125. Chen W, Liang X, Peterson AJ, Munn DH, Blazar BR. The indoleamine 2,3-dioxygenase pathway is essential for human plasmacytoid dendritic cell-induced adaptive $\mathrm{T}$ regulatory cell generation. Journal of immunology. 2008 Oct 15;181(8):5396-404. PubMed PMID: 18832696. Pubmed Central PMCID: 2614675.

126. Liu YB, Qian HR, Hong DF, Wang JW, Li JT, Wang XA, et al. [Mesenchymal stem cells inhibit the expression of CD25 on phytohaemagglutinin-activated lymphocytes]. Zhonghua yi xue za zhi. 2007 Aug 14;87(30):2136-9. PubMed PMID: 17988536.

127. Le Blanc K, Rasmusson I, Gotherstrom C, Seidel C, Sundberg B, Sundin M, et al. Mesenchymal stem cells inhibit the expression of CD25 (interleukin-2 receptor) and CD38 on phytohaemagglutinin-activated lymphocytes. Scandinavian journal of immunology. 2004 Sep;60(3):307-15. PubMed PMID: 15320889.

128. Wei YJ, Lin YJ. [Recent research advance in immunomodulatory function of mesenchymal stem cells on immune cells]. Zhongguo shi yan xue ye xue za zhi / Zhongguo bing li sheng li xue hui $=$ Journal of experimental hematology / Chinese Association of Pathophysiology. 2010 Aug;18(4):1079-83. PubMed PMID: 20723333. 
129. Kim J, Hematti P. Mesenchymal stem cell-educated macrophages: a novel type of alternatively activated macrophages. Experimental hematology. 2009 Dec;37(12):1445-53. PubMed PMID: 19772890. Pubmed Central PMCID: 2783735.

130. Normanton M, Marti LC. Current data on IL-17 and Th17 cells and implications for graft versus host disease. Einstein. 2013 Apr-Jun;11(2):237-46. PubMed PMID: 23843069.

131. Ghannam S, Pene J, Moquet-Torcy G, Jorgensen C, Yssel H. Correction: mesenchymal stem cells inhibit human th17 cell differentiation and function and induce a T regulatory cell phenotype. Journal of immunology. 2013 Dec 1;191(11):5777. PubMed PMID: 24244029.

132. Rasmusson I, Ringden O, Sundberg B, Le Blanc K. Mesenchymal stem cells inhibit lymphocyte proliferation by mitogens and alloantigens by different mechanisms. Experimental cell research. 2005 Apr 15;305(1):33-41. PubMed PMID: 15777785.

133. Ryan JM, Barry F, Murphy JM, Mahon BP. Interferon-gamma does not break, but promotes the immunosuppressive capacity of adult human mesenchymal stem cells. Clinical and experimental immunology. 2007 Aug;149(2):353-63. PubMed PMID: 17521318. Pubmed Central PMCID: 1941956.

134. Francois M, Romieu-Mourez R, Li M, Galipeau J. Human MSC suppression correlates with cytokine induction of indoleamine 2,3-dioxygenase and bystander M2 macrophage differentiation. Molecular therapy : the journal of the American Society of Gene Therapy. 2012 Jan;20(1):187-95. PubMed PMID: 21934657.

135. Benvenuto F, Ferrari S, Gerdoni E, Gualandi F, Frassoni F, Pistoia V, et al. Human mesenchymal stem cells promote survival of $\mathrm{T}$ cells in a quiescent state. Stem cells. 2007 Jul;25(7):1753-60. PubMed PMID: 17395776.

136. Ramasamy R, Lam EW, Soeiro I, Tisato V, Bonnet D, Dazzi F. Mesenchymal stem cells inhibit proliferation and apoptosis of tumor cells: impact on in vivo tumor growth. Leukemia. 2007 Feb;21(2):304-10. PubMed PMID: 17170725.

137. Khubutiya MS, Vagabov AV, Temnov AA, Sklifas AN. Paracrine mechanisms of proliferative, anti-apoptotic and anti-inflammatory effects of mesenchymal stromal cells in models of acute organ injury. Cytotherapy. 2013 Oct 8. PubMed PMID: 24113425.

138. Danial NN, Korsmeyer SJ. Cell death: critical control points. Cell. 2004 Jan 23;116(2):20519. PubMed PMID: 14744432.

139. Hofmeister R, Khaled AR, Benbernou N, Rajnavolgyi E, Muegge K, Durum SK. Interleukin7: physiological roles and mechanisms of action. Cytokine \& growth factor reviews. 1999 Mar;10(1):41-60. PubMed PMID: 10379911.

140. Al-Rawi MA, Mansel RE, Jiang WG. Interleukin-7 (IL-7) and IL-7 receptor (IL-7R) signalling complex in human solid tumours. Histology and histopathology. 2003 Jul;18(3):911-23. PubMed PMID: 12792903.

141. De Miguel MP, Fuentes-Julian S, Blazquez-Martinez A, Pascual CY, Aller MA, Arias J, et al. Immunosuppressive properties of mesenchymal stem cells: advances and applications. Current molecular medicine. 2012 Jun;12(5):574-91. PubMed PMID: 22515979. 